FACULDADE DE FILOSOFIA, CIÊNCIAS E LETRAS DE RIBEIRÃO PRETO PROGRAMA DE PÓS-GRADUAÇÃO EM BIOLOGIA COMPARADA

\title{
Uma abordagem molecular do papel de ionotransportadores branquiais na regulação osmótica e iônica de crustáceos hololimnéticos de água doce
}

\author{
Milene Mantovani Mata
}

Tese apresentada à Faculdade de Filosofia, Ciências e Letras de Ribeirão Preto da Universidade de São Paulo, como parte das exigências para obtenção do título de Doutor em Ciências, obtido no Programa de Pós-Graduação em Biologia Comparada

Ribeirão Preto - SP 
UNIVERSIDADE DE SÃO PAULO

FACULDADE DE FILOSOFIA, CIÊNCIAS E LETRAS DE RIBEIRÃO PRETO PROGRAMA DE PÓS-GRADUAÇÃO EM BIOLOGIA COMPARADA

\title{
Uma abordagem molecular do papel de ionotransportadores branquiais na regulação osmótica e iônica de crustáceos hololimnéticos de água doce
}

\author{
Milene Mantovani Mata
}

Tese apresentada à Faculdade de Filosofia, Ciências e Letras de Ribeirão Preto da Universidade de São Paulo, como parte das exigências para obtenção do título de Doutor em Ciências, obtido no Programa de Pós-Graduação em Biologia Comparada

Orientador: Prof. Dr. John Campbell McNamara Versão corrigida

Ribeirão Preto - SP 
Autorizo a reprodução e divulgação total ou parcial deste trabalho, por qualquer meio convencional ou eletrônico, para fins de estudo e pesquisa, desde que citada a fonte.

\section{Mantovani, Milene Mata}

Uma abordagem molecular do papel de ionotransportadores branquiais na regulação osmótica e iônica de crustáceos hololimnéticos de água doce

$$
110 \text { p. : il. }
$$

Tese de Doutorado apresentada ao Departamento de Biologia da Faculdade de Filosofia, Ciências e Letras de Ribeirão Preto/USP, 2019. Área de concentração: Biologia Comparada.

Orientador: McNamara, John Campbell.

1. Osmorregulação. 2. Regulação iônica. 3. Hiper-osmorregulação. 4. Hipoosmorregulação. 5. Brânquias. 6. Ionotransportadores. 7. Expressão gênica. 8. Expressão proteica. 9. Crustacea, Decapoda. 10. Brachyura. 11. Palaemonidae. 


\section{FOLHA DE APROVAÇÃO}

Milene Mantovani Mata

Uma abordagem molecular do papel de ionotransportadores branquiais na regulação osmótica e iônica de crustáceos hololimnéticos de água doce

Tese apresentada à Faculdade de Filosofia, Ciências e Letras de Ribeirão Preto da USP, como parte das exigências para a obtenção do título de Doutor em Ciências, Área: Biologia Comparada

Aprovada em:

\section{Banca examinadora}

Prof. Dr.

Instituição Assinatura

Prof. Dr.

Instituição Assinatura

Prof. Dr.

Instituição Assinatura

Prof. Dr.

Instituição Assinatura

Prof. Dr. Instituição Assinatura 


\section{DEDICATÓRIA}

Aos meus pais, Irineu e Claudinéa, pelo amor e oportunidade. Aos meus irmãos, Élder e Liliane, por serem pilares de sustentação. Ao meu amado companheiro, Leandro, por ser porto seguro. Ao meu mestre, John McNamara, pela motivação. 


\section{AGRADECIMENTOS}

\section{A realização deste trabalho só foi possível com a ajuda de importantes instituições e de pessoas queridas, incluindo profisssionais, amigos e familiares. A vocês, minha eterna gratidão!}

Agradeço aos meus pais, Irineu e Claudinéa, por sempre terem me proporcionado a oportunidade de estudar e colocarem a educação como o bem mais importante. Agradeço também por serem o meu maior exemplo de luta, perseverança e resiliência.

Agradeço ao meu querido orientador e professor, John McNamara, por ter acreditado em mim desde sempre! Agradeço pela oportunidade, exemplo e companheirismo em todos os momentos do desenvolvimento desse trabalho. Agradeço por todos os ensinamentos acadêmicos, científicos e pessoais. Sem o seu apoio e compreensão, jamais eu teria feito esse trabalho.

Agradeço ao Programa de Pós-Graduação em Biologia Comparada, professores, colegas e funcionários, pela dedicação, formação, convivência, recursos financeiros e hospitalidade.

Agradeço à FAPESP e ao $\mathrm{CNPq}$ pelo recurso disponibilizado para o desenvolvimento do projeto.

Agradeço às equipes da Fazenda São Geraldo e Clube Náutico, por terem permitido e facilitado a coleta dos caranguejos e camarões, respectivamente.

A todos os meus amigos do Laboratório de Fisiologia de Crustáceos: à técnica Susie, por toda a ajuda com os experimentos, manutenção dos bichos, pela paciência e dedicação; à Aniele Maraschi (Ani), por me ajudar em coletas e sempre me ensinar questões relacionadas à manutenção dos animais, experimentos de bancada, teorias, além de questões pessoais e de amizade; Rogério Faleiros, por ter me apoiado a fazer parte do laboratório, por me ajudar com as coletas iniciais, por me ensinar coisas sobre a organização e metodologia do laboratório, por discutir resultados e teorias e também pela amizade; Mariana Capparelli pela ajuda em muitas coletas e dosagens, além da grande companhia e amizade.

Aos meus estimados chefes professores Dr. José Antunes e Dr. ${ }^{a}$ Lucila Elias, pelo incentivo, apoio e compreensão na realização desse doutorado, além do empréstimo do aparelho de PCR em tempo real, dos aparatos de western blotting e, muitas vezes, do espaço 
físico do Laboratório de Neuroendocrinologia - FMRP. Para mim, vocês são exemplos não só profissionais, e com certeza tornam o meu dia-a-dia mais feliz!

Aos meus amigos do Laboratório de Neuroendocrinologia, também pelo incentivo, compreensão e ajuda.

A todos meus familiares e amigos que de alguma forma me apoiaram nessa jornada acadêmica e que contribuem para que a minha caminhada da vida seja repleta de realizações, satisfação e paz.

Em especial, agradeço ao meu irmão, Élder, por ser referência e conforto em todos os momentos, inclusive nos que ainda virão!

E, finalmente, agradeço ao meu muito amado companheiro, Leandro, por ter sido também meu parceiro de coleta e maior incentivador para que eu realizasse esse trabalho. A família que formamos junto com a Maitê é a minha maior fonte de energia, paz e alegria! 


\section{RESUMO}

Pela sua diversidade e por ocuparem a maioria dos habitats disponíveis no planeta, o grupo dos crustáceos é ideal para a reconstrução da história evolutiva da osmorregulação. As espécies de meios diluídos ou de água doce enfrentam intenso influxo osmótico de água e perda de sal pela superfície corporal, minimizados por poderosos mecanismos de hiperosmorregulação. Os principais processos que atuam na homeostase osmótica e iônica são a Regulação Isosmótica Intracelular (RII) e, particularmente, a Regulação Anisosmótica Extracelular (RAE). Na RII, a composição e o volume do fluido intracelular são conservados, devido ao transporte de íons pelo simportador $\mathrm{Na}^{+} / \mathrm{K}^{+} / 2 \mathrm{Cl}^{-}$e pela $\mathrm{Na}^{+} / \mathrm{K}^{+}$-ATPase, e principalmente pela síntese e/ou degradação de aminoácidos e peptídeos. Na RAE, a osmolalidade, a concentração iônica e o volume do fluido extracelular ou hemolinfa são mantidos próximos àqueles do fluido intracelular, pela atuação das proteínas ionotransportadoras $\mathrm{Na}^{+} / \mathrm{K}^{+}$-ATPase e $\mathrm{V}\left(\mathrm{H}^{+}\right)$-ATPase, do simportador $\mathrm{Na}^{+} / \mathrm{K}^{+} / 2 \mathrm{Cl}^{-}$e canais iônicos, que participam da captura e reabsorção de sal em meio hiposmótico, como a água doce, e da secreção de sal em meio hiperosmótico. Estas proteínas estão localizadas em células branquiais altamente diferenciadas, denominadas ionócitos. O presente trabalho buscará avaliar a regulação osmótica e iônica em nível sistêmico e molecular, utilizando dois crustáceos hololimnéticos de água doce, frente a desafios osmóticos e iônicos. Selecionamos espécies filogeneticamente distantes, o caranguejo braquiúro Dilocarcinus pagei e o camarão carídeo Macrobrachium jelskii, a fim de avaliar seus mecanismos osmorregulatórios, e se estes permitiram a ocupação de água doce em eventos independentes. Espécimes de D. pagei foram coletados em riachos de Sertãozinho, região nordeste do estado de São Paulo, Brasil. Após aclimatização em laboratório, os caranguejos foram submersos em água destilada (0 $\left.\%_{0} \mathrm{~S}\right)$ ou salobra $(25 \% \mathrm{~S})$, constituindo desafios hipo- ou hiper-osmóticos, respectivamente, por tempos determinados de até 10 dias. Parâmetros sistêmicos como a osmolalidade, a $\left[\mathrm{Na}^{+}\right]$ e a $\left[\mathrm{Cl}^{-}\right]$da hemolinfa foram avaliados, sendo observado aumento ao longo do decurso temporal em água a $25 \% \mathrm{~S}$. Em água destilada, obtivemos resultados inéditos, com pequeno aumento da osmolalidade apenas nos momentos iniciais de exposição, sem variações na $\left[\mathrm{Cl}^{-}\right]$ e com diminuição da $\left[\mathrm{Na}^{+}\right]$da hemolinfa após 24 horas. Parâmetros moleculares, como a expressão gênica dos ionotransportadores $\mathrm{Na}^{+} / \mathrm{K}^{+}$-ATPase, $\mathrm{V}\left(\mathrm{H}^{+}\right)$-ATPase e $\mathrm{Na}^{+} / \mathrm{K}^{+} / 2 \mathrm{Cl}^{-}$, mostraram diminuição em água a $25 \% \mathrm{~S}$. Em água destilada, houve diminuição da expressão gênica da $\mathrm{Na}^{+} / \mathrm{K}^{+}$-ATPase a partir de $24 \mathrm{~h}$ de exposição. Os exemplares de $M$. jelskii foram coletados na via fluvial do Clube Náutico de Araraquara, região central do estado de São Paulo, Brasil. Após aclimatização em laboratório, os camarões foram submersos em água destilada $(0 \% \mathrm{~S})$ ou salobra $(20 \% \mathrm{~S})$, por tempos determinados de até 12 horas ou 10 dias, respectivamente. Parâmetros sistêmicos (osmolalidade, $\left[\mathrm{Na}^{+}\right]$e $\left[\mathrm{Cl}^{-}\right]$da hemolinfa) aumentaram ao longo do decurso temporal em água a $20 \% \mathrm{~S}$. Em água destilada, houve diminuição desses parâmetros até o tempo de 12 horas, a partir do qual os camarões não sobreviveram. Parâmetros moleculares revelaram aumento da expressão gênica das proteínas $\mathrm{Na}^{+} / \mathrm{K}^{+}$-ATPase, $\mathrm{V}\left(\mathrm{H}^{+}\right)$-ATPase e $\mathrm{Na}^{+} / \mathrm{K}^{+} / 2 \mathrm{Cl}^{-}$em água a $20 \% \mathrm{~S}$. Em água destilada, a expressão gênica da $\mathrm{V}\left(\mathrm{H}^{+}\right)$-ATPase e do simportador $\mathrm{Na}^{+} / \mathrm{K}^{+} / 2 \mathrm{Cl}^{-}$também aumentou até 12 horas. Ainda, análises de expressão proteica para $\mathrm{Na}^{+} / \mathrm{K}^{+}$-ATPase e $\mathrm{Na}^{+} / \mathrm{K}^{+} / 2 \mathrm{Cl}^{-}$foram realizadas, mas os resultados não apresentaram forte correlação com as respectivas expressões gênicas. Para ambas as espécies, construímos fenogramas com as sequências parciais das regiões codificadoras das proteínas de interesse, que nos revelaram informações sobre a evolução de suas sequências gênicas. Os dados apresentados aumentam o conhecimento acerca da fisiologia e biologia molecular dos mecanismos osmorregulatórios em D. pagei e $M$. jelskii, duas espécies muito distantes que habitam o mesmo biótopo, revelando respostas 
divergentes quanto ao enfrentamento de desafios osmóticos semelhantes. O conjunto de dados e suas análises contribuem para um melhor entendimento dos processos que levaram à ocupação da água doce pelos crustáceos decápodes. 


\begin{abstract}
Because of their diversity, and since they occupy most of the habitats available on the planet, the crustaceans are ideal for reconstructing the evolutionary history of osmoregulation. Species that live in dilute or freshwater media face intense osmotic influx of water and loss of salt across the body surfaces, minimized by powerful mechanisms of hyper-osmoregulation, The main processes that underlie osmotic and ionic homeostasis are Isosmotic Intracellular Regulation (IIR) and, in particular, Anisosmotic Extracellular Regulation (AER). In IIR, the composition and volume of the intracellular fluid are conserved, due to ion transport by the $\mathrm{Na}^{+} / \mathrm{K}^{+} / 2 \mathrm{Cl}^{-}$symporter and $\mathrm{Na}^{+} / \mathrm{K}^{+}$-ATPase, and by the synthesis and/or degradation of amino acids and peptides. In AER, the osmolality, ionic concentration and volume of the extracellular fluid or hemolymph are kept close to those of the intracellular fluid, by the action of ionotransporter proteins such as the $\mathrm{Na}^{+} / \mathrm{K}^{+}$-ATPase and $\mathrm{V}\left(\mathrm{H}^{+}\right)$-ATPase, the $\mathrm{Na}^{+} / \mathrm{K}^{+} / 2 \mathrm{Cl}^{-}$symporter and ion channels, which enable the capture and resorption of salt in hyposmotic medium, such as fresh water, and salt secretion in hyperosmotic medium. These membrane proteins are located in highly differentiated gill cells, known as ionocytes. The present study will seek to appreciate osmotic and ionic regulation at the systemic and molecular levels, using two freshwater hololimnetic crustaceans exposed to osmotic and ionic challenges. We selected phylogenetically distant species, the brachyuran crab Dilocarcinus pagei and the caridean shrimp Macrobrachium jelskii, in order to evaluate their osmoregulatory mechanisms, and whether these have allowed the occupation of fresh water through independent events. Specimens of D. pagei were collected in streams near Sertãozinho in the northeast region of the State of São Paulo, Brazil. After acclimatization in the laboratory, the crabs were maintained submerged in distilled $(0 \%$ salinity $[\% 0 \mathrm{~S}])$ or brackish water $(25 \% \mathrm{~S})$, constituting hypo- or hyperosmotic challenges, respectively, for up to 10 days. Systemic parameters such as the osmolality, $\left[\mathrm{Na}^{+}\right]$and $\left[\mathrm{Cl}^{-}\right]$of the hemolymph were evaluated, and showed an increase over the time in medium of $25 \% \mathrm{~S}$. In distilled water, we obtained novel results, showing a small increase in hemolymph osmolality during the initial exposure times, with no change in $\left[\mathrm{Cl}^{-}\right]$, and a decrease in hemolymph $\left[\mathrm{Na}^{+}\right]$after 24 hours. Molecular parameters such as the gene expression of the $\mathrm{Na}^{+} / \mathrm{K}^{+}$-ATPase, $\mathrm{V}\left(\mathrm{H}^{+}\right)$ATPase and the $\mathrm{Na}^{+} / \mathrm{K}^{+} / 2 \mathrm{Cl}^{-}$decreased when in medium of $25 \% \mathrm{~S}$. In distilled water, $\mathrm{Na}^{+} / \mathrm{K}^{+}-$ ATPase gene expression decreased after $24 \mathrm{~h}$ exposure. Specimens of the M. jelskii were collected at the Clube Náutico de Araraquara, in the central region of the State of São Paulo, Brazil. After acclimatization in the laboratory, the shrimps were submerged in distilled (0 $\% \mathrm{~S})$ or brackish water $(20 \% \mathrm{~S})$, for up to 12 hours or 10 days, respectively. Systemic parameters (hemolymph osmolality, $\left[\mathrm{Na}^{+}\right]$and $\left[\mathrm{Cl}^{-}\right]$) increased with exposure time in medium of $20 \% \mathrm{~S}$. In distilled water, these parameters decreased up to 12 hours, after which the shrimps did not survive. Molecular parameters revealed increased gene expression of the $\mathrm{Na}^{+} / \mathrm{K}^{+}$-ATPase, $\mathrm{V}\left(\mathrm{H}^{+}\right)$-ATPase and the $\mathrm{Na}^{+} / \mathrm{K}^{+} / 2 \mathrm{Cl}^{-}$ionotransporter proteins in medium of $20 \% \mathrm{~S}$. In distilled water, the gene expression of $\mathrm{V}\left(\mathrm{H}^{+}\right)$-ATPase and the $\mathrm{Na}^{+} / \mathrm{K}^{+} / 2 \mathrm{Cl}^{-}$ symporter also increased up to 12 hours. Further, protein expression analyses for the $\mathrm{Na}^{+} / \mathrm{K}^{+}-$ ATPase and the $\mathrm{Na}^{+} / \mathrm{K}^{+} / 2 \mathrm{Cl}^{-}$did not show a strong correlation with their respective gene expressions. For both species, we constructed phenograms with the partial cDNA sequences of the coding regions of the proteins of interest, which revealed useful information of the evolution of their gene sequences. The data presented increase our knowledge of the physiology and molecular biology of osmoregulatory mechanisms in D. pagei and M. jelskii, two very distant species that inhabit the same biotope, revealing divergent responses to similar osmotic challenges. The datasets obtained and their analyses contribute to a better understanding of the processes that have led to the occupation of fresh water by the decapod Crustacea.
\end{abstract}




\section{SUMÁRIO}

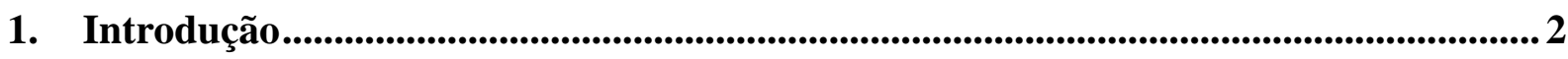

1.1 O caranguejo vermelho de água doce, Dilocarcinus pagei ........................................ 9

1.2 O camarão sossego de água doce, Macrobrachium jelskii .......................................... 11

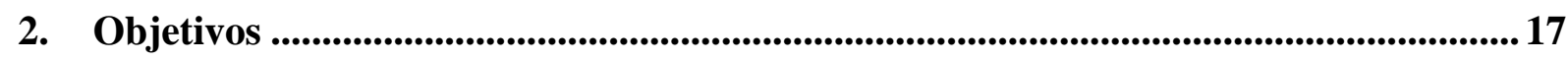

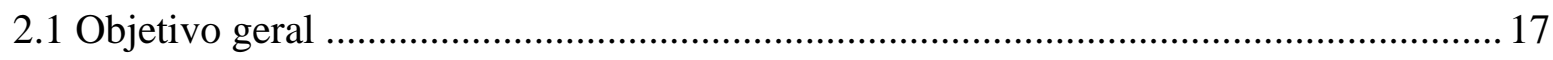

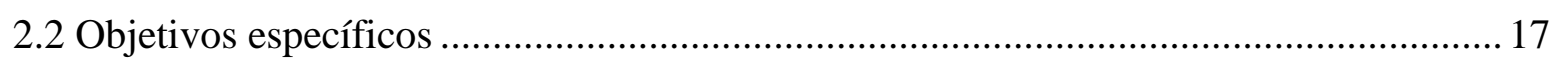

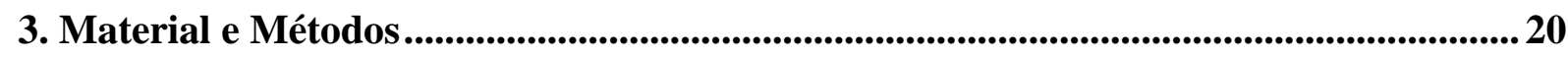

3.1 Metodologia específica para o caranguejo Dilocarcinus pagei ...................................... 20

3.1.1 Coleta, manutenção e aclimatação dos animais em diferentes salinidades....... 20

3.1.2 Medidas de osmolalidade e das concentrações de $\mathrm{Cl}^{-} \mathrm{e} \mathrm{Na}^{+}$............................ 21

3.1.3 Dissecção das brânquias.............................................................................. 21

3.2 Metodologia específica para o camarão Macrobrachium jelskii .................................... 22

3.2.1 Coleta, manutenção e aclimatação dos animais em diferentes salinidades....... 22

3.2.2 Mortalidade e determinação do limite letal superior de salinidade ( $\left.\operatorname{LSS}_{50}\right)$ para Macrobrachium jelskii .................................................................................... 23

3.2.3 Medidas de osmolalidade e das concentrações de $\mathrm{Cl}^{-}$e $\mathrm{Na}^{+}$........................... 23

3.2.4 Dissecção das brânquias........................................................................... 24

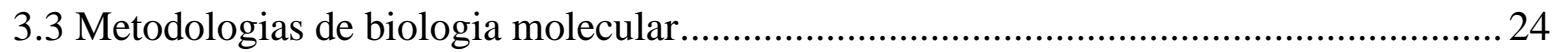

3.3.1 Purificação e quantificação de RNA total ........................................................ 24

3.3.2 Transcrição reversa dos mRNAs - produção de cDNA .................................... 27

3.3.3 Clonagem e sequenciamento dos cDNAs de interesse .................................... 29

3.3.4 Análises quantitativas por PCR em tempo real (qPCR).................................. 46

3.3.5 Análise de expressão protéica por western blotting ....................................... 50

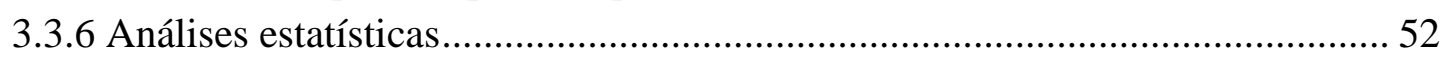

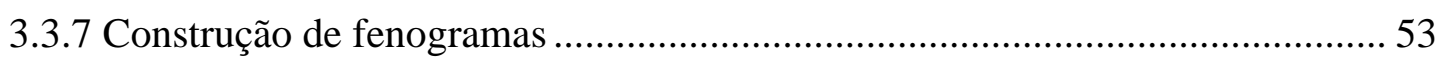

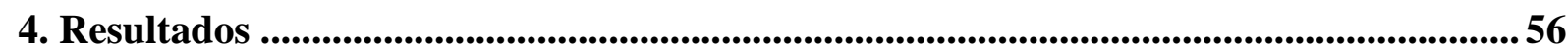

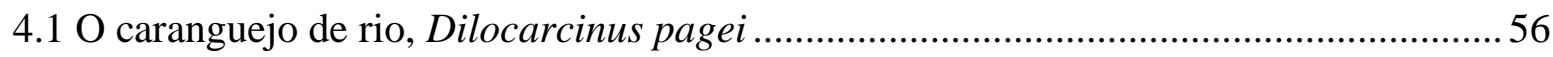

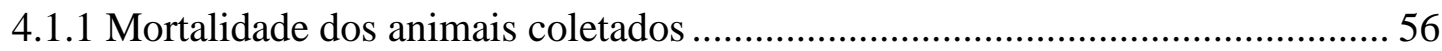

4.1.2 Decurso temporal de osmolalidade, $\left[\mathrm{Cl}^{-}\right]$e $\left[\mathrm{Na}^{+}\right]$durante desafio hiper- ou

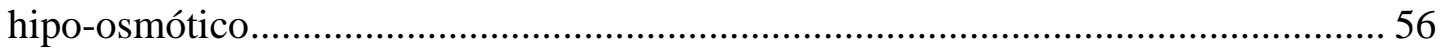

4.1.3 Análises das expressões dos ionotransportadores por qPCR em brânquias de $D$.

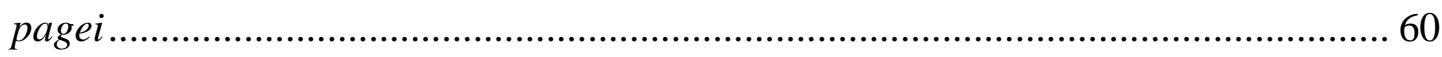

4.1.4 Expressão proteica do ionotransportador $\mathrm{Na}^{+} / \mathrm{K}^{+}$-ATPase em brânquias de $D$. pagei. 
4.1.5 Correlação entre as expressões gênica e proteica do ionotransportador $\mathrm{Na}^{+} / \mathrm{K}^{+}$ATPase em brânquias de D. pagei .

4.2.1 Mortalidade dos animais coletados

4.2.2 Determinação do desafio hiperosmótico a partir do limite letal superior de salinidade $\left(\mathrm{LSS}_{50}\right)$

4.2.3 Decurso temporal de osmolalidade, $\left[\mathrm{Cl}^{-}\right]$e $\left[\mathrm{Na}^{+}\right]$da hemolinfa 67

4.2.4 Análises das expressões dos ionotransportadores por qPCR em brânquias de $M$. jelskii 71

4.2.5 Quantificação da expressão proteica em brânquias de $M$. jelskii ...................... 75

4.2.6 Correlação entre as expressões gênica e proteica de $M$. jelskii....................... 76

4.3 Incluindo o fator espécie (Dilocarcinus pagei e Macrobrachium jelskii) nas análises estatísticas

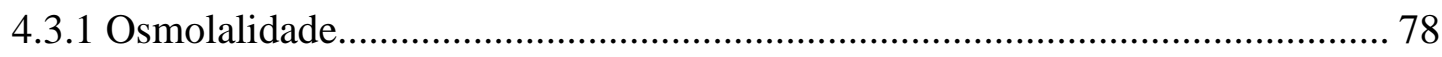

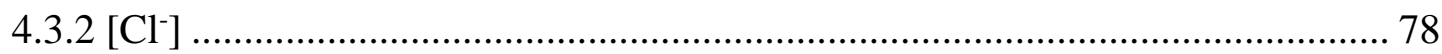

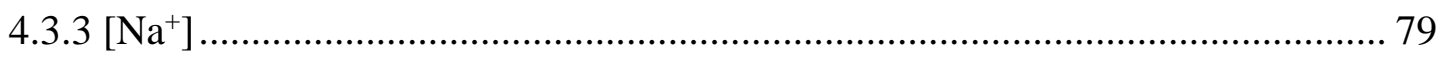

4.3.4 Expressão gênica da subunidade $\mathrm{B}$ da $\mathrm{V}\left(\mathrm{H}^{+}\right)$-ATPase .................................... 79

4.3.5 Expressão gênica da subunidade $\alpha \mathrm{da} \mathrm{Na}^{+} / \mathrm{K}^{+}$-ATPase ................................... 79

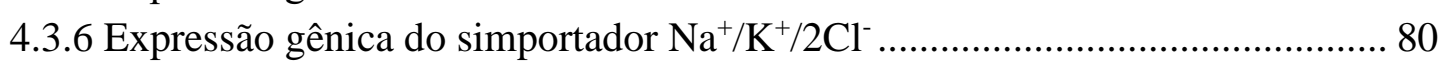

\section{Discussão}

5.1 Osmorregulação em Dilocarcinus pagei e Macrobrachium jelskii: do sistêmico ao molecular

5.1.1 Dilocarcinus pagei.

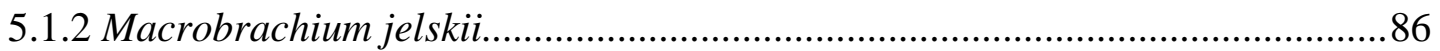

5.2 Análise geral de expressão proteica e sua correlação com a expressão gênica .............. 90

5.3 Comparação entre as respostas das duas espécies: a inclusão do fator 'espécie' nas análises estatísticas

5.4 Análise fenotípica das sequências de DNA obtidas para os ionotransportadores de interesse

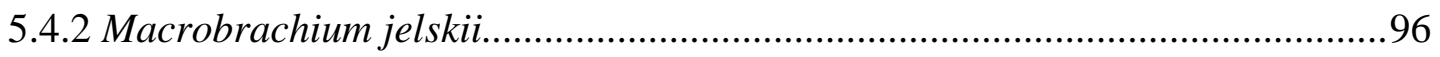

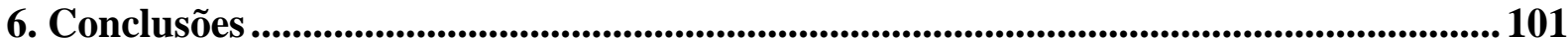

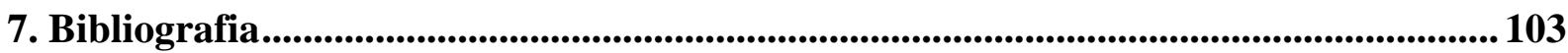


Introdução 


\section{Introdução}

A ocupação dos ambientes terrestres ou aquáticos, marinhos ou dulcícolas, está associada à interação fisiológica dos organismos com os fatores bióticos e abióticos presentes, constituindo um processo determinante na invasão e ocupação de um habitat (Begon et al., 2007; Faria et al., 2017). A água é um componente fundamental dos fluidos corporais, tanto os intra como os extracelulares, e o seu movimento osmótico entre este meio interno e o meio externo, seja de maneira obrigatória ou de forma regulada, representa um desafio aos organismos. A concentração iônica de um fluido determina a intensidade e a direção do fluxo dos íons e da água dentro e fora do compartimento que o contém (Péqueux, 1995; SchmidtNielsen, 2002; Willmer et al., 2005; McNamara \& Faria, 2012), sendo a homeostase hidroeletrolítica, portanto, um dos determinantes fisiológicos do potencial de diversificação de nichos.

Águas salobras e a água doce começaram a ser invadidas por alguns taxons como os caranguejos tricodactilídeos, potamóideos e grapsídeos e camarões carídeos. Isso ocorreu em tempos geológicos diferentes, relacionados a inúmeras mudanças nos oceanos, separações de massas de terra e eventos de glaciações (Augusto et al., 2007b; Collins et al., 2011; Klaus et al., 2011; Ashelby et al., 2012; Freire et al., 2013), pois os clados maiores e mais inclusivos dos decápodes possuem ancestrais originalmente marinhos (Ruppert \& Barnes, 1994; Freire et $a l .$, 2013). Sendo assim, a ocupação de ambientes mais diluídos pelos crustáceos gerou vários graus de capacidade osmorregulatória, em contraste ao comportamento típico de osmoconformação das espécies marinhas (Péqueux, 1995; Freire et al., 2003; Augusto et al., 2007a,b; Charmantier et al., 2009; Lee et al., 2012; McNamara \& Faria, 2012). Os crustáceos tiveram bastante sucesso nesse movimento evolutivo (Ashelby et al., 2012; McNamara \& Faria, 2012). As prováveis razões são a presença do espaço subcuticular, a redução da permeabilidade epitelial (Kirschner, 1991; Péqueux, 1995; Charmantier et al., 2009; Ashelby et al., 2012) e a regulação do volume intra e extracelular (Péqueux, 1995; Augusto et al., 2007a, b; Freire et al., 2008b).

Uma vez que os crustáceos decápodes ocupam a maioria dos habitats disponíveis em nosso planeta, esses animais formam um grupo ideal para a reconstrução da história evolutiva da osmorregulação. Enquanto a maioria dos crustáceos decápodes marinhos não mantém um gradiente osmótico significativo entre seu fluido extracelular e a água do mar (33 g de sal/L $[\% \mathrm{~S}])$, ou seja, são isosmóticos, representantes do entre-marés e estuários exibem 
capacidades hiper e/ou hiporregulatórias diferenciais, mantendo a concentração do fluido extracelular acima ou abaixo daquela do meio circundante (Péqueux, 1995; Freire et al., 2008b), sendo, portanto, hiper- ou hipo-osmorreguladores, respectivamente. As espécies que habitam meios bastante diluídos ou a água doce $(<0,5 \mathrm{~g}$ de sal/L $[\% \mathrm{~S}])$ enfrentam intenso influxo osmótico de água e perda de sal pela superfície corporal e urina, compensados por poderosos mecanismos de hiper-regulação, como a captura ativa de sal (Onken et al., 1995; Weihrauch et al., 2004; Freire et al., 2008a), além de produzirem uma urina volumosa, frequentemente diluída. Essas capacidades, junto com a redução da permeabilidade à água, constituem importantes adaptações morfológicas e fisiológicas que, provavelmente, subsidiaram a ocupação de meios mais diluídos pelos crustáceos (Mantel \& Farmer, 1983; Péqueux, 1995). Dessa forma, crustáceos de água doce são resistentes a esse desafio osmótico severo, sendo caracterizados como hiper-reguladores fortes, pois estabelecem gradientes osmótico e iônico elevados contra o meio externo $(\approx 30: 1)$.

Tanto em crustáceos osmoconformadores, os quais mantêm a osmolalidade semelhante ao meio externo em determinada salinidade, como em osmorreguladores, há dois principais processos que atuam na homeostase osmótica e iônica:

(i) A Regulação Isosmótica Intracelular (RII), que conserva a composição e o volume intracelular (Péqueux, 1995), mediada pelo transporte de íons como $\mathrm{Na}^{+}, \mathrm{K}^{+}$e $\mathrm{Cl}^{-}$pelo simportador $\mathrm{Na}^{+} / \mathrm{K}^{+} / 2 \mathrm{Cl}^{-}$e pela $\mathrm{Na}^{+} / \mathrm{K}^{+}$-ATPase (Freire et al., 2013), e pela síntese e/ou degradação de aminoácidos e peptídeos, reduzindo ou aumentando a osmolalidade intracelular. A estabilidade da osmolalidade do fluido intracelular tampona a composição e o volume citosólico, limitando a exposição da maquinaria celular a variações nesse meio metabolicamente importante para o funcionamento celular (Augusto et al., 2007b). Vale ressaltar que os fluidos intracelulares são sempre isosmóticos em relação ao fluido extracelular, pois as células regulam seu volume visando manter/alcançar tal isosmoticidade (Péqueux, 1995; Freire et al., 2008a). Este é o principal processo osmorregulatório dos crustáceos conformadores.

(ii) A Regulação Anisosmótica Extracelular (RAE), que mantém a osmolalidade, a concentração iônica e o volume da hemolinfa próximos àqueles do fluido intracelular. Atuantes nesse processo estão as proteínas ionotransportadoras $\mathrm{Na}^{+} / \mathrm{K}^{+}$-ATPase e $\mathrm{V}\left(\mathrm{H}^{+}\right)$ATPase (Towle \& Kays, 1986; Tsai \& Lin, 2007), simportadores como a $\mathrm{Na}^{+} / \mathrm{K}^{+} / 2 \mathrm{Cl}^{-}$e canais iônicos, todos localizados nos ionócitos do epitélio das brânquias (Péqueux, 1995; Freire et al., 2008a), glândulas antenais e intestino. Tais proteínas permitem a captura ou reabsorção de sal em meio hiposmótico e a secreção de sal em meio hiperosmótico (Péqueux, 1995; Freire et 
al., 2008a; Faleiros et al., 2010; McNamara \& Faria, 2012; McNamara et al., 2015). Esse mecanismo predomina nos crustáceos osmorreguladores.

Conforme os mecanismos homeostáticos extracelulares evoluíram, as pressões seletivas sobre os mecanismos da RII possivelmente foram reduzidas, diminuindo essa regulação depois de muito tempo de evolução em água doce (Augusto et al., 2007a, b; Freire et al., 2008b). Os osmoconformadores eurialinos (que suportam largas faixas de variação de salinidade) dependem inteiramente da RII, enquanto os osmorreguladores fortes (espécies de água doce) mostram menor dependência desses mecanismos, já que empregam ações regulatórias exercidas pela interface de epitélios, como as brânquias e órgãos excretores, para manutenção de um meio extracelular mais constante ou estável (Péqueux, 1995; Foster et al., 2010) em relação ao meio circundante. Além disso, vale destacar que há crustáceos que regulam parcialmente em uma faixa de salinidade, mas conformam em outra, sendo denominados 'intermediários’ (Péqueux, 1995, Mantel \& Farmer, 1983).

As brânquias dos crustáceos são o principal local de trocas iônicas e gasosas. Constituem uma superfície amplificada, diferencialmente permeável ao fluxo de gases, íons e água, entre o meio externo e o fluido extracelular. O número de pares de brânquias varia entre os decápodes e, dependendo do lugar de inserção no corpo do animal, podem ser distinguidas em pleurobrânquia (ligada à pleura), artrobrânquia (ligada à articulação entre a pleura e a coxa dos apêndices locomotores) e podobrânquia (ligada à base dos apêndices anteriores). O tipo de amplificação da área de superfície das brânquias também pode diferir, sendo que as filobrânquias são constituídas de lamelas achatadas e são o tipo encontrado na maioria dos braquiúros, alguns anomuros, galatheídeos e camarões carídeos. Na maioria dos braquiúros, as brânquias são diferenciadas, sendo as brânquias anteriores responsáveis pelas trocas gasosas e as posteriores, pelas trocas iônicas. Nas filobrânquias dos braquiúros as lamelas ficam dispostas em ambos os lados de um eixo central, que contém um vaso aferente e outro eferente, localizados em pólos opostos do eixo central da brânquia (Figura 1A) (Onken \& McNamara, 2002). Já nos camarões carídeos, as filobrânquias estão dispostas como uma série de lamelas planas bi-seriadas inseridas no eixo central da brânquia. Este eixo é perfundido por três vasos sanguíneos, um vaso central aferente e dois vasos laterais eferentes (Figura 1B). Células pilares dentro das lamelas definem canais de hemolinfa que se curvam e se conectam a um canal marginal, o qual corre em toda a periferia da lamela (Freire \& McNamara, 1995). As tricobrânquias são encontradas em Anomura de água doce, Parastacidae e Palinura. O eixo central sustenta numerosos filamentos tubulares não ramificados. As brânquias são bilateralmente simétricas e os filamentos estão dispostos em fileiras (Figura 1C). As 
dendobrânquias ocorrem em camarões peneídeos e sergestídeos. O eixo central das brânquias sustenta lâminas bi-seriais secundárias, que se curvam e se encontram na ponta. Filamentos terciários se projetam dessas lâminas e se bifurcam (Figura 1D) (Freire et al., 2008a).
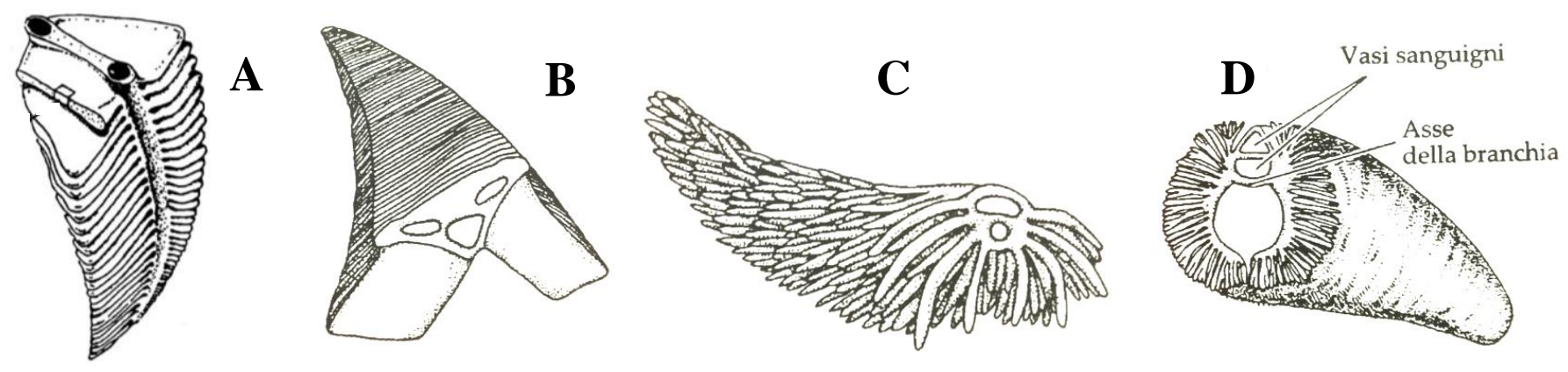

Figura 1. Esquemas representativos dos tipos morfológicos de brânquias de crustáceos decápodes. A) Filobrânquia de caranguejos braquiúros (Onken \& Riestenpatt, 1998); B) Filobrânquia de camarões carídeos; C) Tricobrânquia; D) Dendobrânquia (Brusca \& Brusca, 2013).

Apesar das diferenças morfológicas, as brânquias dos decápodes estão envolvidas nos mesmos processos fisiológicos: trocas gasosas, equilíbrio ácido-base, excreção de produtos metabólicos nitrogenados e captura e/ou secreção de íons. Os ionócitos são as células branquiais responsáveis pelo transporte de íons, com membrana plasmática elaborada, amplificada por evaginações apicais, bem como de extensas e profundas invaginações basais, intimamente associadas a um elevado número de mitocôndrias (Freire \& McNamara, 1995; McNamara \& Lima, 1997; Onken \& McNamara, 2002; Weihrauch et al., 2004; Furriel et al., 2010; McNamara \& Faria, 2012; McNamara et al., 2015). A ATPase mitocondrial $\mathrm{F}_{\mathrm{o}} \mathrm{F}_{1}$ fornece aos ionócitos o ATP para os transportadores iônicos envolvidos na captura ou secreção ativa de sal como a $\mathrm{Na}^{+} / \mathrm{K}^{+}$- e a $\mathrm{V}\left(\mathrm{H}^{+}\right)$-ATPase (Weihrauch et al., 2004).

Os diferentes padrões e processos osmorregulatórios decorrem de diferentes arranjos de transportadores presentes no epitélio branquial de representantes de diferentes ambientes e linhagens, desde osmoconformadores marinhos, hiper-/hipo-osmorreguladores de ambientes costeiros, do entre-marés ou estuarinos, até espécies hiper-osmorreguladoras dulcícolas e semi-terrestres (McNamara \& Faria, 2012). No que se refere a espécies dulcícolas, o mecanismo de hiper-osmorregulação é melhor entendido no grupo dos crustáceos decápodes braquiúros de epitélios pouco permeáveis ou de alta resistência (Péqueux, 1995; Kirschner, 2004; Freire et al., 2008a; McNamara \& Faria 2012). Na captura de $\mathrm{Na}^{+} \mathrm{e} \mathrm{Cl}^{-}$da água doce pelas brânquias desses reguladores (Figura 2), mais especificamente nos ionócitos, a enzima anidrase carbônica citosólica hidrata o $\mathrm{CO}_{2}$ metabólico, gerando os íons $\mathrm{H}^{+}$e $\mathrm{HCO}_{3}^{-}$que 
sustentam a atividade da $\mathrm{V}\left(\mathrm{H}^{+}\right)$-ATPase e do antiportador $\mathrm{Cl}^{-} / \mathrm{HCO}_{3}{ }^{-}$apicais (Kirschner, 2004; Freire et al., 2008a; McNamara \& Faria, 2012). A V( $\left.\mathrm{H}^{+}\right)$-ATPase, ao descarregar $\mathrm{H}^{+}$ ativamente pela membrana apical, hiperpolariza esta membrana e o citoplasma, criando um potencial positivo extracelular, que promove a entrada de $\mathrm{Na}^{+}$via canais $\mathrm{de} \mathrm{Na}^{+}$apicais ao longo do seu gradiente eletroquímico. $\mathrm{O}$ acúmulo de $\mathrm{HCO}_{3}{ }^{-}$promove a absorção de $\mathrm{Cl}^{-}$ através do trocador apical $\mathrm{Cl}^{-} / \mathrm{HCO}_{3}{ }^{-}$, e o potencial negativo intracelular dirige a saída $\mathrm{de}^{-} \mathrm{Cl}^{-}$ via canais de $\mathrm{Cl}^{-}$basais (Putzenlechner et al., 1992; Genovese et al., 2005). Já a enzima $\mathrm{Na}^{+} / \mathrm{K}^{+}$-ATPase, localizada na membrana basal dos ionócitos (Towle \& Kays, 1986), ao hidrolisar ATP, exporta três $\mathrm{Na}^{+}$para a hemolinfa em troca de dois $\mathrm{K}^{+}$para o citosol. Esse transporte ativo alimentado pelo influxo de $\mathrm{Na}^{+}$apical mantém as concentrações de $\mathrm{Na}^{+}$e $\mathrm{K}^{+}$ altas no meio extra e intracelular, respectivamente (Kirschner, 2004; Freire et al., 2008a; Faleiros et al., 2010). Junções septadas apicais extensas entre os ionócitos impedem a difusão paracelular de íons da hemolinfa ao meio diluído (Onken et al., 1995; Furriel et al., 2010).

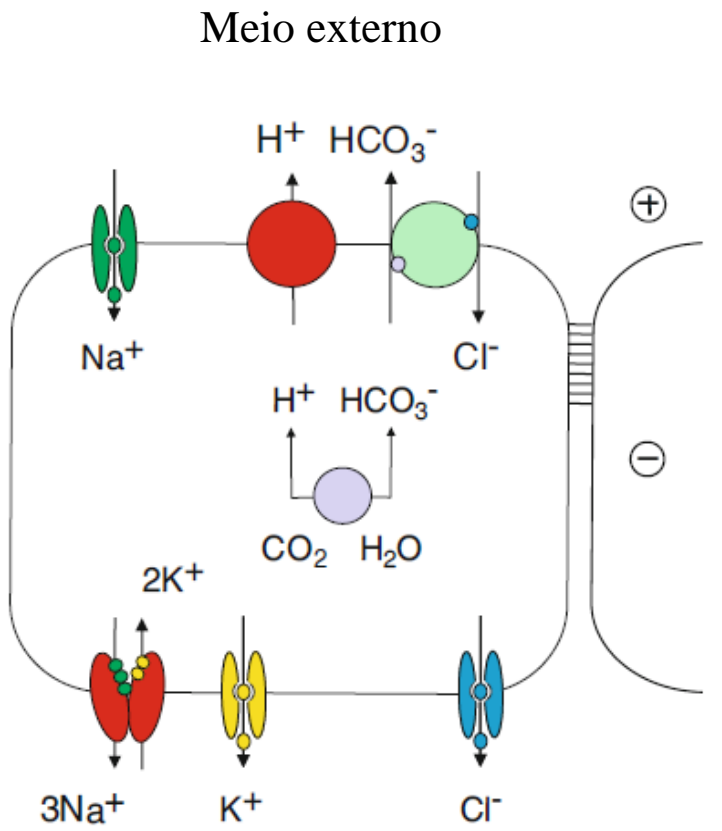

Hemolinfa
Figura 2. Neste modelo para captação de sal em braquiúros hiper-reguladores fortes de água doce, canais de $\mathrm{Na}^{+}$estão associados com a V(H+)ATPase na membrana apical (Onken et al., 1991; Onken \& Putzenlechner, 1995). Essa prótonATPase bombeia $\mathrm{H}^{+}$ativamente para o espaço subcuticular, hiperpolarizando a membrana apical e promovendo a entrada de $\mathrm{Na}^{+}$na célula pelos canais de $\mathrm{Na}^{+}$apicais, de acordo com o gradiente eletroquímico. $\mathrm{O}$ antiportador apical $\mathrm{Cl}^{-} / \mathrm{HCO}_{3}{ }^{-}$ captura $\mathrm{Cl}^{-}$, que sai pela membrana basal por canais de $\mathrm{Cl}^{-}$(Onken et al., 1991; Onken \& Putzenlechner, 1995). O Na ${ }^{+}$é trocado por $\mathrm{K}^{+}$pela $\mathrm{Na}^{+} / \mathrm{K}^{+}$-ATPase na membrana basal, seguindo para a hemolinfa. Junções septadas apicais extensas no epitélio impedem a difusão paracelular de íons (Onken et al., 1995, Furriel et al., 2010). A V( $\mathrm{H}^{+}$)ATPase apical e a $\mathrm{Na}^{+} / \mathrm{K}^{+}$-ATPase basal sustentam a captação de íons contra gradientes elevados $\left(\mathrm{Na}^{+}\right.$ 1: 65, $\mathrm{Cl}^{-}$1: 40) (Onken et al., 1995; Freire et al., 2008a). Apenas um lado da lamela branquial está demonstrado aqui, e a cutícula apical não está representada (McNamara \& Faria, 2012).

As atividades enzimáticas da $\mathrm{Na}^{+} / \mathrm{K}^{+}$-ATPase e $\mathrm{V}\left(\mathrm{H}^{+}\right)$-ATPase se correlacionam com as concentrações intracelulares de íons e com a disponibilidade de substrato (ATP- $\mathrm{Mg}^{2+}$ ), revelando adaptações bioquímicas associadas à vida em meio diluído (Ahearn et al., 1999; Furriel et al., 2010; Firmino et al., 2011; França et al., 2013; Lucena et al., 2015). A maior atividade dessas ATPases resulta em aumento no transporte de prótons $\mathrm{H}^{+}$, no caso da $\mathrm{V}\left(\mathrm{H}^{+}\right)$ATPase, ou de íons $\mathrm{Na}^{+}$e $\mathrm{K}^{+}$, no caso da $\mathrm{Na}^{+} / \mathrm{K}^{+}$-ATPase. Uma vez que os íons se deslocam 
contra o gradiente iônico, há maior gasto de ATP quanto maior a atividade dessas enzimas. Em habitat diluído, essas ATPases trabalham ativamente para capturar os poucos íons disponíveis e que por difusão tendem a ser perdidos do meio intracelular ou da hemolinfa para o meio externo.

Além do poder hiper-osmorregulatório, algumas espécies dulcícolas também exibem elevado poder hipo-osmorregulatório (Freire et al., 2003). No entanto, este último é pouco significante quando comparado à capacidade hipo-regulatória de espécies que enfrentam variação diária e sazonal de salinidade, ou que são semi-terrestres (Freire et al., 2003; Faleiros et al., 2017; Faria et al., 2017) supostamente em decorrência da perda do valor adaptativo da capacidade de secretar sal em habitat dulcícola (McNamara \& Faria, 2012; McNamara et al., 2015).

Em contrapartida, o mecanismo de secreção de sal é direcionado pela $\mathrm{Na}^{+} / \mathrm{K}^{+}$-ATPase e pelo simportador $\mathrm{Na}^{+} / \mathrm{K}^{+} / 2 \mathrm{Cl}^{-}$, localizados nas invaginações basais dos ionócitos (Figura 3). $\mathrm{Na}^{+}, \mathrm{K}^{+}$e $\mathrm{Cl}^{-}$dirigem-se da hemolinfa para o citoplasma por meio do simportador $\mathrm{Na}^{+} / \mathrm{K}^{+} / 2 \mathrm{Cl}^{-}$, impulsionado pelo gradiente de concentração de $\mathrm{Na}^{+}$para dentro do ionócito, que é gerado pela $\mathrm{Na}^{+} / \mathrm{K}^{+}$-ATPase basal e pelo influxo passivo de $\mathrm{Na}^{+}$a partir do meio externo. $\mathrm{Na}^{+}$retorna à hemolinfa pela $\mathrm{Na}^{+} / \mathrm{K}^{+}$-ATPase, enquanto o $\mathrm{K}^{+}$é reciclado por canais de $\mathrm{K}^{+}$basais que sustentam o potencial celular negativo, o qual, por sua vez, impulsiona o efluxo de $\mathrm{Cl}^{-}$por canais de $\mathrm{Cl}^{-}$apicais. $\mathrm{O}$ acúmulo de $\mathrm{Cl}^{-}$no espaço subcuticular gera uma voltagem transepitelial negativa que leva ao efluxo paracelular de $\mathrm{Na}^{+}(\mathrm{McNamara} \&$ Faria, 2012). 


\section{Meio externo}

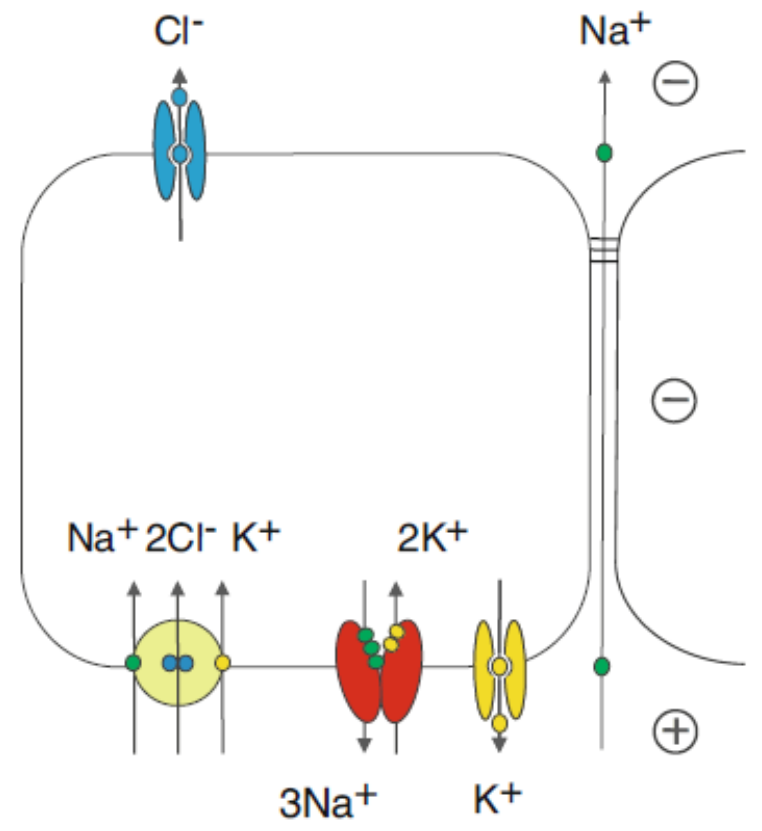

Figura 3. Modelo de secreção de sal em crustáceos hiper/hipo-osmorreguladores e hiporreguladores de $\mathrm{Cl}^{-}$. A secreção predita é direcionada pela $\mathrm{Na}^{+} / \mathrm{K}^{+}$-ATPase basal e pelo simportador $\mathrm{Na}^{+} / \mathrm{K}^{+} / 2 \mathrm{Cl}^{-}$, localizados nas invaginações da membrana basal dos ionócitos (Luquet et al. 2002, 2005). Os íons $\mathrm{Na}^{+}$e $\mathrm{Cl}^{-}$entram no citoplasma a partir da hemolinfa através do $\mathrm{Na}^{+} / \mathrm{K}^{+} / 2 \mathrm{Cl}^{-}$, impulsionado pelo gradiente de $\mathrm{Na}^{+}$para dentro da célula. $\mathrm{O} \mathrm{Na}^{+}$volta à hemolinfa pela $\mathrm{Na}^{+} / \mathrm{K}^{+}$-ATPase, enquanto o $\mathrm{K}^{+}$é reciclado por canais de $\mathrm{K}^{+}$basais, sustentando $\mathrm{o}$ potencial eletronegativo que impulsiona $\mathrm{Cl}^{-}$ para o meio externo por canais de $\mathrm{Cl}^{-}$apicais. $\mathrm{O}$ acúmulo de $\mathrm{Cl}^{-}$no espaço subcuticular gera uma voltagem negativa que ocasiona o efluxo paracelular de $\mathrm{Na}^{+}$(Martinez et al., 1998). Nesse esquema a cutícula não está representada (McNamara \& Faria, 2012).

\section{Hemolinfa}

$\mathrm{O}$ estudo de transporte em células específicas e os aspectos funcionais de transportadores como a $\mathrm{Na}^{+} / \mathrm{K}^{+}$-ATPase, $\mathrm{V}\left(\mathrm{H}^{+}\right)$-ATPase e anidrase carbônica, em resposta aos desafios osmóticos, lideram as pesquisas osmorregulatórias, pois os genes que codificam essas proteínas estão entre os mais expressos durante esses processos (Leone et al., 2005; Moshtaghi et al., 2016; Rahi et al., 2017). Por serem abundantes nas células branquiais (McNamara \& Torres, 1999; Faleiros et al., 2010; Boudour-Boucheker et al., 2014; Maraschi et al., 2015; Faleiros et al., 2017) e por estabelecerem gradientes eletroquímicos através das membranas de modo geral (Péqueux, 1995; Freire et al., 2008a; McNamara \& Faria, 2012; Havird et al., 2013), esses transportadores iônicos apresentam alterações relativas à atividade enzimática, expressões gênica e proteica e localização da proteína, como resposta de ajuste à concentração iônica do meio circundante (Lima et al., 1997; Weihrauch et al., 2004; Santos et al., 2007; Belli et al., 2009; Faleiros et al., 2010; Boudour-Boucheker et al., 2014; França et al., 2013; Havird et al., 2013; Maraschi et al., 2015; Faleiros et al., 2017; Freire et al., 2018).

Por sua vez, estudos da biologia molecular de transportadores e trocadores iônicos nas brânquias e demais tecidos osmorregulatórios dos decápodes entraram em cena apenas nas duas últimas décadas (Towle et al., 1997; Weihrauch et al., 2001, 2004; Wheatly \& Gao, 2004; Leone et al., 2005; Faleiros et al., 2010). Ocasionalmente, tais estudos incorporam uma 
perspectiva filogenética (Sáez et al., 2009; Havird et al., 2013), que podem ser baseadas em diferenças de sequências parciais de cDNA relativas a transportadores envolvidos na osmorregulação (McNamara \& Faria, 2012).

Em nosso Laboratório de Fisiologia de Crustáceos temos investigado as bases moleculares da captação e secreção de sal em crustáceos decápodes, sobretudo avaliando a expressão de genes codificadores de transportadores iônicos em diversos crustáceos de diferentes ordens e habitats, quando aclimatados a meios diluídos ou concentrados (Weihrauch et al., 2004; Leone et al., 2005; Faleiros et al., 2010; Lucena et al., 2015). Entendemos que a biologia molecular tornou-se ferramenta imprescindível para a compreensão da regulação osmótica, em vários níveis de organização estrutural (Masui et al., 2008; Faleiros et al., 2010), além de elucidar a natureza de eventos reguladores e seu papel na história evolutiva dos grupos extantes (McNamara \& Faria, 2012).

Assim sendo, no presente trabalho de doutoramento, examinamos os mecanismos osmorregulatórios e realizamos estudos moleculares usando como modelos o caranguejo Dilocarcinus pagei (Stimpson, 1861) e ao camarão Macrobrachium jelskii (Miers, 1877). Ambos são hiper-osmorreguladores fortes, termo que se refere a espécies que habitam ou migram para a água doce, onde passam a maior parte do ciclo de vida (Freire et al., 2008a).

\subsection{O caranguejo vermelho de água doce, Dilocarcinus pagei}

Ao longo do processo evolutivo, muitos decápodes irradiaram a partir de um ambiente marinho para meios mais diluídos (Schubart et al., 1998), sendo que espécies ancestrais de Dilocarcinus pagei (Figura 4) colonizaram habitats de água doce, tornando-se completamente independentes da água do mar, inclusive para desenvolvimento e reprodução (Augusto et al., 2007b).

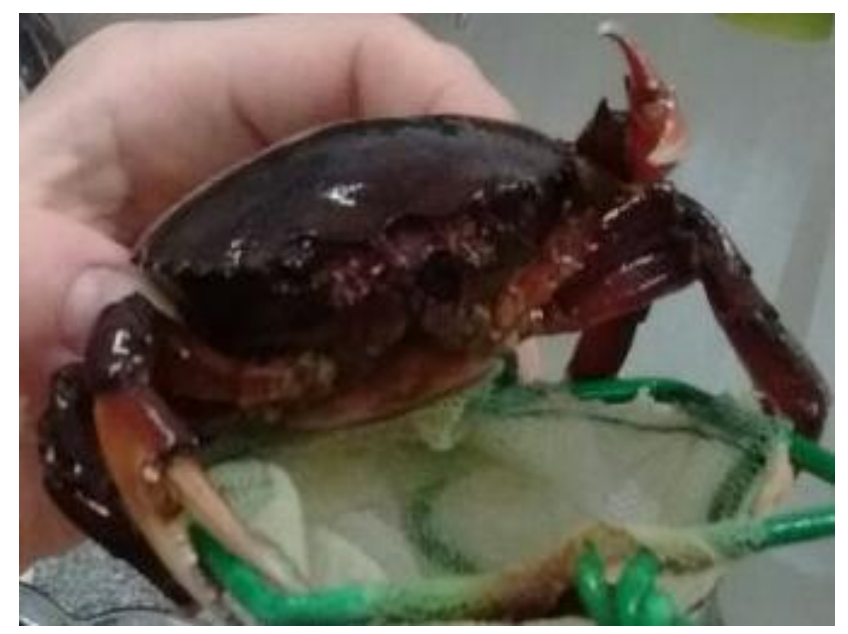

Figura 4. Espécime do caranguejo Dilocarcinus pagei. 
Dilocarcinus pagei é um caranguejo braquiúro da América do Sul, endêmico à bacia Amazônica e as dos rios Paraguai e Paraná, pertencente à família Trichodactylidae (Milne Edwards, 1853). É um habitante de água doce antigo e bem adaptado, com forte poder de hiperregulação anisosmótica e anisoiônica (Onken \& McNamara, 2002), com baixos pontos isosmótico e isoiônico, embora não produza urina diluída (Augusto et al., 2007b). É experimentalmente eurialino, pois, surpreendentemente, sobrevive em meio de salinidade elevada (35\%oS) (Augusto et al., 2007b). Possui filobrânquias, com as lamelas das brânquias posteriores estrutural e funcionalmente diferenciadas das anteriores (Onken \& McNamara, 2002). Análises morfológicas, eletrofisiológicas e de expressão gênica semi-quantitativa de transportadores confirmam que as três brânquias posteriores são o sítio principal de captação iônica (Onken \& McNamara, 2002; Weihrauch et al., 2004).

Neste caranguejo, os epitélios opostos das lamelas das brânquias posteriores são assimétricos, separados por um espaço irregular preenchido por hemolinfa e pericários de células pilares. As células pilares, um tipo de ionócito, apresentam duas regiões distintas: o pericário e a franja apical, uma delicada expansão do pericário. O epitélio fino (distal) é constituído por franjas apicais bem desenvolvidas acima dos pericários das células pilares. $\mathrm{O}$ epitélio espesso (proximal) é composto por outro tipo de célula, ionócitos cubóides, que possui extensas invaginações basais e poucas vesículas (Weihrauch et al., 2004).

As brânquias anteriores estão envolvidas nas trocas gasosas e apresentam epitélios simétricos, sobrepostos por cutícula em ambos os lados das lamelas. São formados pelas franjas de células pilares, consistindo de um epitélio muito fino e vesiculado, separados por um amplo espaço preenchido por hemolinfa e discontinuado por septos (Weihrauch et al., 2004).

Dilocarcinus pagei possui captura ativa e independente de $\mathrm{Na}^{+} \mathrm{e}^{-}$, sendo o epitélio das brânquias posteriores responsável por manter elevados gradientes osmótico e iônico contra o meio externo $(\approx 30: 1)$. Em uma mesma lamela branquial, o transporte ativo de $\mathrm{Na}^{+}$ se dá através do espesso epitélio proximal tendo a $\mathrm{Na}^{+} / \mathrm{K}^{+}$-ATPase como força motriz, enquanto o transporte de $\mathrm{Cl}^{-}$ocorre pelo fino epitélio distal, direcionado pela atividade da $\mathrm{V}\left(\mathrm{H}^{+}\right)$-ATPase (Onken \& McNamara, 2002; Weihrauch et al., 2004; Feire et al., 2008a; Firmino et al., 2011) (Figura 5). A osmolalidade da hemolinfa nessa espécie, quando em água doce, é de aproximadamente $386 \mathrm{mOsm} \mathrm{kg}^{-1} \mathrm{H}_{2} \mathrm{O}$, enquanto as concentrações de $\mathrm{Na}^{+} \mathrm{e} \mathrm{Cl}^{-}$são de aproximadamente 190 e 206 mM, respectivamente (Onken \& McNamara, 2002). 


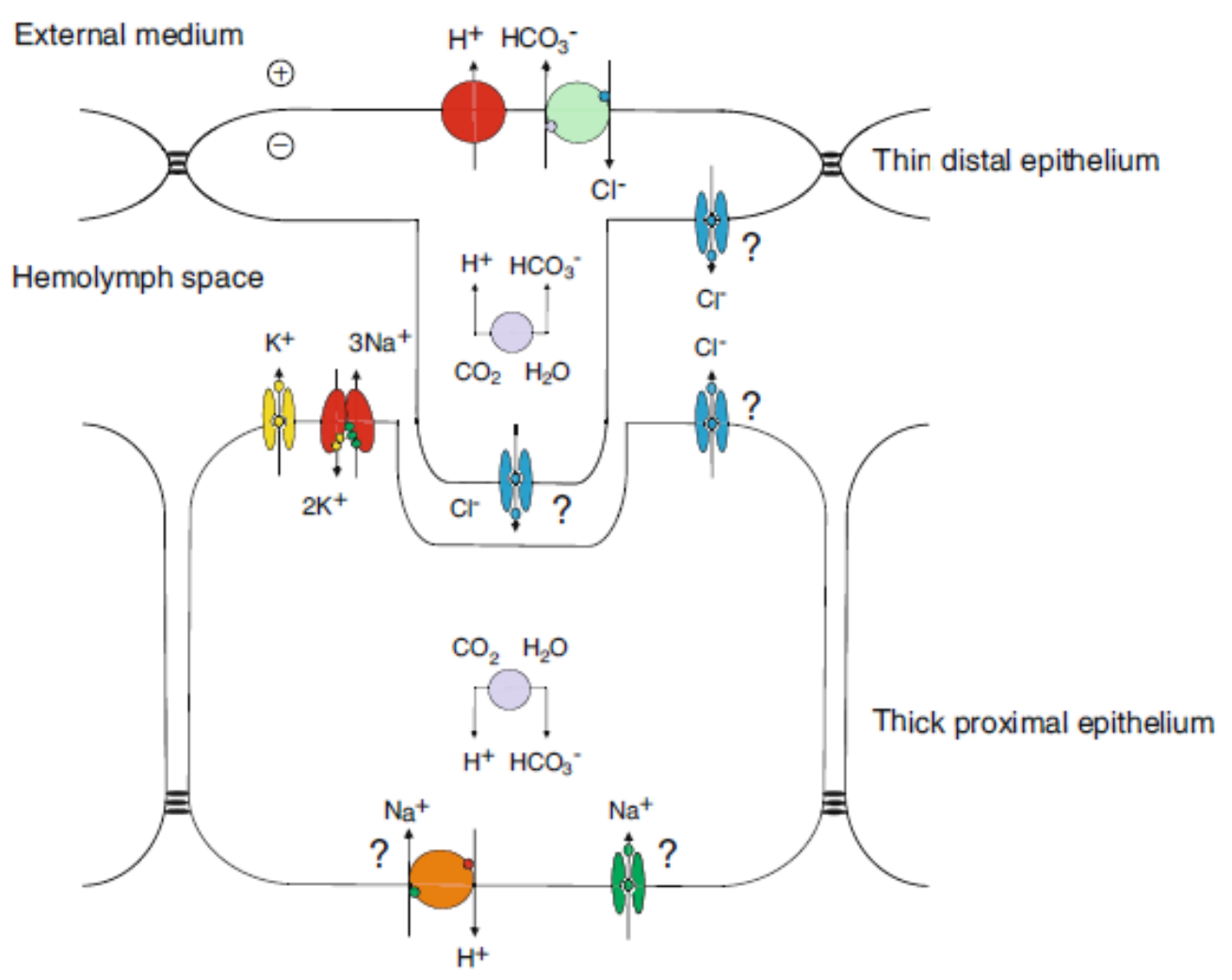

Figura 5. Arranjo das proteínas ionotransportadoras em ionócitos de Dilocarcinus pagei. As bombas e os transportadores iônicos, tipicamente encontrados em fortes hiperreguladores, são separados espacialmente nos ionócitos do espesso epitélio proximal e nos ionócitos do fino epitélio distal, os quais transportam de forma independente $\mathrm{Na}^{+}$e $\mathrm{Cl}^{-}$, respectivamente (Onken \& McNamara 2002). O epitélio fino é constituído por células pilares que transportam $\mathrm{Cl}^{-}$, o que é baseado no transporte de $\mathrm{H}^{+}$para o meio externo pela $\mathrm{V}\left(\mathrm{H}^{+}\right)$-ATPase (Weihrauch et al., 2004; Firmino et al. 2011) e pelo antiportador $\mathrm{Cl}^{-} / \mathrm{HCO}_{3}{ }^{-}$apicais. O epitélio espesso capta $\mathrm{Na}^{+}$ por meio da $\mathrm{Na}^{+} / \mathrm{K}^{+}$-ATPase basal (Onken \& McNamara 2002; Furriel et al., 2010), transporte possivelmente sustentado pelo antiportador apical $\mathrm{Na}^{+} / \mathrm{H}^{+}$ou canais de $\mathrm{Na}^{+}$. A anidrase carbônica citosólica hidrata o $\mathrm{CO}_{2} \mathrm{e}$ fornece $\mathrm{H}^{+}$e $\mathrm{HCO}_{3}{ }^{-}$em ambos os epitélios. A cutícula externa não está representada nesse esquema.

\subsection{O camarão sossego de água doce, Macrobrachium jelskii}

O camarão carídeo Macrobrachium jelskii (Figura 6) é endêmico da América do Sul, sendo encontrado em grandes bacias hidrográficas brasileiras (Magalhães et al., 2005; Boos et al., 2012; Pileggi et al., 2013). O gênero Macrobrachium (Spence Bate, 1868) pertence à família Palaemonidae (Rafinesque, 1815) e possui muitas espécies de camarões de água doce distribuídas em regiões tropicais e subtropicais (Holthuis, 1980). Dentre as espécies, 19 são encontradas no Brasil, sendo que Macrobrachium jelskii é exclusivamente encontrada em ambientes de água doce (Vera-Silva et al., 2016). Não necessita de água salobra para o desenvolvimento de seu ciclo de vida (Magalhães, 2000), o que os caracteriza como uma espécie hololimnética. Essa espécie constitui um componente importante da cadeia trófica (Vera-Silva et al., 2016), além de ser economicamente explorada como ornamento em aquários, isca em pesca artesanal e fonte de proteínas para humanos e outros animais (Soares, 
2008; Ottoni et al., 2011; Barros-Alves et al., 2012). No entanto, suas características biológicas e estrutura genética não são muito conhecidas.

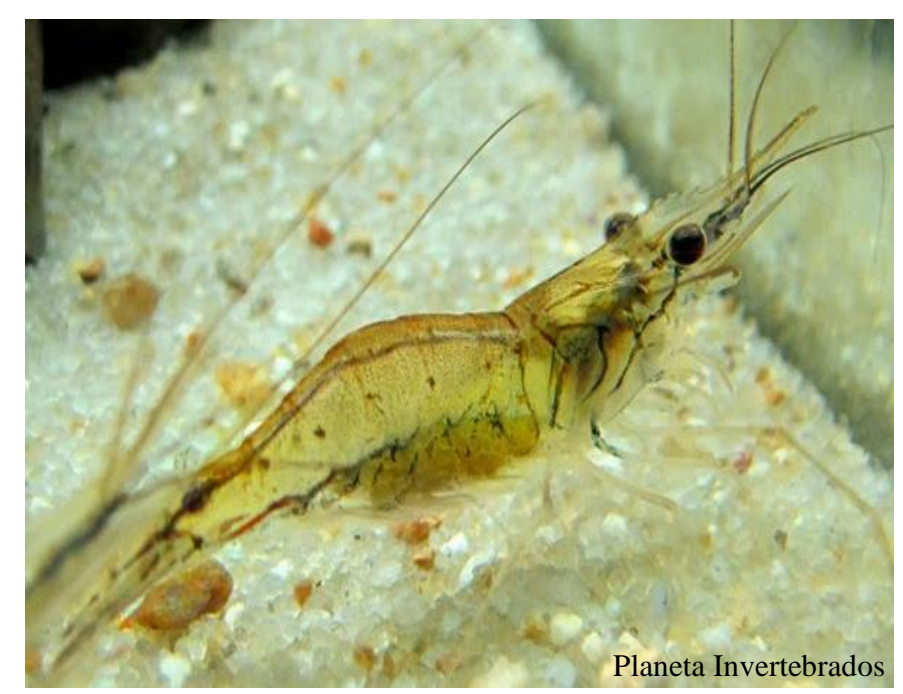

Figura 6. Espécime do camarão Macrobrachium jelskii.

A reconstrução de estados ancestrais por análises de parcimônia revela que os palemonídeos se originaram em água salobra (17\% S, McNamara \& Faria, 2012), com posterior invasão de meios diluídos por Macrobrachium e Palaemonetes, sustentado por mecanismos osmorregulatórios que permitiram um aumento no gradiente mantido entre a hemolinfa e o ambiente de baixa osmolalidade (McNamara et al., 2015), além da redução da permeabilidade do epitélio branquial (Freire et al., 2008a; McNamara \& Faria, 2012; McNamara et al., 2015). Isso provavelmente resultou em capacidade regulatória extracelular hiper-anisosmótica, como é agora observado em espécies de nichos osmoticamente variáveis (Augusto et al., 2009; Freire et al., 2003; 2008a). Espécies diádromas (que alternam entre a água doce e a salgada, dependendo do estágio do ciclo de vida) e hololiméticas do gênero Macrobrachium são fortes hiper-reguladoras (Moreira et al., 1983; Freire et al., 2003; Faria et al., 2011), com osmolalidade da hemolinfa de aproximadamente $400 \mathrm{mOsm} \mathrm{kg}^{-1} \mathrm{H}_{2} \mathrm{O}$ (Moreira et al., 1983; Freire et al., 2003; Faleiros et al., 2010; Maraschi et al., 2015). Espécies do gênero Macrobrachium, todavia, perderam significativamente a capacidade hipoosmorregulatória, possivelmente devido ao baixo valor adaptativo da capacidade de secreção de sal em ambientes de água doce (McNamara et al., 2015), embora estudos sobre a evolução do mecanismo intraespecífico de secreção de sal entre os palemonídeos sejam escassos (McNamara \& Faria, 2012).

Ao contrário das brânquias de caranguejos (Taylor \& Taylor, 1992; Péqueux, 1995; Henry et al., 2012), as filobrânquias dos camarões palemonídeos não se diferenciam estrutural 
e funcionalmente (Freire et al., 2008a) e participam igualmente na captação e secreção iônica, excreção de amônia, trocas gasosas e regulação de pH (McNamara et al., 2015). As lamelas branquiais são constituídas por pelo menos dois tipos celulares: as células pilares e as células do septo. A membrana apical das células pilares é sobreposta por uma fina cutícula e possui um extenso sistema de evaginações, principalmente acima do pericário. O citoplasma subapical contém pequenas e numerosas vesículas, ribossomos, mitocôndrias, retículo endoplasmático e microtúbulos inseridos na base das evaginações (Freire \& McNamara, 1995). Já as franjas apicais são cada vez mais finas conforme se distanciam do pericário, e o número de evaginações e organelas também diminui, indicando a ausência de transporte ativo e movimentação de sal nessa região (McNamara \& Lima, 1997). A região de contato entre as franjas de células pilares adjacentes é constituída por extensos complexos juncionais (McNamara \& Lima, 1997; Belli et al., 2009; McNamara et al., 2015). A distribuição diferencial das evaginações sugere que a membrana apical do pericário é o principal sítio de troca iônica. Já as trocas gasosas ocorrem preferencialmente nas extremidades das franjas, as quais formam uma barreira fina de citoplasma, diretamente em contato com a hemolinfa (McNamara \& Lima, 1997; Belli et al., 2009; McNamara et al., 2015).

Com relação às células intralamelares do septo, há inúmeras invaginações da superfície celular, as quais penetram profundamente o citoplasma e são ricas em mitocôndrias. Tipicamente, uma célula septal conecta a base de duas células pilares adjacentes e a maior parte de sua superfície está em contato com a hemolinfa (McNamara \& Lima, 1997; Belli et al., 2009; McNamara et al., 2015). A maquinaria subcelular que sustenta a captação ativa de $\mathrm{Na}^{+}$reside nas invaginações das células do septo, rico em mitocôndrias (McNamara \& Lima, 1997; McNamara \& Torres, 1999; Belli et al., 2009) (Figura 7). A membrana apical das células pilares aloca a $\mathrm{V}\left(\mathrm{H}^{+}\right)$-ATPase (Faleiros et al., 2010), canais de $\mathrm{Na}^{+}$e o antiportador $\mathrm{Cl}^{-} / \mathrm{HCO}_{3}{ }^{-}$(McNamara \& Faria, 2012), os quais estão fisicamente separados da $\mathrm{Na}^{+} / \mathrm{K}^{+}-$ ATPase das células septais (McNamara \& Torres, 1999). 


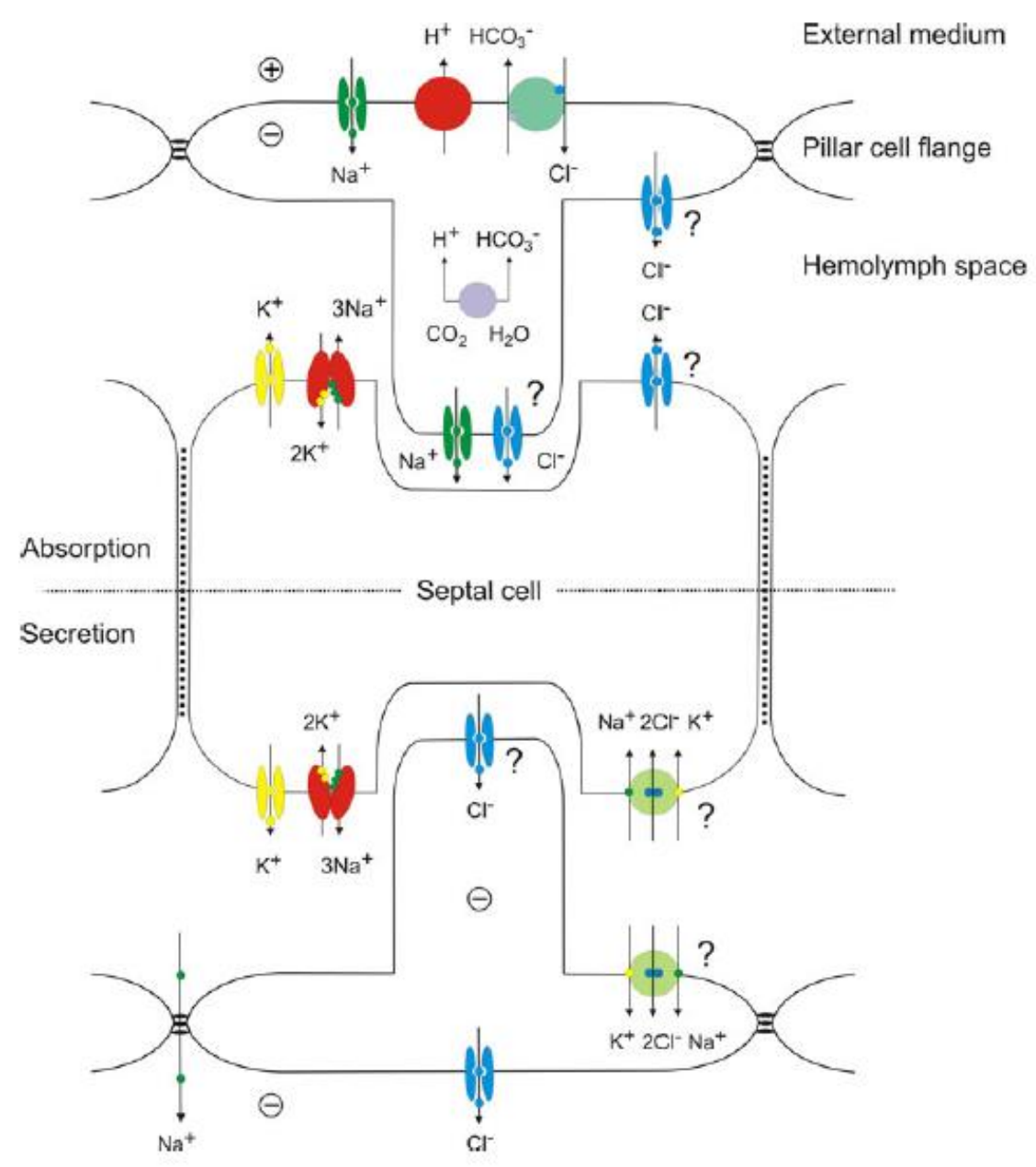

Figura 7. Modelo hipotético para a captura ou secreção de sal em camarões palemonídeos de água doce. Os transportadores estão distribuídos em dois tipos de ionócitos que compõem o epitélio branquial. A $\mathrm{Na}^{+} / \mathrm{K}^{+}-$ ATPase age como força motriz na captação de sal (parte superior da figura) e está localizada nas invaginações ricas em mitocôndrias, presentes nas células do septo (McNamara \& Torres, 1999). Outra força motriz na captação de sal é a $\mathrm{V}\left(\mathrm{H}^{+}\right)$-ATPase, localizada na membrana apical da região da franja das células pilares (Furriel et al., 2010; Faleiros et al., 2010). Canais de $\mathrm{Na}^{+}$presentes na região apical das franjas permitem a entrada desse íon no citoplasma, que se difunde para as células do septo onde é transportado ativamente pela $\mathrm{Na}^{+} / \mathrm{K}^{+}-\mathrm{ATPase}$ para a hemolinfa. $\mathrm{O}$ antiportador apical $\mathrm{Cl}^{-} / \mathrm{HCO}_{3}{ }^{-}$permite a entrada de $\mathrm{Cl}^{-}$, que chega à hemolinfa via canais de $\mathrm{Cl}^{-}$na membrana inferior das franjas das células pilares (Torres, 2006), ou via canais basais de $\mathrm{Cl}^{-}$presentes nas células do septo. $\mathrm{Na}$ secreção de sal (parte inferior da figura), $\mathrm{o} \mathrm{Cl}^{-}$entra nas células do septo ou na hemolinfa pelo simportador $\mathrm{Na}^{+} / \mathrm{K}^{+} / 2 \mathrm{Cl}^{-}$(Luquet et al., 2002; 2005), direcionado pelo gradiente de $\mathrm{Na}^{+}$. $\mathrm{O} \mathrm{Cl}^{-}$sai por canais de $\mathrm{Cl}^{-}$na membrana apical das franjas, criando um potencial elétrico negativo no espaço subcuticular, que direciona o efluxo de $\mathrm{Na}^{+}$pela via paracelular (Russell 2000; Pullikuth et al., 2003; Yang et al., 2011). As cutículas que recobrem o epitélio não estão representadas (McNamara \& Faria, 2012).

Os processos de RII e RAE, atuantes na homeostase osmótica e iônica, são efetuados pelos ionócitos (representados nas Figuras 5 e 7), e decorrem do arranjo celular e distribuição de proteínas ionotransportadoras, simportadores e canais iônicos. Sobretudo, nos modelos representados, atua principalmente a RAE, mecanismo predominante em osmorreguladores, como D. pagei e M. jelskii. 
Dessa forma, visando caracterizar os mecanismos da RAE que possibilitam a absorção e secreção de sal pelas brânquias de crustáceos de água doce, nós investigamos aspectos fisiológicos e moleculares em brânquias do caranguejo D. pagei e do camarão M. jelskii, frente a desafios osmóticos e iônicos, proporcionados pela exposição a concentrações de sal menores $(0 \% \mathrm{~S})$ ou maiores $(25 \% \mathrm{~S}$ para D. pagei e $20 \% \mathrm{~S}$ para $M$. jelskii) daquelas de seus habitats naturais. Ao comparamos os parâmetros osmorregulatórios (osmolalidade e concentração de $\mathrm{Cl}^{-}$e $\mathrm{Na}^{+}$), percebemos que, embora Dilocarcinus pagei e Macrobrachium jelskii sejam filogeneticamente distantes, estes valores se assemelham na água doce. Dessa forma, questionamos se seus mecanismos osmorregulatórios dependem dos mesmos transportadores, se estes respondem de forma semelhante a desafios osmóticos, e se são oriundos de convergência adaptativa.

A nossa hipótese é de que as respostas de ambas as espécies, frente aos desafios osmóticos, serão diferentes, pois D. pagei e M. jelskii evoluíram por caminhos distintos, embora ambos resultaram na ocupação da água doce. Dilocarcinus pagei pertence à família Trichodactylidae (Milne Edwards, 1853), cujas espécies teriam surgido há ₹130 milhões de anos (Collins et al., 2011). As espécies do gênero Macrobrachium teriam surgido há $\approx 30$ milhões de anos (Short 2004; Murphy \& Austin 2005; De Grave et al., 2009; Ashelby et al., 2012), sendo que $M$. jelskii tem $\approx 22$ milhões de anos (Jose \& Harikrishnan, 2019). 
Objetivos 


\section{Objetivos}

\section{$\underline{2.1 \text { Objetivo geral }}$}

Investigar as bases moleculares subjacentes a mecanismos osmorregulatórios em crustáceos de água doce da ordem Decapoda, especificamente nas espécies Dilocarcinus pagei (Brachyura, Trichodactylidae) e Macrobrachium jelskii (Caridea, Palaemonidae), visando fornecer subsídios para análises filogenéticas/fenéticas/filo-fisiológicas.

\section{$\underline{\text { 2.2 Objetivos específicos }}$}

2.2.1 Determinar o limite letal superior de salinidade em que há 50\% de morte dos animais experimentados ( $\left.\mathrm{LSS}_{50}\right)$ após 120 horas e estimar a salinidade experimental (80\% do valor da $\mathrm{LSS}_{50}$ ) para desafio osmótico experimental na espécie Macrobrachium jelskii;

2.2.2 Obter as sequências de bases parciais dos cDNAs (região codificadora) que expressam a subunidade $\alpha$ da $\mathrm{Na}^{+} / \mathrm{K}^{+}$-ATPase e a subunidade $\mathrm{B}$ da $\mathrm{V}\left(\mathrm{H}^{+}\right)$-ATPase, em brânquias de Macrobrachium jelskii, bem como a sequência de bases do simportador $\mathrm{Na}^{+} / \mathrm{K}^{+} / 2 \mathrm{Cl}^{-}$e da proteína ribossomal L10 (PRL10), a partir de brânquias de Macrobrachium jelskii e Dilocarcinus pagei;

2.2.3 Analisar a regulação osmótica e as concentrações de cloreto e sódio na hemolinfa de Dilocarcinus pagei e Macrobrachium jelskii, quando expostos à água destilada $(0,0 \% \mathrm{O})$, água do local de coleta $(<0,5 \% \mathrm{~S})$ ou água salobra de salinidade subletal para a espécie $(25$ $\%_{0}$ S para $D$. pagei e $20 \%$ S para $M$. jelskii), durante um decurso temporal de 1 hora a 10 dias de exposição;

2.2.4 Avaliar a expressão gênica quantitativa dos transportadores iônicos $\mathrm{Na}^{+} / \mathrm{K}^{+}$ATPase, $\mathrm{V}\left(\mathrm{H}^{+}\right)$-ATPase e $\mathrm{Na}^{+} / \mathrm{K}^{+} / 2 \mathrm{Cl}^{-}$nas brânquias de Dilocarcinus pagei e Macrobrachium jelskii, quando expostos a desafio hipo-osmótico (água destilada, 0,0\% \% S), água do local de coleta (condição controle, <0,5\%oS) e água salobra (desafio hiperosmótico, $25 \% \mathrm{~S}$ para $D$. pagei e $20 \% \mathrm{~S}$ para $M$. jelskii), durante um decurso temporal de 1 hora a 10 dias de exposição; 
2.2.5 Correlacionar as expressões gênica e proteica dos transportadores iônicos $\mathrm{Na}^{+} / \mathrm{K}^{+}$ATPase e $\mathrm{Na}^{+} / \mathrm{K}^{+} / 2 \mathrm{Cl}^{-}$das brânquias de Dilocarcinus pagei e Macrobrachium jelskii;

2.2.6 Construir fenogramas para representação visual da identidade das sequências de bases que codificam as proteínas ionotransportadoras $\mathrm{Na}^{+} / \mathrm{K}^{+}$-ATPase, $\mathrm{V}\left(\mathrm{H}^{+}\right)$-ATPase, $\mathrm{Na}^{+} / \mathrm{K}^{+} / 2 \mathrm{Cl}^{-}$e a proteína ribossomal L10, utilizando sequências semelhantes $(\geq 69 \%)$ de espécies representativas de famílias pertinentes dos decápodes, em relação às de Dilocarcinus pagei e Macrobrachium jelskii. 
Material e Métodos 


\section{Material e Métodos}

\subsection{Metodologia específica para o caranguejo Dilocarcinus pagei}

\subsubsection{Coleta, manutenç̃o e aclimatacão dos animais em diferentes salinidades}

Exemplares do braquiúro Dilocarcinus pagei de ambos os sexos e com tamanho variando entre 3,0 e 6,0 cm (medida longitudinal da carapaça) foram coletados em dois reservatórios de água doce do município de Sertãozinho (48 $48^{\circ}$ ' 06,54” O, $21^{\circ} 06^{\prime} 35,21^{\prime \prime} \mathrm{S}$ e $48^{\circ} 03^{\prime} 12,57^{\prime \prime} \mathrm{O}, 21^{\circ} 08^{\prime} 26,35^{\prime}$ S), localizado a nordeste do estado de São Paulo.

Os caranguejos foram coletados com peneiras e/ou pequenas armadilhas de plástico iscadas, sob os números de autorização 29594-8 e 29594-9, do Instituo Chico Mendes de Conservação da Biodiversidade (ICMBio), do Ministério do Meio Ambiente.

Foram transportados ao Laboratório de Fisiologia de Crustáceos da Faculdade de Filosofia, Ciências e Letras de Ribeirão Preto/USP em potes plásticos contendo água do local de coleta e, para a aclimatização inicial, foram mantidos em tanques plásticos arejados e inclinados, contendo aproximadamente $5 \mathrm{~L}$ de água do local de coleta, de modo a formar uma área seca e outra com água, já que esses caranguejos vivem em habitat semi-terrestres. Todos os tanques foram providos de tijolos ocos para refúgio dos animais, sendo as condições de manutenção verificadas diariamente, principalmente aeração, limpeza, eventos de ecdise e morte dos caranguejos. A cada dois dias foram oferecidos carne bovina, camarão ou cenoura, e o resto dos alimentos foi retirado da água após algumas horas da exposição.

A aclimatização às condições laboratoriais foi realizada durante 3 a 4 dias antes do inicio dos experimentos. Em seguida, cada caranguejo foi transferido para um recipiente plástico de $4 \mathrm{~L}$ de capacidade, contendo $2 \mathrm{~L}$ de um dos 2 meios com salinidade experimentais: água destilada ( $0 \mathrm{~g} \mathrm{sal} / \mathrm{L}[\% \mathrm{~S}])$, representando um desafio hiposmótico severo, e água do mar diluída a $25 \mathrm{~g} / \mathrm{L}$ [\%oS], consistindo em um desafio hiperosmótico para a espécie, por um dos intervalos de tempo estipulados: 1, 3, 5, 12, 24 horas e 3 ou 10 dias. Visando impossibilitar a recaptação de íons excretados ou perdidos por difusão, a água destilada foi trocada nos intervalos de 1, 2, 4, 7 e 12 horas e, subsequentemente, de 12 em 12 horas. Já a água do mar oriunda do Canal de São Sebastião, estado de São Paulo, foi diluída a 25 g/L [\%oS] com água do local de coleta e trocada a cada 24 horas de experimentação. A salinidade de $25 \mathrm{~g} / \mathrm{L}$ [\%oS] representa um desafio hiperosmótico severo para a espécie, sendo aproximadamente $87 \%$ da salinidade letal superior em que há $50 \%$ de morte $\left(\operatorname{LSS}_{50}\right)$, de acordo com a análise Probit, a qual acomoda o percentual de sobrevivência em um modelo de regressão linear (Finney, 
1971; Thurman, 2002, 2003). Essa análise foi realizada com dados de sobrevivência relatados para D. pagei por Augusto et al. (2007b), após 8 dias de exposição dos caranguejos em água com salinidades de 20 a $35 \%$ S, e a concentração de $25 \%$ S foi a mesma utilizada em vários experimentos dos autores.

O grupo controle foi formado por caranguejos mantidos nas condições de aclimatização laboratorial por 7 dias, sendo esse tempo constituído por aclimatização inicial de 4 dias, acrescido de uma "experimentação" de 3 dias, e definido como tempo = 0 hora.

\subsubsection{Medidas de osmolalidade e das concentracões de $\mathrm{Cl}^{-}$e $\mathrm{Na}^{+}$}

Transcorrido cada tempo de exposição de acordo com o decurso temporal estabelecido, os caranguejos foram anestesiados em gelo picado para coleta de 100 a $500 \mu \mathrm{L}$ de hemolinfa da base de um ou mais periópodos, por meio de uma agulha $(25 \times 8)$ acoplada à seringa descartável. As amostras de hemolinfa foram armazenadas em tubos plásticos do tipo eppendorf com $600 \mu \mathrm{L}$ de capacidade e mantidas a $-20{ }^{\circ} \mathrm{C}$ para análises posteriores.

A osmolalidade (mOsm $\mathrm{kg}^{-1} \mathrm{H}_{2} \mathrm{O}$ ) de cada amostra de hemolinfa foi medida em alíquotas de $10 \mu \mathrm{L}$, utilizando-se um osmômetro de pressão de vapor (Wescor, modelo 5500).

A concentração de $\mathrm{Cl}^{-}\left(\mathrm{mmol} \mathrm{L}^{-1}\right)$ foi medida em alíquotas de $10 \mu \mathrm{L}$ de hemolinfa, por microtitulação (Schales \& Schales, 1941, adaptado por Santos \& McNamara, 1996), em microtitulador (Metron Herisou, modelo E 485).

A concentração de $\mathrm{Na}^{+}\left(\mathrm{mmol} \mathrm{L}^{-1}\right)$ da hemolinfa foi medida por absorção atômica (GBC, modelo 932AA) em $5 \mu \mathrm{L}$ de hemolinfa diluída em $100 \mathrm{~mL}$ de água destilada (1: 20.000).

\subsubsection{Disseccão das brânquias}

Após a obtenção da hemolinfa, os caranguejos foram mortos por transecção e destruição dos gânglios cerebral e torácico. A carapaça foi removida e as brânquias expostas, sendo dissecadas com microtesoura e pinça de relojoeiro, em condições livres de RNAse. A sétima brânquia, que é a penúltima brânquia posterior, foi colocada em Trizol (Invitrogen) na proporção de 1: 10 massa/volume e guardadas a $-80{ }^{\circ} \mathrm{C}$ até o uso em metodologias moleculares. 


\section{$\underline{\text { 3.2 Metodologia específica para o camarão Macrobrachium jelskii }}$}

\subsubsection{Coleta, manutenção e aclimatação dos animais em diferentes salinidades}

Exemplares do carídeo Macrobrachium jelskii de ambos os sexos e com tamanho variando entre 3,2 e 5,3 cm (do espinho frontal até a cauda) foram coletados na via fluvial do Clube Náutico de Araraquara (48 01'33” O, 21 ${ }^{\circ} 42^{\prime}$ 17” S), localizado no distrito de Américo Brasiliense, na bacia do Rio Mogi-Guaçu, região central do estado de São Paulo.

Os camarões da vegetação marginal foram coletados com peneiras, sob os números de autorização 29594-8, 29594-9 e 29594-10 do Instituo Chico Mendes de Conservação da Biodiversidade (ICMBio) do Ministério do Meio Ambiente.

Foram transportados ao Laboratório de Fisiologia de Crustáceos da Faculdade de Filosofia, Ciências e Letras de Ribeirão Preto/USP, em potes plásticos contendo água do local de coleta, e mantidos em tanques plásticos arejados. Para aclimatizar os $M$. jelskii, os tanques foram completos com $25 \mathrm{~L}$ de água do local de coleta ou da mina localizada na USP de Ribeirão Preto, uma vez que esses camarões são estritamente aquáticos. Todos os tanques foram providos de tijolos ocos para refúgio dos animais, sendo as condições de manutenção verificadas diariamente, principalmente aeração, limpeza, eventos de ecdise e morte dos camarões. A cada dois dias foram oferecidos carne bovina e/ou cenoura, e o resto dos alimentos foi retirado da água após algumas horas da exposição.

A aclimatização inicial às condições laboratoriais foi realizada durante 3 a 4 dias antes do inicio dos experimentos. Em seguida, grupos de 6 camarões foram transferidos para um recipiente plástico de $4 \mathrm{~L}$ de capacidade, contendo $3 \mathrm{~L}$ (0,5 L por animal) de um dos 2 meios com salinidades experimentais: água destilada ( $0 \mathrm{~g}$ sal/L $[\% \mathrm{~S}])$, que representa um desafio hiposmótico, e água do mar diluída a 20 g/L [\%oS] como desafio hiperosmótico severo e subletal, já que essa concentração representa $80 \%$ da LSS $_{50}$ para a espécie, conforme observado em experimentos com curvas de sobrevivência em águas de diferentes salinidades. Os camarões foram mantidos em um dos 2 meios experimentais por um dos intervalos de tempo estipulados: 1, 3, 5, 12, 24 horas e 3 ou 10 dias. Visando impossibilitar a recaptação de íons excretados ou perdidos por difusão, a água destilada foi trocada nos intervalos de 1, 2, 4, 7 e 12 horas e, subsequentemente, de 12 em 12 horas. A água do mar oriunda do Canal de São Sebastião, estado de São Paulo, foi diluída a 20 g/L [\%oS] com água do local de coleta e foi trocada a cada 24 horas de experimentação. 
O grupo controle foi formado por camarões mantidos nas condições de aclimatização laboratorial por 7 dias, sendo esse tempo constituído por aclimatização inicial de 4 dias, acrescido de uma "experimentação" de 3 dias, e definido como tempo = 0 hora.

\subsubsection{Mortalidade e determinação do limite letal superior de salinidade (LSS 50 )}

\section{para Macrobrachium jelskii}

Para experimentos com curvas de sobrevivências e determinação do limite letal superior de salinidade ( $\mathrm{LSS}_{50}$ ) para Macrobrachium jelskii, os camarões foram divididos em grupos de 5 a 7 indivíduos. Esses grupos foram mantidos em aquários contendo $3 \mathrm{~L}$ de água em uma das concentrações de salinidade: 20, 24, 26 ou 28 g/L [\%oS], com 2 aquários por salinidade experimental $(\mathrm{n}=12)$, durante cinco dias $(120 \mathrm{~h})$. Todos os aquários foram mantidos à temperatura ambiente de aproximadamente $25^{\circ} \mathrm{C}$, com aeração constante.

Averiguou-se a sobrevivência dos camarões a cada 12 horas, sendo considerados mortos aqueles que permaneceram em decúbito lateral após serem colocados na posição natural. $\mathrm{O}$ $\mathrm{LSS}_{50}$ usado aqui corresponde à salinidade em que ocorreram 50\% de mortalidade após $120 \mathrm{~h}$ de exposição. A determinação da LSS $_{50}$ deu-se por meio da análise Probit, que acomoda o percentual de sobrevivência em um modelo de regressão linear (Finney, 1971, Thurman, 2002, 2003). O valor da $\mathrm{LSS}_{50}$ para Macrobrachium jelskii após 120 h foi de 25,4 \%o. A partir deste valor ficou estabelecida a salinidade experimental hiperosmótica de $20 \%$ para a espécie, que corresponde a $80 \%$ da $\mathrm{LSS}_{50}$.

\subsubsection{Medidas de osmolalidade e das concentracões de $\mathrm{Cl}^{-}$e $\mathrm{Na}^{+}$}

Transcorrido cada tempo de exposição, os camarões foram anestesiados em gelo picado para a coleta de hemolinfa pela membrana artrodial, entre o cefalotórax e o abdômen (região pericardial), por meio de pipetagem com ponteiras de $0,1-10 \mu \mathrm{L}$ de capacidade. Como a quantidade de hemolinfa retirada de cada camarão foi pequena, cada amostra foi processada ou individualmente ou como um pool de hemolinfa de 2 a 5 animais submetidos às mesmas condições experimentais, até a obtenção de volume suficiente para as análises de medidas fisiológicas $(30 \mu \mathrm{L})$. As amostras foram armazenadas em tubos plásticos do tipo eppendorf com capacidade de $600 \mu \mathrm{L}$ e mantidas a $-20{ }^{\circ} \mathrm{C}$ para análises posteriores.

A osmolalidade $\left(\mathrm{mOsm} \mathrm{kg}{ }^{-1} \mathrm{H}_{2} \mathrm{O}\right)$ de cada amostra foi medida em alíquotas de $10 \mu \mathrm{L}$, utilizando-se um osmômetro de pressão de vapor (Wescor, modelo 5500). 
A concentração de $\mathrm{Cl}^{-}\left(\mathrm{mmol} \mathrm{L}^{-1}\right)$ foi medida em alíquotas de $10 \mu \mathrm{L}$, por microtitulação (Schales \& Schales, 1941, adaptado por Santos \& McNamara, 1996), em microtitulador (Metron Herisou, modelo E 485).

A concentração de $\mathrm{Na}^{+}\left(\mathrm{mmol} \mathrm{L} \mathrm{L}^{-1}\right)$ foi medida por absorção atômica (GBC, modelo 932AA) em $4 \mu \mathrm{L}$ de hemolinfa diluída em $40 \mathrm{~mL}$ de água destilada (1: 10.000).

\subsubsection{Disseccão das brânquias}

As brânquias dos camarões foram expostas após a remoção dos branquiostegitos, coletadas com o auxílio de microtesoura, colocadas em Trizol (Invitrogen) na porporção de 1: $10 \mathrm{massa} /$ volume e guardadas a $-80{ }^{\circ} \mathrm{C}$ até o uso em metodologias moleculares. Todas as brânquias foram coletadas e, como possuem massa pequena, foram processadas individualmente ou em pools de brânquias de 2 a 3 camarões submetidos às mesmas condições experimentais.

\section{$\underline{\text { 3.3 Metodologias de biologia molecular }}$}

\subsubsection{Purificação e quantificação de RNA total}

A extração de RNA total é baseada no método de isolamento de guanidina (Chamczynski \& Sacchi, 1987), sendo feita em Trizol (Invitrogen), conforme protocolo fornecido pelo fabricante. A extração do RNA foi feita em temperatura ambiente, em capela de exaustão devido à alta toxicidade do trizol, clorofórmio e isopropanol, com material autoclavado e manipulado com luvas limpas e higienizadas constantemente com álcool 70\%, em ambiente também limpo com álcool 70\% e livre de RNase. As brânquias foram maceradas com o auxílio de pistilos plásticos previamente higienizados com água oxigenada por pelo menos 30 minutos, lavados com etanol $70 \%$ e secos em estufa, e em todo o processo os pistilos são mantidos dentro de recipiente autoclavado ou estéril, como em tubo falcon novo de $50 \mathrm{~mL}$ de capacidade. Com os pistilos maceramos as brânquias manualmente até completa ou quase completa dissolução em trizol. As amostras contendo RNA total branquial extraído foram quantificadas em Fluorímetro Qubit ${ }^{\circledR} 2.0$ (Life Technologies) e armazenadas a $-80^{\circ} \mathrm{C}$.

Para garantir a pureza do RNA, $1 \mu \mathrm{g}$ de RNA total foi tratado com a enzima DNase I e submetido à reação de PCR convencional para amplificação do gene que codifica a proteína ribossomal L10 (PRL10, gene de referência interna), com primers genéricos desenhados a partir da sequência desse gene em Callinectes sapidus (AY822650) (Wynn et al., 2004), obtida no banco de dados National Center for Biotechnology Information (NCBI) GenBank 
(http://www.ncbi.nlm.nih.gov - Tabela 1). As reações de PCR, incluindo controles negativo e positivo, foram analisadas em gel de agarose, como diagnóstico da ausência de contaminação com DNA.

Tabela 1. Sequência dos primers utilizados na amplificação parcial do gene da proteína ribossomal L10 (PRL10_Cs_F e PRL10_Cs_R) (Wynn et al., 2004), em brânquias de Dilocarcinus pagei e de Macrobrachium jelskii.

\begin{tabular}{ccc}
\hline \hline Primer & Sequência & Amplicon (pb) \\
\hline PRL10_Cs_F & AAGAACTGCGGCAAGGACCAGTTCC 3' & \multirow{2}{*}{304} \\
PRL10_Cs_R & CGGTCAAACTTGGTAAAGCCCCACT 3' & \\
\hline \hline
\end{tabular}

O protocolo de amplificação foi:

1) Desnaturação inicial, $94{ }^{\circ} \mathrm{C}$ (3 min); 2) Desnaturação, $94{ }^{\circ} \mathrm{C}(30 \mathrm{~s})$; Pareamento, 55 ${ }^{\circ} \mathrm{C}$ (40 s); Extensão, $72{ }^{\circ} \mathrm{C}$ (50 s) - 40 ciclos; 3) Extensão final, $72{ }^{\circ} \mathrm{C}$ (10 min).

O produto da reação de PCR foi analisado por eletroforese em gel de agarose a $1 \%$ corado com Sybr Safe (Invitrogen), em tampão TBE (Tris-Borato, EDTA, pH 8.0). Para visualização do produto foi utilizado transiluminador de luz azul (Safe Imager ${ }^{\mathrm{TM}} 2.0$ BlueLight Transilluminator, Life Technologies), e os géis foram documentados em fotodocumentador Digimage System (Major Science). Nesse caso, não são esperados produtos de amplificação (bandas de DNA), já que o tratamento de RNA com a enzima DNase I elimina qualquer DNA contaminante que possa ter vindo durante a extração de RNA e que serviria como molde da reação de PCR, caso presente. Exemplos da ausência de DNA contaminante são mostrados após PCRs com amostras de D. pagei na Figura 8 e com amostras de M. jelkii na Figura 9.

Quando houve o aparecimento de bandas no gel, o tratamento foi refeito com menor quantidade de massa de RNA total, o que consequentemente teria menor quantidade de DNA contaminante, para que a enzima DNase I pudesse ser eficiente na degradação total do DNA, até ser detectada a pureza do RNA. É esperado o aparecimento de banda nas reações de controle positivo, as quais foram feitas com cDNA de Dilocarcinus pagei já verificado anteriormente em gel de agarose quanto ao sucesso de amplificação de PRL10. Não são esperadas bandas nas reações de controle negativo, as quais são feitas com água autoclavada ao invés de conterem RNA total tratado com DNase I. 


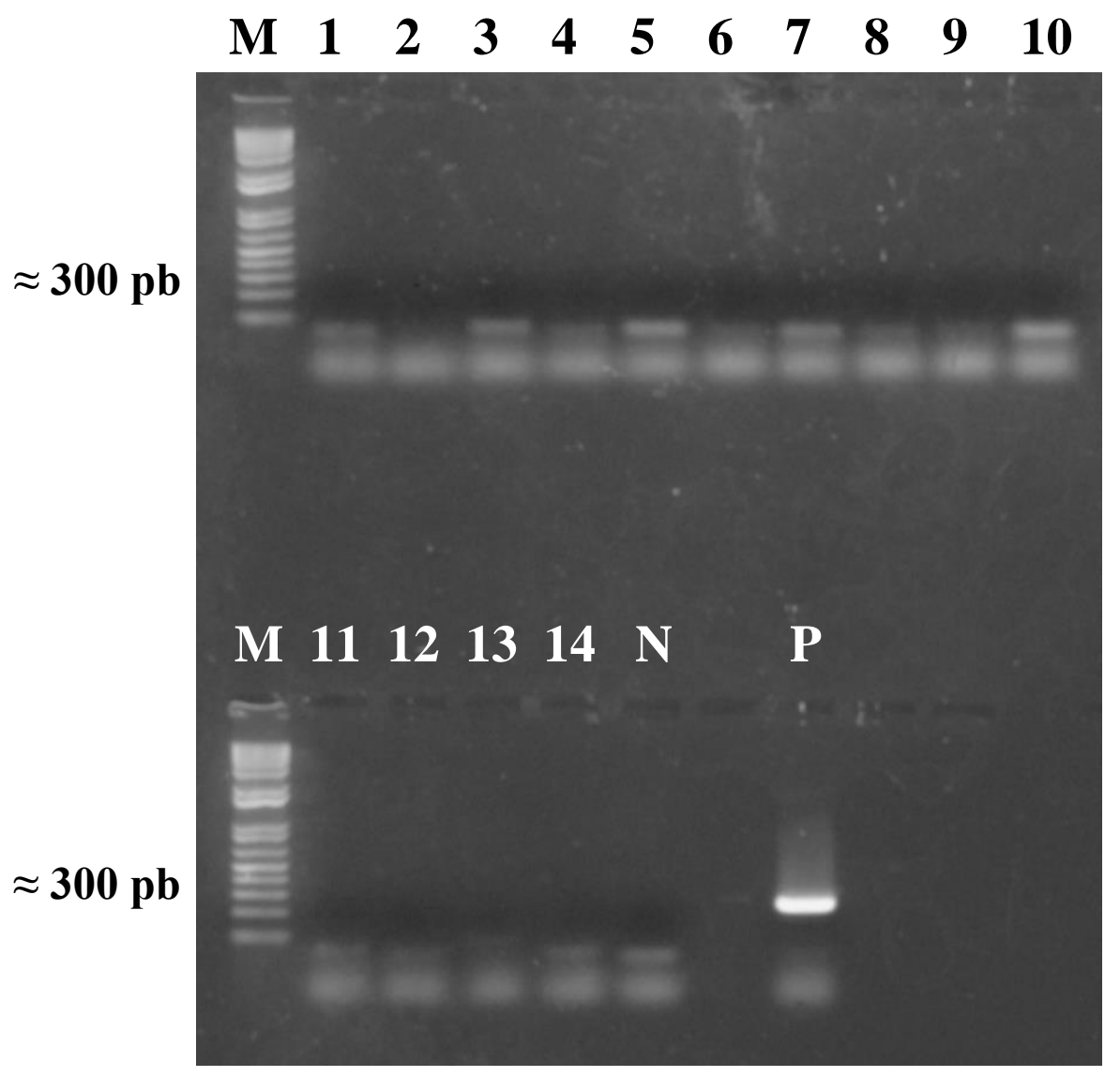

Figura 8. Visualização do produto das reações de PCR para PRL10 em amostras de RNA total de brânquias de D. pagei, após tratamento com DNase I. As reações foram verificadas por eletroforese em gel de agarose $1 \%$. Raias de 1 a 14, amostras de RNA. Verificar que não há produto, o que comprova a ausência de DNA contaminante junto ao RNA. N, controle negativo. P, controle positivo (reação feita com cDNA de Dilocarcinus pagei). M, marcador molecular 1 kb DNA Ladder Plus (Invitrogen).

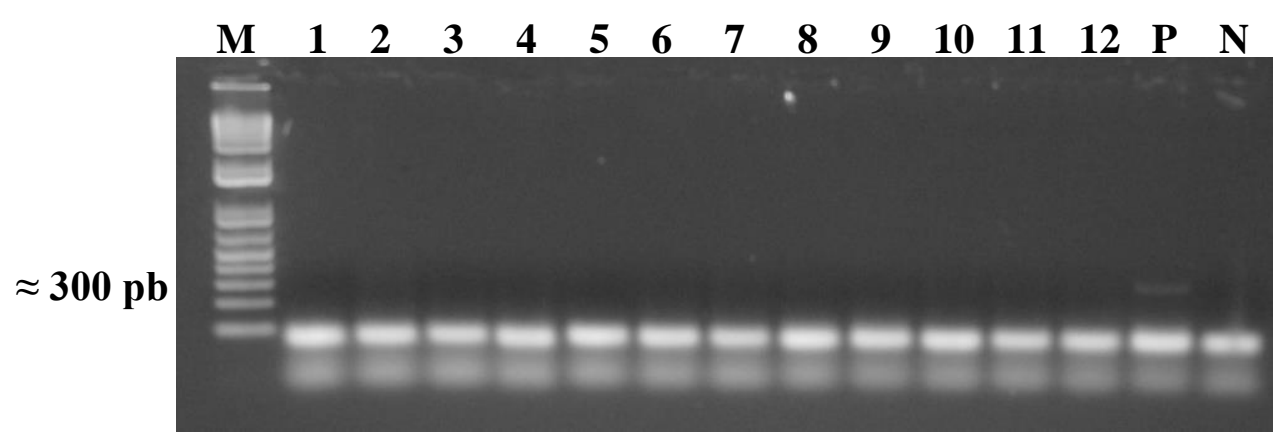

Figura 9. Visualização do produto das reações de PCR para PRL10 em amostras de RNA de M. jelskii, após tratamento com DNase I. As reações foram verificadas por eletroforese em gel de agarose 1\%. Raias de 1 a 12 , amostras de RNA. Verificar que não há produto, o que comprova a ausência de DNA contaminante junto ao RNA. N, controle negativo. P, controle positivo (reação feita com cDNA de Dilocarcinus pagei). M, marcador molecular 1 kb DNA Ladder Plus (Invitrogen). 


\subsubsection{Transcricão reversa dos mRNAs - producão de cDNA}

Verificada a pureza do RNA, foi realizada a reação de transcrição reversa de cada amostra para confecção de cDNA, visando análises de expressão gênica por qPCR (PCR quantitativa). A reação de transcrição reversa foi feita com o kit SuperScript III (Invitrogen), seguindo o protocolo do fabricante, modificado e otimizado por Faleiros et al. (2010).

Aproximadamente $300 \mathrm{ng}$ de RNA total, previamente tratados com DNase I, foram submetidos à reação de síntese de cDNA, processada em termociclador Veriti ${ }^{\text {TM }}$ (Applied Biosystems). Terminada a RT-PCR, as amostras de cDNA foram diluídas para a concentração final de $5 \mu \mathrm{g} / \mu \mathrm{L}$ e, posteriormente, avaliadas por reação de PCR para amplificação da PRL10, seguida de eletroforese, com os primers especificados na Tabela 1 e nas condições de amplificação citadas acima. Após a corrida da eletroforese em gel de agarose, verificou-se a presença de bandas como produto das reações, como prova da confecção de cDNA que constitui o molde da reação de PCR, conforme exemplos mostrados após PCR com amostras de $D$. pagei na Figura 10 e com amostras de $M$. jelkii na Figura 11. Essa verificação é importante, pois garante o sucesso da conversão de RNA em cDNA, para posterior avaliação da expressão gênica por qPCR. Nessa PCR diagnóstica, é esperada amplificação nas reações de controle positivo, mas não é esperada amplificação nas reações de controle negativo, como anteriormente já explicado. 


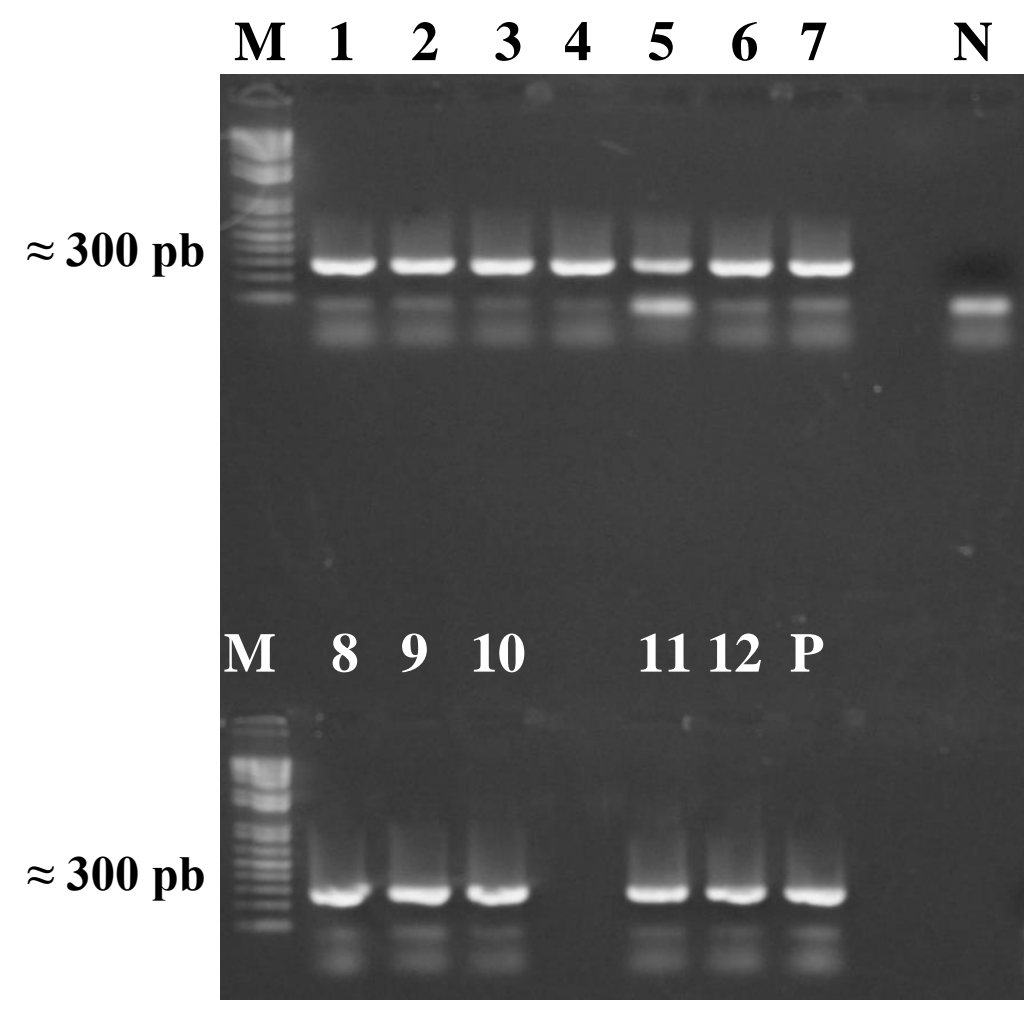

Figura 10. Visualização do produto das reações de PCR para PRL10 em amostras de cDNA de brânquias de $D$. pagei. As reações foram verificadas por eletroforese em gel de agarose 1\%. Raias de 1 a 12, amostras de cDNA. Observar o produto de 300 pares de base, confirmando a presença de DNA molde na reação. N, controle negativo. P, controle positivo (reação feita com cDNA de Dilocarcinus pagei previamente verificada). M, marcador de peso molecular $1 \mathrm{~kb}$ DNA Ladder Plus (Invitrogen).

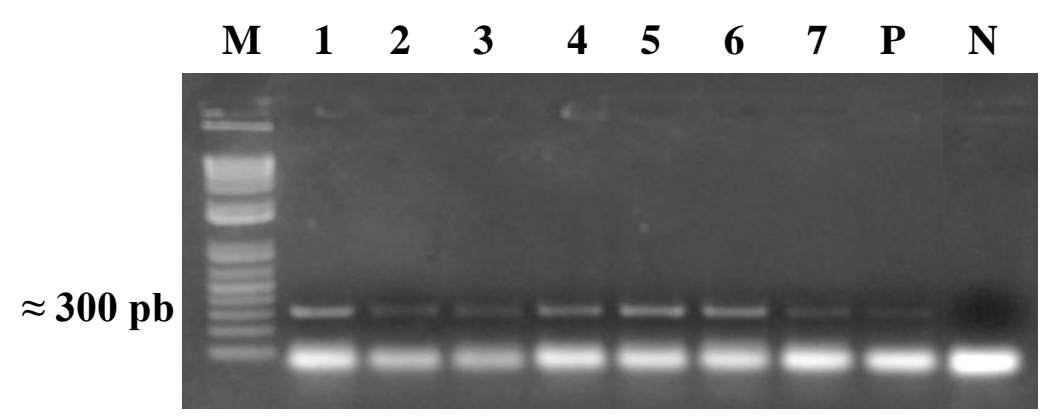

Figura 11. Visualização do produto das reações de PCR para PRL10 de M. jelskii em amostras de cDNA branquial. As reações foram verificadas por eletroforese em gel de agarose 1\%. Raias de 1 a 7 , amostras de cDNA. Observar o produto de 300 pares de base, confirmando a presença de DNA molde na reação. N, controle negativo. $\mathrm{P}$, controle positivo (reação feita com cDNA de Dilocarcinus pagei). M, marcador de peso molecular 1 kb DNA Ladder Plus (Invitrogen). 


\subsubsection{Clonagem e sequenciamento dos cDNAs de interesse}

\section{Amplificação, clonagem e análise da região codificadora dos genes de interesse em}

\section{Dilocarcinus pagei}

Visando analisar a expressão de genes que codificam proteínas ionotransportadoras que exercem importante papel na osmorregulação, realizamos clonagens e sequenciamentos de DNA, referentes à parte da região codificadora dos genes de interesse: i) a subunidade $\alpha$ da $\mathrm{Na}^{+} / \mathrm{K}^{+}$-ATPase; ii) a subunidade $\mathrm{B}$ da $\mathrm{V}\left(\mathrm{H}^{+}\right)$-ATPase; iii) o simportador $\mathrm{Na}^{+} / \mathrm{K}^{+} / 2 \mathrm{Cl}^{-}$; iv) e a proteína ribossomal L10 (PRL10), obtidas de brânquias de Dilocarcinus pagei. A obtenção da sequência inteira ou parcial de cada gene de interesse é essencial para a construção de primers específicos a serem utilizados na técnica de quantificação por PCR em tempo real (qPCR), para análise de expressão gênica.

Como as sequências gênicas parciais que codificam as proteínas ionotransportadoras $\mathrm{Na}^{+} / \mathrm{K}^{+}$-ATPase e $\mathrm{V}\left(\mathrm{H}^{+}\right)$-ATPase nas brânquias de D. pagei já existiam (Weihrauch et al., 2004) sob os códigos de acesso AF409119 e AF409118 do NCBI GenBank, apenas sequenciamos parte da região codificadora do gene PRL10 e do gene que codifica o simportador $\mathrm{Na}^{+} / \mathrm{K}^{+} / 2 \mathrm{Cl}^{-}$.

\section{PRL10}

O cDNA do gene PRL10 foi parcialmente amplificado por PCR convencional, utilizando o par de primers PRL10_Cs_F/PRL10_Cs_R descrito na Tabela 1, nas condições de amplificação previamente descritas (página 25). A amplificação resultou em um fragmento de aproximadamente $300 \mathrm{pb}$ a partir do cDNA branquial de D. pagei, conforme mostrado na Figura 12. 


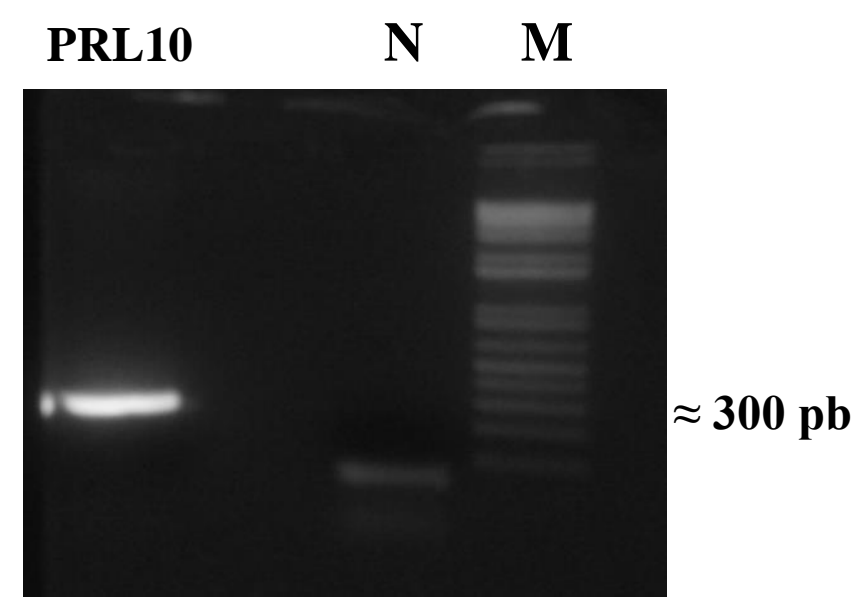

Figura 12. Análise da reação de PCR em gel de agarose 1\%, correspondente à amplificação da sequência parcial de PRL10 das brânquias de D. pagei $(\approx 300 \mathrm{pb})$. N, controle negativo (reação sem cDNA). M, marcador de peso molecular 1 kb DNA Ladder Plus (Life Technologies).

Após a corrida eletroforética, a banda fluorescente, correspondente ao fragmento de tamanho esperado, foi recortada do gel para purificação dos amplicons, por meio do kit PureLink Quick Gel Extract Kit (Invitrogen).

Dessa forma, o fragmento de interesse purificado foi clonado em vetor PCR 2.1-TOPO TA (Invitrogen), segundo protocolo descrito abaixo. Após a clonagem, foi inserido em E. coli DH5 $\alpha$ termocompetente, por transformação pelo método do choque térmico, resultando em algumas colônias isoladas em placas de Petri contendo meio LB-ágar, o antibiótico ampicilina, ao qual o vetor contém o gene de resistência, e agentes seletivos (IPTG e X-gal).

Duas colônias foram inoculadas em $3 \mathrm{~mL}$ de LB com ampicilina. Após crescimento da cultura, $1 \mu \mathrm{L}$ de cada foi utilizado em reação de PCR para PRL10, visando verificar a eficiência da clonagem. As reações foram submetidas à eletroforese em gel de agarose $1 \%$ (Figura 13), sendo que um único clone positivo foi escolhido para a extração do DNA plasmidial (vetor + inserto de interesse) e sequenciamento. 


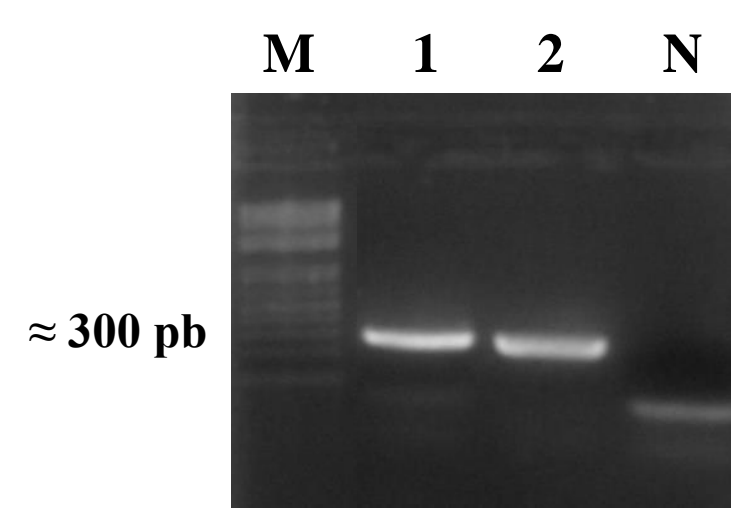

Figura 13. Visualização do produto das reações de PCR para PRL10 de D. pagei em culturas de bactérias. As reações foram verificadas por eletroforese em gel de agarose $1 \%$, e as raias 1 e 2 correspondem ao produto de PCR de duas colônias de bactérias diferentes, as quais contêm o vetor PCR 2.1-TOPO TA com a sequência de PRL10 de D. pagei. Observar que ambas estão positivas. N, controle negativo. M, marcador de peso molecular 1 kb DNA Ladder Plus (Life Technologies).

A sequência obtida para a proteína ribossomal L10 (PRL10) das brânquias de D. pagei foi analisada no programa Bioedit, e a confirmação da similaridade das sequências de nucleotídeos ou aminoácidos foi feita por comparação com outras sequências de PRL10 depositadas no NCBI GenBank, pelo programa BLAST. O aplicativo BLASTx traduziu a sequência obtida em uma sequência de aminoácidos nas suas seis possíveis Open Reading Frames (ORFs), acessando o banco de dados de proteínas. A sequência parcial obtida da região codificadora do gene PRL10 (251 pb, descontando-se a sequência dos primers) foi depositada no banco de dados do NCBI Genbank sob o número de acesso KT876051.

A sequência parcial do cDNA do gene PRL10 branquial de D. pagei (251 pb) é: >gi|949479301|gb|KT876051.1| Dilocarcinus pagei voucher LFC109 ribosomal protein L10 mRNA, partial cds

ACGTGCGAGTCCGGCTCCATCCCTTCCACGTCATCCGCATTAACAAGATGTTGTCGTGTGCTGGCGC TGACAGACTGCAAACAGGGATGCGAGGTGCCTTCGGCAAGCCCCAGGGCACAGTGGCTAGGGTTC AGATTGGCCAGCCCATCATGTCTGTCCGCACTCATGATCGCCACAAGGCCCATGTCATTGAGGCAT TGAGGAGAGCCAAGTTCAAGTACCCTGGGAGGCAAAAGATCTACGTCTCCCGC

A sequência deduzida de aminoácidos parciais da proteína ribossomal L10 branquial de D. pagei, usando a terminologia da IUPAC para aminoácidos por meio de uma letra, é: translation="VRVRLHPFHVIRINKMLSCAGADRLQTGMRGAFGKPQGTVARVQIGQPIMSVRTHDRHKA HVIEALRRAKFKYPGRQKIYVSR" 


\section{$\underline{\mathrm{Na}^{+} / \mathrm{K}^{+} / 2 \mathrm{Cl}^{-}}$}

Já o cDNA do gene que expressa o simportador $\mathrm{Na}^{+} / \mathrm{K}^{+} / 2 \mathrm{Cl}^{-}$foi parcialmente amplificado por PCR convencional com a enzima Platinum SuperFi DNA polimerase (Invitrogen), utilizando os primers descritos na Tabela 2, nas condições de amplificação descritas abaixo.

Esses primers foram construídos a partir da sequência que codifica o simportador $\mathrm{Na}^{+} / \mathrm{K}^{+} / 2 \mathrm{Cl}^{-}$em Eriocheir sinensis (Weihrauch \& Towle, 2000).

Tabela 2. Sequência dos primers utilizados na amplificação parcial do gene que expressa o simportador $\mathrm{Na}^{+} / \mathrm{K}^{+} / 2 \mathrm{Cl}^{-}\left(\mathrm{NKCC} \_\right.$Es_F e NKCC_Es_R), em brânquias de Dilocarcinus pagei.

\begin{tabular}{ccc}
\hline \hline Primer & Sequência & Amplicon (pb) \\
\hline NKCC_Es_F & GGCTACAAGGCAAACTGGCG 3' & \multirow{2}{*}{399} \\
NKCC_Es_R & GCCCTTCTTCTGTTTCCTCTTG 3' & \\
\hline \hline
\end{tabular}

O protocolo de amplificação foi:

1) Desnaturação inicial, $94{ }^{\circ} \mathrm{C}(3 \mathrm{~min})$; 2) Desnaturação, $94{ }^{\circ} \mathrm{C}(30 \mathrm{~s})$; Pareamento, 52 ${ }^{\circ} \mathrm{C}$ (40 s); Extensão, $72{ }^{\circ} \mathrm{C}$ (50 s) - 40 ciclos; 3) Extensão final, $72{ }^{\circ} \mathrm{C}$ (10 min).

O par de primers NKCC_Es_F/NKCC_Es_R (Tabela 2) amplificou um fragmento de aproximadamente $400 \mathrm{pb}$ a partir do cDNA branquial de D. pagei, conforme mostrado na Figura 14.

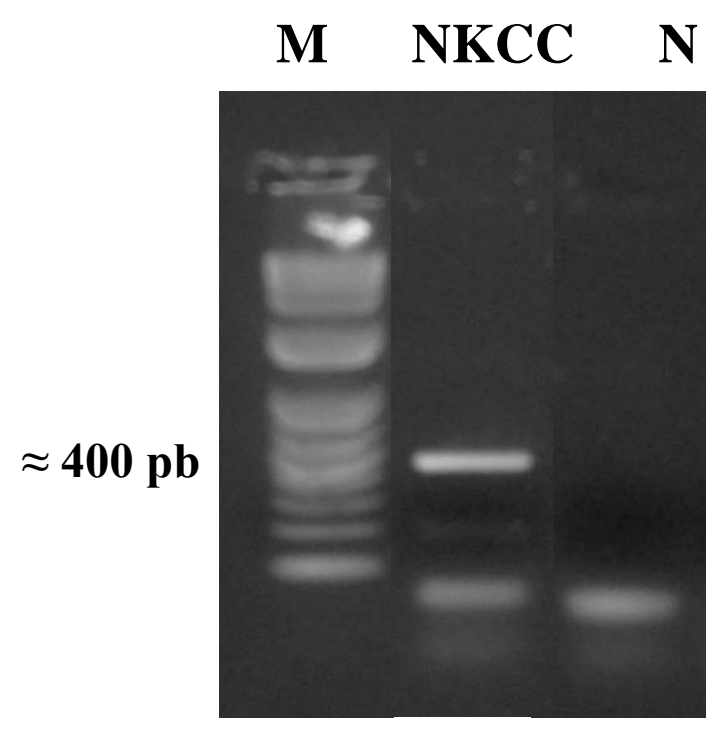

Figura 14. Análise da reação de $\mathrm{PCR}$ em gel de agarose $1 \%$, correspondente à amplificação da sequência parcial do gene que codifica o simportador $\mathrm{Na}^{+} / \mathrm{K}^{+} / 2 \mathrm{Cl}^{-}(\mathrm{NKCC})$ das brânquias de D. pagei $(\approx 400 \mathrm{pb})$. $\mathrm{N}$, controle negativo (reação sem cDNA). M, marcador de peso molecular 1 kb DNA Ladder Plus (Life Technologies). 
Após a corrida eletroforética, a banda fluorescente, correspondente ao fragmento de tamanho esperado, foi recortada do gel para purificação dos amplicons, por meio do kit PureLink Quick Gel Extract Kit (Invitrogen).

Dessa forma, o fragmento de interesse purificado foi clonado em vetor pJet 1.2/blunt (kit de clonagem ClonJet - Thermo Scientific), adequado para clonagem de fragmentos com extremidades abruptas (blunt), como todos os polimerizados por essa enzima, segundo protocolo descrito abaixo.

Posteriormente, foi inserido em E. coli DH5 $\alpha$ termocompetente, por transformação pelo método do choque térmico, resultando em algumas colônias isoladas em placas de Petri contendo meio LB-ágar e o antibiótico ampicilina, cuja a resistência é dada pelo vetor.

Três colônias foram inoculadas em $3 \mathrm{~mL}$ de LB com ampicilina. Após crescimento da cultura, $1 \mu \mathrm{L}$ de cada foi utilizado em reação de PCR para o simportador $\mathrm{Na}^{+} / \mathrm{K}^{+} / 2 \mathrm{Cl}^{-}$, visando verificar a eficiência da clonagem. As reações foram submetidas à eletroforese em gel de agarose 1\% (Figura 15), sendo que todos os clones analisados estavam positivos, embora apenas um tenha sido escolhido para a extração do DNA plasmidial (vetor + inserto de interesse) e sequenciamento.

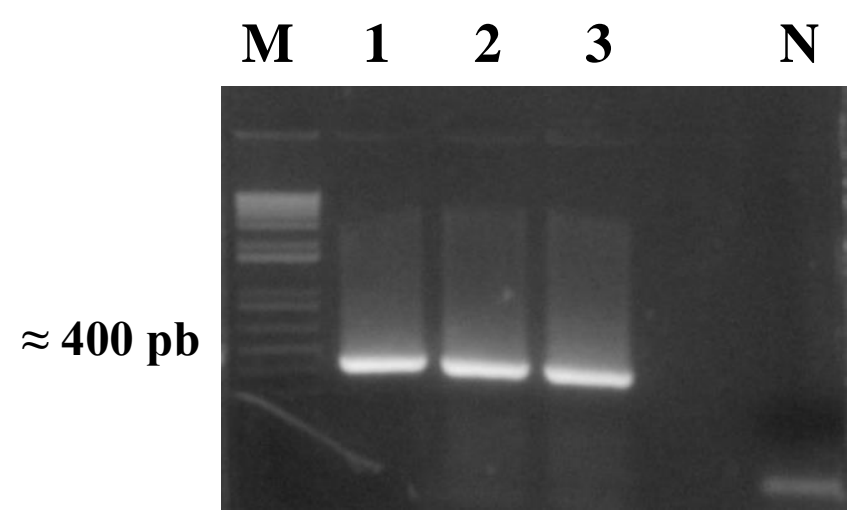

Figura 15. Visualização do produto das reações de PCR para o simportador $\mathrm{Na}^{+} / \mathrm{K}^{+} / 2 \mathrm{Cl}^{-}$de D. pagei em culturas de bactérias. As reações foram verificadas por eletroforese em gel de agarose 1\%, sendo que as raias 1, 2 e 3 correspondem ao produto de PCR de três colônias de bactérias diferentes, as quais contêm a região codificadora do simportador $\mathrm{Na}^{+} / \mathrm{K}^{+} / 2 \mathrm{Cl}^{-}$de D. pagei clonada no vetor pJet $1.2 /$ blunt. Observar que todas estão positivas. N, controle negativo. M, marcador de peso molecular 1 kb DNA Ladder Plus (Life Technologies).

A sequência parcial obtida para a região codificadora do simportador $\mathrm{Na}^{+} / \mathrm{K}^{+} / 2 \mathrm{Cl}^{-}$ expresso nas brânquias de $D$. pagei foi analisada no programa Bioedit, e a confirmação da similaridade das sequências de nucleotídeos ou aminoácidos foi feita por comparação com outras sequências do simportador $\mathrm{Na}^{+} / \mathrm{K}^{+} / 2 \mathrm{Cl}^{-}$depositadas no NCBI GenBank, pelo programa BLAST. O aplicativo BLASTx traduziu a sequência obtida em uma sequência de aminoácidos 
nas suas seis possíveis Open Reading Frames (ORFs), acessando o banco de dados de proteínas. A sequência parcial obtida da região codificadora do gene $\mathrm{Na}^{+} / \mathrm{K}^{+} / 2 \mathrm{Cl}^{-}(399 \mathrm{pb}$, descontando-se a sequência dos primers) foi depositada no banco de dados do Genbank sob o número de acesso KX894795.

A sequência parcial do cDNA do gene que codifica o simportador $\mathrm{Na}^{+} / \mathrm{K}^{+} / 2 \mathrm{Cl}^{-}$ branquial de D. pagei (399 pb) é:

>KX894795.1 Dilocarcinus pagei voucher LFC122 sodium-potassium-two chloride symporter mRNA, partial cds

CAAGTGTGACCCCATGGAGCTTAAGGCATATTTCAACACTCTTCATGAGGCATTGGACATGTACTTT GGTGTGATAATCCTGCGTGTGCCCCAAGGCCTTGACTACTCCCAGATAATTGAAGATGAGGACTCT CCTACCATCATGAATGGTAATGAGAGCAATATTACCCAGACTCCTGAGGACAAACCTGGACAGTCC ACTGCCAATCAGCTCACCCAGGATGGAACAGACAGCGAGGCCTCAACGCCACCAGGATCCCCACA AGTGGAGCGTTCACAAGCGGTGCAAGACGCTACAACACCAGACAGTAAGAAGCGCCGCACATCCC TGGCCAACTTGTTCAGGGGTCCAGGAGGTACAGAGCTGAGCAAGGAAGTCCTCAACAATATCACA ATGTT

A sequência deduzida de aminoácidos parciais do simportador $\mathrm{Na}^{+} / \mathrm{K}^{+} / 2 \mathrm{Cl}^{-}$branquial de D. pagei, usando a terminologia da IUPAC para aminoácidos por meio de uma letra, é: translation="KCDPMELKAYFNTLHEALDMYFGVIILRVPQGLDYSQIIEDEDSPTIMNGNESNITQTPEDK PGQSTANQLTQDGTDSEASTPPGSPQVERSQAVQDATTPDSKKRRTSLANLFRGPGGTELSKEVLNNIT M"

\section{Amplificação, clonagem e análise da região codificadora dos genes de interesse em} Macrobrachium jelskii

Para $M$. jelskii, não havia nenhuma das sequências de interesse depositadas no NCBI Genbank, então amplificamos parte das regiões de interesse a partir das brânquias desses camarões utilizando os primers descritos na Tabela 3, nas condições de amplificação descritas abaixo.

Os primers utilizados para amplificar a subunidade $\alpha$ da $\mathrm{Na}^{+} / \mathrm{K}^{+}$-ATPase (NaK_10F, NaK_16R, Towle et al., 2001) e a subunidade B da V-ATPase (HAT_F2 e HAT_R4, Weihrauch et al., 2001) são degenerados, ou seja, são formados por um conjunto de sequências, de forma a cobrir todas as possibilidades de nucleotídeos que não são muito conservados dentro da sequência de anelamento do primer, uma vez que esses primers foram desenhados baseados em sequências conservadas da subunidade $\alpha$ da $\mathrm{Na}^{+} / \mathrm{K}^{+}$-ATPase e da subunidade B da V-ATPase de várias espécies de crustáceos. Já os primers que amplificam 
parte da região codificadora do gene codificante da proteína ribossomal L10 (PRL10, gene de referência interna) foram desenhados a partir da sequência desse gene em Callinectes sapidus (AY822650) (Wynn et al., 2004). Por fim, os primers que amplificaram parte da região codificadora do simportador $\mathrm{Na}^{+} / \mathrm{K}^{+} / 2 \mathrm{Cl}^{-}$(NKCC_Mk_F1 e NKCC_Mk_R1) foram desenhados a partir da sequência desse gene em Macrobrachium koombooloomba (sequência ainda não depositada, gentilmente cedida pelos autores Rahi et al., 2017).

As reações de PCR, incluindo controles negativo e positivo, foram analisadas em gel de agarose, para diagnóstico da ausência de contaminação com DNA. Os produtos das reações de PCR foram avaliados por eletroforese em gel de agarose como previamente descrito.

Tabela 3. Sequências dos primers utilizados na amplificação das sequências parciais dos genes que expressam a subunidade $\alpha$ da $\mathrm{Na}^{+} / \mathrm{K}^{+}$-ATPase (NaK_10F e NaK_16R), a subunidade B da V(H $\mathrm{H}^{+}$-ATPase (HAT_F2 e HAT_R4), o simportador $\mathrm{Na}^{+} / \mathrm{K}^{+} / 2 \mathrm{Cl}^{-}$(NKCC_Mk_F1 e NKCC_Mk_R1) e PRL10 (PRL10_Cs_F e PRL10_Cs_R), em brânquias de Macrobrachium jelskii.

\begin{tabular}{|c|c|c|}
\hline Primer & Sequência & $\begin{array}{l}\text { Amplicon } \\
(\mathrm{pb})\end{array}$ \\
\hline $\begin{array}{l}\text { NaK_10F } \\
\text { NaK_16R }\end{array}$ & $\begin{array}{l}\text { 5' ATGACIGTIGCICAYATG 3', } \\
\text { 5' GRTGRTCICCIGTIACCAT 3' }\end{array}$ & 669 \\
\hline $\begin{array}{l}\text { NKCC_Mk_F1 } \\
\text { NKCC_Mk_R1 }\end{array}$ & $\begin{array}{l}\text { 5' ATTGCTGCTGCCACCTACAT 3', } \\
\text { 5' TTTGGGATAGCCACAGCAGG 3', }\end{array}$ & 455 \\
\hline $\begin{array}{l}\text { HAT_F2 } \\
\text { HAT_R4 }\end{array}$ & $\begin{array}{l}\text { 5' GCNATGGGNGTNAAYATGGA 3' } \\
\text { 5' TGNGTDATRTCRTCGTTNGG 3' }\end{array}$ & 392 \\
\hline $\begin{array}{l}\text { PRL10_Cs_F } \\
\text { PRL10_Cs_R }\end{array}$ & $\begin{array}{l}\text { 5' AAGAACTGCGGCAAGGACCAGTTCC 3' } \\
\text { 5' CGGTCAAACTTGGTAAAGCCCCACT 3' }\end{array}$ & 302 \\
\hline
\end{tabular}

O protocolo de amplificação foi:

1) Desnaturação inicial, $94{ }^{\circ} \mathrm{C}(3 \mathrm{~min})$; 2) Desnaturação, $94{ }^{\circ} \mathrm{C}(30 \mathrm{~s})$; Pareamento, 52 ${ }^{\circ} \mathrm{C}\left(\mathrm{Na}^{+} / \mathrm{K}^{+}\right.$-ATPase) $55^{\circ} \mathrm{C}\left(\mathrm{Na}^{+} / \mathrm{K}^{+} / 2 \mathrm{Cl}^{-}\right) 45^{\circ} \mathrm{C}\left(\mathrm{V}\left(\mathrm{H}^{+}\right)\right.$-ATPase) e $40{ }^{\circ} \mathrm{C}$ (PRL10) $(40 \mathrm{~s})$; Extensão, $72{ }^{\circ} \mathrm{C}(50 \mathrm{~s})$ - 40 ciclos; 3$)$ Extensão final, $72{ }^{\circ} \mathrm{C}$ (10 min). 


\section{PRL10}

O cDNA do gene PRL10 foi parcialmente amplificado por PCR convencional, utilizando os primers descritos na Tabela 1, nas condições de amplificação previamente descritas (página 25).

O par de primers PRL10_Cs_F/PRL10_Cs_R amplificou um fragmento de aproximadamente $300 \mathrm{pb}$ a partir do cDNA branquial de $M$. jelskii, conforme mostrado na Figura 16.

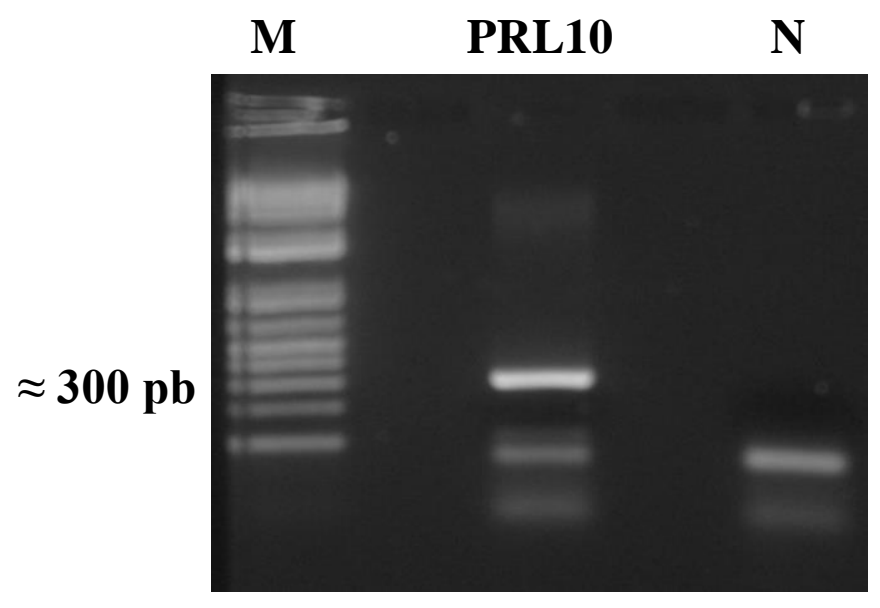

Figura 16. Análise da reação de PCR em gel de agarose $1 \%$, correspondente à amplificação da sequência parcial do gene que codifica PRL10 das brânquias de $M$. jelskii ( $\approx 300 \mathrm{pb}$ ). N, controle negativo (reação sem cDNA). M, marcador de peso molecular $1 \mathrm{~kb}$ DNA Ladder Plus (Life Technologies).

Após a corrida eletroforética, a banda fluorescente correspondente ao fragmento de tamanho esperado foi recortada do gel para purificação dos amplicons, por meio do kit PureLink Quick Gel Extract Kit (Invitrogen).

O fragmento de interesse purificado foi clonado em vetor PCR 2.1-TOPO TA (Invitrogen), segundo protocolo descrito abaixo. Posteriormente, foi inserido em E. coli DH5a ou DH10B termocompetentes, por transformação pelo método do choque térmico.

Após o crescimento de algumas colônias selecionadas, $2 \mu \mathrm{L}$ de cada foram utilizados em reação de PCR com os primers específicos, visando verificar a eficiência da clonagem e da transformação de bactérias. As reações foram submetidas à eletroforese em gel de agarose $1 \%$ (Figura 17). 


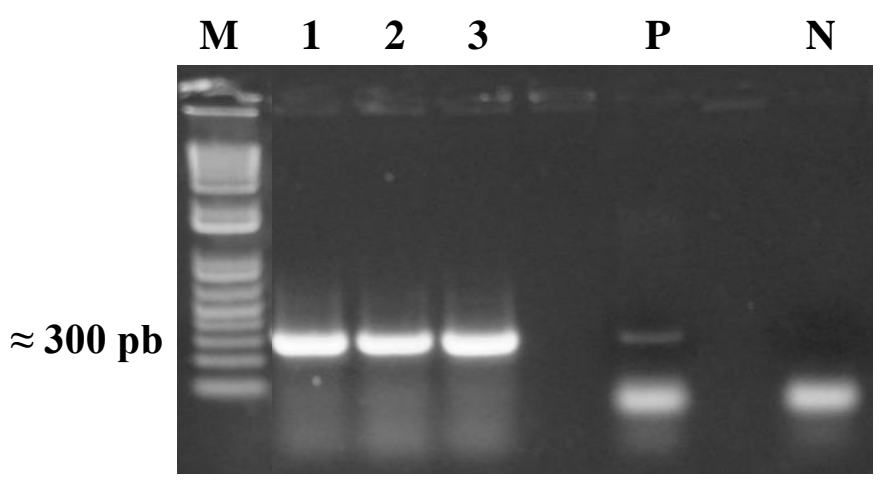

Figura 17. Visualização do produto das reações de PCR para PRL10 de M. jelskii em culturas de bactérias. As reações foram verificadas por eletroforese em gel de agarose $1 \%$, sendo que os números correspondem às raias onde há produtos de PCR de colônias de bactérias que contêm a sequência de interesse inserida no vetor PCR 2.1-TOPO TA. P, controle positivo (reação contendo cDNA de Dilocarcinus pagei). N, controle negativo. M, marcador de peso molecular $1 \mathrm{~kb}$ DNA Ladder Plus (Life Technologies).

As sequências obtidas para a proteína ribossomal L10 (PRL10) das brânquias de $M$. jelskii foram analisadas no programa Bioedit, e a confirmação da similaridade das sequências de nucleotídeos ou aminoácidos foi feita por comparação com outras sequências de PRL10 depositadas no NCBI GenBank, pelo programa BLAST. O aplicativo BLASTx traduziu a sequência obtida em uma sequência de aminoácidos nas suas seis possíveis Open Reading Frames (ORFs), acessando o banco de dados de proteínas. A sequência parcial obtida da região codificadora do gene PRL10 (251 pb, descontando-se a sequência dos primers) foi depositada no banco de dados do NCBI Genbank sob o número de acesso MG566062.

A sequência parcial do cDNA do gene PRL10 branquial de $M$. jelskii - (252 pb) é: >MG566062.1 Macrobrachium jelskii ribosomal protein L10 mRNA, partial cds ACATCCGTGTCAGGCTTCATCCTTTCCATGTCATCCGTATCAATAAAATGTTGTCGTGTGCTGGTGC TGATAGATTGCAGACTGGTATGCGAGGTGCCTTTGGTAAGCCCCAAGGCACAGTTGCACGTGTAAG AATTGGTCAGCCCATTATGTCTGTAAGGACCCACGATCGTCACAAGGCTCCCGTAGTCGAGGCCCT GAGAAGAGCAAAGTTCAAGTACCCCGGACGTCAGAAGATTTACATCTCGAGGA

A sequência deduzida de aminoácidos parciais da proteína ribossomal PRL10 branquial de $M$. jelskii, usando a terminologia da IUPAC para aminoácidos por meio de uma letra, é: translation="IRVRLHPFHVIRINKMLSCAGADRLQTGMRGAFGKPQGTVARVRIGQPIMSVRTHD RHKAPVVEALRRAKFKYPGRQKIYISR" 


\section{$\underline{\mathbf{V}\left(\mathbf{H}^{+}\right) \text {-ATPase }}$}

$\mathrm{O}$ cDNA do gene $\mathrm{V}\left(\mathrm{H}^{+}\right)$-ATPase foi parcialmente amplificado por PCR convencional, utilizando os primers descritos na Tabela 3, nas condições de amplificação previamente descritas (página 35).

O par de primers HAT_F2/HAT_R4 amplificou um fragmento de aproximadamente 400 pb a partir do cDNA branquial de M. jelskii, conforme mostrado na Figura 18.

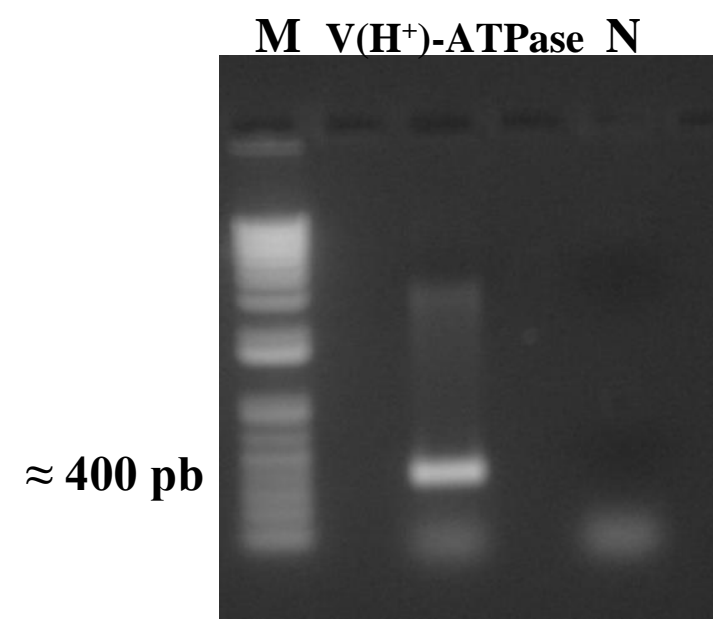

Figura 18. Análise da reação de PCR em gel de agarose 1\%, correspondente à amplificação da sequência parcial do gene que codifica a subunidade $\mathrm{B}$ da $\mathrm{V}\left(\mathrm{H}^{+}\right)$-ATPase das brânquias de $M$. jelskii $(\approx 400 \mathrm{pb})$. $\mathrm{N}$, controle negativo (reação sem cDNA). M, marcador de peso molecular 1 kb DNA Ladder Plus (Life Technologies).

Após a corrida eletroforética, a banda fluorescente, correspondente ao fragmento de tamanho esperado, foi recortada do gel para purificação dos amplicons, por meio do kit PureLink Quick Gel Extract Kit (Invitrogen).

O fragmento de interesse purificado foi clonado em vetor PCR 2.1-TOPO TA (Life Technologies), segundo protocolo descrito abaixo. Posteriormente, foi inserido em E. coli DH5 $\alpha$ ou DH10B termocompetentes, por transformação pelo método do choque térmico.

Após o crescimento de algumas colônias selecionadas, $2 \mu \mathrm{L}$ de cada foram utilizados em reação de PCR com os primers específicos, visando verificar a eficiência da clonagem e da transformação de bactérias. As reações foram submetidas à eletroforese em gel de agarose $1 \%$ (Figura 19). 


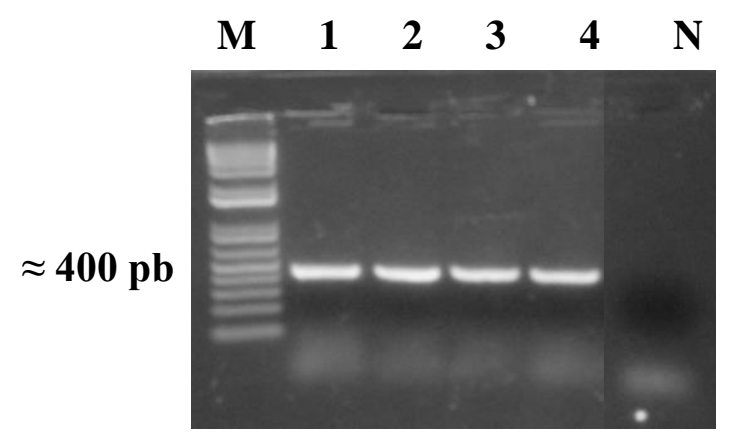

Figura 19. Visualização do produto das reações de PCR para $\mathrm{V}\left(\mathrm{H}^{+}\right)$-ATPase de M. jelskii em culturas de bactérias. As reações foram verificadas por eletroforese em gel de agarose $1 \%$, sendo que os números correspondem às raias onde há produtos de PCR de colônias de bactérias que contêm a sequência de interesse inserida no vetor PCR 2.1-TOPO TA. N, controle negativo. M, marcador de peso molecular 1 kb DNA Ladder Plus (Life Technologies).

As sequências obtidas para parte da região codificadora da subunidade $\mathrm{B}$ da $\mathrm{V}\left(\mathrm{H}^{+}\right)$ATPase, expressa em brânquias de $M$. jelskii foram analisadas no programa Bioedit, e a confirmação da similaridade das sequências de nucleotídeos ou aminoácidos foi feita por comparação com outras sequências já depositadas no NCBI GenBank, pelo programa BLAST. O aplicativo BLASTx traduziu as sequências obtidas em uma sequência de aminoácidos, acessando o banco de dados de proteínas. A sequência parcial obtida (352 pb, descontando-se a sequência dos primers) foi depositada no banco de dados do NCBI Genbank sob o número de acesso MG602347.

A sequência parcial do cDNA do gene que codifica a subunidade B da $\mathrm{V}\left(\mathrm{H}^{+}\right)$-ATPase branquial de $M$. jelskii - (352 pb) é:

>MG602347.1 Macrobrachium jelskii vacuolar H+-ATPase mRNA, partial cds

GACTGCTCGATTCTTCAAGCAGGACTTTGAAGAAAATGGTTCTATGGAAAATGTGTGCCTCTTCTTG AACTTGGCCAACGATCCCACAATTGAACGTATTATTACTCCTCGACTTGCCCTAACTACTGCAGAAT ATCTTGCCTACCAGTGCGAGAAACATGTTCTCATCATCCTGACTGATATGTCTTCATATGCAGAAGC TTTGCGAGAGGTATCAGCTGCTCGTGAAGAAGTGCCAGGTAGACGTGGTTTCCCAGGTTACATGTA CACTGATTTGGCTACTATTTATGAACGTGCCGGTCGAGTAGAAGGAAGACAAGGGTCCATCACACA GATTCCTATTTTGACTATG

A sequência deduzida de aminoácidos parciais da subunidade $\mathrm{B}$ da $\mathrm{V}\left(\mathrm{H}^{+}\right)$-ATPase branquial de $M$. jelskii, usando a terminologia da IUPAC para aminoácidos por meio de uma letra, é:

translation="TARFFKQDFEENGSMENVCLFLNLANDPTIERIITPRLALTTAEYLAYQCEKHVLIILTDMSS YAEALREVSAAREEVPGRRGFPGYMYTDLATIYERAGRVEGRQGSITQIPILTM” 


\section{$\underline{\mathrm{Na}^{+} / \mathrm{K}^{+} \text {-ATPase }}$}

$\mathrm{O}$ cDNA do gene $\mathrm{Na}^{+} / \mathrm{K}^{+}$-ATPase foi parcialmente amplificado por PCR convencional, utilizando os primers descritos na Tabela 3, nas condições de amplificação previamente descritas (página 35).

O par de primers NaK_10F/ NaK_16R amplificou um fragmento de aproximadamente 700 pb a partir do cDNA branquial de M. jelskii, conforme mostrado na Figura 20.

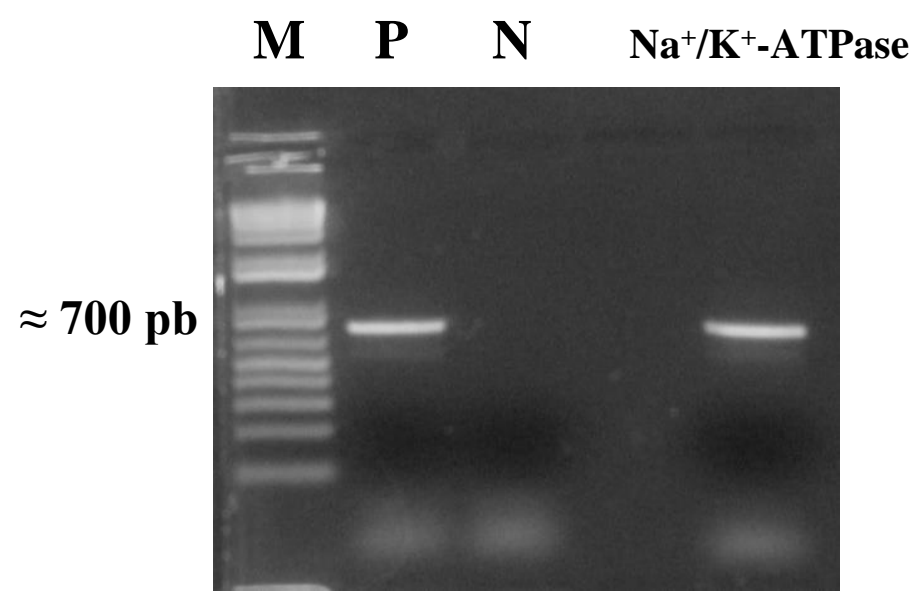

Figura 20. Análise da reação de PCR em gel de agarose 1\%, correspondente à amplificação da sequência parcial do gene que codifica a subunidade $\alpha \mathrm{da} \mathrm{Na}^{+} / \mathrm{K}^{+}$-ATPase das brânquias de $M$. jelskii $(\approx 700 \mathrm{pb})$. $\mathrm{P}$, controle positivo (reação feita com cDNA de D. pagei). N, controle negativo (reação sem cDNA). M, marcador de peso molecular $1 \mathrm{~kb}$ DNA Ladder Plus (Life Technologies).

Após a corrida eletroforética, a banda fluorescente, correspondente ao fragmento de tamanho esperado, foi recortada do gel para purificação dos amplicons, por meio do kit PureLink Quick Gel Extract Kit (Invitrogen).

O fragmento de interesse purificado foi clonado em vetor PCR 2.1-TOPO TA (Life Technologies), segundo protocolo descrito abaixo. Posteriormente, foi inserido em E. coli DH5 $\alpha$ termocompetente, por transformação pelo método do choque térmico.

Após o crescimento de algumas colônias selecionadas, $2 \mu \mathrm{L}$ de cada foram utilizados em reação de PCR com os primers específicos, visando verificar a eficiência da clonagem e da transformação de bactérias. As reações foram submetidas à eletroforese em gel de agarose $1 \%$ (Figura 21). 


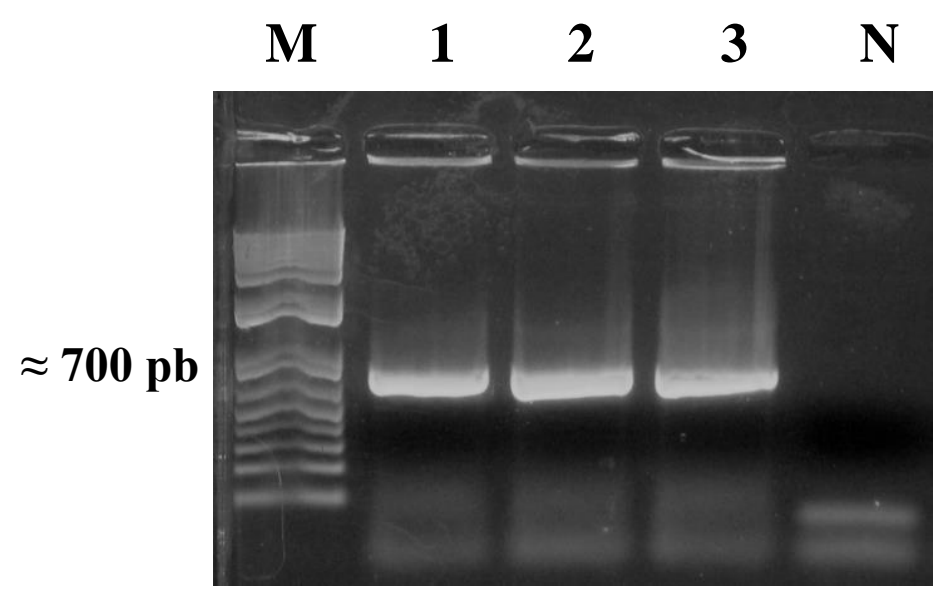

Figura 21. Visualização do produto das reações de PCR para $\mathrm{Na}^{+} / \mathrm{K}^{+}$-ATPase de $M$. jelskii em culturas de bactérias. As reações foram verificadas por eletroforese em gel de agarose $1 \%$, sendo que os números correspondem às raias onde há produtos de PCR de colônias de bactérias que contêm a sequência de interesse inserida no vetor PCR 2.1-TOPO TA. N, controle negativo. M, marcador de peso molecular 1 kb DNA Ladder Plus (Life Technologies).

A sequência obtida para parte da região codificadora da subunidade $\alpha$ da $\mathrm{Na}^{+} / \mathrm{K}^{+}$ATPase expressa em brânquias de $M$. jelskii foi analisada no programa Bioedit, e a confirmação da similaridade das sequências de nucleotídeos ou aminoácidos foi feita por comparação com outras sequências da subunidade $\alpha$ da $\mathrm{Na}^{+} / \mathrm{K}^{+}$-ATPase depositadas no NCBI GenBank, pelo programa BLAST. O aplicativo BLASTx traduziu a sequência obtida em uma sequência de aminoácidos nas suas seis possíveis Open Reading Frames (ORFs), acessando o banco de dados de proteínas. A sequência parcial obtida da região codificadora do gene da subunidade $\alpha$ da $\mathrm{Na}^{+} / \mathrm{K}^{+}$-ATPase (669 pb, descontando-se a sequência dos primers) foi depositada no banco de dados do NCBI Genbank sob número de acesso MF615389.

A sequência parcial do cDNA do gene que codifica a subunidade $\alpha$ da $\mathrm{Na}^{+} / \mathrm{K}^{+}$-ATPase branquial de $M$. jelskii - (669 pb) é:

>MF615389.1 Macrobrachium jelskii voucher LFC125 sodium-potassium adenosine triphosphatase mRNA, partial cds

TGGTTTGACAATACCATTATTGAGGCAGATACCTCTGAAGATCAATCAGGTTGCCAGTATGACAAG ACATCAGAAGGATGGAAAACACTCTCCAGAATTGCTGCTCTATGCAACAGGGCTGAATTTAAAACA GGTCAAGAAGATGTTCCCATCCTGAAGCGTGAAGTTAATGGTGATGCCTCTGAAGCTGCTCTGTTA AAATGTGTTGAATTGGCTTGCGGTGATGTTAAGGGCTGGCGTGCACGAAACAAGAAGGTATGCGA GATTCCCTTCAATTCCACCAACAAATACCAAGTATCTATTCACGAAACTGAAGACAAGAACGACCC ACGATACCTCCTTGTCATGAAGGGAGCTCCTGAAAGAATATTGGAAAAATGTACGACCATTTTCAT TAACGGCCAAGAAGAAGAACTGGATGAAGAAACGAAGGAAGCTTTCAACAATGCTTACCTTGAAT TGGGAGGTCTTGGTGAGCGTGTACTTGGATTTTGTGATTACTGCCTGCCCTCCGACAAATATCCCCT 
TGGCTATCCCTTTGATGCCGACAACGCAAACTTCCCCGTTCATGGGCTCCGATTTGTAGGTTTGATG TCTATGATTGATCCTCCCAGAGCTGCTGTACCTGATGCTGTAGCCAAATGCCGATCTGCTGGTATTA AGGTTATC

A sequência deduzida de aminoácidos parciais da subunidade $\alpha$ da $\mathrm{Na}^{+} / \mathrm{K}^{+}$-ATPase branquial de $M$. jelskii, usando a terminologia da IUPAC para aminoácidos por meio de uma letra, é:

translation="WFDNTIIEADTSEDQSGCQYDKTSEGWKTLSRIAALCNRAEFKTGQEDVPILKREVNGDAS EAALLKCVELACGDVKGWRARNKKVCEIPFNSTNKYQVSIHETEDKNDPRYLLVMKGAPERILEKCTTI FINGQEEELDEETKEAFNNAYLELGGLGERVLGFCDYCLPSDKYPLGYPFDADNANFPVHGLRFVGLM SMIDPPRAAVPDAVAKCRSAGIKVI"

\section{$\underline{\mathrm{Na}^{+} / \mathrm{K}^{+} / 2 \mathrm{Cl}^{-}}$}

$\mathrm{O}$ cDNA do gene $\mathrm{Na}^{+} / \mathrm{K}^{+} / 2 \mathrm{Cl}^{-}$foi parcialmente amplificado por PCR convencional, utilizando os primers descritos na Tabela 3, nas condições de amplificação previamente descritas (página 35).

O par de primers NKCC_Mk_F1/NKCC_Mk_R1 amplificou um fragmento de aproximadamente $450 \mathrm{pb}$ a partir do cDNA branquial de $M$. jelskii, conforme mostrado na Figura 22.

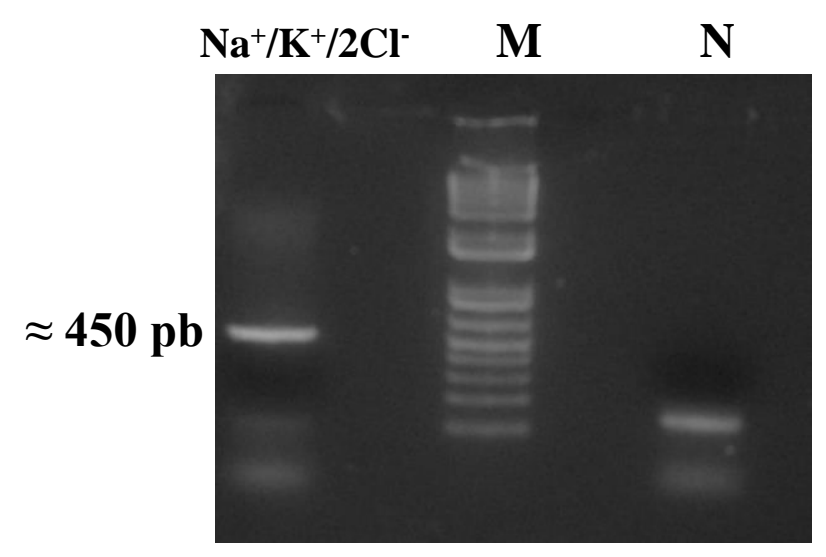

Figura 22. Análise da reação de PCR em gel de agarose 1\%, correspondente à amplificação da sequência parcial do gene que codifica $\mathrm{Na}^{+} / \mathrm{K}^{+} / 2 \mathrm{Cl}^{-}$das brânquias de $M$. jelskii $(\approx 450 \mathrm{pb})$. N, controle negativo (reação sem cDNA). M, marcador de peso molecular 1 kb DNA Ladder Plus (Life Technologies).

Após a corrida eletroforética, a banda fluorescente, correspondente ao fragmento de tamanho esperado, foi recortada do gel para purificação dos amplicons, por meio do kit PureLink Quick Gel Extract Kit (Invitrogen). 
O fragmento de interesse purificado foi clonado em vetor PCR 2.1-TOPO TA (Life Technologies), conforme protocolo descrito abaixo. Posteriormente, foi inserido em E. coli DH5 $\alpha$ termocompetente, por transformação pelo método do choque térmico.

Após o crescimento de algumas colônias selecionadas, $2 \mu \mathrm{L}$ de uma delas foram utilizados em reação de PCR com os primers específicos, visando verificar a eficiência da clonagem e da transformação de bactérias. A reação foi submetida à eletroforese em gel de agarose $1 \%$ (Figura 23).

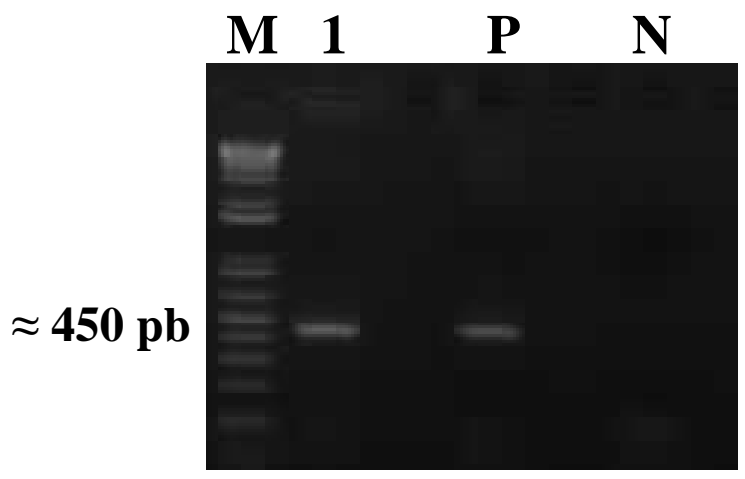

Figura 23. Visualização do produto da reação de PCR para $\mathrm{Na}^{+} / \mathrm{K}^{+} / 2 \mathrm{Cl}^{-}$de $M$. jelskii em culturas de bactérias. As reações foram verificadas por eletroforese em gel de agarose $1 \%$, sendo que o número 1 corresponde à raia onde há produtos de PCR de colônia de bactéria que contém a sequência de interesse inserida no vetor PCR 2.1TOPO TA. P, controle positivo (cDNA de Dilocarcinus pagei). N, controle negativo. M, marcador de peso molecular $1 \mathrm{~kb}$ DNA Ladder Plus (Life Technologies).

As sequências obtidas para parte da região codificadora do simportador $\mathrm{Na}^{+} / \mathrm{K}^{+} / 2 \mathrm{Cl}^{-}$, expressa em brânquias de $M$. jelskii foram analisadas no programa Bioedit, e a confirmação da similaridade das sequências de nucleotídeos ou aminoácidos foi feita por comparação com outras sequências já depositadas no NCBI GenBank, pelo programa BLAST. O aplicativo BLASTx traduziu as sequências obtidas em uma sequência de aminoácidos, acessando o banco de dados de proteínas. A sequência parcial obtida (415bp, descontando-se a sequência dos primers) foi depositada no banco de dados do NCBI Genbank sob número de acesso MG566061.

A sequência parcial do cDNA do gene que codifica o simportador $\mathrm{Na}^{+} / \mathrm{K}^{+} / 2 \mathrm{Cl}^{-}$branquial de $M$. jelskii - (415 pb) é:

>Macrobrachium jelskii sodium-potassium-two chloride symporter mRNA, partial cds ATCCTTCAGATCACCAGAGAGATTAGCACCAGCAACAATTCCAGTTACAGCAGGGAAGAAGACAC CAAACACACTGAAAATGTTCTGATTGGTCCCTTCAAATCTACGATAGTCAGCTATCACGTTTTCCTT TATGACTTCAAGATTGAAGCCTAAGAATCCCTGAGCTTCTTCTTCTGTGGAGGTTGGACCAATGAAT 
GTTCCAACGATGAAGTCTATCTGTGACCCGATCAGCAGAAACAGGAGACCCATCTGGACCCTGGTG ACCCAATCCATGCCAACAATAGCAAGAGCTAACACTGCTATCAAAGTGACAGTGCCGACAACTCTC GTGTCGTTAACTCCACCGTCAATTATCGTTGTACCGTCAAATTCATATTTCAACAAATCCTTGAGGG AATCGCAGAAACCAATG

A sequência deduzida de aminoácidos parciais do simportador $\mathrm{Na}^{+} / \mathrm{K}^{+} / 2 \mathrm{Cl}^{-}$branquial de M. jelskii, usando a terminologia da IUPAC para aminoácidos por meio de uma letra, é: translation="IGFCDSLKDLLKYEFDGTTIIDGGVNDTRVVGTVTLIAVLALAIVGMDWVTRVQMGLLFLL IGSQIDFIVGTFIGPTSTEEEAQGFLGFNLEVIKENVIADYRRFEGTNQNIFSVFGVFFPAVTGIVAGANLS GDLKD”

\section{Aspectos gerais sobre as clonagens das sequências de interesse}

Os amplicons purificados correspondentes às regiões codificadoras parciais dos genes de interesse nas duas espécies aqui analisadas foram clonados individualmente no vetor PCR 2.1 TOPO TA (Invitrogen), com exceção do amplicon purificado que corresponde à região codificadora parcial do simportador $\mathrm{Na}^{+} / \mathrm{K}^{+} / 2 \mathrm{Cl}^{-}$de brânquias de $D$. pagei que, por ter sido amplificado com a enzima Platinum SuperFi DNA polimerase, foi clonado no vetor pJet 1.2/blunt (kit de clonagem ClonJet - Thermo Scientific). Posteriormente, bactérias Escherichia coli DH5 $\alpha$ ou DH10B termocompetentes foram transformadas com cada construção plasmidial, pelo método de choque térmico. Para tal, as bactérias foram misturadas ao plasmídio em tubo eppendorf, e, então, levadas a $42^{\circ} \mathrm{C}$ por 50 segundos, para abertura de poros na membrana plasmática e entrada do plasmídeo, seguidos de 2 minutos em gelo (para fechamento dos poros).

Para verificação e escolha dos transformantes positivos contendo o vetor TOPO TA com o fragmento de interesse, as colônias foram cultivadas em meio LB agar, contendo o antibiótico ampicilina a $100 \mu \mathrm{g} / \mathrm{mL}$, cuja resistência é conferida por esse plasmídeo, e os agentes seletivos X-Gal (100 $\mu \mathrm{g} / \mathrm{mL})$ e IPTG $(4 \mu \mathrm{g} / \mathrm{mL})$. As colônias azuis mostram atividade do gene lacZ, indicando que o plasmídeo contido na colônia de bactérias está vazio. Como o sítio de clonagem do plasmídeo está inserido dentro do gene lacZ, as colônias brancas indicam ausência de atividade desse gene e, portanto, a presença de algum inserto dentro do plasmídeo. Assim, as colônias brancas foram utilizadas como molde de reações de PCR convencional, realizadas com os primers descritos nas Tabelas 1 e 3 de acordo com a sequência gênica a ser amplificada, e seguiu-se à eletroforese em gel de agarose, visando a confirmação da presença do inserto. 
Para verificação e escolha dos transformantes positivos contendo o vetor pJET 1.2/blunt com o fragmento do simportador $\mathrm{Na}^{+} / \mathrm{K}^{+} / 2 \mathrm{Cl}^{-}$branquial de $D$. pagei, as colônias foram cultivadas em meio LB agar, contendo o antibiótico ampicilina a $100 \mu \mathrm{g} / \mathrm{mL}$, cuja resistência é conferida pelo plasmídeo. Uma vez que não há o gene lacZ na arquitetura do pJet 1.2/blunt, os agentes seletivos X-Gal e IPTG não foram utilizados. Assim sendo, todas as colônias, sejam positivas ou negativas, são brancas. Selecionamos algumas delas como moldes de reações de PCR convencional, realizadas com os primers descritos para o simportador $\mathrm{Na}^{+} / \mathrm{K}^{+} / 2 \mathrm{Cl}^{-}$(Tabela 2, página 32). As reações foram submetidas à eletroforese em gel de agarose, visando à confirmação da presença do inserto.

\section{Sequenciamento e análise das sequências obtidas}

As colônias de bactérias que continham as sequências de tamanhos esperados foram cultivadas em meio LB com o antibiótico ampicilina a $100 \mu \mathrm{g} / \mathrm{mL}$. O DNA plasmidial foi extraído da cultura e purificado com o PureLink Quick Plasmid Miniprep Kit (Invitrogen), sendo, posteriormente, submetido ao sequenciamento pelo método de incorporação de dideoxinucleotídeos (Sanger et al., 1977). O sequenciamento foi feito pela Faculdade de Ciências Farmacêuticas de Ribeirão Preto, em sequenciador 3500 Genetic Analyzer (Life Technologies).

As análises das sequências dos clones de cDNA foram realizadas pelo programa Bioedit (Hall, 1999). Posteriormente, as sequências obtidas foram analisadas com o aplicativo BLAST (http://www.ncbi.nih.gov/BLAST/) (Altschul et al., 1990), o qual detecta regiões de similaridade entre sequências de nucleotídeos ou aminoácidos e as compara com sequências já depositadas no NCBI GenBank (http://www.ncbi.nlm.nih.gov), calculando um valor de porcentagem de identidade.

Para determinar a sequência deduzida de aminoácidos correspondente ao fragmento de nucleotídeos sequenciado, utilizamos o aplicativo BLASTx, que compara a sequência de nucleotídeos de um fragmento específico, traduzido-a em uma sequência de aminoácidos nas suas seis possíveis Open Reading Frames (ORFs), acessando o banco de dados de proteínas.

As sequências gênicas parciais da proteína ribossomal L10 (PRL10) e do simportador $\mathrm{Na}^{+} / \mathrm{K}^{+} / 2 \mathrm{Cl}^{-}$de brânquias de D. pagei foram depositadas no NCBI GenBank, sob os números de acesso KT876051 e KX894795, respectivamente.

As sequências gênicas parciais da subunidade $\alpha$ da $\mathrm{Na}^{+} / \mathrm{K}^{+}$-ATPase, do simportador $\mathrm{Na}^{+} / \mathrm{K}^{+} / 2 \mathrm{Cl}^{-}$, da subunidade $\mathrm{B}$ da $\mathrm{V}\left(\mathrm{H}^{+}\right)$-ATPase e da proteína PRL10 de brânquias de $M$. 
jelskii foram depositadas no NCBI GenBank sob os números de acesso MF615389, MG566061, MG602347 e MG566062, respectivamente.

\subsubsection{Análises quantitativas por PCR em tempo real (qPCR)}

\section{Desenho de primers}

As sequências de interesse desse estudo, encontradas nas brânquias das espécies $D$. pagei e $M$. jelskii, foram analisadas para a escolha de primers, visando avaliar a expressão gênica por PCR quantitativo (qPCR).

No laboratório, já havia pares de primers para qPCR dessas regiões, porém desenhadas a partir das sequências branquiais de outras espécies de caranguejos e camarões. Como as sequências codificadoras parciais de interesse são parecidas entre algumas espécies de caranguejos e entre os camarões palemonídeos, foram feitos testes de eficiência dos primers, cujos resultados permitiram a utilização de alguns desses pares de primers já disponíveis para a qPCR de alguns dos genes de interesse das duas espécies desse estudo.

Em outros casos, novos primers foram desenhados a partir das sequências específicas de D. pagei ou M. jelskii, com o auxílio do aplicativo on-line Primer-BLAST (http://www.ncbi.nlm.nih.gov/tools/primer-blast/). Os critérios para o desenho dos primers foram: amplificar um fragmento entre 75 e $150 \mathrm{pb}$; apresentar temperatura de melting (Tm) entre 59-62 ${ }^{\circ} \mathrm{C}$; e conter $40-60 \%$ de nucleotídeos C e G. Primers que apresentassem elevados graus de auto-complementariedade e capacidade de formar dímeros foram evitados, e a estabilidade das extremidades 3' e 5' (máximo $\Delta \mathrm{G}$ - energia necessária para quebrar as pontes de hidrogênio das 5 primeiras bases de cada extremidade) foi analisada, sendo que quanto maior a estabilidade, maior a eficiência do primer (Thornton \& Basu, 2010).

Dessa forma, os primers utilizados para a realização da expressão gênica quantitativa dos genes de interesse, em brânquias de D. pagei, estão descritos na Tabela 4. Os primers para análise da expressão gênica quantitativa do simportador $\mathrm{Na}^{+} / \mathrm{K}^{+} / 2 \mathrm{Cl}^{-}$(NKCC_Dp_F e NKCC_Dp_R), da subunidade B da V(H+)-ATPase (V-ATPase_Dp_F e V-ATPase_Dp_R) e de PRL10 (PRL10_Dp_F e PRL10_Dp_R) foram desenhados a partir de sequências de nucleotídeos branquiais de Dilocarcinus pagei. Os primers para qPCR da subunidade $\alpha$ da $\mathrm{Na}^{+} / \mathrm{K}^{+}$-ATPase (NaK_Ucag_F e NaK_R) foram desenhados a partir de sequências de caranguejos do gênero $U c a$, descritas no relatório de pós-doutorado de Rogério Faleiros (dados não publicados). 
Tabela 4. Sequência dos primers utilizados na qPCR, após validação da eficiência para os genes que expressam a PRL10 (PRL10_Dp_F e PRL10_Dp_R), a subunidade $\square \square$ da $\mathrm{Na}^{+} / \mathrm{K}^{+}-\mathrm{ATPase}$ (NaK_Ucag_F e NaK_R), a subunidade B da V(H+)-ATPase (V-ATPase_Dp_F e V-ATPase_Dp_R) e o simportador $\mathrm{Na}^{+} / \mathrm{K}^{+} / 2 \mathrm{Cl}^{-}$ (NKCC_Dp_F e NKCC_Dp_R), em brânquias Dilocarcinus pagei.

\begin{tabular}{ccc}
\hline Primer & Sequência & $\begin{array}{c}\text { Amplicon } \\
(\mathrm{pb})\end{array}$ \\
\hline PRL10_Dp_F & 5' ATCATGTCTGTCCGCACTCAT 3' & $79 \mathrm{pb}$ \\
PRL10_Dp_R & 5' CAGGGTACTTGAACTTGGCTC 3' & \\
& & \\
NaK_Ucag_F & 5' CAACCGTGCTGAGTTCAAGA 3' & $99 \mathrm{pb}$ \\
NaK_Ucag_R & 5' TCCACACACTTCAGCAGAGC 3' & \\
& & \\
V-ATPase_Dp_F & 5' AGCTGAGTACCTTGCCTACC 3' & $80 \mathrm{pb}$ \\
V-ATPase_Dp_R & 5' GCAGGGCTTCAGCATAAGAA 3' & \\
& & \\
NKCC_Dp_F & 5' ACGCTACAACACCAGACAGT 3' & $82 \mathrm{pb}$ \\
NKCC_Dp_R & 5' TTGCTCAGCTCTGTACCTCC 3' & \\
\hline
\end{tabular}

Os primers utilizados para a realização da expressão gênica quantitativa dos genes de interesse em brânquias de M. jelskii estão descritos na Tabela 5. O par de primers para qPCR do gene que codifica a proteína ribossomal L10 (PRL10_Pal_F e PRL10_Pal_R) e o par que amplifica a subunidade $\alpha$ da $\mathrm{Na}^{+} / \mathrm{K}^{+}$-ATPase (NaK_Pal_F e NaK_Pal_R) foram desenhados a partir de sequências desse gene em camarões palaemonídeos. Os primers que amplificam a subunidade B da $\mathrm{V}\left(\mathrm{H}^{+}\right)$-ATPase (V_Mbra_F e V_Mbra_R) foram desenhados a partir da sequência desse gene em camarões da espécie Macrobrachium brasiliensis. Todos esses primers citados foram desenhados durante o desenvolvimento do doutorado de Rogério Faleiros, porém apenas a sequência do par de primers para qPCR do gene que codifica a proteína ribossomal L10 (PRL10_Pal_F e PRL10_Pal_R) foi publicado por Faleiros et al., 2017.

Já os primers que amplificam o simportador $\mathrm{Na}^{+} / \mathrm{K}^{+} / 2 \mathrm{Cl}^{-}$(NKCC_Mpot_F e NKCC_Mpot_R) foram desenhados a partir da sequência desse gene em camarões da espécie Macrobrachium potiuna, durante o desenvolvimento do doutorade de Anieli Falaschi (primers não utilizados em publicação até o momento). 
Tabela 5. Sequência dos primers utilizados na qPCR, após validação da eficiência para análises de expressão gênica da PRL10 (PRL10_Pal_F e PRL10_Pal_R), da subunidade $\square \square$ da $\mathrm{Na}^{+} / \mathrm{K}^{+}$-ATPase (NaK_Pal_F e NaK_Pal_R), da subunidade B da V(H+)-ATPase (V_Mbra_F e V_Mbra_R) e do simportador $\mathrm{Na}^{+} / \mathrm{K}^{+} / 2 \mathrm{Cl}^{-}$ (NKCC_Mpot_F e NKCC_Mpot_R), em brânquias Macrobrachium jelskii.

\begin{tabular}{ccc}
\hline Primer & \multicolumn{1}{c}{ Sequência } & $\begin{array}{c}\text { Amplicon } \\
(\mathrm{pb})\end{array}$ \\
\hline PRL10_Pal_F & 5' ATGGGCTGACCAATTCTTACAC 3' & 85 pb \\
PRL10_Pal_R & 5' GTGCTGATAGATTGCAGACAGG 3' & \\
NaK_Pal_F & 5' TGCGAGATTCCCTTCAATTC 3' & \\
NaK_Pal_R & 5' TCTCTCAGGAGCTCCCTTCA 3' & $108 \mathrm{pb}$ \\
& & \\
V_Mbra_F & 5' CATCACTCCTCGACTTGCCC 3' & \\
V_Mbra_R & 5' GCAGCTGATACCTCTCGCAA 3' & $124 \mathrm{pb}$ \\
& & \\
NKCC_Mpot_F & 5' TGACCCAATCCATGCCAACA 3' & $150 \mathrm{pb}$ \\
NKCC_Mpot_R & 5' TCGGTTTCTGCGATTCCCTC 3' & \\
\hline
\end{tabular}

\section{Análise quantitativa da expressão gênica}

Para a análise de expressão por qPCR, utilizamos o termociclador StepOne Plus (Applied Biosystems), localizado no Laboratório de Neuroendocrinologia, Departamento de Fisiologia, FMRP/USP, sob os cuidados dos Profs. Dr. José Antunes Rodrigues e Dra. Lucila L. K. Elias. As reações foram realizadas com primers validados por curva de eficiência e com o reagente PowerUp SYBR ${ }^{\circledR}$ Green PCR Master Mix (ThermoFisher Scientific), de acordo com instruções do fabricante e modificações descritas por Faleiros et al. (2010).

As reações foram preparadas em placas de 96 poços, contendo $50 \%$ de $\mathrm{SYBR}^{\circledR}$ Green Master Mix, primers Forward e Reverse específicos, na concentração final de 0,2 $\mu \mathrm{M}$ cada um, e $2 \mu \mathrm{L}$ do cDNA oriundo de tecido branquial de Dilocarcinus pagei ou Macrobrachium jelskii, diluído 4 vezes em relação ao obtido pela reação de RT-PCR (transcriptase reversa). As condições de termociclagem foram:

1) Desnaturação inicial, $95{ }^{\circ} \mathrm{C} \quad\left(\begin{array}{lll}10 & \mathrm{~min}\end{array}\right)$; 2) Desnaturação, $95{ }^{\circ} \mathrm{C} \quad\left(\begin{array}{ll}15 & \mathrm{~s}\end{array}\right)$; Pareamento/Extensão, $60^{\circ} \mathrm{C}(1 \mathrm{~min}), 40$ ciclos.

Em seguida, foi analisada a curva de dissociação dos produtos formados, para verificar a presença de contaminante, formação de dímeros de primers e/ou amplificação de mais de um amplicon. As condições de termociclagem, nesse caso, foram:

1) $95{ }^{\circ} \mathrm{C}(15 \mathrm{~s})$; 2) $60{ }^{\circ} \mathrm{C}(1 \mathrm{~min})$; 3) Subida lenta $(20 \mathrm{~min})$ para $95{ }^{\circ} \mathrm{C} ; 95^{\circ} \mathrm{C}(15 \mathrm{~s})$. 


\section{Validação dos primers por curva-padrão relativa}

A elaboração da curva-padrão foi feita a partir de diluições seriadas (1: 2, variando de 1: 2 a 1: 64) do pool de todas as amostras de uma mesma espécie, ou seja, um pool para D. pagei e outro para $M$. jelskii, independente do tempo e da salinidade de exposição, incluindo amostras de cDNA das brânquias do grupo controle. Essas diluições foram submetidas à qPCR com cada par de primers a ser validado, além do reagente PowerUp SYBR ${ }^{\circledR}$ Green PCR Master Mix (ThermoFisher Scientific). Após a corrida da qPCR, pode-se aceitar como válidos os primers cuja eficiência da amplificação relacionada à inclinação da reta formada pelos diferentes pontos de diluições seriadas do pool de cada espécie esteja entre 90 e $110 \%$, além do coeficiente de determinação da reta $\left(\mathrm{R}^{2}\right)$ ser $\geq 0.99$.

\section{Quantificação das amostras de interesse}

Com os primers validados, foi realizada a quantificação da expressão dos genes alvos nas amostras por qPCR. A reação para cada amostra foi realizada em triplicata, o que permitiu a detecção de possíveis erros embutidos pelo manuseio, sendo descartado aquele que apresentasse variação maior ou igual a 0,2 ciclo. Controles negativos foram feitos (№

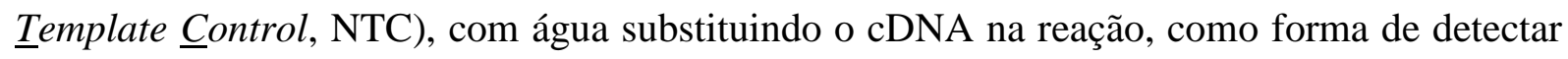
possível contaminação.

Para analisar os dados de expressão gência, utilizamos o método do Ct comparativo. O Ct representa o cycle threshold, ponto onde a curva de amplificação atinge uma linha imaginária estabelecida para cada gene analisado, definida como threshold. $\mathrm{O}$ método do $\mathrm{Ct}$ comparativo envolve a comparação dos valores do $\mathrm{Ct}$ das amostras de interesse com o Ct do grupo calibrador, utilizado como referência de expressão gênica e que no nosso caso é o grupo controle de cada espécie $(\mathrm{t}=0)$. Os valores do $\mathrm{Ct}$ do grupo calibrador e das amostras de interesse são normalizados pelo $\mathrm{Ct}$ de um gene endógeno que tenha expressão constitutiva no tecido analisado, no caso das brânquias, utilizamos o gene que expressa a proteína ribossomal L10 (PRL10). O método do Ct comparativo utiliza a fórmula exponencial $2^{-\Delta \Delta C T}$ (Livak \& Schmittgen, 2001) para cálculo da expressão relativa.

Portanto, quantificamos as expressões relativas dos genes alvos, após normalizar os dados pela expressão correspondente ao gene PRL10, nas mesmas amostras e condições experimentais. Esses resultados foram, ainda, calibrados de acordo a média observada no grupo controle, arbitrariamente convertida ao valor numérico de 1. Logo, os valores finais representam a relação entre os valores obtidos para cada intervalo de tempo em 0 e $25(D$. pagei) ou em 0 e $20 \%$ S (M. jelskii) e o valor do grupo controle $(<0,5 \% \mathrm{~S})$, utilizado como calibrador. 


\subsubsection{Análise de expressão protéica por western blotting}

As proteínas do tecido branquial do caranguejo D. pagei e do camarão $M$. jelskii foram extraídas utilizando o protocolo estabelecido pelo fabricante do reagente Trizol (Invitrogen). Utilizando esse reagente é possível extrair DNA, RNA e proteína de uma mesma amostra. Dessa forma, a partir das brânquias coletadas dos caranguejos ou camarões dos diferentes grupos experimentais, extraímos RNA total, para quantificação da expressão gênica, e proteína, para quantificação da expressão proteica. Após a separação das fases fenolclorofórmio, seguiu-se à purificação das proteínas a partir da fase orgânica de acordo com o protocolo do Trizol. As proteínas foram isoladas, ressuspendidas em SDS 1\%, submetidas a ultrassom por 30 minutos e armazenadas a $-20{ }^{\circ} \mathrm{C}$.

Esse protocolo reduz o número de animais utilizados para geração de dados, além de permitir a obtenção dos resultados de qPCR e western blotting a partir de uma mesma amostra, reduzindo a variabilidade, facilitando a discussão e a relação dos resultados encontrados. A quantificação das proteínas totais se deu utilizando o kit Pierce ${ }^{\mathrm{TM}}$ BCA Protein Assay (ThermoScientific), com leitura em microplacas na absorbância de 562 nm, em leitor de Elisa SpectraMax i3x (Molecular Devices), localizado no Laboratório de Neuroendocrinologia da FMRP-USP, sob responsabilidade dos Profs. Drs. José Antunes Rodrigues e Lucila L. K. Elias.

O homogeneizado proteico foi diluído em $20 \%$ de tampão de amostra Laemmli $5 \mathrm{X}$ concentrado (Laemmli, 1970), sendo a concentração de proteínas totais ajustada para 10-20 $\mu \mathrm{g} / 10-15 \mu \mathrm{L}$. Para aumentar a solubilização, o homogeneizado foi submetido à exposição em ultrassom por 5 minutos e aquecido a $95{ }^{\circ} \mathrm{C}$ durante 5 min, para desnaturação das proteínas. Seguiu-se ao SDS-PAGE, em gel de separação (acrilamida 10\%) e gel de empilhamento (acrilamida 5\%). Para a corrida, foi utilizado o tampão Tris-Glicina (pH 8.3), contendo 0,1\% de SDS, durante aproximadamente $4 \mathrm{~h}$ em voltagem constante de $100 \mathrm{~V}$.

As proteínas do gel foram, então, transferidas para a membrana de PVDF (Hybond ${ }^{\text {TM}}$-P, Amersham Biosciences), em tampão de transferência Towbin sem SDS (Santa Cruz), contendo $10 \%$ de Metanol. A transferência foi realizada durante 1 hora e 30 minutos, em voltagem constante de $100 \mathrm{~V}, \mathrm{a} 4^{\circ} \mathrm{C}$.

Em seguida, a membrana foi corada rapidamente em solução Ponceau 0,2\% para certificação da transferência das proteínas, incluindo o marcador de peso molecular (Page ruler prestrained protein ladder, Thermo Scientific), utilizado como referência. Após descoloração da membrana com água destilada, seguiu-se à incubação com solução de 
bloqueio dos sítios inespecíficos (Bovine Serum Albumin 10\% - Sigma-Aldrich, em Trisbuffered saline with Tween - TBS-T) por 1 h e 30 minutos.

Como a proteína $\mathrm{Na}^{+} \mathrm{K}^{+}$-ATPase possui peso molecular de $110 \mathrm{kDa}$, o simportador $\mathrm{Na}^{+} / \mathrm{K}^{+} / 2 \mathrm{Cl}^{-}$possui peso molecular de $131 \mathrm{kDa}$ e a $\beta$-actina de $42 \mathrm{kDa}$, após o bloqueio a membrana foi recortada ao meio, para incubação da porção superior com o anticorpo primário anti- $\mathrm{Na}^{+} \mathrm{K}^{+}$-ATPase ou anti- $\mathrm{Na}^{+} / \mathrm{K}^{+} / 2 \mathrm{Cl}^{-}$(Hybridoma Banks, cedido pelo Prof. Dr. Francisco Leone, FFCLRP-USP), diluído 150 e 500 vezes, respectivamente. A parte inferior foi incubada com anticorpo primário anti-actina (BD Bioscences), diluído 12000 quando controle endógeno da marcação com anti- $\mathrm{Na}^{+} \mathrm{K}^{+}$-ATPase, ou 2000 vezes quando controle endógeno da marcação com anti- $\mathrm{Na}^{+} / \mathrm{K}^{+} / 2 \mathrm{Cl}^{-}$. Esta diluição foi necessária, pois a revelação do sinal da $\mathrm{Na}^{+} \mathrm{K}^{+}$-ATPase e da $\beta$-actina normalizadora foi diferente da revelação do sinal de $\mathrm{Na}^{+} / \mathrm{K}^{+} / 2 \mathrm{Cl}^{-}$ e seu controle endógeno ( $\beta$-actina). Ambos os anticorpos foram diluídos em TBS-T contendo $5 \%$ de BSA e a incubação com as membranas seguiu-se durante toda a noite ( \pm 16 horas) a $4^{\circ} \mathrm{C}$.

No dia seguinte, as membranas foram lavadas por 5 vezes de 5 minutos com TBS-T, sendo posteriormente incubadas com anticorpo secundário anti-IgG de camundongo conjugado com peroxidade (Sigma-Aldrich), diluído 5000 para membranas incubadas com anti- $\mathrm{Na}^{+} \mathrm{K}^{+}$-ATPase e $\beta$-actina normalizadora, ou 1000 vezes para membranas incubadas com anti- $\mathrm{Na}^{+} / \mathrm{K}^{+} / 2 \mathrm{Cl}^{-}$e respectiva $\beta$-actina, em TBS-T com $5 \%$ de BSA por 1 hora à temperatura ambiente.

Para revelação do sinal da $\mathrm{Na}^{+} \mathrm{K}^{+}$-ATPase e a $\beta$-actina normalizadora, as membranas foram novamente lavadas por 5 vezes de 5 minutos com TBS-T e, em seguida, foram incubadas por 5 minutos com a mistura dos reagentes A e B (1:1) do kit ECL prime western blotting system (GE Healthcare). Após a revelação, as membranas foram fotodocumentadas em aparelho ChemiDoc Imaging Systems (Bio-Rad), localizado no Laboratório de Neuroendocrinologia da FMRP-USP, para captação da quimioluminscência das proteínas reconhecidas pelos anticorpos. A expressão proteica da $\mathrm{Na}^{+} \mathrm{K}^{+}$-ATPase foi quantificada por meio da análise de intensidade relativa das bandas, utilizando o software QuantityOne (BioRad). Os valores da expressão proteica diferencial da $\mathrm{Na}^{+} \mathrm{K}^{+}$-ATPase foram normalizados pelos valores de expressão da proteína $\beta$-actina na mesma amostra.

Para revelação do sinal do $\mathrm{Na}^{+} / \mathrm{K}^{+} / 2 \mathrm{Cl}^{-}$e a $\beta$-actina normalizadora, as membranas foram novamente lavadas por 5 vezes de 5 minutos com TBS-T e, em seguida, foram cobertas com cromógenos da peroxidase (SigmaFAST ${ }^{\mathrm{TM}}$ DAB, 3,3'-Diaminobenzidine substrato de 
peroxidase), permanecendo nesta solução por 5-7 minutos. Após a revelação, a membrana foi mergulhada em água ultrapura para interromper a reação. A membrana foi fotodocumentada e escaneada, para quantificação da expressão proteica por meio da análise de intensidade relativa das bandas, utilizando o software ImageJ (Schneider et al., 2012). Os valores da expressão proteica diferencial do $\mathrm{Na}^{+} / \mathrm{K}^{+} / 2 \mathrm{Cl}^{-}$foram normalizados através da comparação com a expressão da proteína $\beta$-actina (BD Bioscences) na mesma amostra.

\subsubsection{Análises estatísticas}

\section{Efeito da salinidade $X$ tempo de exposição durante o decurso temporal}

Com os dados obtidos para a espécie Dilocarcinus pagei, foram realizadas análises de variância (ANOVA) de dois fatores (Salinidade e Tempo), para avaliar o efeito do tempo de exposição e da salinidade de experimentação, sobre a osmolalidade, concentrações de cloreto e sódio, bem como sobre as expressões gênica e proteica, após averiguar atendimento aos critérios de normalidade de distribuição e igualdade de variâncias. Quando necessário, os dados foram transformados pela função da raiz quadrada. Em seguida, foi feito um teste posthoc de médias múltiplas de Student-Newman-Keuls para localizar as médias estatisticamente diferentes. O programa estatístico utilizado foi o SigmaStat 2.03.

Com os dados obtidos para a espécie Macrobrachium jelskii, realizamos análises de variância (ANOVA) de dois fatores (Salinidade e Tempo) até o tempo de 12 horas, visto que após esse período, os espécimes não sobreviveram em água destilada $(0 \%$ S $)$. Para verificar o efeito do tempo de exposição na salinidade de $20 \%$ S, considerando o decurso temporal de 1 , 3, 5, 12, 24, 72 e 240 horas, realizamos análises de variância (ANOVA) de um único fator (Tempo de exposição). Dessa forma, em M. jelskii, avaliamos o efeito do tempo de exposição e da salinidade de experimentação nos tempos de 0 a 12 horas do decurso temporal, bem como o efeito do tempo de exposição à salinidade de $20 \% \mathrm{~S}$ entre 0 a 240 horas, sobre a osmolalidade, concentrações de cloreto e sódio e expressões gênica e proteica, após averiguar atendimento aos critérios de normalidade de distribuição e igualdade de variâncias. Quando necessário, os dados foram transformados pela função de $\log _{10} \mathrm{X}$. Em seguida, foi feito um teste post-hoc de médias múltiplas de Student-Newman-Keuls para localizar as médias estatisticamente diferentes. O programa estatístico utilizado foi o SigmaStat 2.03.

Em todas as análises foi considerado um nível mínimo de significância de $\mathrm{P}=0,05$. Os dados foram expressos como Média \pm Erro Padrão da Média e plotados em gráfico, utilizando o programa SlideWrite Plus 4.0. 


\section{Incluindo o fator espécie nas análises estatísticas}

Assumindo a ausência de sinal filogenético entre $D$. pagei e $M$. jelskii, dada a grande distância taxonômica entre essas espécies, avaliamos o efeito da exposição às diferentes salinidades, em relação ao tempo de exposição e à espécie submetida ao experimento. Para tal, fizemos análises de variância (ANOVA) de 3 fatores (Salinidade, Tempo e Espécie) com os dados obtidos para osmolalidade, concentrações de cloreto e sódio, bem como para as expressões gênicas relativas. Os critérios de normalidade de distribuição e igualdade de variâncias foram averiguados. Quando necessário, os dados foram transformados usando a função $\log _{10} \mathrm{X}$ ou raiz quadrada de X. O programa estatístico utilizado foi o StatGraphics Centurion.

\section{Correlações entre expressão gênica e proteica}

Fizemos análises de correlação pelo Excel com os valores individuais da expressão gênica versus a expressão proteica de cada espécime de D. pagei e $M$. jelskii, utilizando a função do coeficiente de correlação de Pearson. Montamos gráficos dessas relações no programa SlideWrite Plus 7.0.

\subsubsection{Construcão de fenogramas}

Com a obtenção das sequências parciais dos genes de interesse, construímos fenogramas baseados no alinhamento de sequências similares. Esses grupamentos são construídos baseando-se apenas nas semelhanças entre as bases das sequências de DNA selecionadas de várias espécies de interesse. Esses diagramas não possuem embasamento filogenético, uma vez que não levam em consideração a ancestralidade comum entre os táxons e tampouco foram feitos com genes apropriados para inferência de relações. No entanto, permitem análises interessantes sobre aspectos evolutivos de sequências moleculares.

Para a construção de fenogramas, utilizamos a ferramenta BLAST do NCBI, para alinhamento de sequências similares. Dessa forma, selecionamos a opção nucleotide BLAST, colocamos o número de acesso da sequência de interesse, escolhemos a opção Somewhat similar sequences (blastn) e realizamos o BLAST. Após a busca, surgiram sequências depositadas no banco de dados do NCBI que alinharam de forma significativa com a sequência de interesse. Para a construção dos fenogramas selecionamos no Genbank do NCBI algumas sequências dos mesmos transportadores, obtidas de outras espécies de crustáceos. As sequências alinhadas com as sequências de interesse de Dilocarcinus pagei apresentaram de 69 a 96\% de identidade. As sequências alinhadas com as sequências de interesse de 
Macrobrachium jelskii apresentaram de 70 a $98 \%$ de identidade. A identidade entre sequências ocorre quando há os mesmos resíduos nas mesmas posições em um alinhamento, geralmente expresso em porcentagem (https://www.ncbi.nlm.nih.gov/books/NBK62051/).

Para a construção das árvores de distância (fenogramas) foi o utilizado o Método de Evolução Mínima. Árvore de distância se refere a um dendrograma que agrupa sequências de acordo com suas distâncias da sequência de referência (https://www.ncbi.nlm.nih.gov/Web/Newsltr/V15N1/blastlab.html). Já o Método de Evolução Mínima baseia-se no pressuposto de que a árvore com a menor soma de estimativas de comprimento de ramo é a mais provável de ser verdadeira (Rzhetsky \& Nei, 1993). O comprimento do ramo reflete a fração de substituições de bases em cada sítio pela fração de bases incompatíveis na região alinhada e não está representado nos fenogramas ilustrados. As opções de construção desses fenogramas são dadas na janela de navegação do resultado do BLAST. 
Resultados 


\section{Resultados}

\subsection{O caranguejo de rio, Dilocarcinus pagei}

\subsubsection{Mortalidade dos animais coletados}

Durante o processo de aclimatização laboratorial alguns poucos animais morreram, provavelmente devido à coleta, condições laboratoriais, disputa entre indivíduos e eventos de ecdise (troca do exoesqueleto). Porém, durante a aclimatação, ou seja, durante o acontecimento dos experimentos de incubação dos caranguejos em tempos e salinidades específicos, registramos $12,5 \%$ de mortalidade na condição controle, em água de coleta por 3 dias em habitat semi-terrestre (1 morte de um total de 8 animais). Também registramos 17\% de mortalidade na condição de $0 \%$ S por 24 h ( 1 morte de um total de 6 animais) e $33 \%$ de mortalidade na condição de $25 \%$ S por 3 dias (3 mortes de um total de 9 animais).

\subsubsection{Decurso temporal de osmolalidade, $\left[\mathrm{Cl}^{-}\right]$e $\left[\mathrm{Na}^{+}\right]$durante desafio hiper- ou}

\section{hipo-osmótico}

\section{Osmolalidade}

A ANOVA de dois fatores indicou efeito do tempo, da salinidade e da interação salinidade $\mathrm{X}$ tempo de exposição sobre a osmolalidade da hemolinfa em D. pagei $(\mathrm{P}<0,001)$.

$\mathrm{Na}$ condição controle (água doce, $<0,5 \% \mathrm{~S}, 7 \mathrm{mOsm} \mathrm{kg}^{-1} \mathrm{H}_{2} \mathrm{O}$, tempo 0), a osmolalidade da hemolinfa foi de $313 \pm 22,0 \mathrm{mOsm} \mathrm{kg}^{-1} \mathrm{H}_{2} \mathrm{O}(\mathrm{X} \pm \mathrm{EPM}, \mathrm{N}=7$ ) (Figura 24).

Ao longo do decurso temporal em água destilada $\left(0 \% \mathrm{~S}, 0 \mathrm{mOsm} \mathrm{kg} \mathrm{k}^{-1} \mathrm{H}_{2} \mathrm{O}\right)$, verificouse um aumento na osmolalidade da hemolinfa de D. pagei nos tempos de $3(\mathrm{P}=0,009 \mathrm{SNK})$ a 5 horas de exposição $(\mathrm{P}=0,012 \mathrm{SNK})$ em relação ao tempo $=0$ hora. Posteriormente, $\mathrm{a}$ osmolalidade começou a decair, com queda significativa entre os tempos de 24 a 72 horas (P $=0,012 \mathrm{SNK}$ ) e reestabelecimento do valor inicial (Figura 24).

Já em água salobra (25\%oS, 757 mOsm kg $\left.\mathrm{Hg}_{2} \mathrm{O}\right)$, verificou-se elevação da osmolalidade da hemolinfa após 1 hora de exposição $(\mathrm{P}=0,002 \mathrm{SNK})$, a qual permaneceu até o tempo de 240 horas $(\mathrm{P}<0,001 \mathrm{SNK}$ ). Nesse último tempo, houve aumento significativo da osmolalidade ( $\mathrm{P}<0,001 \mathrm{SNK})$ e a hemolinfa se mostrou aproximadamente isosmótica em relação ao meio externo (789 $\mathrm{mOsm} \mathrm{kg}^{-1} \mathrm{H}_{2} \mathrm{O}$ ) (Figura 24). 


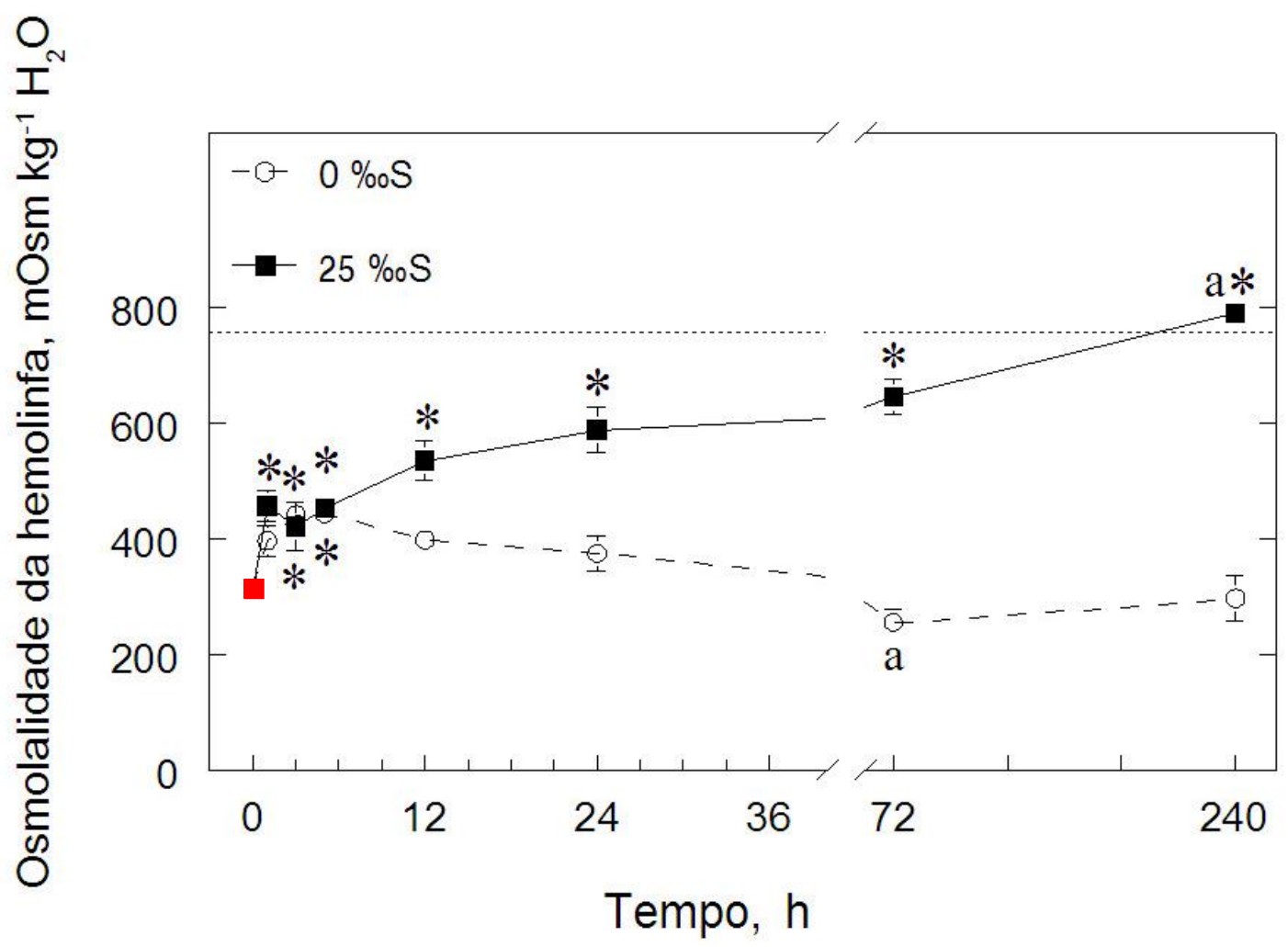

Figura 24. Decurso temporal da osmolalidade $\left(\mathrm{mOsm} \mathrm{kg}^{-1} \mathrm{H}_{2} \mathrm{O}\right)$ da hemolinfa de $D$. pagei, nas salinidades de 0 \%oS (água destilada) e $25 \%$ S (água salobra), ao longo de 10 dias de exposição ( \pm EPM, $5 \leq \mathrm{N} \leq 7$ ). Observase aumento da osmolalidade da hemolinfa entre 3 e 5 horas, em água destilada. Em água salobra a osmolalidade aumenta a partir de 1 hora. *Significativamente diferente em relação ao grupo controle $(<0,5 \%$ S, tempo $=0$,

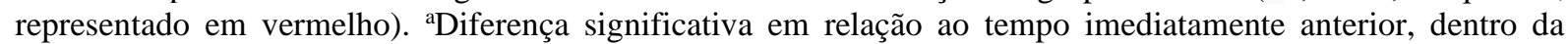
mesma salinidade. A linha pontilhada indica a osmolalidade da água a $25 \% \mathrm{~S}\left(757 \mathrm{mOsm} \mathrm{kg}^{-1} \mathrm{H}_{2} \mathrm{O}\right)$.

A osmolalidade da hemolinfa (em mOsm $\mathrm{kg}^{-1} \mathrm{H}_{2} \mathrm{O}$ ) nos diferentes tempos experimentais em água destilada $(0 \% \mathrm{~S})$ foi de: $397 \pm 26,2 \mathrm{em} 1$ hora $(\mathrm{N}=7), 441 \pm 7,4 \mathrm{em} 3$ horas $(\mathrm{N}=5), 443 \pm 18,6$ em 5 horas $(\mathrm{N}=5), 398 \pm 11,1 \mathrm{em} 12$ horas $(\mathrm{N}=5), 374 \pm 30,7 \mathrm{em}$ 24 horas $(\mathrm{N}=5), 255 \pm 23,7$ em 72 horas $(\mathrm{N}=7)$ e $297 \pm 38,4$ em 240 horas $(\mathrm{N}=5)$.

Em água salobra $(25 \% \mathrm{~S})$, a osmolalidade da hemolinfa (mOsm kg-1 $\left.\mathrm{H}_{2} \mathrm{O}\right)$ nos diferentes tempos experimentais foi de: $457 \pm 26,3$ em 1 hora $(\mathrm{N}=5), 421 \pm 42,6 \mathrm{em} 3$ horas $(\mathrm{N}=5), 453 \pm 22,7 \mathrm{em} 5$ horas $(\mathrm{N}=5), 535 \pm 35,2 \mathrm{em} 12$ horas $(\mathrm{N}=5), 588 \pm 40,2 \mathrm{em} 24$ horas $(\mathrm{N}=5), 644 \pm 30,4 \mathrm{em} 72$ horas $(\mathrm{N}=6)$ e $789 \pm 13,3$ em 240 horas $(\mathrm{N}=5)$.

\section{$\left[\mathrm{Cl}^{-}\right]$}

A ANOVA de dois fatores indicou efeito do tempo, da salinidade e da interação salinidade $\mathrm{X}$ tempo de exposição sobre a $\left[\mathrm{Cl}^{-}\right]$da hemolinfa em D. pagei $(\mathrm{P}<0,001)$.

$\mathrm{Na}$ condição controle (água doce, $<0,5 \% \mathrm{~S}, 2,1 \mathrm{mmol} \mathrm{L}^{-1}$, tempo $=0$ hora), a $\left[\mathrm{Cl}^{-}\right] \mathrm{da}$ hemolinfa foi de $157 \pm 13,4 \mathrm{mmol} \mathrm{L}^{-1}(\mathrm{X} \pm \mathrm{EPM}, \mathrm{N}=7)$ (Figura 25). 
Ao longo do decurso temporal em água destilada $\left(0 \% \mathrm{~S}, 0 \mathrm{mmol} \mathrm{L}{ }^{-1}\right)$, não foi observada mudança significativa na $\left[\mathrm{Cl}^{-}\right]$da hemolinfa de D. pagei em relação ao tempo $=0$ hora. Porém é observada uma tendência de aumento no tempo de 3 horas de exposição, com diferenças significativas em relação aos tempos mais tardios de $72(\mathrm{P}<0,001 \mathrm{SNK})$ e 240 horas $(\mathrm{P}=$ 0,031 SNK) (Figura 25).

Já em água salobra $\left(25 \% \mathrm{~S}, 395 \mathrm{mmol} \mathrm{L}{ }^{-1}\right)$, houve elevação da $\left[\mathrm{Cl}^{-}\right]$da hemolinfa a partir de 1 hora de exposição $(\mathrm{P}=0,015 \mathrm{SNK})$, a qual permaneceu até o tempo de 240 horas $(\mathrm{P}<0,001 \mathrm{SNK})$, com aumentos significativos nos tempos de $72(\mathrm{P}=0,007 \mathrm{SNK})$ e 240 horas $(\mathrm{P}<0,001 \mathrm{SNK})$. Nesse último tempo, a hemolinfa se mostrou aproximadamente isoclorêmica em relação ao meio externo (400 $\left.\mathrm{mmol} \mathrm{L}^{-1}\right)$ (Figura 25).

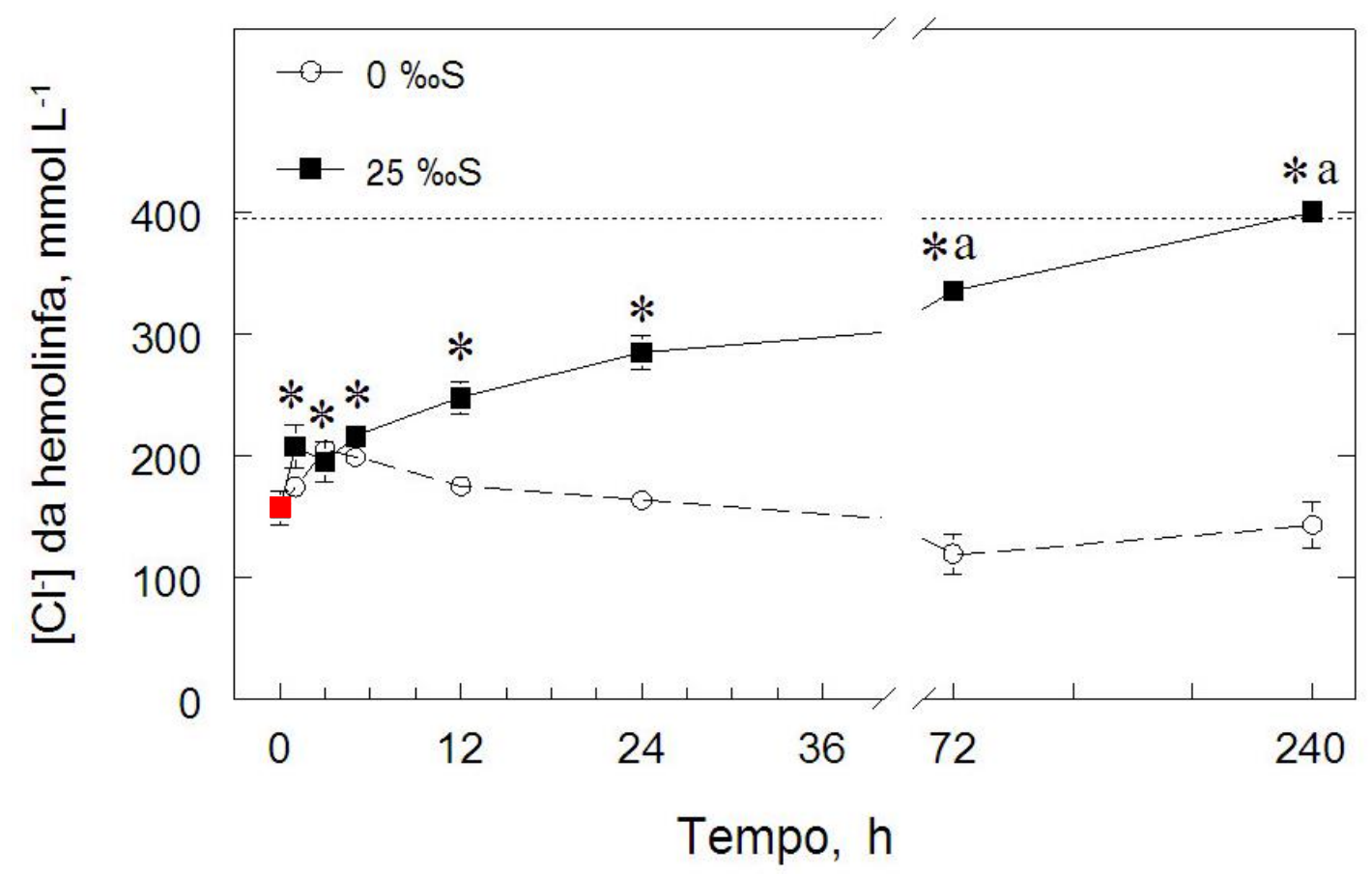

Figura 25. Decurso temporal da $\left[\mathrm{Cl}^{-}\right]\left(\mathrm{mmol} \mathrm{L}^{-1}\right)$ da hemolinfa de $D$. pagei, nas salinidades de $0 \% \mathrm{o}$ (água destilada) e $25 \% \mathrm{~S}$ (água salobra), ao longo de 10 dias de exposição $(\mathrm{X} \pm \mathrm{EPM}, 5 \leq \mathrm{N} \leq 7)$. Não houve variação na $\left[\mathrm{Cl}^{-}\right]$ao longo do decurso temporal, em relação ao tempo $=0$ hora. Em água salobra, a $\left[\mathrm{Cl}^{-}\right]$aumenta significativamente a partir de 1 hora. *Significativamente diferente em relação ao grupo controle $(<0,5 \% \mathrm{~S}$,

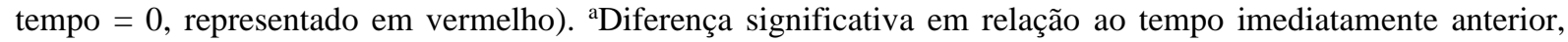
dentro da mesma salinidade. A linha pontilhada indica a $\left[\mathrm{Cl}^{-}\right]$na água a $25 \% \mathrm{~S}\left(395 \mathrm{mmol} \mathrm{L}^{-1}\right)$.

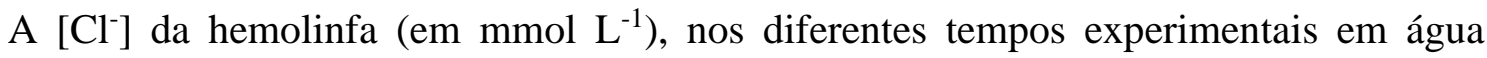
destilada $(0 \% \mathrm{~S})$, foi de: $174 \pm 8,8 \mathrm{em} 1$ hora $(\mathrm{N}=7), 204 \pm 6,0$ em 3 horas $(\mathrm{N}=5), 199 \pm 9,2$ em 5 horas $(\mathrm{N}=5), 175 \pm 4,0$ em 12 horas $(\mathrm{N}=5), 163 \pm 4,6$ em 24 horas $(\mathrm{N}=5), 119 \pm 16,4$ em 72 horas $(\mathrm{N}=7)$ e $143 \pm 19,5$ em 240 horas $(\mathrm{N}=5)$. 
Em água salobra $(25 \% \mathrm{~S})$, a $\left[\mathrm{Cl}^{-}\right]$da hemolinfa $\left(\mathrm{mmol} \mathrm{L}^{-1}\right)$, nos diferentes tempos experimentais foi de: $207 \pm 17,4$ em 1 hora $(\mathrm{N}=5), 195 \pm 16,2$ em 3 horas $(\mathrm{N}=5), 216 \pm$ 11,3 em 5 horas $(\mathrm{N}=5), 247 \pm 13,6 \mathrm{em} 12$ horas $(\mathrm{N}=5), 284 \pm 14,3$ em 24 horas $(\mathrm{N}=5)$, $335 \pm 10,1$ em 72 horas $(\mathrm{N}=6)$ e $400 \pm 7,8$ em 240 horas $(\mathrm{N}=5)$.

\section{$\left[\mathrm{Na}^{+}\right]$}

A ANOVA de dois fatores indicou efeito da salinidade $(\mathrm{P}<0,001)$ e da interação salinidade $\mathrm{X}$ tempo de exposição $(\mathrm{P}<0,001)$. Porém não houve efeito do tempo de exposição $(\mathrm{P}=0,113)$ sobre a $\left[\mathrm{Na}^{+}\right]$da hemolinfa em $D$. pagei.

$\mathrm{Na}$ condição controle (água doce, $<0,5 \% \mathrm{~S}, 6,8 \mathrm{mmol} \mathrm{L}{ }^{-1}$, tempo $=0$ hora), a $\left[\mathrm{Na}^{+}\right] \mathrm{da}$ hemolinfa foi de $143 \pm 19,6 \mathrm{mmol} \mathrm{L}^{-1}(\mathrm{X} \pm \mathrm{EPM}, \mathrm{N}=7$ ) (Figura 26).

Ao longo do decurso temporal em água destilada $(0 \% \mathrm{~S})$, houve uma diminuição na $\left[\mathrm{Na}^{+}\right]$da hemolinfa de $D$. pagei entre os tempos de $24(\mathrm{P}=0,010 \mathrm{SNK})$ a 240 horas de exposição ( $\mathrm{P}=0,024$ SNK) (Figura 26).

Em água salobra $\left(25 \% \mathrm{~S}, 304 \mathrm{mmol} \mathrm{L}{ }^{-1}\right)$, houve elevação da $\left[\mathrm{Na}^{+}\right]$da hemolinfa após 24 horas de exposição $(\mathrm{P}=0,002 \mathrm{SNK})$, que se manteve até 240 horas $(\mathrm{P}<0,001 \mathrm{SNK})$. A partir de 72 horas, a hemolinfa se mostrou isonatrêmica em relação ao meio externo (299 mmol L'-1) (Figura 26).

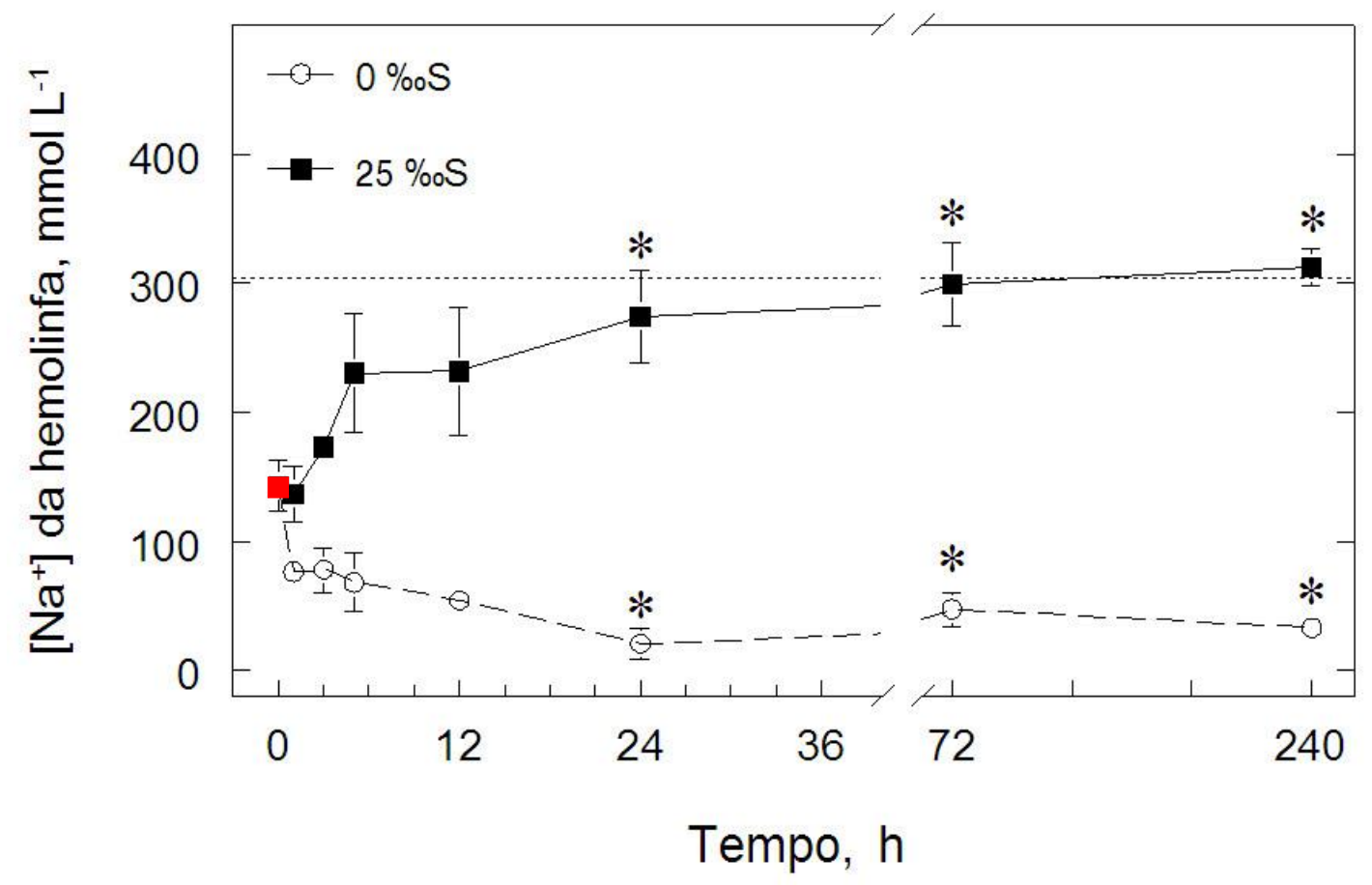

Figura 26. Decurso temporal da $\left[\mathrm{Na}^{+}\right]\left(\mathrm{mmol} \mathrm{L}^{-1}\right)$ da hemolinfa de $D$. pagei, nas salinidades de $0 \% \mathrm{~S}$ (água destilada) e $25 \% \mathrm{~S}$ (água salobra), ao longo de 10 dias de exposição ( $\pm \mathrm{EPM}, 5 \leq \mathrm{N} \leq 7$ ). Observa-se que a $\left[\mathrm{Na}^{+}\right]$diminuiu entre os tempos de 24 a 240 horas, em água destilada. Em água salobra, a $\left[\mathrm{Na}^{+}\right]$aumenta a partir de 24 horas. *Significativamente diferente em relação ao grupo controle $(<0,5 \%$ S, tempo $=0$, representado em 
vermelho). ${ }^{a}$ Diferença significativa em relação ao tempo imediatamente anterior, dentro da mesma salinidade. A linha pontilhada indica a $\left[\mathrm{Na}^{+}\right]$na água a $25 \% \mathrm{~S}(304 \mathrm{mmol} \mathrm{L}-1)$.

A $\left[\mathrm{Na}^{+}\right]$da hemolinfa $\left(\mathrm{em} \mathrm{mmol} \mathrm{L} \mathrm{L}^{-1}\right)$ nos diferentes tempos experimentais em água destilada $(0 \% \mathrm{~S})$ foi de: $77 \pm 10,7 \mathrm{em} 1$ hora $(\mathrm{N}=7), 78 \pm 17,3 \mathrm{em} 3$ horas $(\mathrm{N}=5), 68 \pm 22,8$ em 5 horas $(\mathrm{N}=5), 54 \pm 11,1$ em 12 horas $(\mathrm{N}=5), 21 \pm 12,1 \mathrm{em} 24$ horas $(\mathrm{N}=5), 48 \pm 13,1$ em 72 horas $(\mathrm{N}=7)$ e $31 \pm 10,9$ em 240 horas $(\mathrm{N}=5)$.

Em água salgada $(25 \% \mathrm{~S}), \mathrm{a}\left[\mathrm{Na}^{+}\right]\left(\mathrm{mmol} \mathrm{L}^{-1}\right)$ nos diferentes tempos experimentais foi de: $137 \pm 21,4$ em 1 hora $(\mathrm{N}=5), 173 \pm 2,2$ em 3 horas $(\mathrm{N}=5), 230 \pm 45,7$ em 5 horas $(\mathrm{N}=$ 5), $232 \pm 49,2 \mathrm{em} 12$ horas $(\mathrm{N}=5), 274 \pm 75,7 \mathrm{em} 24$ horas $(\mathrm{N}=5), 299 \pm 32,1 \mathrm{em} 72$ horas $(\mathrm{N}=6)$ e $312 \pm 14,5$ em 240 horas $(\mathrm{N}=5)$.

\subsubsection{Análises das expressões dos ionotransportadores por qPCR em brânquias de}

\section{$\underline{\text { D. pagei }}$}

\section{Expressão gênica da subunidade B da $\mathrm{V}\left(\mathrm{H}^{+}\right)$-ATPase}

A ANOVA de dois fatores indicou efeito do tempo de exposição $(\mathrm{P}<0,001)$, da salinidade $(\mathrm{P}<0,001)$ e da interação salinidade $\mathrm{X}$ tempo de exposição $(\mathrm{P}=0,005)$ sobre a expressão de RNA mensageiro da subunidade B da $\mathrm{V}\left(\mathrm{H}^{+}\right)$-ATPase em D. pagei. Para a análise estatística, os valores de expressão foram transformados pela função raiz quadrada de X.

Em água destilada $(0 \% \mathrm{~S})$, em comparação à condição controle (água doce, $<0,5 \% \mathrm{~S}$, tempo $=0$ hora, $\mathrm{N}=7$ ), não houve alteração da expressão da expressão da $\mathrm{V}\left(\mathrm{H}^{+}\right)$-ATPase ao longo do decurso temporal, embora haja uma tendência de aumento entre 5 e 12 horas (Figura 27).

Em água salgada $(25 \% \mathrm{~S})$, houve diminuição na expressão da $\mathrm{V}\left(\mathrm{H}^{+}\right)$-ATPase de $3(\mathrm{P}=$ 0,010 SNK) a 240 horas ( $<$ < 0,001 SNK) de exposição em relação ao grupo controle (água doce, $<0,5 \% \mathrm{~S}$, tempo $=0$ hora, $\mathrm{N}=7)$, com exceção do tempo de 5 horas $(\mathrm{P}=0,142 \mathrm{SNK})$ (Figura 27). 


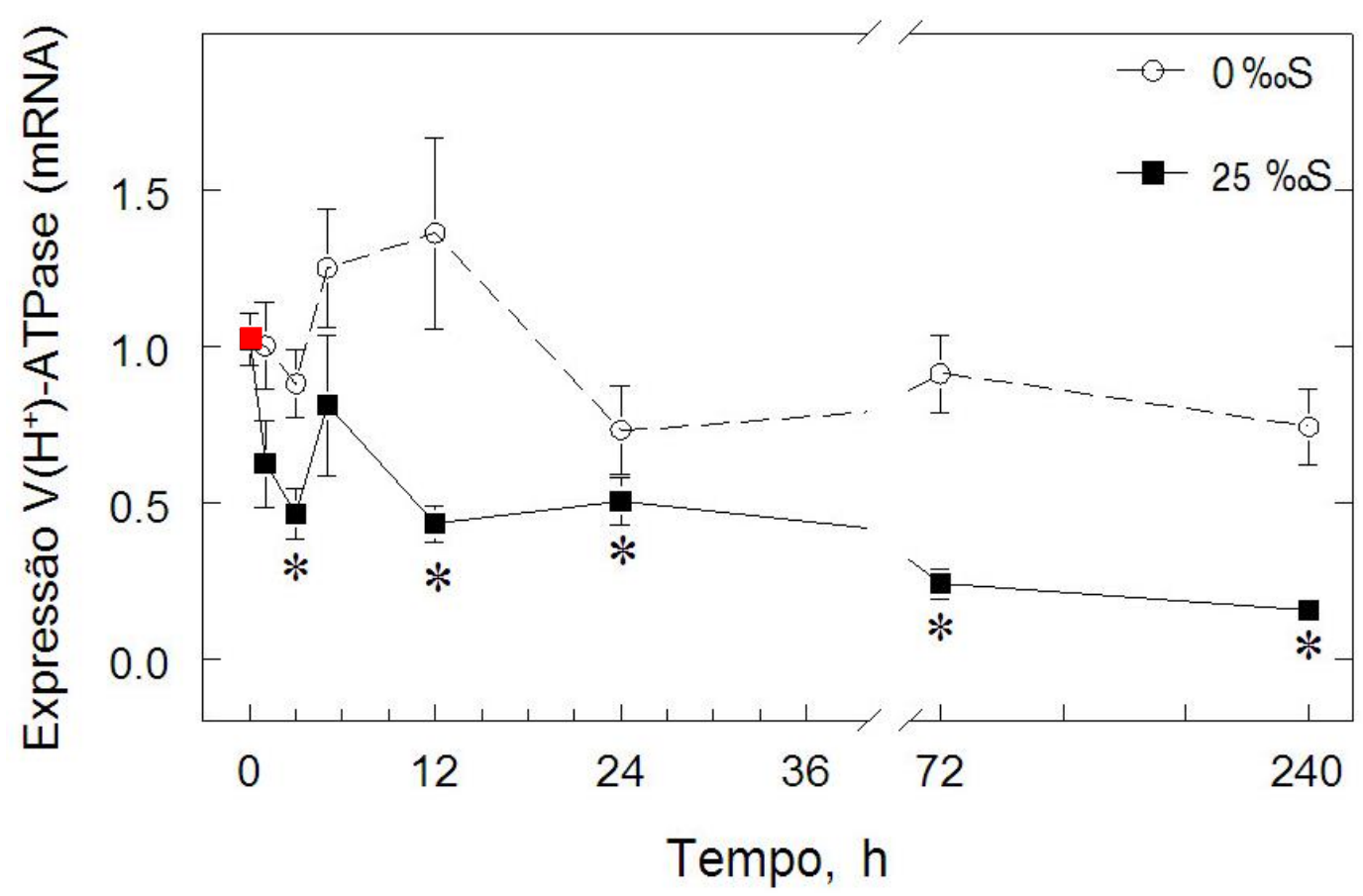

Figura 27. Decurso temporal do efeito da aclimatação às salinidades de 0 (água destilada) ou $25 \%$ S sobre a expressão quantitativa de mRNA da subunidade $\mathrm{B}$ da $\mathrm{V}\left(\mathrm{H}^{+}\right)$-ATPase branquial de D. pagei $(\mathrm{X} \pm \mathrm{EPM}, 4 \leq \mathrm{N} \leq$ 7). A análise foi realizada por PCR em Tempo Real e a expressão da $\mathrm{V}\left(\mathrm{H}^{+}\right)$-ATPase foi normalizada pela expressão do gene PRL10 (constitutiva), em cada amostra. Os valores finais representam a taxa de expressão relativa do gene em cada intervalo de tempo a 0 ou $25 \% \mathrm{~S}$, em relação ao grupo controle $(<0,5 \% \mathrm{~S}$, tempo $=0$, representado em vermelho), utilizado como calibrador. *Significativamente diferente em relação ao grupo controle.

\section{Expressão gênica da subunidade $\alpha$ da $\mathrm{Na}^{+} / \mathrm{K}^{+}$-ATPase}

A ANOVA de dois fatores indicou efeito do tempo de exposição $(\mathrm{P}<0,001)$ e da salinidade $(\mathrm{P}<0,001)$ sobre a expressão de RNA mensageiro da subunidade $\alpha$ da $\mathrm{Na}^{+} / \mathrm{K}^{+}-$ ATPase em D. pagei. Porém, não indicou efeito da interação da salinidade $\mathrm{X}$ tempo de exposição $(\mathrm{P}=0,062)$. Para a análise estatística, os valores de expressão foram transformados pela função raiz quadrada de $X$.

Em água destilada $(0 \% \mathrm{O})$ foi detectada diminuição significativa na expressão da $\mathrm{Na}^{+} / \mathrm{K}^{+}$-ATPase a partir de 24 horas de exposição $(\mathrm{P}=0,024 \mathrm{SNK})$ em relação ao grupo controle (água doce, $<0,5 \% \mathrm{~S}$, tempo $=0$ hora, $\mathrm{N}=7$ ), que se manteve até 240 horas $(\mathrm{P}=$ 0,006 SNK) (Figura 28).

Em água salobra a $25 \% \mathrm{~S}$, houve diminuição na expressão da $\mathrm{Na}^{+} / \mathrm{K}^{+}$-ATPase já a partir de 1 hora de exposição $(\mathrm{P}=0,027 \mathrm{SNK})$, a qual se manteve até o tempo final de 240 horas $(\mathrm{P}$ $<0,001 \mathrm{SNK}$ ), em relação à condição controle (água doce, $<0,5 \% \mathrm{~S}$, tempo $=0$ hora, $\mathrm{N}=7$ ) (Figura 28). 


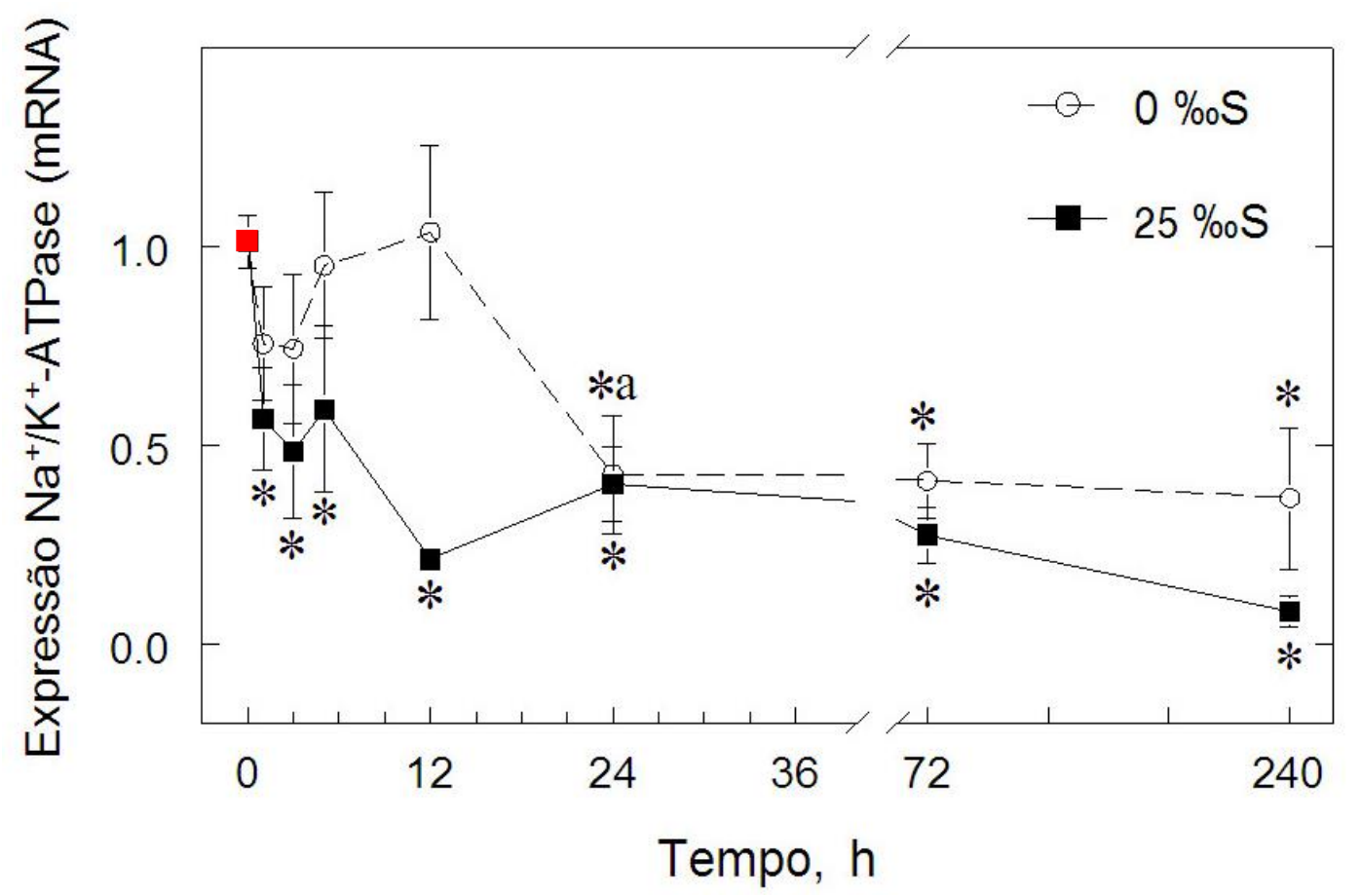

Figura 28. Decurso temporal do efeito da aclimatação às salinidades de 0 (água destilada) ou $25 \%$ S sobre a expressão quantitativa de mRNA da subunidade $\alpha$ da $\mathrm{Na}^{+} / \mathrm{K}^{+}$-ATPase branquial de D. pagei $(\mathrm{X} \pm \mathrm{EPM}, 4 \leq \mathrm{N} \leq$ 7). A análise foi realizada por PCR em Tempo Real e a expressão da $\mathrm{Na}^{+} / \mathrm{K}^{+}$-ATPase foi normalizada pela expressão do gene PRL10 (constitutiva), em cada amostra. Os valores finais representam a taxa de expressão relativa do gene em cada intervalo de tempo a 0 ou $25 \% \mathrm{~S}$, em relação ao grupo controle $(<0,5 \% \mathrm{~S}$, tempo $=0$, representado em vermelho), utilizado como calibrador. *Significativamente diferente em relação ao grupo controle. ${ }^{a}$ Diferença significativa em relação ao tempo imediatamente anterior, dentro da mesma salinidade.

\section{Expressão gênica do simportador $\mathrm{Na}^{+} / \mathrm{K}^{+} / 2 \mathrm{Cl}^{-}$}

A ANOVA de dois fatores indicou efeito do tempo de exposição $(\mathrm{P}=0,012)$, da salinidade $(\mathrm{P}<0,001)$ e da interação da salinidade $\mathrm{X}$ tempo de exposição $(\mathrm{P}=0,038)$ sobre a expressão de RNA mensageiro do simportador $\mathrm{Na}^{+} / \mathrm{K}^{+} / 2 \mathrm{Cl}^{-}$em D. pagei. Para a análise estatística, os valores de expressão foram transformados pela função raiz quadrada de X.

Em água destilada $(0 \% \mathrm{~S})$ não foram detectadas mudanças significativas na expressão do simportador $\mathrm{Na}^{+} / \mathrm{K}^{+} / 2 \mathrm{Cl}^{-}$ao longo do decurso temporal em relação ao grupo controle (água doce, $<0,5 \% \mathrm{~S}$, tempo $=0$ hora, $\mathrm{N}=7$ ), embora haja uma tendência de aumento no tempo de 72 horas (Figura 29).

Em água salobra a $25 \% \mathrm{~S}$, houve diminuição na expressão do simportador $\mathrm{Na}^{+} / \mathrm{K}^{+} / 2 \mathrm{Cl}^{-}$ no tempo mais tardio de exposição do decurso temporal, 240 horas (P $<0,001$ SNK), em relação à condição controle (água doce, $<0,5 \%$ S , tempo $=0$ hora, $\mathrm{N}=7$ ) (Figura 29). 


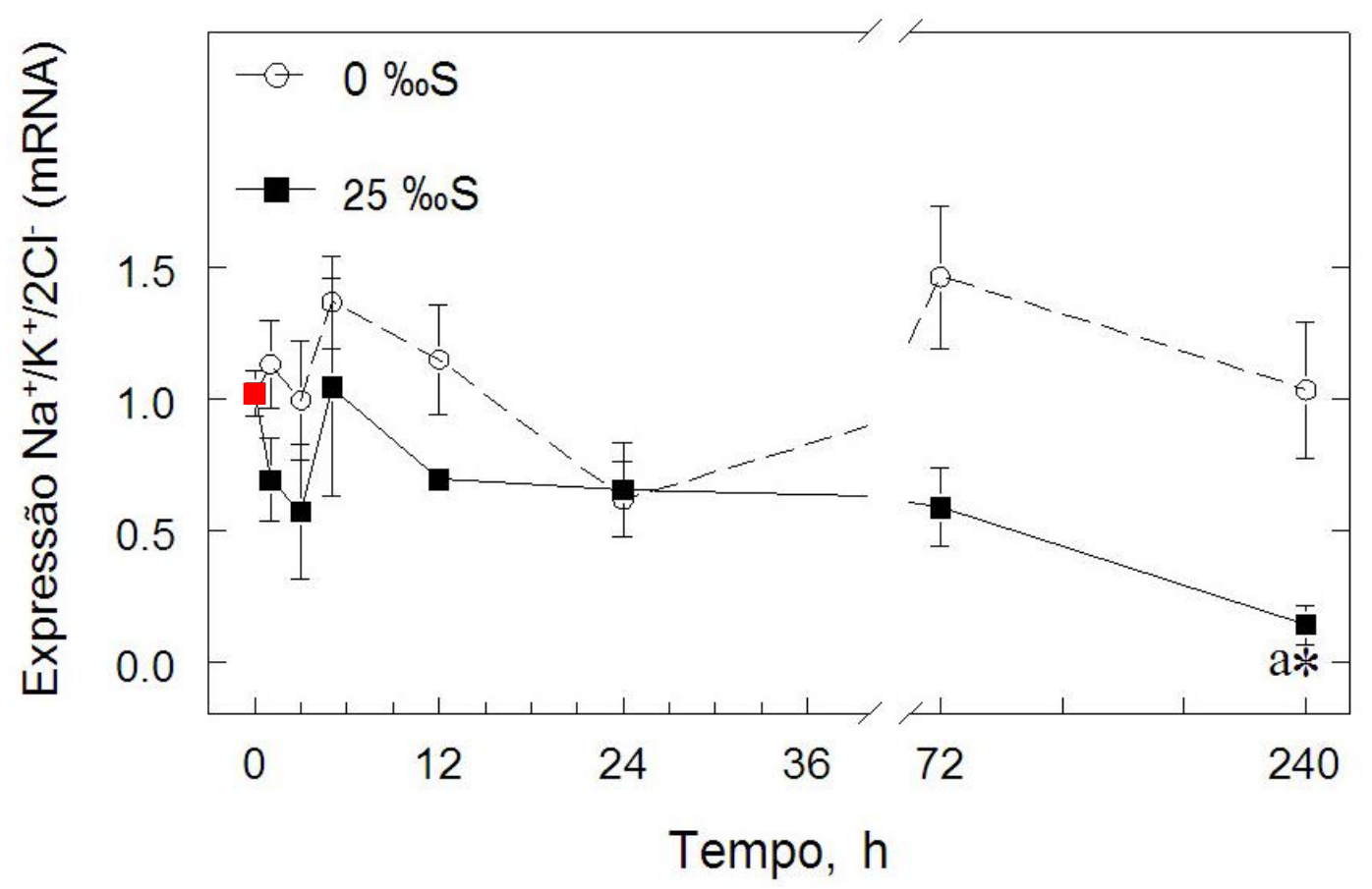

Figura 29. Decurso temporal do efeito da aclimatação às salinidades de 0 (água destilada) ou $25 \% \mathrm{~S}$ sobre a expressão quantitativa de mRNA do simportador $\mathrm{Na}^{+} / \mathrm{K}^{+} / 2 \mathrm{Cl}^{-}$branquial de D. pagei $(\mathrm{X} \pm \mathrm{EPM}, 4 \leq \mathrm{N} \leq 7)$. A análise foi realizada por PCR em Tempo Real e a expressão do simportador $\mathrm{Na}^{+} / \mathrm{K}^{+} / 2 \mathrm{Cl}^{-}$foi normalizada pela expressão do gene PRL10 (constitutiva), em cada amostra. Os valores finais representam a taxa de expressão relativa do gene em cada intervalo de tempo a 0 ou $25 \% \mathrm{~S}$, em relação ao grupo controle $(<0,5 \% \mathrm{~S}$, tempo $=0$, representado em vermelho), utilizado como calibrador. *Significativamente diferente em relação ao grupo controle. ${ }^{a}$ Diferença significativa em relação ao tempo imediatamente anterior, dentro da mesma salinidade.

\subsubsection{Expressão proteica do ionotransportador $\mathrm{Na}^{+} / \mathrm{K}^{+}$-ATPase em brânquias de $D$.} pagei

A ANOVA de dois fatores não indicou efeito do tempo de exposição $(P=0,891)$ nem da salinidade $(\mathrm{P}=0,451)$, tampouco do efeito da interação da salinidade $\mathrm{X}$ tempo de exposição $(\mathrm{P}=0,227)$ sobre a expressão proteica da $\mathrm{Na}^{+} / \mathrm{K}^{+}$-ATPase em brânquias de $D$. pagei (Figura 30).

Embora a Figura 30 ilustre que a expressão ao longo do decurso temporal em água destilada $(0 \% \mathrm{~S})$ pareça oposta à expressão ao longo do tempo em água salobra $(25 \% \mathrm{~S})$, não foram detectadas quaisquer mudanças significativas na expressão proteica de $\mathrm{Na}^{+} / \mathrm{K}^{+}$-ATPase nos grupos experimentais, em relação ao grupo controle (água doce, $<0,5 \% \mathrm{~S}$, tempo $=0$ hora, $\mathrm{N}=4)$. 


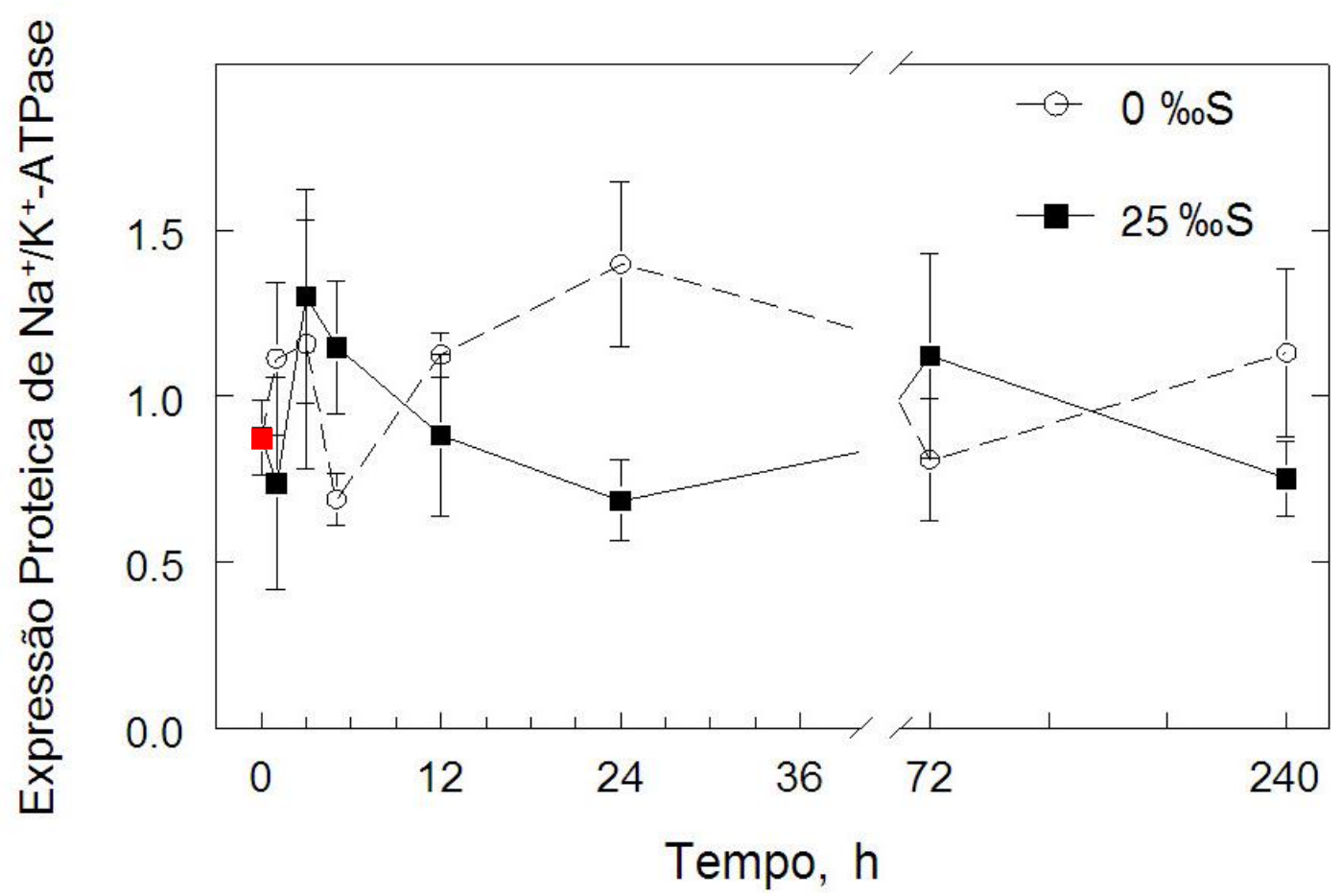

Figura 30. Decurso temporal do efeito da aclimatação às salinidades de 0 (água destilada) ou $25 \%$ S sobre a expressão proteica de $\mathrm{Na}^{+} / \mathrm{K}^{+}$-ATPase branquial de $D$. pagei $(\mathrm{X} \pm \mathrm{EPM}, 3 \leq \mathrm{N} \leq 6)$. A análise foi realizada por western blotting e a expressão da proteína de interesse foi normalizada pela expressão proteica da $\beta$-actina (constitutiva), em cada amostra. Os valores finais representam a taxa de expressão proteica em cada intervalo de tempo a 0 ou $25 \% \mathrm{~S}$, em relação ao grupo controle $(<0,5 \% \mathrm{~S}$, tempo $=0$, representado em vermelho $)$.

\subsubsection{Correlação entre as expressões gênica e proteica do ionotransportador}

\section{$\underline{\mathrm{Na}^{+} / \mathrm{K}^{+} \text {-ATPase em brânquias de } D \text {. pagei }}$}

Apesar da ausência de alteração na expressão proteica da $\mathrm{Na}^{+} / \mathrm{K}^{+}$-ATPase em $D$. pagei em qualquer condição experimental (decurso temporal em água destilada ou salobra), analisamos, por meio do coeficiente de correlação de Pearson, as relações entre a expressão gênica e proteica nas diferentes condições experimentais.

Como mostra a Figura 31, não houve nenhuma correlação forte $(\mathrm{R}>0,7$ ou $\mathrm{R}<-0,7)$ entre as expressões gênica e proteica da $\mathrm{Na}^{+} / \mathrm{K}^{+}$-ATPase em $D$. pagei, em água destilada ( 0 $\% \mathrm{~S}, \mathrm{R}=-0,074)$ ou em água salobra $(25 \% \mathrm{~S}, \mathrm{R}=0,120)$. 


\section{$\mathrm{Na}^{+} / \mathrm{K}^{+}$-ATPase}
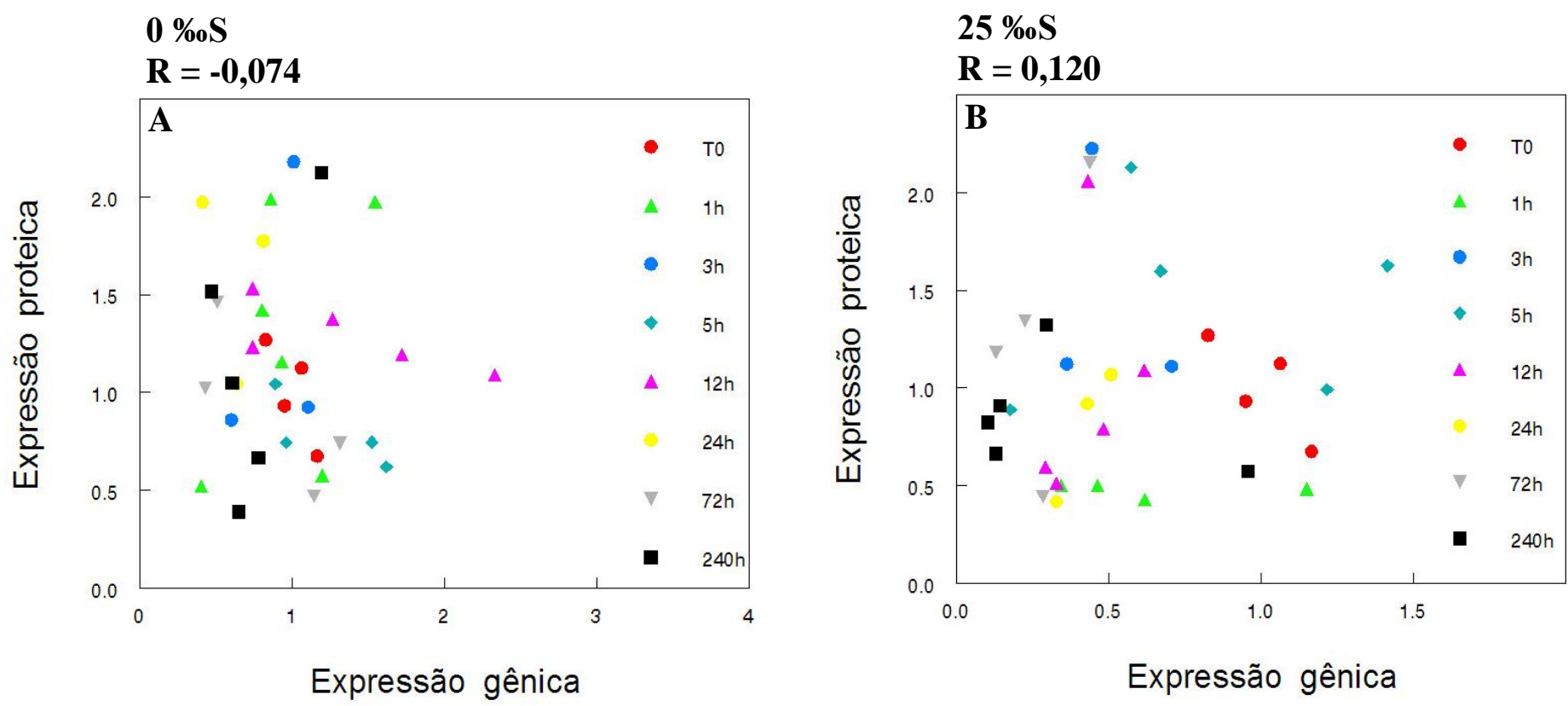

Figura 31. Correlações de Pearson entre as expressões gênica e proteica de $\mathrm{Na}^{+} / \mathrm{K}^{+}$-ATPase em brânquias do caranguejo de água doce Dilocarcinus pagei. A) Dados das expressões em brânquias de caranguejos submetidos ao decurso temporal em água destilada $(0 \% \mathrm{~S})(\mathrm{R}=-0,074)$. B) Dados das expressões em brânquias de caranguejos submetidos ao decurso temporal na salinidade de $25 \% \mathrm{~S}(\mathrm{R}=0,120)$. Os valores de $\mathrm{R}$ correspondem ao coeficiente de correlação de Pearson e não são significativos.

\subsection{Macrobrachium jelskii}

\subsubsection{Mortalidade dos animais coletados}

Durante o processo de aclimatização laboratorial poucos animais morreram, provavelmente devido à coleta, condições laboratoriais, disputa entre alguns espécimes e eventos de ecdise (troca do exoesqueleto). Porém, durante a aclimatação, ou seja, durante o acontecimento dos experimentos de incubação dos camarões em tempos e salinidades específicos, registramos $20 \%$ de mortalidade na condição de $20 \%$ S por 24 horas (4 mortes de um total de 20 animais) e 35,3\% de mortalidade na condição de $20 \%$ S por 3 dias (6 mortes em um total de 17 animais). Em água destilada (0\% \% nenhum camarão sobreviveu até o tempo de 24 horas e, dessa forma, o decurso temporal nessa salinidade, para essa espécie, foi analisado até o tempo de 12 horas. 


\subsubsection{Determinacão do desafio hiperosmótico a partir do limite letal superior de} salinidade (LSS $\left.\mathbf{L S}_{\mathbf{5}}\right)$

Visando determinar o desafio hiperosmótico que representasse $80 \%$ do limite letal superior de salinidade $\left(\mathrm{LSS}_{50}\right)$ para $M$. jelskii, fizemos curvas de porcentagem de sobrevivência em diferentes salinidades.

A sobrevivência de $M$. jelskii observada durante exposição por 120 h foi de $91,7 \%$ na salinidade de $20 \%$ S, 72,7\% em $24 \%$ S, 69,2\% em $26 \%$ S e 8,3\% em $28 \%$ S. Não houve mortalidade em espécies mantidas em água do local de coleta $(<0,5 \% \mathrm{~S})$.

$\mathrm{O}$ valor calculado a partir da análise Probit correspondente à $\operatorname{LSS}_{50}$ foi de $25,4 \%$. A partir desse valor, estabeleceu-se a salinidade hiper-osmótica experimental de 20 \%o (Figura 32), que corresponde a $80 \%$ da $\mathrm{LSS}_{50}$ para a espécie. A escolha pelo valor de $80 \%$ da $\mathrm{LSS}_{50}$ é a geralmente utilizada por nosso grupo de pesquisa, por representar um desafio hiperosmótico em uma salinidade subletal.

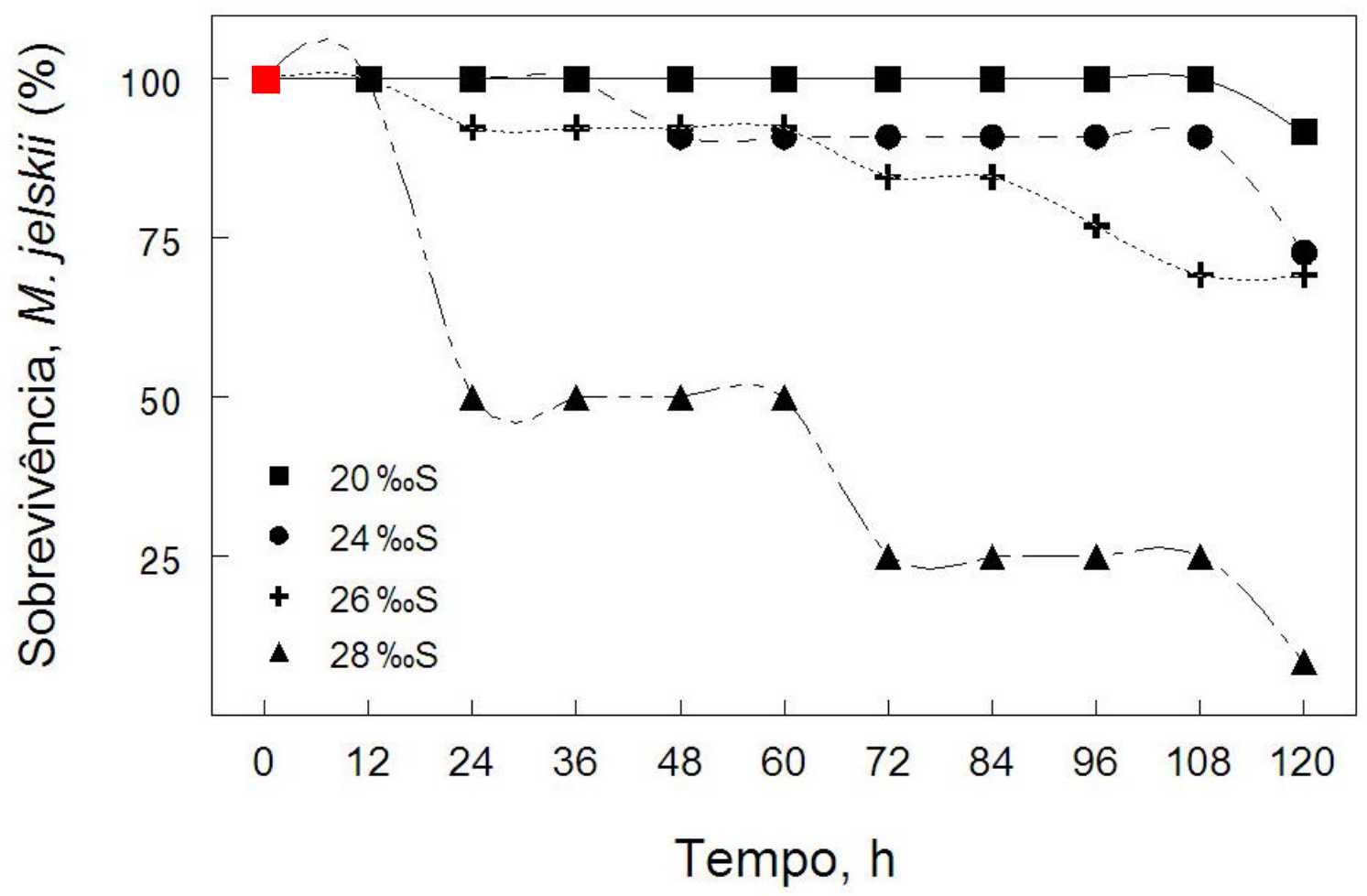

Figura 32. Curvas de sobrevivência $(\%)$ de $M$. jelskii, quando espécimes $(11<\mathrm{N}<13)$ foram submetidos às salinidades de 20,24, 26 e $28 \% \mathrm{~S}$, durante 120 horas. O tempo $=0$ hora, respresentado em vermelho, corresponde à condição controle em água doce $(0,5 \% \mathrm{~S}, \mathrm{~N}=12)$. 


\subsubsection{Decurso temporal de osmolalidade, $\left[\mathrm{Cl}^{-}\right]$e $\left[\mathrm{Na}^{+}\right]$da hemolinfa}

\section{Osmolalidade}

A ANOVA de dois fatores para decurso temporal de até 12 horas indicou efeito da salinidade e da interação salinidade $\mathrm{X}$ tempo de exposição $(\mathrm{P}<0,001)$. Porém, o efeito do tempo de exposição à salinidade $(\mathrm{P}=0,055)$ sobre a osmolalidade da hemolinfa em M. jelskii foi apenas marginal.

Na condição controle (água de coleta, $<0,5 \%$ S, 0 mOsm kg-1 $\mathrm{H}_{2} \mathrm{O}$, tempo $=0$ hora), a osmolalidade da hemolinfa foi de $390 \pm 10,6 \mathrm{mOsm} \mathrm{kg}^{-1} \mathrm{H}_{2} \mathrm{O}(\mathrm{X} \pm \mathrm{EPM}, \mathrm{N}=6)$ (Figura 33).

Ao longo do decurso temporal em água destilada $\left(0 \% \mathrm{~S}, 0 \mathrm{mOsm} \mathrm{kg}^{-1} \mathrm{H}_{2} \mathrm{O}\right)$, a ANOVA de 2-fatores indicou uma diminuição na osmolalidade da hemolinfa de $M$. jeslkii nos tempos de $5(\mathrm{P}=0,007)$ e 12 horas $(\mathrm{P}=0,002)$ em relação ao tempo $=0$. Os animais não sobreviveram a 24 horas de experimentação nessa condição de salinidade (Figura 33).

Já em água salobra $\left(20 \% \mathrm{~S}, 600 \mathrm{mOsm} \mathrm{kg}^{-1} \mathrm{H}_{2} \mathrm{O}\right)$, a ANOVA de 1-fator indicou efeito do tempo de exposição ( $\mathrm{P}<0,001)$. Verificamos elevação da osmolalidade da hemolinfa após 5 horas de exposição $(\mathrm{P}=0,001 \mathrm{SNK})$, a qual permaneceu até o tempo de 240 horas $(\mathrm{P}<$ 0,001 SNK). Em 12 horas de exposição, houve aumento significativo na osmolalidade da hemolinfa em relação ao tempo anterior de 5 horas ( $\mathrm{P}<0,001 \mathrm{SNK}$ ). A partir de 12 horas, a hemolinfa se manteve aproximadamente $50 \mathrm{mOsm} \mathrm{kg}^{-1} \mathrm{H}_{2} \mathrm{O}$ abaixo da osmolalidade do meio, mostrando discreta hipo-regulação (aproximadamente $550 \mathrm{mOsm} \mathrm{kg}^{-1} \mathrm{H}_{2} \mathrm{O}$ ). 


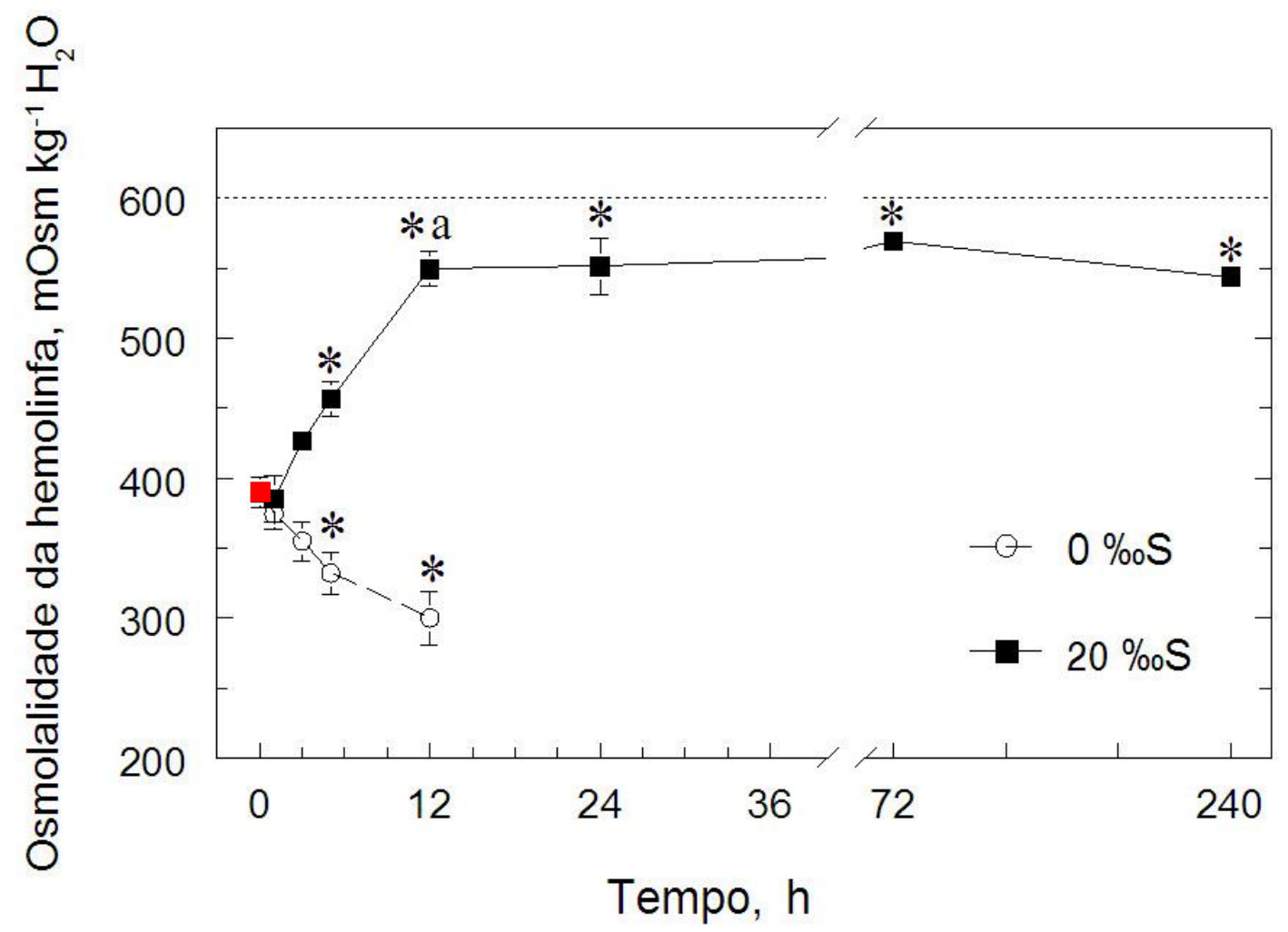

Figura 33. Decurso temporal da osmolalidade $\left(\mathrm{mOsm} \mathrm{kg}^{-1} \mathrm{H}_{2} \mathrm{O}\right)$ da hemolinfa de $M$. jelskii, nas salinidades de 0 \%oS (água destilada) e $20 \%$ S (água salobra), ao longo de até 10 dias de exposição $(\mathrm{X} \pm \mathrm{EPM}, 3 \leq \mathrm{N} \leq 7)$. Em água destilada, observa-se uma diminuição da osmolalidade da hemolinfa entre 5 e 12 horas. Os camarões não sobreviveram em tempos de exposição mais prolongados. Em água salobra, a osmolalidade aumenta a partir de 5 horas. *Significativamente diferente em relação ao grupo controle $(<0,5 \% \mathrm{~S}$, tempo $=0$, representado em vermelho). ${ }^{a}$ Diferença significativa em relação ao tempo imediatamente anterior, dentro da mesma salinidade. A linha pontilhada indica a osmolalidade da água a $20 \% \mathrm{~S}\left(600 \mathrm{mOsm} \mathrm{kg}^{-1} \mathrm{H}_{2} \mathrm{O}\right)$.

A osmolalidade da hemolinfa (em mOsm $\mathrm{kg}^{-1} \mathrm{H}_{2} \mathrm{O}$ ) nos diferentes tempos experimentais em água destilada $(0 \% \mathrm{~S})$ foi de: $374 \pm 10,7 \mathrm{em} 1$ hora $(\mathrm{N}=7), 355 \pm 13,8 \mathrm{em}$ 3 horas $(\mathrm{N}=6), 332 \pm 14,6$ em 5 horas $(\mathrm{N}=7)$ e $299 \pm 19,5$ em 12 horas $(\mathrm{N}=3)$.

Em água salgada $(20 \% \mathrm{~S})$, a osmolalidade da hemolinfa (mOsm kg-1 $\left.\mathrm{H}_{2} \mathrm{O}\right)$ nos diferentes tempos experimentais foi de: $385 \pm 16,8$ em 1 hora $(\mathrm{N}=6), 426 \pm 8,5 \mathrm{em} 3$ horas $(\mathrm{N}=6), 457 \pm 12,2$ em 5 horas $(\mathrm{N}=7), 549 \pm 12,5$ em 12 horas $(\mathrm{N}=4), 555 \pm 20,6 \mathrm{em} 24$ horas $(\mathrm{N}=6), 569 \pm 5,5$ em 72 horas $(\mathrm{N}=7)$ e $544 \pm 3,6$ em 240 horas $(\mathrm{N}=6)$.

\section{$\left[\mathrm{Cl}^{-}\right]$}

A ANOVA de dois fatores para decurso temporal de até 12 horas indicou efeito da salinidade e da interação salinidade $\mathrm{X}$ tempo de exposição $(\mathrm{P}<0,001)$. Porém, não houve efeito do tempo de exposição à salinidade $(\mathrm{P}=0,297)$ sobre a $\left[\mathrm{Cl}^{-}\right]$da hemolinfa em $M$. jelskii. 
Na condição controle (água doce, $<0,5 \% \mathrm{~S}, 7,7 \mathrm{mmol} \mathrm{L}^{-1}$, tempo $=0$ hora), a $\left[\mathrm{Cl}^{-}\right] \mathrm{da}$ hemolinfa foi de $173 \pm 6,1 \mathrm{mmol} \mathrm{L}^{-1}(\mathrm{X} \pm \mathrm{EPM}, \mathrm{N}=5$ ) (Figura 34).

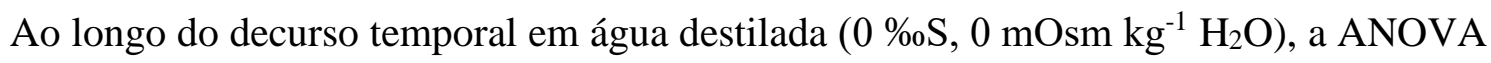
de 2-fatores indicou uma diminuição na $\left[\mathrm{Cl}^{-}\right]$da hemolinfa de $M$. jelskii nos tempos de 5 (P < 0,001 SNK) e 12 horas $(\mathrm{P}<0,001 \mathrm{SNK})$ em relação ao tempo $=0$ (Figura 34).

Já em água salobra $\left(20 \% \mathrm{~S}, 320 \mathrm{mmol} \mathrm{L}^{-1}\right)$, a ANOVA de 1-fator indicou efeito do tempo de exposição $(\mathrm{P}<0,001)$. Verificamos elevação estatisticamente significativa da $\left[\mathrm{Cl}^{-}\right]$ após 5 horas de exposição ( $\mathrm{P}=0,001 \mathrm{SNK})$, que se manteve até 240 horas ( $\mathrm{P}<0,001 \mathrm{SNK})$. Em 12 horas, houve aumento significativo na $\left[\mathrm{Cl}^{-}\right]$da hemolinfa em relação ao tempo imediatamente anterior de 5 horas $(\mathrm{P}<0,001 \mathrm{SNK})$. Mesmo nos tempos mais tardios (72 e 240 horas), a hemolinfa se manteve claramente hipo-regulada, em torno de $70 \mathrm{mmol} \mathrm{L}^{-1}$ abaixo da $\left[\mathrm{Cl}^{-}\right]$do meio externo (320 $\left.\mathrm{mmol} \mathrm{L}^{-1}\right)$ (Figura 34).

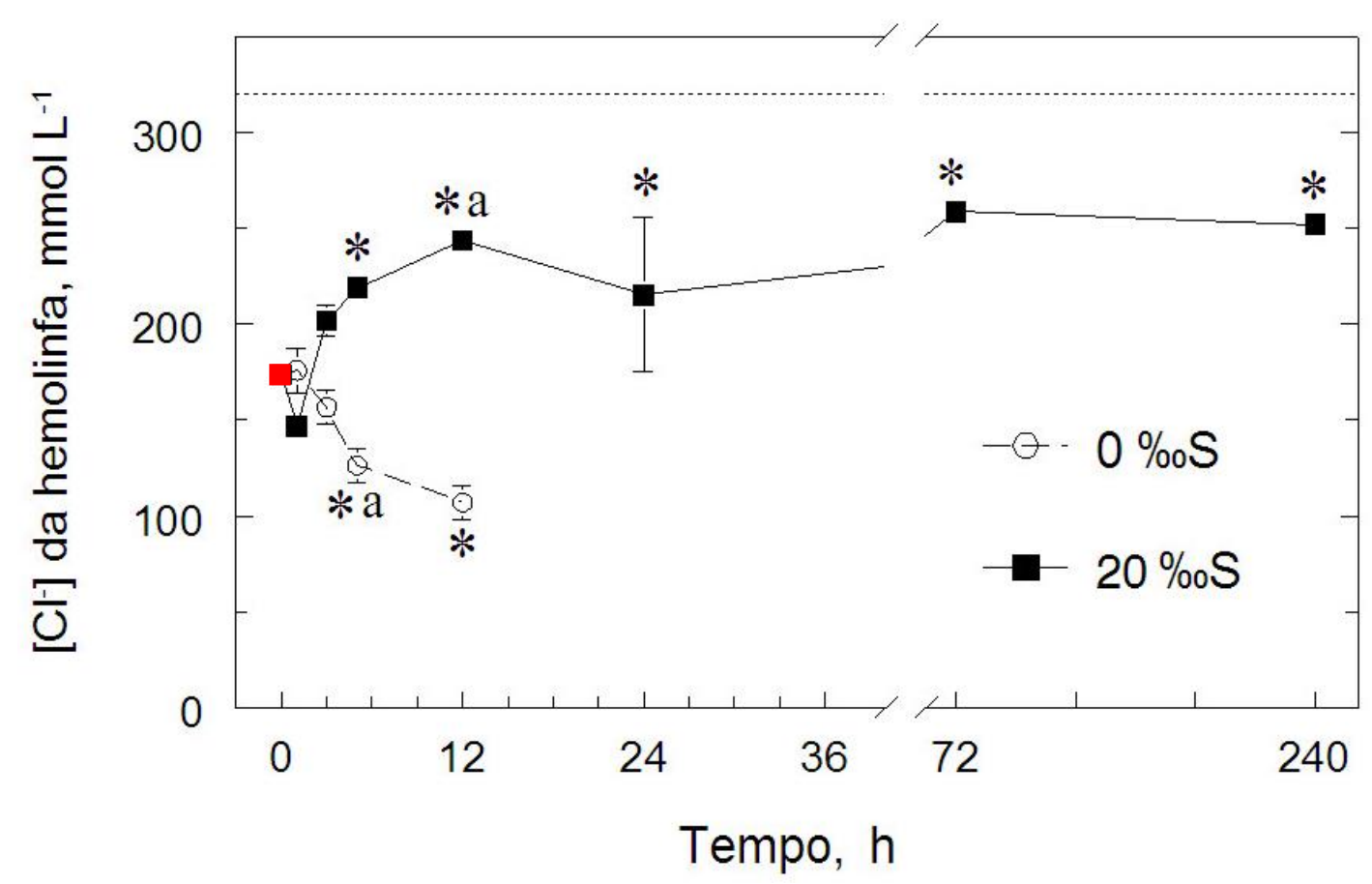

Figura 34. Decurso temporal da $\left[\mathrm{Cl}^{-}\right]\left(\mathrm{mmol} \mathrm{L}^{-1}\right)$ da hemolinfa de $M$. jelskii, nas salinidades de $0 \% \mathrm{o}$ (água destilada) e $20 \% \mathrm{~S}$ (água salobra), ao longo de até 10 dias de exposição $(\mathrm{X} \pm \mathrm{EPM}, 3 \leq \mathrm{N} \leq 8)$. Em água destilada, observa-se uma diminuição da $\left[\mathrm{Cl}^{-}\right]$da hemolinfa entre 5 e 12 horas. Os camarões não sobreviveram em tempos de exposição mais prolongados. Em água salobra, a [ $\left.\mathrm{Cl}^{-}\right]$aumenta a partir de 3 horas. *Significativamente diferente em relação ao grupo controle $(<0,5 \%$ S, tempo $=0$, representado em vermelho). aDiferença significativa em relação ao tempo imediatamente anterior, dentro da mesma salinidade. A linha pontilhada indica a $\left[\mathrm{Cl}^{-}\right]$da água a $20 \% \mathrm{~S}\left(320 \mathrm{mmol} \mathrm{L}^{-1}\right)$. 
A $\left[\mathrm{Cl}^{-}\right]$da hemolinfa (em mmol $\left.\mathrm{L}^{-1}\right)$ nos diferentes tempos experimentais em água destilada $(0 \% \mathrm{~S})$ foi de: $176 \pm 11,6 \mathrm{em} 1$ hora $(\mathrm{N}=6), 157 \pm 8,8 \mathrm{em} 3$ horas $(\mathrm{N}=5), 126 \pm$ 8,7 em 5 horas $(\mathrm{N}=6)$ e $107 \pm 8,9$ em 12 horas $(\mathrm{N}=3)$.

Em água salgada $(20 \% \mathrm{~S})$, a $\left[\mathrm{Cl}^{-}\right]$da hemolinfa $\left(\mathrm{mmol} \mathrm{L}^{-1}\right)$ nos diferentes tempos experimentais foi de: $147 \pm 6,9$ em 1 hora $(\mathrm{N}=4), 202 \pm 7,7 \mathrm{em} 3$ horas $(\mathrm{N}=5), 219 \pm 6,1$ em 5 horas $(\mathrm{N}=6), 244 \pm 7,1 \mathrm{em} 12$ horas $(\mathrm{N}=5), 215 \pm 40,2 \mathrm{em} 24$ horas $(\mathrm{N}=6), 259 \pm 2,8$ em 72 horas $(\mathrm{N}=8)$ e $252 \pm 7,2$ em 240 horas $(\mathrm{N}=6)$.

\section{$\left[\mathrm{Na}^{+}\right]$}

A ANOVA de dois fatores para decurso temporal de até 12 horas indicou efeito da salinidade e da interação salinidade $X$ tempo de exposição $(P<0,001)$, porém não houve efeito do tempo de exposição $(\mathrm{P}=0,761)$ sobre a $\left[\mathrm{Na}^{+}\right]$da hemolinfa em M. jelskii.

$\mathrm{Na}$ condição controle (água doce, $<0,5 \% \mathrm{~S}, 6,8 \mathrm{mmol} \mathrm{L}-1$, tempo $=0$ hora), a $\left[\mathrm{Na}^{+}\right] \mathrm{da}$ hemolinfa foi de $173 \pm 10,0 \mathrm{mmol} \mathrm{L}^{-1}(\mathrm{X} \pm \mathrm{EPM}, \mathrm{N}=8)$ (Figura 35).

Ao longo do decurso temporal em água destilada $(0 \% \mathrm{~S})$, a ANOVA de 2-fatores indicou diminuição na $\left[\mathrm{Na}^{+}\right]$da hemolinfa de $M$. jelskii entre os tempos de $5(\mathrm{P}=0,002 \mathrm{SNK})$ e 12 horas de exposição ( $\mathrm{P}=0,001 \mathrm{SNK}$ ) (Figura 35).

Em água salobra $\left(20 \% \mathrm{~S}, 280 \mathrm{mmol} \mathrm{L}^{-1}\right)$, a ANOVA de 1-fator indicou efeito do tempo de exposição $(\mathrm{P}<0,001)$. Verificamos elevação da $\left[\mathrm{Na}^{+}\right]$da hemolinfa após 5 horas de exposição ( $\mathrm{P}<0,001 \mathrm{SNK})$, que se manteve até 240 horas $(\mathrm{P}<0,001 \mathrm{SNK})$. Em 5 horas de exposição, houve aumento na $\left[\mathrm{Na}^{+}\right]$da hemolinfa em relação ao tempo imediatamente anterior de 3 horas $(\mathrm{P}=0,014 \mathrm{SNK})$. Embora a $\left[\mathrm{Na}^{+}\right]$tenha aumentado ao longo do decurso temporal, após 24 horas a hemolinfa se manteve levemente hipo-regulada, em torno de 30 mmol L ${ }^{-1}$ abaixo da $\left[\mathrm{Na}^{+}\right]$do meio externo $\left(280 \mathrm{mmol} \mathrm{L}^{-1}\right)$ (Figura 35). 


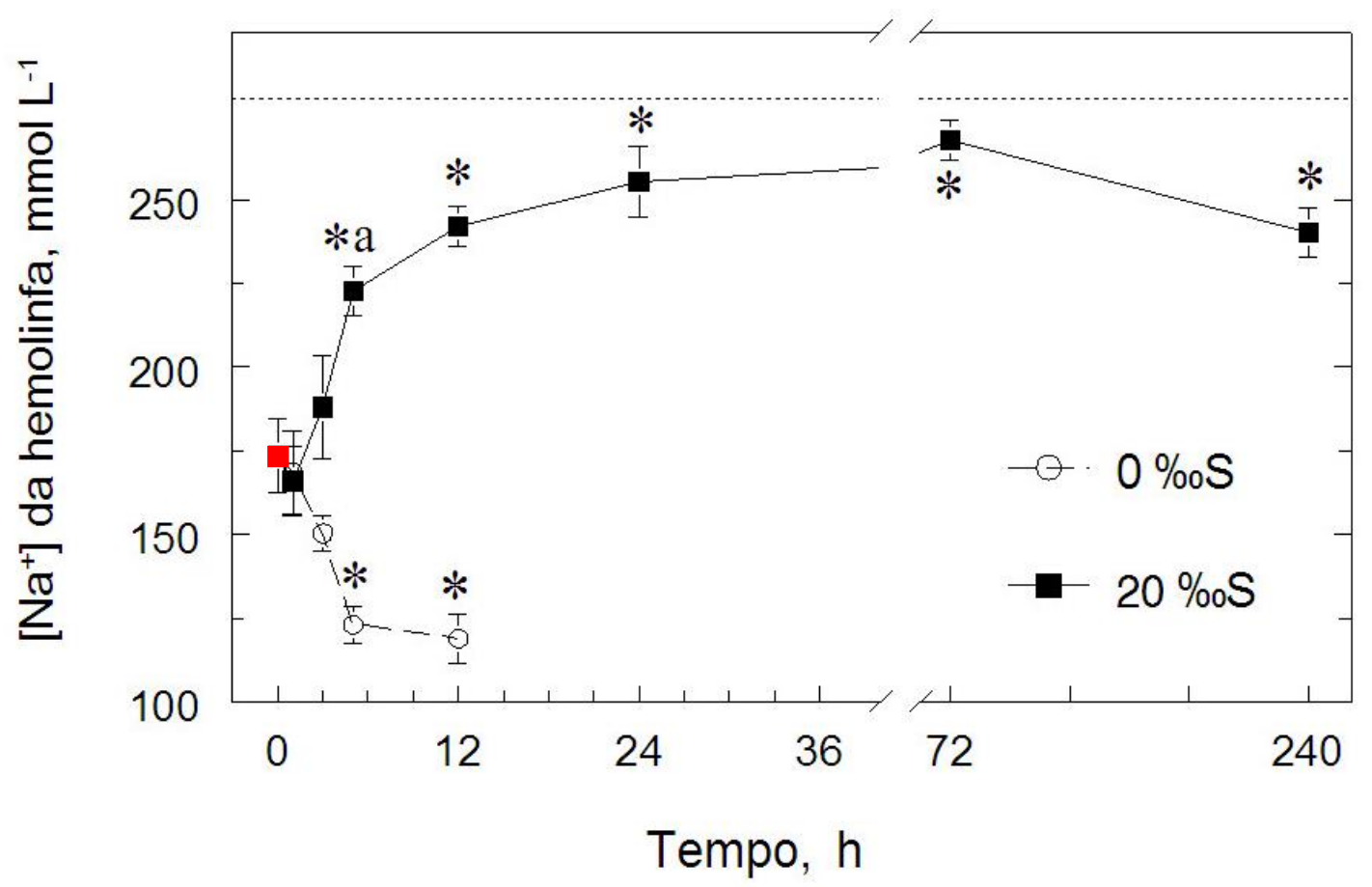

Figura 35. Decurso temporal da $\left[\mathrm{Na}^{+}\right]\left(\mathrm{mmol} \mathrm{L}^{-1}\right)$ da hemolinfa de $M$. jelskii, nas salinidades de $0 \% \mathrm{o}$ (água destilada) e $20 \% \mathrm{~S}$ (água salgada), ao longo de até 10 dias de exposição ( $\pm \mathrm{EPM}, 5 \leq \mathrm{N} \leq 9)$. Em água destilada, observa-se que a $\left[\mathrm{Na}^{+}\right]$diminuiu entre os tempos de 5 a 12 horas. Os camarões não sobreviveram em tempos de exposição mais prolongados. Em água salobra, a $\left[\mathrm{Na}^{+}\right]$aumenta a partir de 5 horas. *Significativamente diferente em relação ao grupo controle $(<0,5 \% \mathrm{~S}$, tempo $=0$, representado em vermelho). aDiferença significativa em relação ao tempo imediatamente anterior, dentro da mesma salinidade. A linha pontilhada indica a $\left[\mathrm{Na}^{+}\right]$da água a $20 \% \mathrm{~S}\left(280 \mathrm{mmol} \mathrm{L}^{-1}\right)$.

A $\left[\mathrm{Na}^{+}\right]$da hemolinfa $\left(\mathrm{em} \mathrm{mmol} \mathrm{L} \mathrm{L}^{-1}\right)$ nos diferentes tempos experimentais em água destilada $(0 \% \mathrm{~S})$ foi de: $168 \pm 12,6$ e 1 hora $(\mathrm{N}=5), 150 \pm 5,3$ em 3 horas $(\mathrm{N}=5), 123 \pm 5,4$ em 5 horas $(\mathrm{N}=7)$ e $119 \pm 7,3$ em 12 horas $(\mathrm{N}=7)$.

Em água salobra $(20 \% \mathrm{~S})$, a $\left[\mathrm{Na}^{+}\right]\left(\mathrm{mmol} \mathrm{L}^{-1}\right)$ nos diferentes tempos experimentais foi de: $166 \pm 10,3$ em 1 hora $(\mathrm{N}=6), 188 \pm 15,6$ em 3 horas $(\mathrm{N}=6), 222 \pm 7,8 \mathrm{em} 5$ horas $(\mathrm{N}=$ 8), $242 \pm 5,9$ em 12 horas $(\mathrm{N}=5), 255 \pm 10,7 \mathrm{em} 24$ horas $(\mathrm{N}=6), 268 \pm 5,9$ em 72 horas $(\mathrm{N}$ $=8)$ e $240 \pm 7,4$ em 240 horas $(\mathrm{N}=9)$.

\subsubsection{Análises das expressões dos ionotransportadores por qPCR em brânquias de}

\section{M.jelskii}

\section{Expressão gênica da subunidade B da V( $\left(H^{+}\right)$-ATPase}

A ANOVA de dois fatores até 12 horas do decurso temporal indicou efeito do tempo de exposição $(\mathrm{P}<0,001)$ e da salinidade $(\mathrm{P}=0,006)$ sobre a expressão de RNA mensageiro da subunidade $\mathrm{B}$ da $\mathrm{V}\left(\mathrm{H}^{+}\right)$-ATPase em $M$. jelskii. Porém não indicou efeito da interação 
salinidade $\mathrm{X}$ tempo de exposição $(\mathrm{P}=0,115)$. Para a análise estatística, os valores de expressão foram transformados pela função $\log _{10} \mathrm{X}$.

Ao longo do decurso temporal em água destilada $(0 \% \mathrm{\%})$, a ANOVA de 2-fatores indicou aumento de 1,6 a 2 vezes na expressão da $\mathrm{V}\left(\mathrm{H}^{+}\right)$-ATPase em relação ao grupo controle (água doce, $<0,5 \% \mathrm{~S}$, tempo $=0, \mathrm{~N}=4$ ), desde a primeira hora $(\mathrm{P}<0,001 \mathrm{SNK}) \mathrm{de}$ incubação até 12 horas (P < 0,001 SNK) (Figura 36).

Em água salobra $(20 \% \mathrm{~S})$, a ANOVA de 1-fator indicou efeito do tempo de exposição $(\mathrm{P}<0,001)$. Verificamos aumento de 2 a 3 vezes na expressão da $\mathrm{V}\left(\mathrm{H}^{+}\right)$-ATPase, entre $3(\mathrm{P}<$ 0,001 SNK) a 12 horas $(\mathrm{P}=0,003 \mathrm{SNK})$ de exposição em relação ao controle $(\mathrm{N}=4)$. A partir de 24 horas, a expressão voltou a se igualar à condição controle $(\mathrm{P}=0,151 \mathrm{SNK})$ (Figura 36).

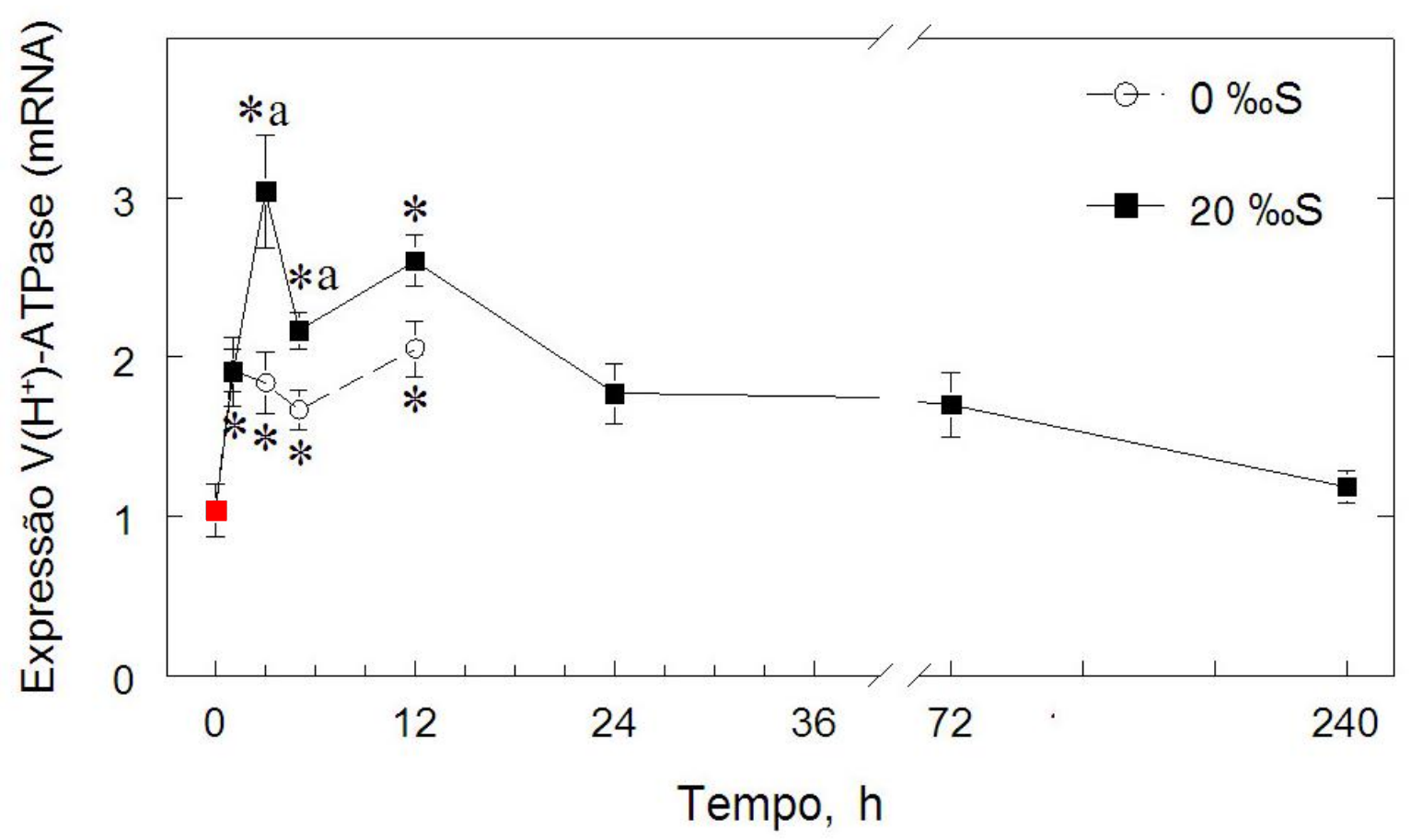

Figura 36. Decurso temporal do efeito da aclimatação às salinidades de 0 (água destilada) ou $20 \% \mathrm{O}$ sobre a expressão de mRNA da subunidade $\mathrm{B}$ da $\mathrm{V}\left(\mathrm{H}^{+}\right)$-ATPase branquial de $M$. jelskii $(\mathrm{X} \pm \mathrm{EPM}, 4 \leq \mathrm{N} \leq 7)$. A análise quantitativa foi realizada por PCR em Tempo Real e a expressão da $\mathrm{V}\left(\mathrm{H}^{+}\right)$-ATPase foi normalizada pela expressão do gene PRL10 (constitutiva), em cada amostra. Os valores finais representam a taxa de expressão relativa do gene em cada intervalo de tempo a 0 ou $20 \% \mathrm{~S}$, em relação ao grupo controle $(<0,5 \% \mathrm{~S}$, tempo $=0$, representado em vermelho), utilizado como calibrador. *Significativamente diferente em relação ao grupo

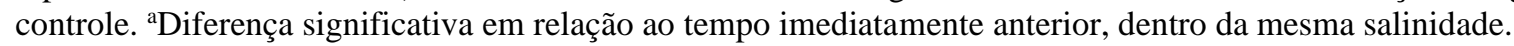

\section{Expressão gênica da subunidade $\alpha$ da $\mathrm{Na}^{+} / \mathrm{K}^{+}$-ATPase}

A ANOVA de dois fatores até 12 horas do decurso temporal indicou efeito do tempo de exposição $(\mathrm{P}=0,003)$, da salinidade $(\mathrm{P}<0,001)$ e da interação da salinidade $\mathrm{X}$ tempo de 
exposição $(\mathrm{P}=0,005)$ sobre a expressão de RNA mensageiro da subunidade $\alpha$ da $\mathrm{Na}^{+} / \mathrm{K}^{+}$ATPase em brânquias de $M$. jelskii. Embora nossos dados tenham passado no teste de normalidade $(P=0,011)$, não passaram no teste de igualdade variância $(P=0,010)$. No entanto, como a ANOVA é um teste muito robusto, demos continuidade às análises da mesma forma que para com os demais parâmetros avaliados nesse estudo.

Ao longo do decurso temporal em água destilada $(0 \% \mathrm{O})$, a ANOVA de 2-fatores não detectou mudanças significativas na expressão da $\mathrm{Na}^{+} / \mathrm{K}^{+}$-ATPase em relação ao grupo controle (água doce, $<0,5 \% \mathrm{~S}$, tempo $=0, \mathrm{~N}=4$ ), embora haja uma tendência de aumento em 12 horas $(\mathrm{P}=0,153 \mathrm{SNK})$ (Figura 37).

Em água salobra $(20 \% \mathrm{~S})$, a ANOVA de 1-fator indicou efeito do tempo de exposição ( $\mathrm{P}<0,001)$. Verificamos aumento na expressão da $\mathrm{Na}^{+} / \mathrm{K}^{+}$-ATPase, de 3 a 4 vezes, a partir de 1 hora de exposição $(\mathrm{P}=0,02 \mathrm{SNK})$ em relação ao grupo controle (água doce, $<0,5 \% \mathrm{~S}$, tempo $=0, \mathrm{~N}=4)$, que se mantiveram até 5 horas $(\mathrm{P}=0,037 \mathrm{SNK})$. A partir de 12 horas, a expressão voltou a se igualar à condição controle ( $\mathrm{P}=0,108$ SNK) (Figura 37).

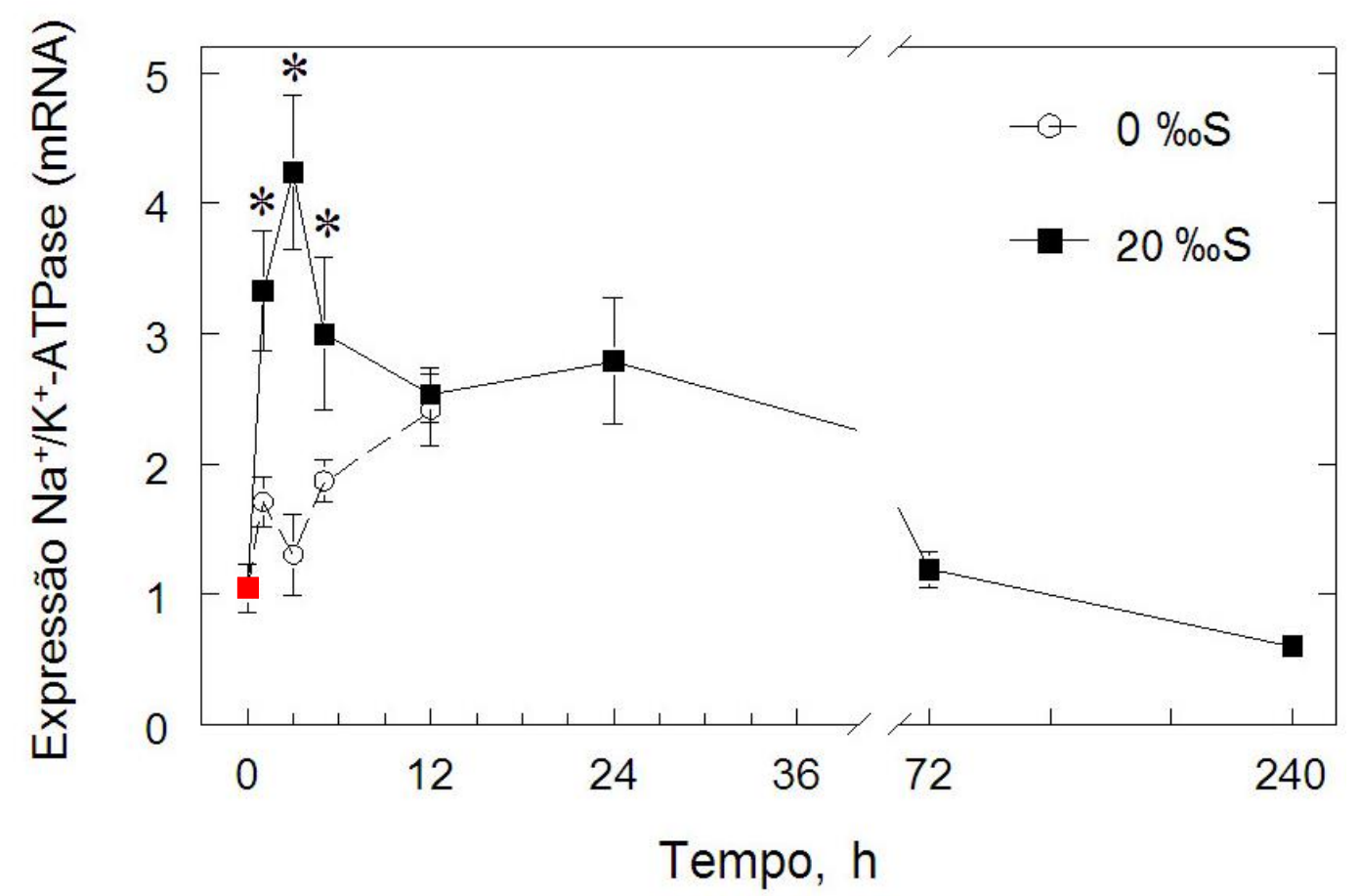

Figura 37. Decurso temporal do efeito da aclimatação às salinidades de 0 (água destilada) ou $20 \%{ }_{0} \mathrm{~S}$ sobre a expressão de mRNA da subunidade $\alpha$ da $\mathrm{Na}^{+} / \mathrm{K}^{+}$-ATPase branquial de $M$. jelskii $(\mathrm{X} \pm \mathrm{EPM}, 4 \leq \mathrm{N} \leq 7)$. A análise quantitativa foi realizada por PCR em Tempo Real e a expressão da $\mathrm{Na}^{+} / \mathrm{K}^{+}$-ATPase foi normalizada pela expressão do gene PRL10 (constitutiva), em cada amostra. Os valores finais representam a taxa de expressão relativa do gene em cada intervalo de tempo a 0 ou $20 \% \mathrm{~S}$, em relação ao grupo controle $(<0,5 \% \mathrm{~S}$, tempo $=0$, representado em vermelho), utilizado como calibrador. *Significativamente diferente em relação ao grupo controle. 


\section{Expressão gênica do simportador $\mathrm{Na}^{+} / \mathrm{K}^{+} / 2 \mathrm{Cl}^{-}$}

A ANOVA de dois fatores até 12 horas de decurso temporal indicou efeito do tempo de exposição $(\mathrm{P}<0,001)$, da salinidade $(\mathrm{P}<0,001)$ e do efeito da interação da salinidade $\mathrm{X}$ tempo de exposição $(\mathrm{P}=0,043)$ sobre a expressão de RNA mensageiro do simportador $\mathrm{Na}^{+} / \mathrm{K}^{+} / 2 \mathrm{Cl}^{-}$em brânquias de $M$. jelskii. Para a análise estatística, os valores de expressão foram transformados pela função $\log _{10} \mathrm{X}$.

Ao longo do decurso temporal em água destilada $(0 \% \mathrm{~S})$, a ANOVA de 2-fatores detectou aumentos de 3 a 5 vezes na expressão do simportador $\mathrm{Na}^{+} / \mathrm{K}^{+} / 2 \mathrm{Cl}^{-}$, desde a primeira hora de incubação $(\mathrm{P}=0,002 \mathrm{SNK})$ até 12 horas $(\mathrm{P}<0,001 \mathrm{SNK})$ em relação ao grupo controle (água doce, $<0,5 \% \mathrm{~S}$, tempo $=0, \mathrm{~N}=4$ ) (Figura 38).

Em água salobra $(20 \%$ S), a ANOVA de 1-fator indicou efeito do tempo de exposição $(\mathrm{P}<0,001)$. Verificamos aumento de 3,5 a 12 vezes na expressão do simportador $\mathrm{Na}^{+} / \mathrm{K}^{+} / 2 \mathrm{Cl}^{-}$ desde a primeira hora de incubação $(\mathrm{P}=0,001 \mathrm{SNK})$ até o tempo mais tardio de exposição do decurso temporal, 240 horas $(\mathrm{P}=0,010 \mathrm{SNK})$, em relação à condição controle (água doce, $<$ $0,5 \%$ S, tempo $=0, \mathrm{~N}=4)($ Figura 38$)$.

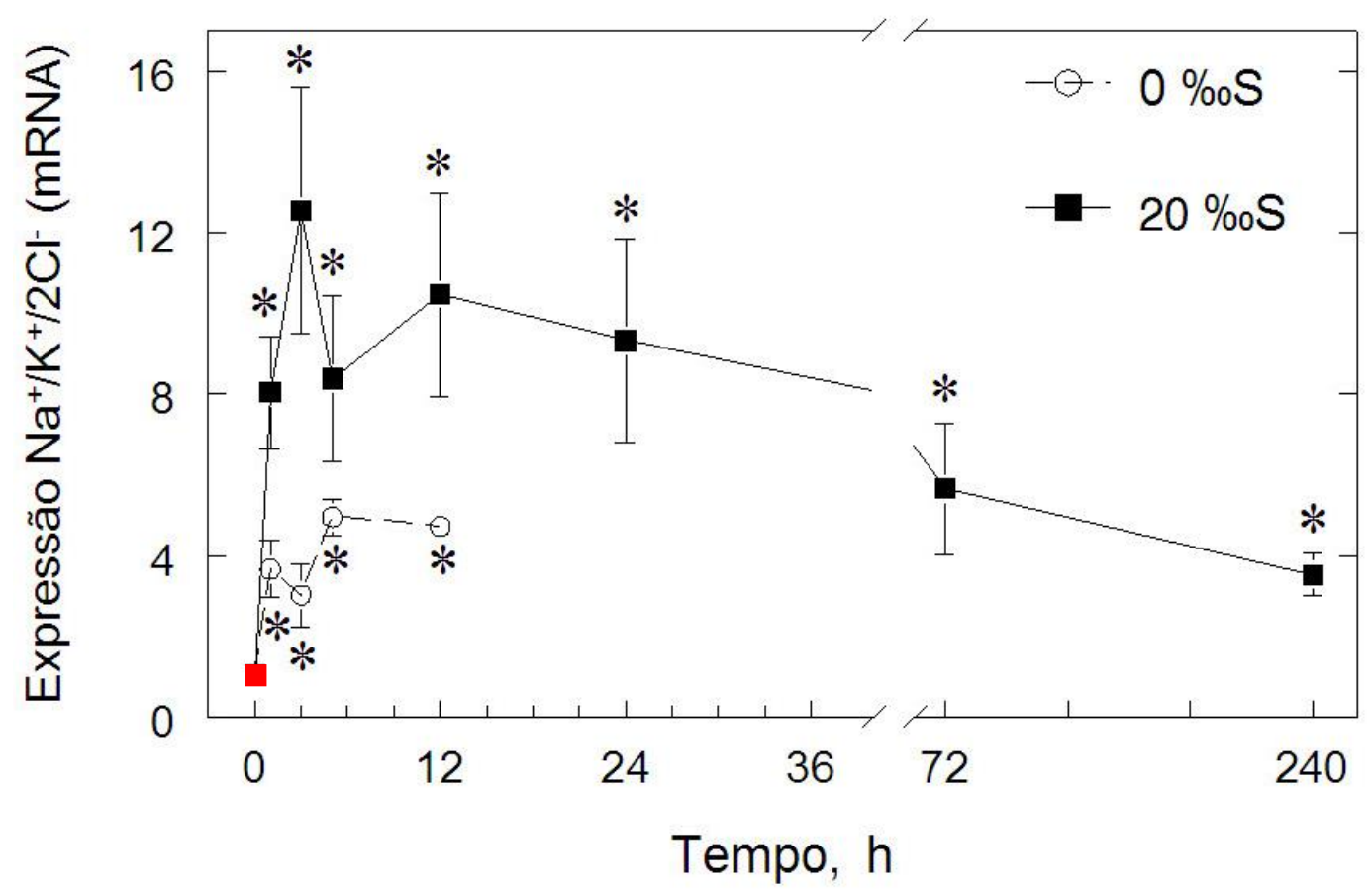

Figura 38. Decurso temporal do efeito da aclimatação às salinidades de 0 (água destilada) ou $20 \% \mathrm{O}$ sobre a expressão de mRNA do simportador $\mathrm{Na}^{+} / \mathrm{K}^{+} / 2 \mathrm{Cl}^{-}$branquial de $M$. jelskii $(\mathrm{X} \pm \mathrm{EPM}, 4 \leq \mathrm{N} \leq 7)$. A análise quantitativa foi realizada por PCR em Tempo Real e a expressão do simportador $\mathrm{Na}^{+} / \mathrm{K}^{+} / 2 \mathrm{Cl}^{-}$foi normalizada pela expressão do gene PRL10 (constitutiva), em cada amostra. Os valores finais representam a taxa de expressão relativa do gene em cada intervalo de tempo a 0 ou $20 \% \mathrm{~S}$, em relação ao grupo controle $(<0,5 \% \mathrm{~S}$, tempo $=0$, representado em vermelho), utilizado como calibrador. *Significativamente diferente em relação ao grupo controle. 


\subsubsection{Quantificacão da expressão proteica em brânquias de $M$. jelskii}

\section{Expressão proteica do ionotransportador $\mathrm{Na}^{+} / \mathrm{K}^{+}$-ATPase}

A ANOVA de dois fatores até 12 horas de decurso temporal não indicou efeito do tempo de exposição $(\mathrm{P}=0,583)$, nem da salinidade $(\mathrm{P}=0,539)$ e tampouco do efeito da interação da salinidade $X$ tempo de exposição $(P=0,731)$ sobre a expressão proteica da $\mathrm{Na}^{+} / \mathrm{K}^{+}$-ATPase em brânquias de $M$. jelskii (Figura 39).

Embora a Figura 39 ilustre que a expressão ao longo do decurso temporal em água salobra $(20 \% \mathrm{~S})$ tenda a diminuir, não foram detectadas quaisquer mudanças significativas na expressão proteica de $\mathrm{Na}^{+} / \mathrm{K}^{+}$-ATPase nos grupos experimentais, em relação ao grupo controle (água doce, $<0,5 \% \mathrm{~S}$, tempo $=0, \mathrm{~N}=4$ ).

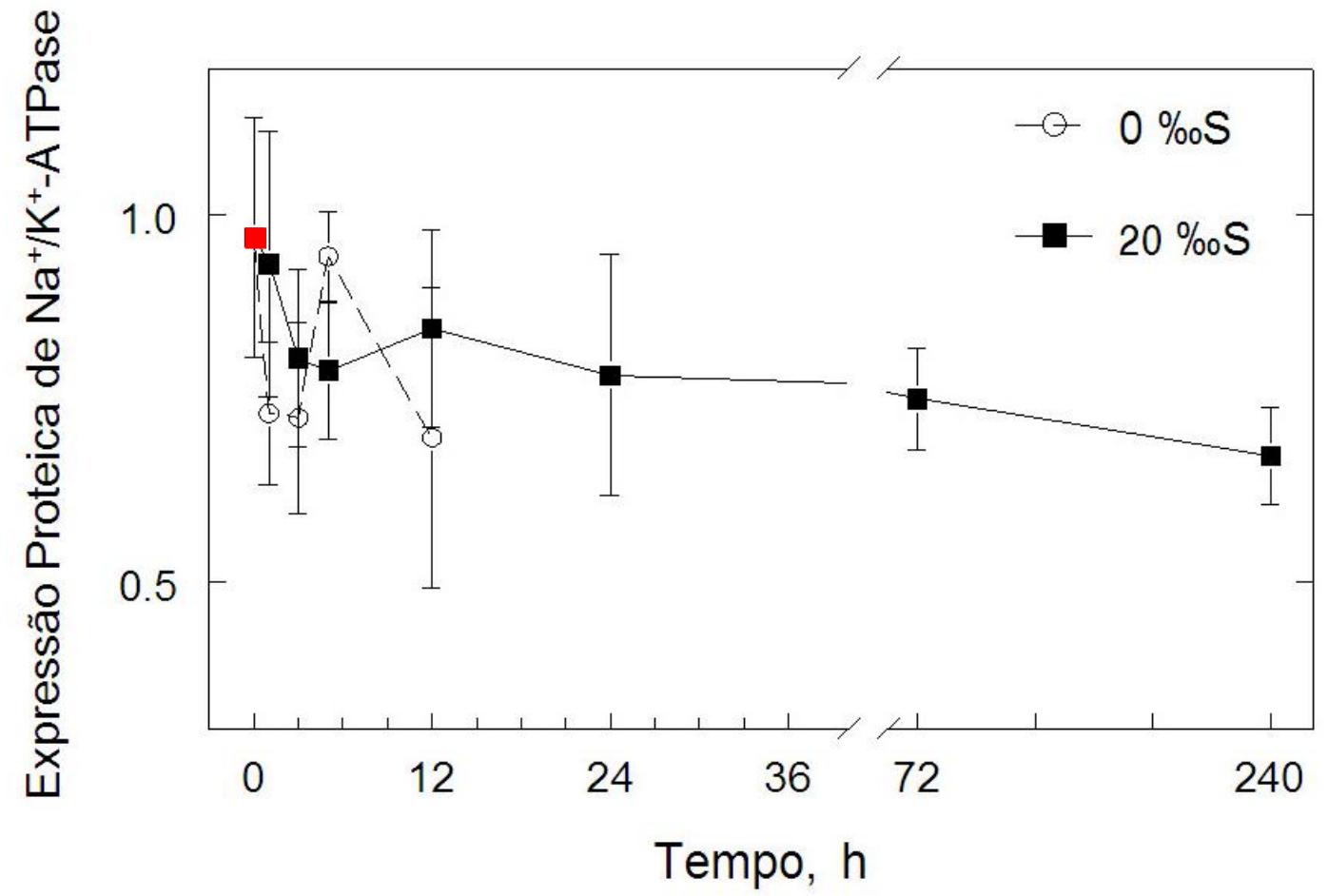

Figura 39. Decurso temporal do efeito da aclimatação às salinidades de 0 (água destilada) ou $20 \% \mathrm{O}$ sobre a expressão proteica de $\mathrm{Na}^{+} / \mathrm{K}^{+}$-ATPase branquial de M. jelskii $(\mathrm{X} \pm \mathrm{EPM}, 3 \leq \mathrm{N} \leq 9)$. A análise foi realizada por western blotting e a expressão da proteína de interesse foi normalizada pela expressão proteica da $\beta$-actina (constitutiva), em cada amostra. Os valores finais representam a taxa de expressão proteica em cada intervalo de tempo a 0 ou $20 \% \mathrm{~S}$, em relação ao grupo controle (representado em vermelho).

\section{Expressão proteica do simportador $\mathrm{Na}^{+} / \mathrm{K}^{+} / 2 \mathrm{Cl}^{-}$}

A ANOVA de dois fatores até 12 horas de decurso temporal não indicou efeito do tempo de exposição $(\mathrm{P}=0,557)$, nem da salinidade $(\mathrm{P}=0,575)$ e tampouco do efeito da 
interação da salinidade $X$ tempo de exposição $(P=0,819)$ sobre a expressão proteica da $\mathrm{Na}^{+} / \mathrm{K}^{+} / 2 \mathrm{Cl}^{-}$em brânquias de $M$. jelskii (Figura 40 ).

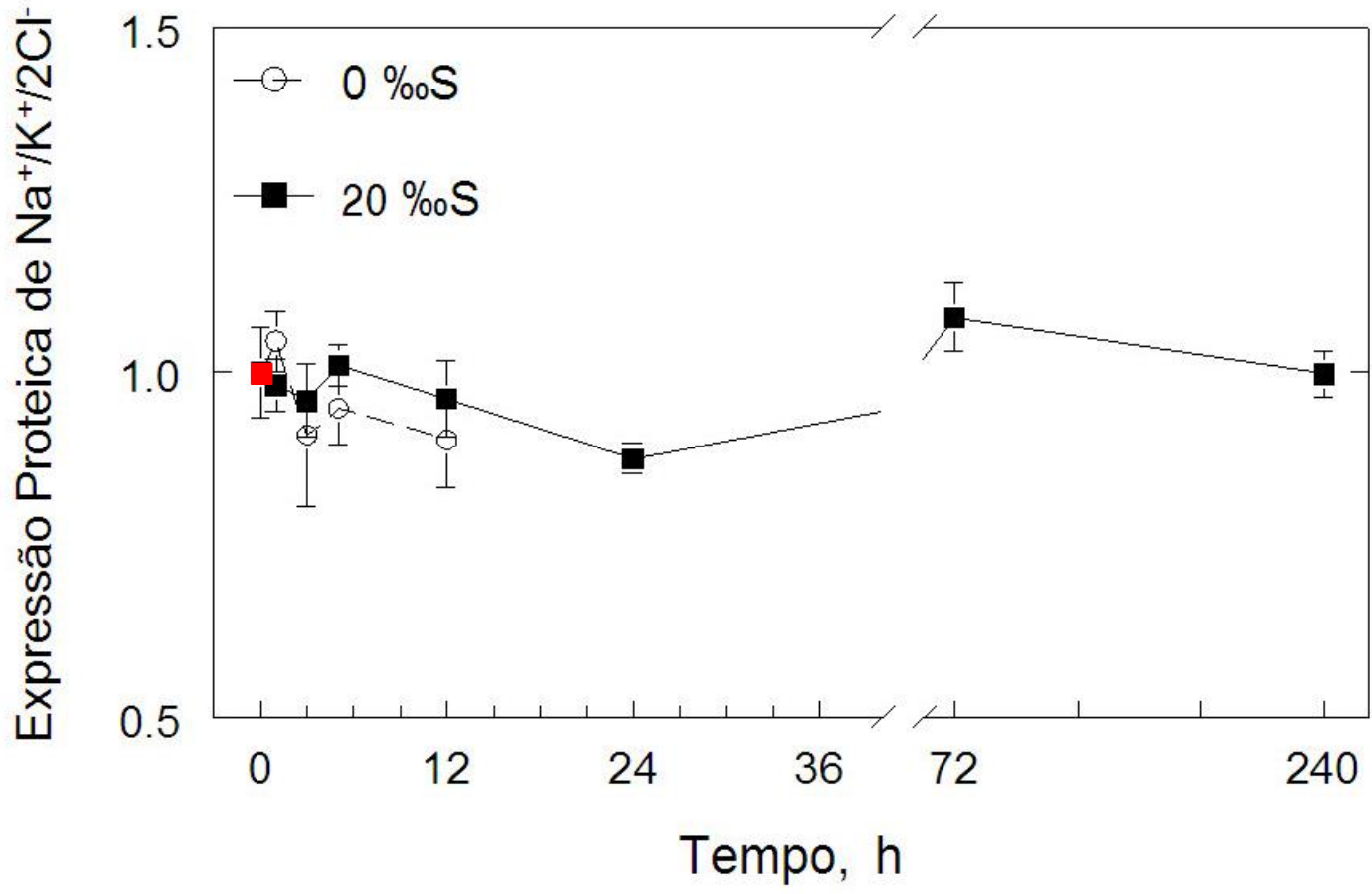

Figura 40. Decurso temporal do efeito da aclimatação às salinidades de 0 (água destilada) ou $20 \%{ }_{0} \mathrm{~S}$ sobre a expressão proteica de $\mathrm{Na}^{+} / \mathrm{K}^{+} / 2 \mathrm{Cl}^{-}$branquial de $M$. jelskii $(\mathrm{X} \pm \mathrm{EPM}, 4 \leq \mathrm{N} \leq 8)$. A análise foi realizada por western blotting e a expressão da proteína de interesse foi normalizada pela expressão proteica da $\beta$-actina (constitutiva), em cada amostra. Os valores finais representam a taxa de expressão proteica em cada intervalo de tempo a 0 ou $20 \% \mathrm{~S}$, em relação ao grupo controle (representado em vermelho).

Embora a expressão gênica do simportador $\mathrm{Na}^{+} / \mathrm{K}^{+} / 2 \mathrm{Cl}^{-}$tenha aumentado significativamente com a exposição em água destilada $(0 \% \mathrm{~S})$ e, principalmente em água salobra $(20 \% \mathrm{~S})$ (Figura 38), não foram detectadas quaisquer mudanças significativas na expressão proteica de $\mathrm{Na}^{+} / \mathrm{K}^{+} / 2 \mathrm{Cl}^{-}$nos grupos experimentais, em relação ao grupo controle (água doce, $<0,5 \% \mathrm{~S}$, tempo $=0, \mathrm{~N}=6$ ) ao longo do decurso temporal.

\subsubsection{Correlacão entre as expressões gênica e proteica de $M$. jelskii}

Apesar da ausência de alteração na expressão proteica da $\mathrm{Na}^{+} / \mathrm{K}^{+}$-ATPase e do $\mathrm{Na}^{+} / \mathrm{K}^{+} / 2 \mathrm{Cl}^{-}$em $M$. jelskii em qualquer condição experimental (decurso temporal em água destilada ou salobra), analisamos a relação entre a expressão gênica e proteica nessa espécie e nas diferentes condições experimentais.

Como visto na Figura 41, não houve nenhuma correlação forte (coeficiente de correlação de Pearson, $\mathrm{R}>0,7$ ou $\mathrm{R}<-0,7)$ entre as expressões gênica e proteica de $\mathrm{Na}^{+} / \mathrm{K}^{+}$ATPase em nenhuma das condições experimentais, em tecido branquial de $M$. jelskii. No 
decurso temporal em água destilada $(0 \% \mathrm{~S})$ o coeficiente de correlação de Pearson foi de $\mathrm{R}=$ 0,223 . No decurso temporal em salinidade de $20 \%$ S esse coeficiente foi de $\mathrm{R}=0,226$.

Também notamos ausência de correlação entre as expressões gênica e proteica do simportador $\mathrm{Na}^{+} / \mathrm{K}^{+} / 2 \mathrm{Cl}^{-}$nas diferentes condições experimentais, em tecido branquial de $M$. jelskii (Figura 42). No decurso temporal em água destilada $(0 \% \mathrm{~S})$ o coeficiente de correlação de Pearson foi de $\mathrm{R}=-0,286$. No decurso temporal em salinidade de $20 \% \mathrm{~S}$ esse coeficiente foi de $R=-0,473$.

\section{$\mathrm{Na}^{+} / \mathrm{K}^{+}$-ATPase}
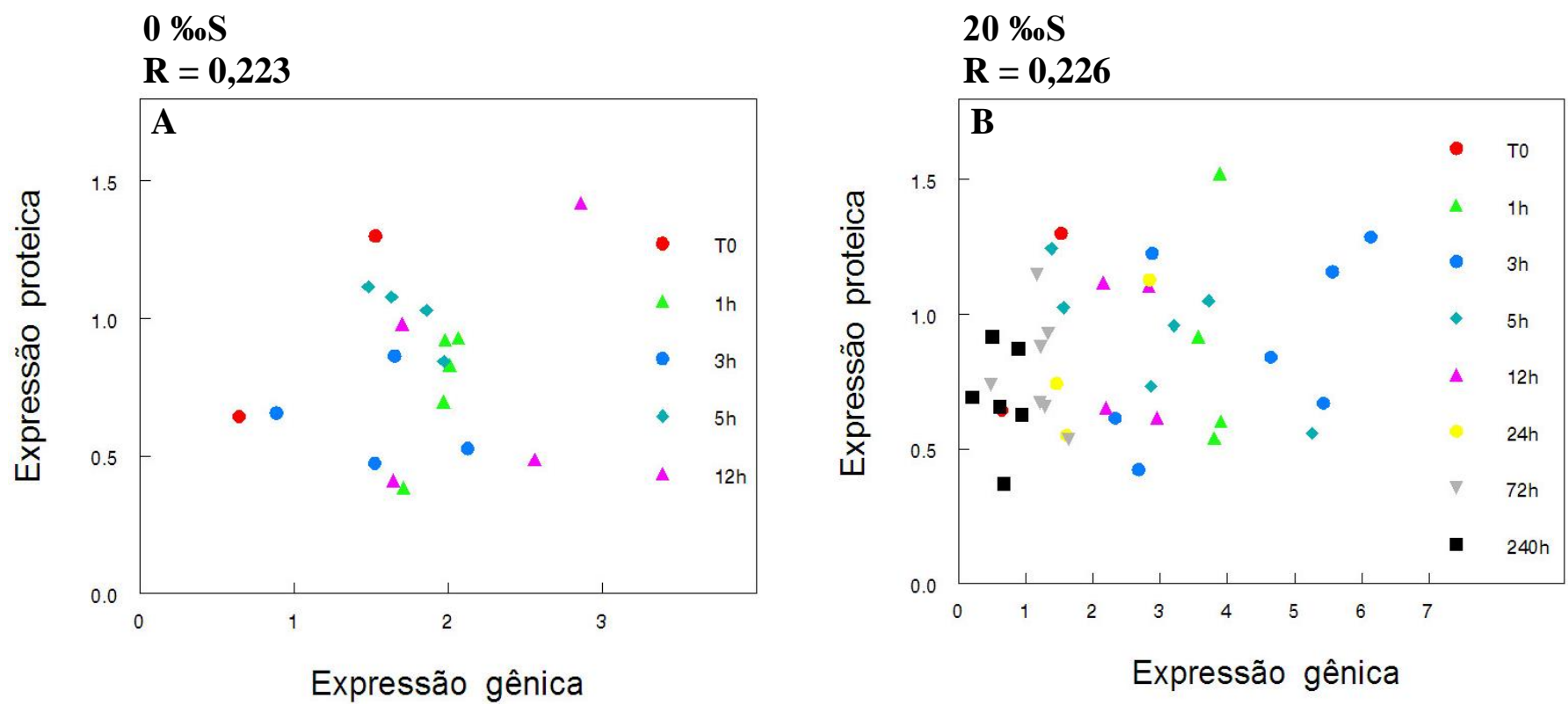

Figura 41. Correlações de Pearson entre as expressões gênica e proteica de $\mathrm{Na}^{+} / \mathrm{K}^{+}$-ATPase em brânquias do camarão de água doce Macrobrachium jelskii. A) Dados das expressões em brânquias de camarões submetidos ao decurso temporal em água destilada $(0 \% \mathrm{~S})(\mathrm{R}=0,223)$. B) Dados das expressões em brânquias de camarões submetidos ao decurso temporal na salinidade de $20 \% \mathrm{~S}(\mathrm{R}=0,226)$. 


\section{$\mathrm{Na}^{+} / \mathrm{K}^{+} / 2 \mathrm{Cl}^{-}$}
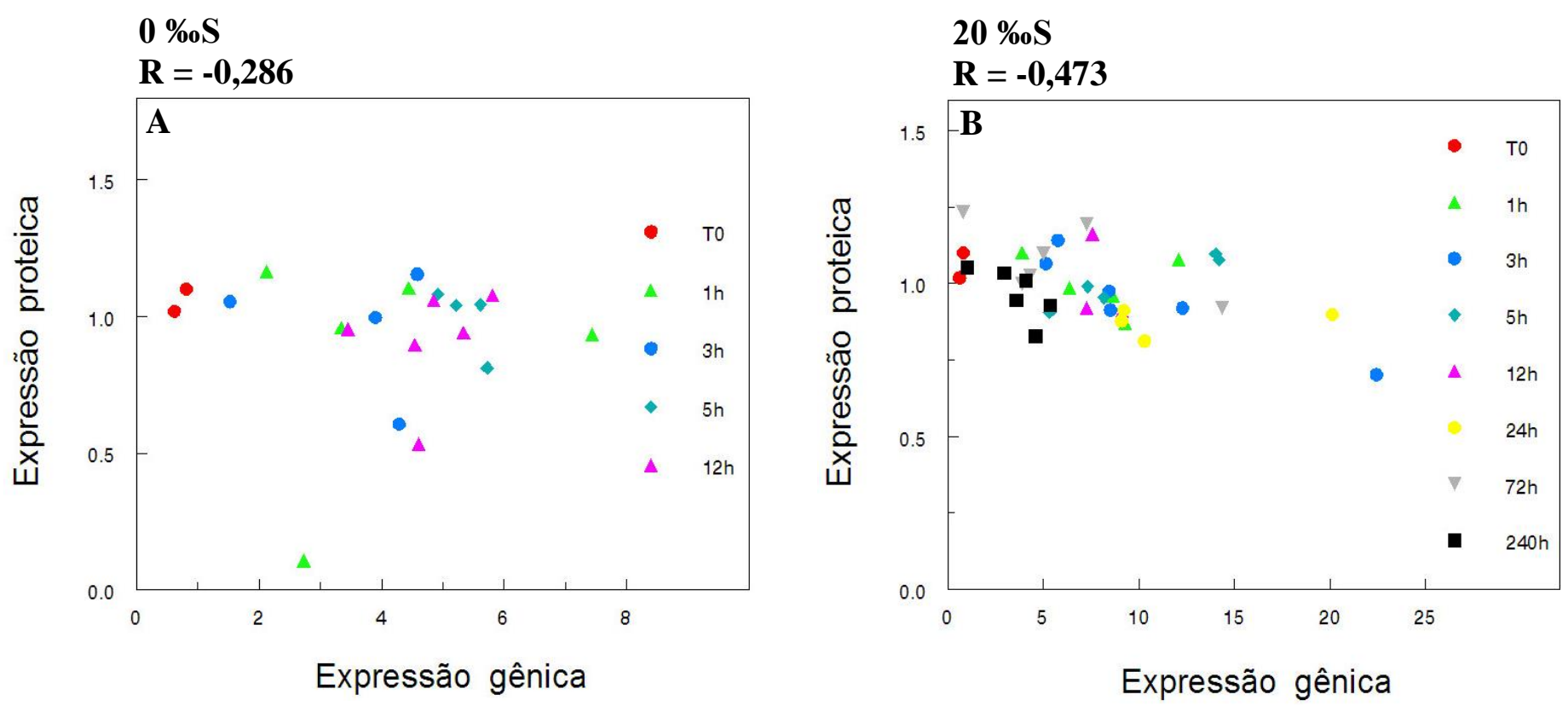

Figura 42. Correlações de Pearson entre as expressões gênica e proteica do simportador $\mathrm{Na}^{+} / \mathrm{K}^{+} / 2 \mathrm{Cl}^{-}$em brânquias do camarão de água doce Macrobrachium jelskii. A) Dados das expressões em brânquias de camarões submetidos ao decurso temporal em água destilada $(0 \% \mathrm{~S})(\mathrm{R}=-0,286)$. B) Dados das expressões em brânquias de camarões submetidos ao decurso temporal na salinidade de $20 \% \mathrm{~S}(\mathrm{R}=-0,473)$.

\subsection{Incluindo o fator espécie (Dilocarcinus pagei e Macrobrachium jelskii) nas análises estatísticas}

\section{$\underline{\text { 4.3.1 Osmolalidade }}$}

Após realizar a ANOVA de 3 fatores visando a inclusão de espécie como um fator estatístico, vimos que os valores de osmolalidade apresentam distribuição normal e são significativamente afetados pela salinidade de experimentação $(\mathrm{P}<0,001)$, tempo de exposição $(\mathrm{P}<0,001)$ e espécie estudada $(\mathrm{P}=0,019)$. As interações entre os efeitos principais também são todas significativas, com o efeito do tempo de exposição aparecendo em função da salinidade ( $\mathrm{P}<0,001)$, o efeito de espécie em função da salinidade ( $\mathrm{P}=0,004)$, o efeito da espécie em função do tempo $(\mathrm{P}<0,001)$ e o efeito de espécie em função do tempo e da salinidade $(\mathrm{P}=0,007)$.

\subsection{2[ [Cl-]}

A ANOVA de 3 fatores com os valores de $\left[\mathrm{Cl}^{-}\right]$apresentam distribuição normal e são significativamente afetados pela salinidade de experimentação $(\mathrm{P}<0,001)$, tempo de 
exposição ( $\mathrm{P}<0,001)$ e espécie estudada $(\mathrm{P}<0,001)$. As interações entre os efeitos principais também são todas significativas, com o efeito do tempo de exposição aparecendo em função da salinidade $(\mathrm{P}<0,001)$, o efeito de espécie aparece em função da salinidade $(\mathrm{P}=0,008)$, o efeito da espécie também aparece em função do tempo $(\mathrm{P}=0,003)$ e, por fim, o efeito do fator espécie aparece em função do tempo e da salinidade $(\mathrm{P}<0,001)$.

\subsection{3 $\left[\mathrm{Na}^{+}\right]$}

A ANOVA de 3 fatores com os valores de $\left[\mathrm{Na}^{+}\right]$transformados pela função raiz quadrada apresentaram distribuição normal e são significativamente afetados pela salinidade de experimentação $(\mathrm{P}<0,001)$ e espécie estudada $(\mathrm{P}<0,001)$, mas não são afetados pelo fator tempo de exposição $(\mathrm{P}=0,393)$. Algumas interações entre os efeitos principais também são significativas, com o efeito do tempo de exposição aparecendo em função da salinidade (P $<0,001)$ e o efeito de espécie aparecendo em função da salinidade $(\mathrm{P}<0,001)$.

\subsubsection{Expressão gênica da subunidade B da V(H+)-ATPase}

A ANOVA de 3 fatores com os valores da expressão gênica da subunidade $B$ da $\mathrm{V}\left(\mathrm{H}^{+}\right)$ATPase apresentaram distribuição normal. A expressão se mostrou significativamente afetada pelo tempo de exposição $(\mathrm{P}=0,038)$ e espécie estudada $(\mathrm{P}<0,001)$, mas não é afetada pelo fator salinidade $(\mathrm{P}=0,125)$. Algumas interações entre os efeitos principais também são significativas, com o efeito de espécie aparecendo em função da salinidade $(\mathrm{P}<0,001)$, o efeito da espécie aparece em função do tempo $(\mathrm{P}<0,001)$ e o efeito de espécie aparece em função do tempo e da salinidade $(\mathrm{P}=0,011)$.

\subsubsection{Expressão gênica da subunidade $\alpha$ da $\mathrm{Na}^{+} / \mathrm{K}^{+}$-ATPase}

A ANOVA de 3 fatores com os valores da expressão gênica da subunidade $\alpha$ da $\mathrm{Na}^{+} / \mathrm{K}^{+}$-ATPase não apresentam distribuição normal, porém como o valor não foi tão menor que o limite e para efeitos de discussão, consideraremos a distribuição como normal. A expressão se mostrou significativamente afetada pela espécie estudada $(\mathrm{P}<0,001)$, mas não pelos fatores salinidade $(\mathrm{P}=0,486)$ e tempo de exposição $(\mathrm{P}=0,785)$. As interações entre os efeitos principais também são todas significativas, com o efeito do tempo de exposição aparecendo em função da salinidade $(\mathrm{P}=0,005)$, o efeito de espécie aparece em função da salinidade $(\mathrm{P}<0,001)$, o efeito da espécie também aparece em função do tempo $(\mathrm{P}<0,001)$ e, por fim, o efeito de espécie aparece em função do tempo e da salinidade $(\mathrm{P}=0,049)$. 


\subsubsection{Expressão gênica do simportador $\mathrm{Na}^{+} / \mathrm{K}^{+} / 2 \mathrm{Cl}^{-}$}

A ANOVA de 3 fatores com os valores da expressão gênica do simportador $\mathrm{Na}^{+} / \mathrm{K}^{+} / 2 \mathrm{Cl}^{-}$ apresentam distribuição normal. A expressão se mostrou significativamente afetada pelo tempo de exposição $(\mathrm{P}<0,001)$ e espécie estudada $(\mathrm{P}<0,001)$, mas não é afetada pelo fator salinidade $(\mathrm{P}=0,445)$. Algumas interações entre os efeitos principais também são significativas, com o efeito de espécie aparecendo em função da salinidade $(\mathrm{P}<0,001)$, o efeito da espécie aparece em função do tempo $(\mathrm{P}<0,001)$ e o efeito de espécie também aparece em função do tempo e da salinidade $(\mathrm{P}=0,049)$.

Quando olhamos para os resultados obtidos com essas análises de 3-fatores, observamos diferenças significativas entre as espécies aqui abordadas, sendo que na maioria dos casos o efeito do fator espécie aparece em função da salinidade, do tempo de exposição ou de ambos. 
Discussão 


\section{Discussão}

Os crustáceos são um grupo notavelmente bem-sucedido em termos de biomassa e diversidade (Harris \& Aladin, 1997). A história evolutiva dos crustáceos compreende uma ampla irradiação adaptativa a partir do ambiente marinho, tendo a ocupação de nichos osmoticamente variados como resultado da diversidade de mecanismos de regulação anisosmótica extracelular e isosmótica intracelular, que constituem estratégias diferentes para manutenção da homeostase osmótica (Lockwood, 1962; Lockwood \& Inman, 1973; Mantel \& Farmer, 1983; Péqueux, 1995; Freire et al., 2008a; Evans, 2009, Charmantier et al., 2009).

Muito do sucesso dos crustáceos na colonização de diferentes habitats se deve à capacidade de tolerância, reprodução e desenvolvimnto em águas de diferentes concentrações e composições iônicas. Os diferentes táxons dos crustáceos possuem mecanismos osmorregulatórios que mantêm suas concentrações osmóticas, não apenas nos meios hipoosmóticos e hiper-osmóticos aos seus fluidos internos, mas também em salinidades que variam rapidamente, como em estuários. Diferentes estratégias osmorreguladoras surgiram como resultado da seleção natural e mesmo dentro de um único gênero existem amplas diferenças que estão continuamente sujeitas a pressões seletivas (Harris \& Aladin, 1997).

Nesse contexto, a invasão de ambientes diluídos se sustenta possivelmente no surgimento de eficientes mecanismos de hiperregulação iônica, como a atividade e expressão de um conjunto de transportadores de membrana presentes nas células ionotransportadoras especializadas do epitélio branquial (Péqueux, 1995; Kirschner, 2004; Freire et al., 2008a; McNamara \& Faria, 2012), e a redução da permeabilidade tegumentar, ambos manifestados nos elevados gradientes osmóticos e iônicos exibidos pelos crustáceos em água doce (Péqueux, 1995).

Sendo assim, os padrões osmorregulatórios que contribuíram para o sucesso da ocupação de água doce pelo caranguejo Dilocarcinus pagei e pelo camarão Macrobrachium jelskii foram investigados nesse estudo.

\subsection{Osmorregulação em Dilocarcinus pagei e Macrobrachium jelskii: do sistêmico ao $\underline{\text { molecular }}$}

\subsubsection{Dilocarcinus pagei}

Em Dilocarcinus pagei, um caranguejo hololimnético de água doce continental, foram registrados valores médios de $313 \pm 22 \mathrm{mOsm} \mathrm{kg}^{-1} \mathrm{H}_{2} \mathrm{O}$ para osmolalidade, $157 \pm 13 \mathrm{mmol} \mathrm{L}-$ 
${ }^{1}$ para $\left[\mathrm{Cl}^{-}\right]$e $143 \pm 20 \mathrm{mmol} \mathrm{L}-1$ para $\left[\mathrm{Na}^{+}\right]$, na hemolinfa dos caranguejos quando em seu meio natural, água doce. Esses valores são semelhantes aos encontrados por Augusto et. al (2007b) e Onken \& McNamara (2002), onde os valores registrados foram de $420 \pm 39$ e $386 \pm$ $18 \mathrm{mOsm} \mathrm{kg}{ }^{-1} \mathrm{H}_{2} \mathrm{O}$ para osmolalidade, $226 \pm 13$ e $206 \pm 12 \mathrm{mmol} \mathrm{L}^{-1}$ para $\left[\mathrm{Cl}^{-}\right], 214 \pm 20 \mathrm{e}$ $190 \pm 13 \mathrm{mmol} \mathrm{L}^{-1}$ para $\left[\mathrm{Na}^{+}\right]$, respectivamente.

Em nossos animais experimentais do grupo controle, a proporção da $\left[\mathrm{Cl}^{-}\right]$pela osmolalidade foi de 0,50 e a razão da $\left[\mathrm{Na}^{+}\right]$pela osmolalidade foi de 0,46 , logo, se somadas as proporções, o resultado é praticamente 1. De acordo com os dados de Augusto et. al (2007b) e Onken \& McNamara (2002), essas razões são de 0,54 e 0,53 ([Cl- $]$ /osmolalidade) e 0,51 e $0,49\left(\left[\mathrm{Na}^{+}\right] /\right.$osmolalidade), respectivamente. Dessa forma, as $\left[\mathrm{Cl}^{-}\right]$e $\left[\mathrm{Na}^{+}\right]$, determinam praticamente $100 \%$ dos valores encontrados para a osmolalidade da hemolinfa, sugerindo ausência de componente orgânico (aminoácidos livres) na hemolinfa. Tal fato evidencia a atuação da RAE (Regulação Anisosmótica Extracelular) na manutenção da osmolalidade, concentração iônica e volume da hemolinfa em $D$. pagei, graças à atividade das proteínas ionotransportadoras $\mathrm{Na}^{+} / \mathrm{K}^{+}$-ATPase, $\mathrm{V}\left(\mathrm{H}^{+}\right)$-ATPase, do simportador $\mathrm{Na}^{+} / \mathrm{K}^{+} / 2 \mathrm{Cl}^{-}$e de canais iônicos.

O decurso temporal de D. pagei a meio hiperosmótico subletal $(25 \% \mathrm{~S})$ demonstrou que a osmolalidade, $\left[\mathrm{Cl}^{-}\right]$e $\left[\mathrm{Na}^{+}\right]$da hemolinfa aumentaram gradualmente ao longo de 10 dias, atingindo valores máximos de $789 \mathrm{mOsm} \mathrm{kg}^{-1} \mathrm{H}_{2} \mathrm{O}$ (aumento de 2,52 vezes), $400 \mathrm{mmol} \mathrm{\textrm {L } ^ { - 1 }}$ (2,54 vezes) e $312 \mathrm{mmol} \mathrm{L}^{-1}$ (2,18 vezes), respectivamente. Verificamos que, em tempos mais tardios do decurso temporal, a hemolinfa se tornou isosmótica (757 mOsm $\mathrm{kg}^{-1} \mathrm{H}_{2} \mathrm{O}$ ), isoclorêmica $\left(395 \mathrm{mmol} \mathrm{L}^{-1}\right)$ e isonatriurêmica $\left(304 \mathrm{mmol} \mathrm{L}^{-1}\right)$. Esses resultados corroboram os de Augusto et al. (2007b), que demonstraram a capacidade de D. pagei hiperregular até o ponto isosmótico de $744 \mathrm{mOsm} \mathrm{kg}{ }^{-1} \mathrm{H}_{2} \mathrm{O}(=24 \% \mathrm{~S})$. Ainda, esses autores verificaram que em 48 horas de exposição em água a $25 \% \mathrm{~S}$, a [ $\left.\mathrm{Cl}^{-}\right]$foi de $351 \pm 13 \mathrm{mmol} \mathrm{L}^{-1}$, bem semelhante aos nossos achados. A $\left[\mathrm{Na}^{+}\right]$, por sua vez, foi de $274 \pm 36 \mathrm{mmol} \mathrm{L}-1$, coerente com o aumento da osmolalidade.

Em água a $0 \% \mathrm{~S}$, a $\left[\mathrm{Na}^{+}\right]$na hemolinfa dos caranguejos diminuiu a partir de 24 horas de exposição, nesse tempo atingindo o valor mínimo de $21 \mathrm{mmol} \mathrm{L}^{-1}$. Esse resultado condiz com o conjunto de dados, pois a exposição a esse desafio hiposmótico severo por períodos elevados leva à perda por difusão pelas brânquias, membranas artrodiais e pela urina isosmótica à hemolinfa. Mas a osmolalidade e a $\left[\mathrm{Cl}^{-}\right]$da hemolinfa não apresentaram diminuições significativas ao longo do decurso temporal, revelando o elevado poder hiperregulador de $D$. pagei. Há de se considerar que a água destilada foi constantemente trocada ao 
longo do decurso temporal e, portanto, os caranguejos não poderiam reciclar os íons perdidos pela hemolinfa e urina. Esses resultados são inéditos, pois são poucos os crustáceos que sobrevivem e osmorregulam em água destilada (0\%oS) descritos na literatura (Riegel, 1959).

Dilocarcinus pagei está muito bem adaptado à água doce, e não enfrenta variações relevantes na salinidade do meio externo, sendo a osmolalidade da sua hemolinfa menor, em comparação a caranguejos do entre-marés ou estuarinos (Thurman, 2003; Van Horn \& Tolley, 2009; Faria et al., 2017). Consequentemente, dado essa diminuição dos gradientes osmótico e iônico e a redução no gasto energético para captação de sal (Onken \& McNamara, 2002), as respostas obtidas revelam a capacidade de ajuste osmorregulatório em meio extremamente diluído, além daquela que ocorre em seu habitat natural.

A manutenção da estabilidade iônica da hemolinfa reflete a capacidade osmorregulatória, frente às mudanças de salinidade ocorridas no ambiente. Seu conhecimento pode trazer informações importantes a respeito da ocupação e permanência de determinadas espécies em ambientes osmoticamente variados, inclusive em água doce (Mantel \& Farmer, 1983; Péqueux, 1995). Notou-se uma clara assimetria na capacidade regulatória tal que o desafio hiperosmótico de $25 \% \mathrm{~S}$ levou à isosmoticidade, revelando a inabilidade de secreção de sal comparado à habilidade de captação de sal em D. pagei.

Embora os caranguejos tenham sobrevivido ao decurso temporal de 10 dias em água destilada, o que representa um desafio hiposmótico severo, a $\mathrm{V}\left(\mathrm{H}^{+}\right)$-ATPase, proteína ionotransportadora com marcante papel na captação ativa de íons em decápodes tolerantes à água doce (Onken \& Riestenpatt, 1998; Weihrauch et al., 2004; Freire et al., 2008a; Faleiros et al., 2010), apenas apresentou uma tendência de aumento na expressão do seu mRNA nos tempos iniciais do decurso temporal, com restabelecimento dos valores iniciais em 24 horas. A $\mathrm{V}\left(\mathrm{H}^{+}\right)$-ATPase é peça chave no processo de hiper-regulação e apesar de não haver variação significativa na expressão do mRNA desse gene, não houve diminuição na osmolalidade e na $\left[\mathrm{Cl}^{-}\right]$da hemolinfa, mais uma vez refletindo o elevado poder hiper-regulador de D. pagei.Nos caranguejos submetidos à exposição em água a $25 \% \mathrm{~S}$, houve diminuição na expressão de mRNA para a $\mathrm{V}\left(\mathrm{H}^{+}\right)$-ATPase desde os tempos iniciais do decurso temporal, que se manteve até o tempo de 240 horas. Tal fato sugere a não participação da $\mathrm{V}\left(\mathrm{H}^{+}\right)$-ATPase no ajuste osmorregulatório em meios mais concentrados. Esses dados corroboram os de Firmino et al. (2011), que verificaram rápida redução na atividade fosfohidrolítica da $\mathrm{V}\left(\mathrm{H}^{+}\right)$-ATPase nas brânquias posteriores de D. pagei, após 1 hora de exposição à água 21 \%oS (2011). Este é um componente importante no ajuste osmorregulatório em salinidades elevadas, pois rapidamente diminui a captação iônica ativa, particularmente de $\mathrm{Na}^{+}$. 
Houve diminuição significativa de expressão de mRNA da $\mathrm{Na}^{+} \mathrm{K}^{+}$-ATPase, tanto em água destilada $(0 \% \mathrm{~S})$, quanto em água a $25 \% \mathrm{~S}$. Em água destilada a diminuição se deu a partir de 24 horas, o que condiz com a queda na $\left[\mathrm{Na}^{+}\right]$da hemolinfa a partir desse mesmo tempo, uma vez que é a $\mathrm{Na}^{+} \mathrm{K}^{+}$-ATPase que transporta esse íon para a hemolinfa. Em água salobra a diminuição aconteceu desde os tempos iniciais da experimentação (1 hora), o que também sugere a não participação da $\mathrm{Na}^{+} \mathrm{K}^{+}$-ATPase em meios hiperosmóticos. Interessantemente, a maior média dos valores de expressão do mRNA da $\mathrm{Na}^{+} \mathrm{K}^{+}$-ATPase registrada em água destilada se deu no tempo de 12 horas $(1,035)$. Em água a $25 \%$, a menor média dos valores de expressão também se deu nesse tempo $(0,21)$. Talvez 12 horas seja o tempo de modulação da expressão gênica. Sabe-se que em desafio salino, os mecanismos anisosmóticos agem de maneira rápida, por modulação da atividade de enzimas ionotransportadoras (Corotto \& Holliday, 1996), tais como a $\mathrm{Na}^{+} \mathrm{K}^{+}$-ATPase e a $\mathrm{V}^{+} \mathrm{H}^{+}$)ATPase, diretamente pelos íons envolvidos, ou mediado por ação hormonal (Lucu \& Towle, 2003). Ainda, a atividade enzimática pode ser modulada pela translocação das proteínas ionotransportadoras da membrana plasmática para vesículas citoplasmáticas, onde permanecem inativas (Paller, 1994; Tsai \& Lin, 2007). Em Callinectes sapidus, o aumento da atividade $\mathrm{Na}^{+} / \mathrm{K}^{+}$-ATPásica, paralelo à redução da salinidade, não é resultado do aumento da expressão de seu mRNA (Towle et al., 2001). A aclimatação à salinidade tem pouco efeito na proporção da subunidade $\alpha$ da $\mathrm{Na}^{+} / \mathrm{K}^{+}$-ATPase nas brânquias posteriores de C. sapidus (Towle et al., 2001), sugerindo estratégias diversas na regulação da atividade da $\mathrm{Na}^{+} / \mathrm{K}^{+}$ATPase, em resposta às mudanças de salinidade (Leone et al., 2005).

Com relação à expressão gênica do mRNA do simportador $\mathrm{Na}^{+} / \mathrm{K}^{+} / 2 \mathrm{Cl}^{-}$, não houve mudanças significativas na sua expressão em água destilada. Em água a $25 \%$ o , a expressão do mRNA desse transportador se mantém praticamente constante ao longo do decurso temporal, apresentando redução apenas no tempo mais tardio (240 horas). Dados de Freire et al. (2013) sugerem que, depois de um longo tempo de evolução em água doce, a capacidade de lidar com desfios hiperosmóticos diminuiu em D. pagei, enquanto a capacidade de superar desafios hiposmóticos se manteve, talvez devido à diluição da hemolinfa em água doce durante a muda. Possivelmente haja uma tendência natural para a redução, inalteração ou insensibilidade da expressão do simportador $\mathrm{Na}^{+} / \mathrm{K}^{+} / 2 \mathrm{Cl}^{-}$após a invasão da água doce, já que esse transportador leva ao aumento do volume, fato indesejado em meios diluídos. Isso é compatível com a ideia da ausência dessa proteína, conforme sugerido no modelo das brânquias de D. pagei em McNamara \& Faria (2012 - Figura 4) (Freire et al., 2013). Como 
demonstrado anteriormente, D. pagei não hiporregula $\mathrm{Cl}^{-}$e $\mathrm{Na}^{+}$, sendo que a ausência de alteração na expressão do simportador $\mathrm{Na}^{+} / \mathrm{K}^{+} / 2 \mathrm{Cl}^{-}$reflete ou mesmo subsidia tal fato.

\subsubsection{Macrobrachium jelskii}

Como já mencionado, as espécies são melhor adaptadas a certas condições ambientais, as quais constituem a faixa ótima de determinados parâmetros onde suas capacidades fisiológicas e ecológicas são mais eficientes (Begon et al., 2007). Para comparação interespecífica das habilidades osmorregulatórias é necessário conhecer a faixa de tolerância de cada espécie à salinidade. Uma medida comumente utilizada para teste dos limites de tolerância à salinidade corresponde ao valor do limite superior da salinidade que é letal a 50\% dos indivíduos durante um período arbitrário de exposição (LSS 50 - Thurman, 2002; 2003; Kefford et al., 2004). Assim, temos uma referência de que o desafio salino experimentalmente estabelecido seja correspondente e comparável entre as diferentes espécies. Tal medida também possibilita testar se há correlação entre a salinidade em que as espécies são encontradas em seus respectivos habitats e o valor obtido da $\mathrm{LSS}_{50}$ (Kefford et al., 2004).

De acordo com Augusto et al. (2007b), a salinidade hiper-osmótica experimental de 25 $\%_{0} \mathrm{~S}$ corresponde a $87 \%$ da $\mathrm{LSS}_{50}$ para Dilocarcinus pagei. Como estes autores obtiveram dados interessantes, mantivemos a salinidade de $25 \%$ como desafio hiper-osmótico para a espécie. No entanto, para Macrobrachium jelskii estabelecemos experimentalmente esse desafio em $80 \%$ da $\mathrm{LSS}_{50}$, uma vez que esse é o valor geralmente utilizado em nosso laboratório, por constituir um desafio hiperosmótico considerável em uma faixa de tolerância subletal. Esse parâmetro foi cuidadosamente pensado, uma vez que o objetivo desse estudo é comparar as respostas fisiológicas e moleculares frente a desafios osmóticos nessas duas espécies de água doce, evolutivamente distantes e, principalmente, testar a nossa hipótese em um desafio subletal para ambas.

Com as curvas de sobrevivência apresentadas na Figura 32, verificamos que a salinidade hiperosmótica experimental de $20 \%$ corresponde a $80 \%$ da $\mathrm{LSS}_{50}$ para Macrobrachium jelskii. Sendo essa espécie hololimnética, assim como o caranguejo D. pagei, esperava-se, de fato, que o valor desse parâmetro fosse próximo entre as duas espécies. Assim, tendo estabelecido o desafio, realizamos o decurso temporal hipo-osmótico $(0 \% \mathrm{OS})$ e hiperosmótico $(20 \% \mathrm{~S})$, com espécimes de M. jelskii.

Foram registrados valores médios de $390 \pm 10,59 \mathrm{mOsm} \mathrm{kg}^{-1} \mathrm{H}_{2} \mathrm{O}$ para osmolalidade, $173 \pm 6,13 \mathrm{mmol} \mathrm{L} \mathrm{L}^{-1}$ para $\left[\mathrm{Cl}^{-}\right]$e $173 \pm 10,99 \mathrm{mmol} \mathrm{L}-1$ para $\left[\mathrm{Na}^{+}\right]$, na hemolinfa dos camarões quando em seu meio natural, água doce. Esses dados estão próximos aos 
encontrados por Faria et al. (2011), onde os valores registrados para outra espécie hololimnética do gênero, Macrobrachium brasiliensis, foram de 404,2 $\pm 1,3 \mathrm{mOsm} \mathrm{kg}^{-1} \mathrm{H}_{2} \mathrm{O}$ para osmolalidade e 176,6 $\pm 8,5 \mathrm{mmol} \mathrm{L}^{-1}$ para $\left[\mathrm{Cl}^{-}\right]$. Macrobrachium potiuna, espécie também hololimnética, apresentou o valor de 436,5 $\pm 1,9 \mathrm{mOsm} \mathrm{kg}{ }^{-1} \mathrm{H}_{2} \mathrm{O}$ para a osmolalidade da hemolinfa em meio natural, e $\left[\mathrm{Cl}^{-}\right]$de $166 \pm 11,5 \mathrm{mM}$ (Maraschi, 2018). Os dados de $\left[\mathrm{Na}^{+}\right]$não foram registrados.

A exposição de $M$. jelskii a meio hiperosmótico subletal $(20 \% \mathrm{~S})$ demonstra que a osmolalidade, a $\left[\mathrm{Cl}^{-}\right]$e a $\left[\mathrm{Na}^{+}\right]$da hemolinfa aumentam gradualmente ao longo do decurso temporal de 10 dias, atingindo valores máximos de $569 \mathrm{mOsm}^{-1} \mathrm{~kg} \mathrm{H}_{2} \mathrm{O}, 259 \mathrm{mmol} \mathrm{L}^{-1}$ e 268 mmol $\mathrm{L}^{-1}$, respectivamente. Verificamos que, a partir de 24 horas, a hemolinfa estava próxima, porém abaixo do ponto isosmótico $\left(600 \mathrm{mOsm} \mathrm{kg}^{-1} \mathrm{H}_{2} \mathrm{O}\right)$ e isonatriurêmico (280 mmol L ${ }^{-1}$ ), o que foi mantido até o tempo final de 240 horas. Os valores da $\left[\mathrm{Cl}^{-}\right]$também se mostraram próximos, embora abaixo do ponto isoclorêmico a partir de 72 horas $(320 \mathrm{mmol} \mathrm{L}$ ${ }^{1}$ ), revelando o maior poder hiporregulador de $M$. jelskii em comparação à D. pagei. Esses resultados corroboram os de Faria et al. (2011), que demonstraram a capacidade de $M$. brasiliensis hiperregular até o ponto isosmótico de $632 \mathrm{mOsm} \mathrm{kg}^{-1} \mathrm{H}_{2} \mathrm{O}(=21 \% \mathrm{~S})$. Ainda, esses autores verificaram que em 5 dias de exposição em água a $21 \% \mathrm{~S}$, a [ $\left.\mathrm{Cl}^{-}\right]$foi de 302,6 \pm $10 \mathrm{mmol} \mathrm{L}^{-1}$, bem semelhante aos nossos achados. Embora os estudos não tenham sido feitos com a mesma espécie de camarão do gênero Macrobrachium, sabe-se que ambas são hololimnéticas, vivem em ambientes semelhantes e possuem a mesma estrutura branquial.

Em água destilada $(0 \% \mathrm{~S})$, os espécimes de camarões sobreviveram apenas até pouco mais de 12 horas, sendo que nenhum atingiu o período de 24 horas. Em 12 horas, a osmolalidade apresentou valores mínimos $\left(299 \pm 19,46\right.$ mOsm kg $\left.{ }^{-1} \mathrm{H}_{2} \mathrm{O}\right)$, bem como a $\left[\mathrm{Cl}^{-}\right]$ $\left(107 \pm 8,87 \mathrm{mmol} \mathrm{L}^{-1}\right)$ e a $\left[\mathrm{Na}^{+}\right]\left(119 \pm 7,31 \mathrm{mmol} \mathrm{L}^{-1}\right)$. A água destilada foi constantemente trocada ao longo do decurso temporal, impossibilitando a reciclagem os íons perdidos pela hemolinfa.

Embora os valores mínimos de osmolalidade e da $\left[\mathrm{Cl}^{-}\right]$de D. pagei em água destilada sejam semelhantes $\left(255 \mathrm{mOsm} \mathrm{kg}{ }^{-1} \mathrm{H}_{2} \mathrm{O}\right.$ e $119 \mathrm{mmol} \mathrm{L}^{-1}$, respectivamente, em 72 horas de exposição) aos de $M$. jelskii, e os valores mínimos da $\left[\mathrm{Na}^{+}\right]$tenham sido bem menores (21 mmol $\mathrm{L}^{-1}$ ), os caranguejos sobreviveram até o final do decurso temporal que estipulamos como 240 horas. Dessa forma, verificamos como essas espécies reagem ao desafio em água destilada de forma bastante diferente, apesar de ambas serem bem adaptadas ao desafio hiperosmótico em ambiente dulcícola. Como já relatado, esses resultados são inéditos. 
Sabe-se que a relação superfície/volume afeta diretamente a maioria dos processos fisiológicos (Willmer et al., 2005) e pode ser um dos fatores para a mortalidade dos camarões em água destilada. Uma vez que os processos osmorregulatórios são influenciados diretamente por essa relação (Randall et al., 1997), podemos constatar, pelo tamanho, morfologia e grau de carcinizaçao que $M$. jelskii é mais suscetível aos efeitos da troca de água e íons com o meio ambiente, quando comparado à D. pagei. Inclusive, esse efeito pode ser de intensidade variável quando consideramos a área superficial branquial e taxa de ventilação branquial, mas esses parâmetros não foram avaliados nesse estudo.

Além disso, no grupo dos caranguejos, a morfologia corporal está encurtada devido ao dobramento ventral do abdômen por baixo da parte anterior do corpo. Dessa forma, o abdômen está consideravelmente reduzido e se encaixa debaixo do cefalotórax, reduzindo a área de troca com o meio externo e, consequentemente, o influxo de água (Barnes, 1990, Schimidt-Nielsen, 2002) e a perda de íons. Já as lagostas e os camarões possuem um grande abdômen estendido. O corpo dos carídeos tende a ser cilíndrico e lateralmente comprimido, com um abdômen bem desenvolvido e exoesqueleto comumente fino e flexível. Portanto, caranguejos que invadiram a água doce há menos tempo que algumas espécies de camarões podem possuir uma maior capacidade de sobreviver em ambientes mais concentrados e/ou mais diluídos (Augusto, 2005).

Houve aumentos significativos na expressão do mRNA da subunidade B da enzima $\mathrm{V}\left(\mathrm{H}^{+}\right)$-ATPase desde o início da exposição à água destilada até o período de 12 horas, após o qual os camarões não sobreviveram. Tal fato revela um menor poder hiper-regulador em $M$. jelskii, em comparação à D. pagei. É muito bem descrito o papel marcante da $\mathrm{V}\left(\mathrm{H}^{+}\right)$-ATPase na captação ativa de íons em decápodes tolerantes à água doce (Onken \& Riestenpatt, 1998; Weihrauch et al., 2004; Freire et al., 2008a; Faleiros et al., 2010), sendo essa proteína considerada a força motriz na captação de sal. Nos camarões submetidos à exposição em água a $20 \% \mathrm{~S}$, também houve aumento na expressão de mRNA para a $\mathrm{V}\left(\mathrm{H}^{+}\right)$-ATPase de 3 a 12 horas de exposição, mas que não se manteve nos tempos posteriores, mais tardios. Embora alguns estudos sugiram a não participação da $\mathrm{V}\left(\mathrm{H}^{+}\right)$-ATPase no mecanismo de secreção de sal (Faleiros et al., 2010; Firmino et al., 2011), curiosamente Luquet et al. (2005) demonstraram que em Neohelice granulata, um caranguejo da região entre-marés, a expressão da subunidade B da $\mathrm{V}\left(\mathrm{H}^{+}\right)$-ATPase também é aumentada em meios com salinidade elevada. Outros trabalhos mostram que a secreção ativa de $\mathrm{Na}^{+}$do citosol em plantas é tipicamente carreada por transportadores proteicos transmembrana, como antiportadores $\mathrm{Na}^{+} / \mathrm{H}^{+}$(Shi \& Zhu, 2002, Xue et al., 2004, Yang et al., 2009, Oh et al., 2010), que são dependentes do 
gradiente eletroquímico criado pela $\mathrm{V}\left(\mathrm{H}^{+}\right)$-ATPase da membrana plasmática e vacuolar (Rea \& Poole 1985, 1993, Chen et al., 2007, Silva et al., 2010). Ainda, sabe-se que a $\mathrm{V}\left(\mathrm{H}^{+}\right)$ATPase também está envolvida em outras funções, como na excreção de amônia pelas brânquias (Weihrauch et al., 2002, 2004), que é, ao menos em parte, independente da salinidade do meio.

Os resultados de expressão gênica da $\mathrm{V}\left(\mathrm{H}^{+}\right)$-ATPase encontrados em $M$. jelskii são um pouco diferentes aos encontrados em $D$. pagei, pois nos caranguejos expostos à água destilada $(0 \% \mathrm{O})$ não houve variações significativas na expressão do mRNA da subunidade B da enzima $\mathrm{V}\left(\mathrm{H}^{+}\right)$-ATPase. Além disso, nos caranguejos submetidos à exposição em água a 25 \%oS, houve diminuição na expressão de mRNA para a $\mathrm{V}\left(\mathrm{H}^{+}\right)$-ATPase desde os tempos iniciais do decurso temporal, que se manteve até o tempo de 240 horas, o que sugere a não participação da $\mathrm{V}\left(\mathrm{H}^{+}\right)$-ATPase no mecanismo de secreção de sal em D. pagei.

Com relação à expressão de $\mathrm{Na}^{+} \mathrm{K}^{+}$-ATPase em $M$. jelskii, houve tendência de aumento na expressão do mRNA da subunidade $\alpha$ em água destilada, sobretudo no tempo de 12 horas. Nos camarões submetidos à exposição em água a $20 \% \mathrm{~S}$, houve aumento significativo na expressão de mRNA para a $\mathrm{Na}^{+} \mathrm{K}^{+}$-ATPase até o período de 5 horas de exposição, mas que não se manteve nos tempos posteriores, principalmente nos tempos mais tardios $(72$ e 240 horas). Muitos estudos demostraram que a $\mathrm{Na}^{+} \mathrm{K}^{+}$-ATPase localizada na porção basal dos ionócitos do epitélio branquial dirige a captura de $\mathrm{Na}^{+}$ativamente do meio diluído para a hemolinfa em caranguejos hiperreguladores (Péqueux, 1995; Zare \& Greenaway, 1998; Lucu \& Towle, 2003), e essa mesma proteína participa da secreção de $\mathrm{Na}^{+}$para o meio em crustáceos hiporreguladores (Martinez et al., 1998), como mostram os modelos ilustrados nas Figuras 2 e 3. Dessa forma, transportando para a ultra-estrutura de M. jelskii, isso explicaria a tendência de aumento na expressão gênica dessa proteína em ambos os desafios osmóticos. Os resultados de expressão gênica da $\mathrm{Na}^{+} \mathrm{K}^{+}$-ATPase encontrados em $M$. jelskii se contrapõem aos encontrados em $D$. pagei, pois no caranguejo houve diminuição significativa de expressão de mRNA da $\mathrm{Na}^{+} \mathrm{K}^{+}$-ATPase, tanto em água destilada $(0 \% \mathrm{~S})$, quanto em água a $25 \% \mathrm{~S}$.

Já a expressão gênica do mRNA do simportador $\mathrm{Na}^{+} / \mathrm{K}^{+} / 2 \mathrm{Cl}^{-}$aumentou consideravelmente em ambos os desafios osmóticos realizados com os camarões. Em $M$. jelskii expostos à água a $20 \% \mathrm{~S}$, a expressão do mRNA desse transportador se elevou para até aproximadamente 10 a 14 vezes em relação ao grupo controle, sobretudo nos tempos de 3 e 12 horas. Em água a $0 \% \mathrm{~S}$ também houve elevação da expressão desde o início da experimentação, atingindo níveis de expressão de 5 a 6 vezes maior que os resultados 
encontrados no grupo controle. Estudos de clonagem molecular mostraram a expressão do simportador $\mathrm{Na}^{+} / \mathrm{K}^{+} / 2 \mathrm{Cl}^{-}$em Neohelice granulata e sugeriram que a secreção de sal está associada ao aumento da atividade da $\mathrm{Na}^{+} / \mathrm{K}^{+}$-ATPase durante a exposição em salinidade hiperosmótica (45\% S) (Luquet et al., 2005). Dessa forma, embora a $\mathrm{Na}^{+} / \mathrm{K}^{+}$-ATPase seja essencial em ambas as regulações hiper- e hipo-iônica, não é ela que define a direção do transporte, mas sim o simportador $\mathrm{Na}^{+} / \mathrm{K}^{+} / 2 \mathrm{Cl}^{-}$que pode se posicionar em regiões distintas nas células epiteliais que transportam sal em vertebrados: apicalmente, promovendo a captação de sal, e basolateralmente, promovendo a secreção (Mount et al., 1998). Tal fato é mais uma vez confirmado pelo aumento da expressão do simportador $\mathrm{Na}^{+} / \mathrm{K}^{+} / 2 \mathrm{Cl}^{-}$em $M$. jelskii, quando em água a 0 ou $20 \%$ S. Novamente, os dados encontrados em M. jelskii são bastantes divergentes aos encontrados em D. pagei. A expressão gênica do mRNA do simportador $\mathrm{Na}^{+} / \mathrm{K}^{+} / 2 \mathrm{Cl}^{-}$não teve mudanças significativas em espécimes do braquiúro expostos à água destilada ou a $25 \% \mathrm{~S}$.

\subsection{Análise geral de expressão proteica e sua correlacão com a expressão gênica}

A expressão da proteína $\mathrm{Na}^{+} \mathrm{K}^{+}$-ATPase não apresentou diferenças significativas ao longo do decurso temporal de D. pagei e M. jelskii, independente do tipo de desafio osmótico. Também não apresentou correlação forte com a expressão gênica desse mesmo ionotransportador (Figuras 28 e 37).

Interessantemente, observamos uma tendência de aumento da expressão proteica de $\mathrm{Na}^{+} \mathrm{K}^{+}$-ATPase no tempo de $3 \mathrm{~h}$ em água salobra, para ambas as espécies. O contrário é observado em água destilada, também no tempo de 3 horas para as duas espécies. Ainda, de forma nítida, podemos notar como o perfil ao longo do decurso temporal em água destilada (0 $\left.\%_{0} \mathrm{~S}\right)$ parece ser oposto ao perfil do decurso em água a $25 \% \mathrm{~S}$, quando da experimentação com D. pagei (Figuras 43A e B). Quando olhamos para o decurso temporal da expressão gênica da $\mathrm{Na}^{+} \mathrm{K}^{+}$-ATPase em brânquias de D. pagei submetidos à água destilada $(0 \% \mathrm{~S}$ Figura 43A), notamos uma tendência de aumento em 12 horas. Comparando com o decurso temporal da expressão proteica na mesma condição (Figura 43A), a tendência de maior expressão é em 24 horas, sendo que esse intervalo de 12 horas poderia refletir o tempo de síntese proteica. 

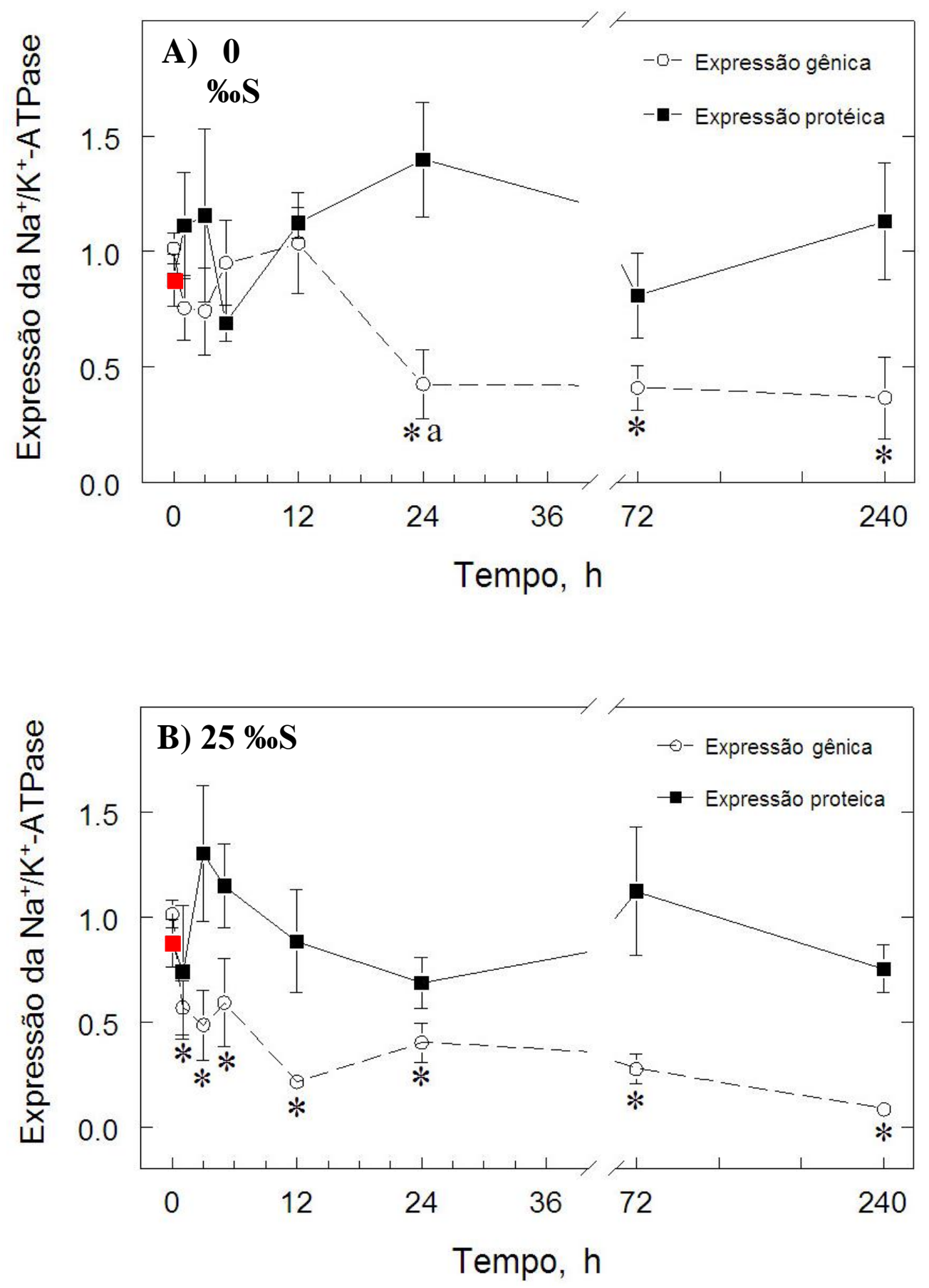

Figura 43. Decurso temporal do efeito da aclimatação às salinidades de A) 0 (água destilada) ou B) $25 \% \mathrm{~S}$ sobre as expressões gênica e proteica da subunidade $\alpha$ da $\mathrm{Na}^{+} / \mathrm{K}^{+}$-ATPase branquial de D. pagei $(\mathrm{X} \pm \mathrm{EPM}, 3 \leq$ $\mathrm{N} \leq 7)$. A análise de expressão gênica foi realizada por PCR em Tempo Real e a expressão da $\mathrm{Na}^{+} / \mathrm{K}^{+}-\mathrm{ATPase}$ foi normalizada pela expressão do gene PRL10 (constitutiva), em cada amostra. A análise de expressão proteica foi realizada por western blotting e a expressão da proteína de interesse foi normalizada pela expressão proteica da $\beta$-actina (constitutiva), em cada amostra. Os valores finais representam a relação entre esses valores obtidos para cada intervalo de tempo em 0 ou $25 \% \mathrm{~S}$ e o valor do grupo controle $(<0,5 \% \mathrm{~S}$, tempo 0$)$. *Significativamente diferente em relação ao grupo controle (representado em vermelho). 
Em relação à expressão do simportador $\mathrm{Na}^{+} / \mathrm{K}^{+} / 2 \mathrm{Cl}^{-}$em brânquias de $M$. jelskii, embora os dados de expressão gênica tenham aumentado de 3 a 5 vezes em água destilada $(0 \%$ S $)$ e de 3,5 a 12 vezes em água salobra $(20 \% \mathrm{~S})$, a expressão proteica também não apresentou variações significativas, também refletidas na correlação fraca com a expressão gênica (Figura 42).

Já discutimos que, em desafio salino, a regulação dos mecanismos anisosmóticos podem incluir a modulação da atividade de enzimas ionotransportadoras (Corotto \& Holliday, 1996), diretamente pelos íons envolvidos, ou mediado por ação hormonal (Lucu \& Towle, 2003). Proteínas ionotransportadoras também podem ser inativadas por meio de translocação da membrana plasmática para vesículas citoplasmáticas (Paller, 1994; Tsai \& Lin, 2007). Tais fatos podem explicara falta de alterações significativas da expressão proteica da $\mathrm{Na}^{+} / \mathrm{K}^{+}$ATPase e também do simportador $\mathrm{Na}^{+} / \mathrm{K}^{+} / 2 \mathrm{Cl}^{-}$ao longo do decurso temporal, além, é claro, das limitações bem conhecidas de quantificação pela técnica de western blotting.

É bem estabelecido que a abundância proteica relativa pode ou não ser proporcional aos níveis de expressão relativa de mRNA (Vogel \& Marcotte, 2012). Em células de mamíferos, mRNAs são produzidos em uma escala muito menor, quando comparada à proteica. Em média, essas células produzem duas cópias de um mRNA específico por hora, enquanto dúzias de cópias de proteína são produzidas para cada molécula de mRNA no mesmo intervalo de tempo. Ainda, mRNAs são menos estáveis que as proteínas, com meia vida de 2,6 a 7 horas versus 46 horas, respectivamente (Schwanhäusser et al., 2011; Sharova et al., 2009).

Somado a isso, é importante dizer que a marcação dos anticorpos nos géis que usamos para detecção das proteínas $\mathrm{Na}^{+} / \mathrm{K}^{+}$-ATPase e $\mathrm{Na}^{+} / \mathrm{K}^{+} / 2 \mathrm{Cl}^{-}$não é muito intensa, muitas vezes, inclusive, nem é evidente. Os níveis de background, por exemplo, em alguns casos eram mais fortes que a própria banda que julgamos ser a da proteína de interesse, principalmente no que se refere à marcação do simportador $\mathrm{Na}^{+} / \mathrm{K}^{+} / 2 \mathrm{Cl}^{-}$. Dessa forma, embora os resultados de expressão proteica sejam interessantes, eles devem ser analisados com cuidado. Já na obtenção dos dados de expressão gênica, os primers e os cDNAs passaram por validação meticulosa e os dados foram detectados por meio de uma técnica muito mais precisa, que é a expressão gênica relativa em tempo real. Assim sendo, embora a expressão gênica e a expressão proteica não nos forneçam as mesmas respostas e não tenham apresentado correlações significativas para nenhum dos genes e proteínas avaliados, há muito o que se extrair dos nossos dados de expressão gênica, mas nossos dados de expressão proteica não foram obtidos nas melhores condições analíticas. 


\subsection{Comparação entre as respostas das duas espécies: a inclusão do fator 'espécie' nas análises estatísticas}

As espécies aqui estudadas, o caranguejo D. pagei e o camarão M. jelskii, são muito remotamente relacionadas em termos evolutivos, ou seja, não há sinal filogenético, como abordaremos mais adiante (Figuras 46B e 46D, onde D. pagei aparece como grupo externo em relação aos camarões Palaemonidae).

Levando tal fato em consideração, vimos que os dados obtidos com a ANOVA de 3 fatores, incluindo tempo de exposição, salinidade e espécie, confirmam estatisticamente as diferenças de respostas entre as duas espécies, frente aos desafios hiper- e hipo-osmótico estabelecidos nesse trabalho.

Quando analisamos os parâmetros fisiológicos osmolalidade, $\left[\mathrm{Cl}^{-}\right]$e $\left[\mathrm{Na}^{+}\right]$, observamos que todos são significamente afetados pelo fator espécie e as interações desse fator com os demais. A exceção foi a $\left[\mathrm{Na}^{+}\right]$, onde a interação espécie $\mathrm{X}$ tempo, e espécie $\mathrm{X}$ tempo $\mathrm{X}$ salinidade não foram significativas.

Ainda, quando analisamos os dados de expressão gênica, também fica comprovado estatisticamente que o fator espécie e suas interações com os demais fatores têm efeito sobre os resultados obtidos. De modo especial, vemos o efeito significativo da interação entre os três fatores: espécie $\mathrm{X}$ tempo $\mathrm{X}$ salinidade.

Como discutido anteriormente, ficou claro a influência da salinidade de experimentação e do tempo de exposição sobre os parâmetros fisiológicos e moleculares, porém agora, com essa análise de variância de 3 fatores, vemos que o fator espécie também determina as respostas, que são claramente diferentes entre Dilocarcinus pagei e Macrobrachium jelskii.

\subsection{Análise fenotípica das sequências de DNA obtidas para os ionotransportadores de interesse}

\subsubsection{Dilocarcinus pagei}

Quando analisamos os fenogramas gerados por similaridades com a sequência parcial da subunidade $\alpha$ da $\mathrm{Na}^{+} / \mathrm{K}^{+}$-ATPase (AF409119 - Figura 44A) e da subunidade B da $\mathrm{V}\left(\mathrm{H}^{+}\right)$ATPase (AF409118 - Figura 44B) de Dilocarcinus pagei, observamos que algumas das relações obtidas entre diferentes famílias de braquiúros são semelhantes às descritas por Tsang et al. (2014) (Figura 45), onde os autores avaliaram as relações entre as espécies em um contexto filogenético molecular, baseando-se em sequências parciais de 8 genes (6 
nucleares codificantes de proteínas e os mitocondriais rRNA 16S e 12S). A família Ocypodidae, por exemplo, forma grupo irmão com a família Grapsidae.

Já o fenograma obtido por similaridades com a sequência parcial do simportador $\mathrm{Na}^{+} / \mathrm{K}^{+} / 2 \mathrm{Cl}^{-}$(KX894795 - Figura 44C) também apresenta relações parecidas com a filogenia apresentada por Tsang et al. (2014) (Figura 45), pois a família Ocypodidae continue agrupada com a família Grapsidae e a família Portunidae forma grupo irmão com a família Trichodactylidae. No entanto, a família Beliidae não forma um grupo monofilético com Trichodactylidae.

Nesses 3 fenogramas (Figuras 44A, B e C), as espécies que sabidamente pertencem a uma mesma família ficam agrupadas.

Ainda, observamos que os habitats ocupados pelas diferentes espécies representadas são muito semelhantes dentre espécies de uma mesma família, o que provavelmente as aproxima em termos morfológicos e adaptativos. Também vale observar que as espécies pertencentes a outras infraordens que não Brachyura, como Palaemon pandaliformis e Macrobrachium olfersii que pertencem à infraordem Caridea (Figura 44C) formam grupos externos aos caranguejos braquiúros.

\section{A) $\mathrm{Na}^{+} / \mathrm{K}^{+}$-ATPase}

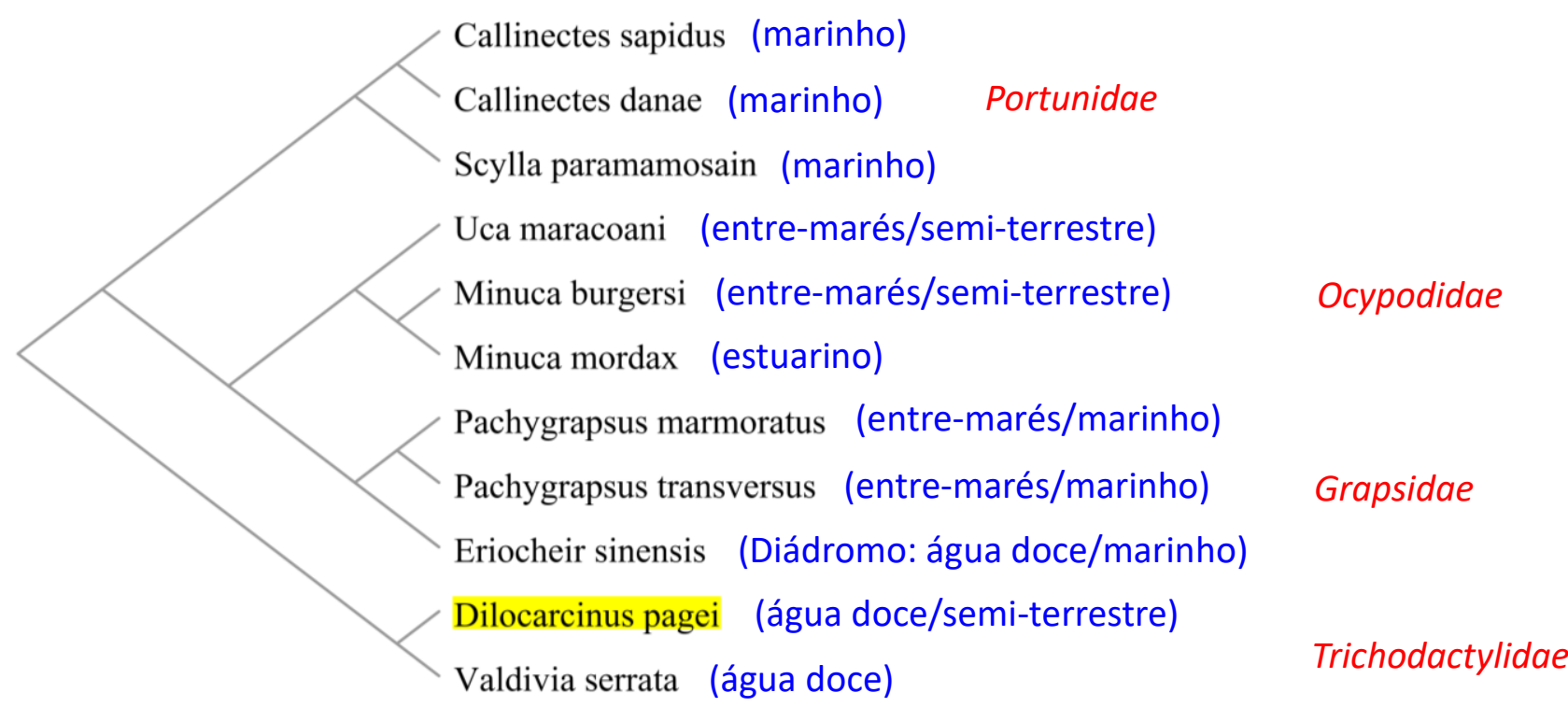




\section{B) $\mathrm{V}\left(\mathrm{H}^{+}\right)$-ATPase}

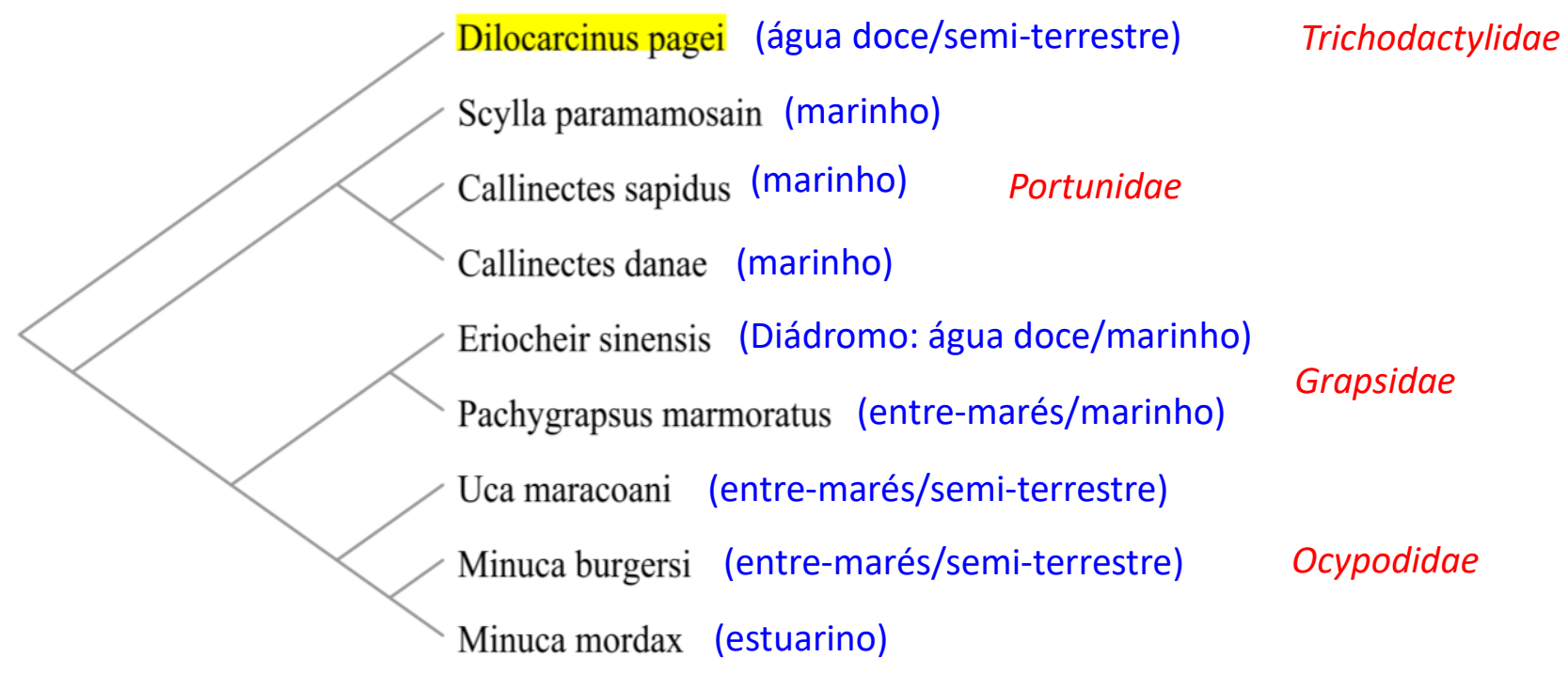

\section{C) $\mathrm{Na}^{+} / \mathrm{K}^{+} / 2 \mathrm{Cl}^{-}$}

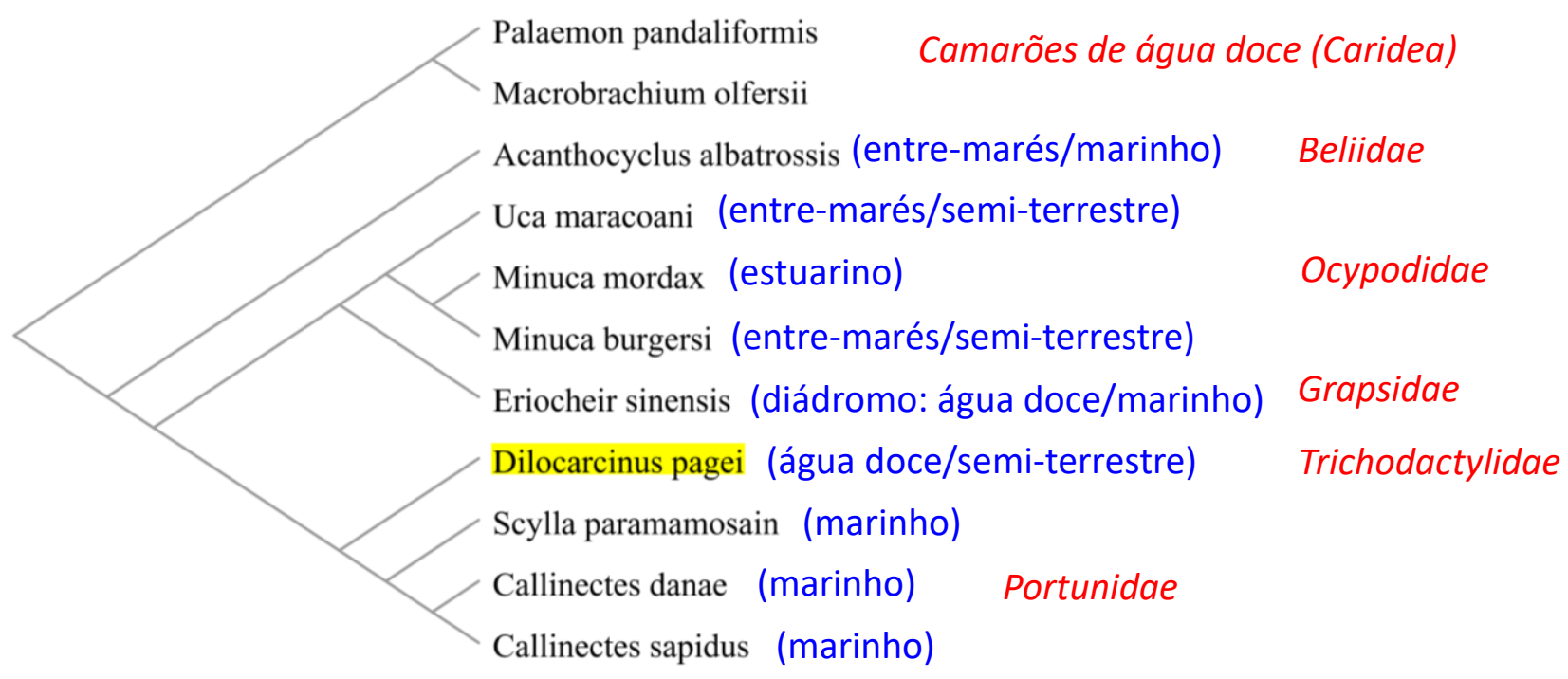

Figura 44. Fenogramas obtidos pela similaridade de sequências parciais de nucleotídeos de D. pagei e outras espécies. Fenogramas construídos a partir de sequências parciais que codificam A) a subunidade $\alpha$ da $\mathrm{Na}^{+} / \mathrm{K}^{+}-$ ATPase; B) a subunidade B da $\mathrm{V}\left(\mathrm{H}^{+}\right)$-ATPase; C) o simportador $\mathrm{Na}^{+} / \mathrm{K}^{+} / 2 \mathrm{Cl}^{-}$. Fizemos o alinhamento de sequências depositadas no GenBank, utilizando a ferramenta Blast. Para a construção dos fenogramas foi o utilizado o Método de Evolução Mínima. A classificação das famílias está baseada em Ng et al., 2008 e De Grave et al., 2009. 


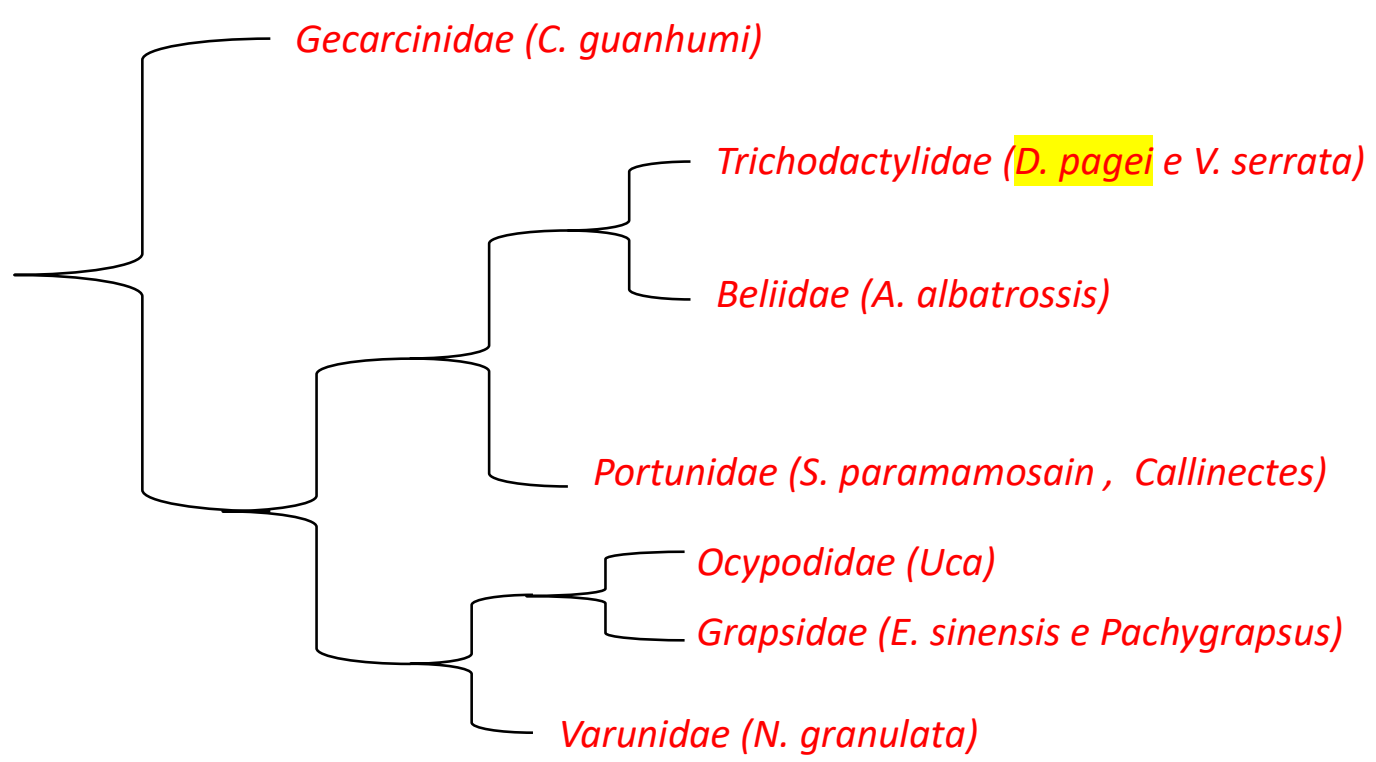

Figura 45. Filogenia de algumas famílias de caranguejos braquiúros. Essa filogenia retrata algumas das famílias cujas espécies foram apresentadas nos fenogramas da Figura 44 e é uma versão simplificada da descrita por Tsang et al. (2014) onde os autores avaliaram as relações entre as espécies em um contexto filogenético molecular, baseando-se em sequências parciais de 8 genes (6 nucleares codificantes de proteínas e os mitocondriais rRNA $16 \mathrm{~S}$ e 12S). Destacado em amarelo está a espécie D. pagei, um dos modelos desse estudo. A classificação das famílias está baseada em Ng et al., 2008 e De Grave et al., 2009.

\subsubsection{Macrobrachium jelskii}

Quando analisamos o fenograma gerado por similaridades com as sequências parciais da subunidade $\alpha$ da $\mathrm{Na}^{+} / \mathrm{K}^{+}$-ATPase de M. jelskii (MF615389 - Figura 46A), observamos que as espécies pertencentes a diferentes gêneros de camarões carídeos ficam bem separadas. Ainda, nesse fenograma e no construído a partir da sequência parcial do simportador $\mathrm{Na}^{+} / \mathrm{K}^{+} / 2 \mathrm{Cl}^{-}$(MG566061 - Figura 46C), as relações estabelecidas entre as diferentes espécies do gênero Macrobrachium que aparecem nas figuras são semelhantes às que aparecem na filogenia descrita por Pileggi et al. (2014) (Figura 47), onde os autores avaliaram as relações entre as espécies em um contexto filogenético molecular, baseando-se em sequências parciais dos genes 16S rRNA mitocondrial, 18S rRNA nuclear e COI mitocondrial.

O fenograma obtido por similaridades com a sequência parcial da subunidade $B$ da $\mathrm{V}\left(\mathrm{H}^{+}\right)$-ATPase (MG602347 - Figura 46B) apresenta relações um pouco mais distintas quando comparadas à filogenia apresentada, apesar de algumas relações se manterem, como o grupo monofilético formado por M. potiuna e M. brasiliense. 
Vale observar a variedade de diferentes habitats ocupados pelas diferentes espécies de camarões, inclusive dentro de um mesmo gênero. Também observar que nas Figuras 46B e C estão presentes algumas espécies de caranguejos, como Dilocarcinus pagei, que formam o grupo externo em relação aos camarões apresentados.

\section{A) $\mathrm{Na}^{+} / \mathrm{K}^{+}$-ATPase}

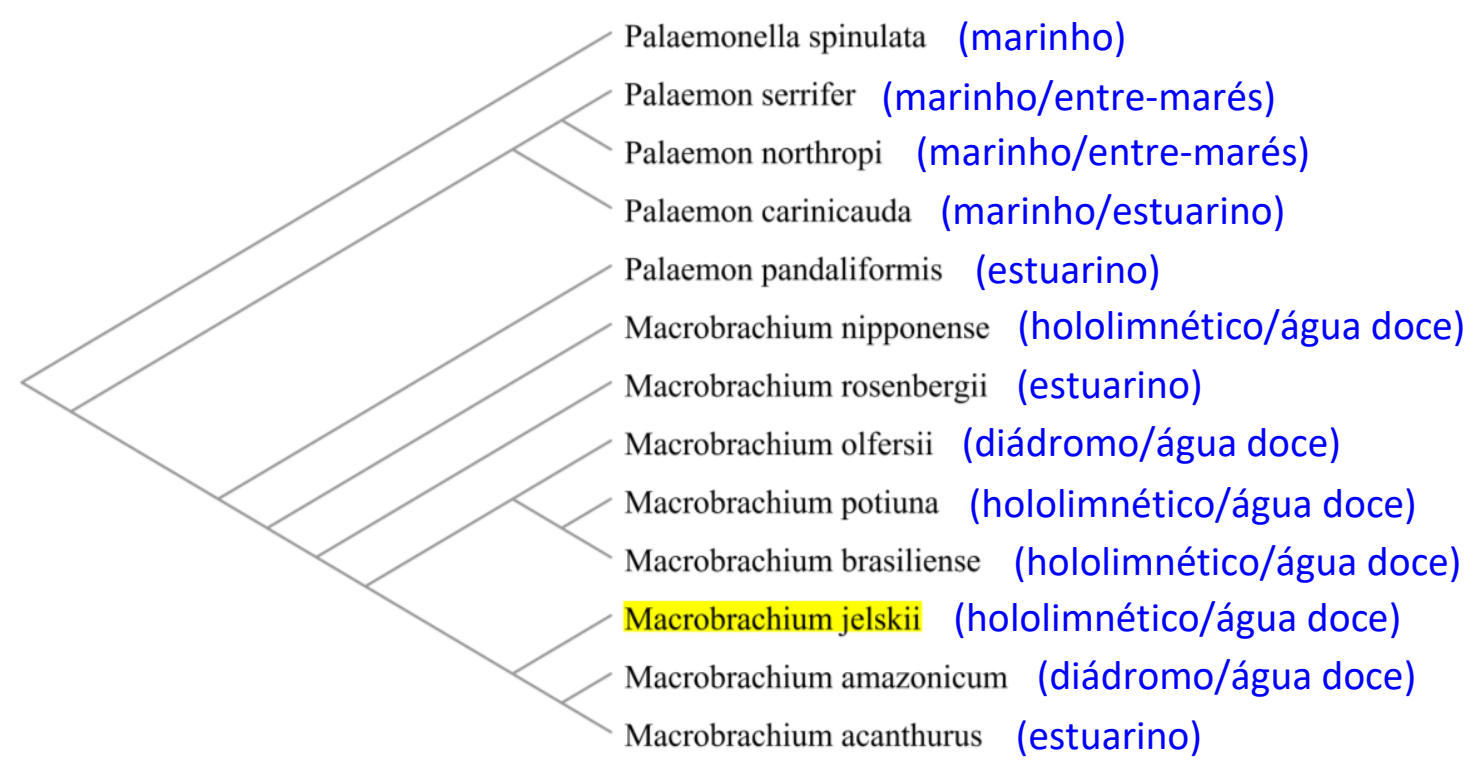

B) $\mathrm{V}\left(\mathbf{H}^{+}\right)$-ATPase

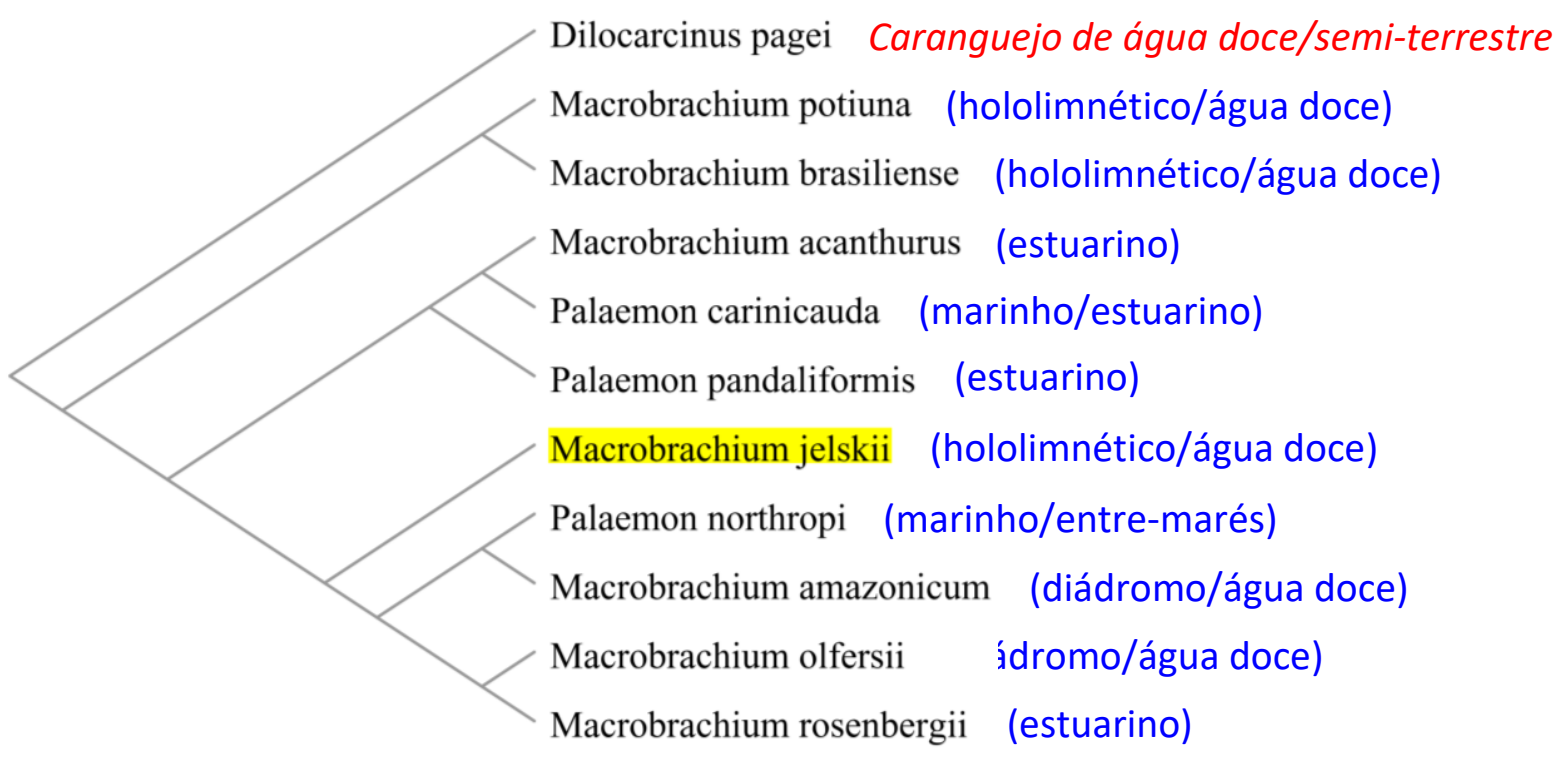




\section{C) $\mathrm{Na}^{+} / \mathrm{K}^{+} / 2 \mathrm{Cl}^{-}$}

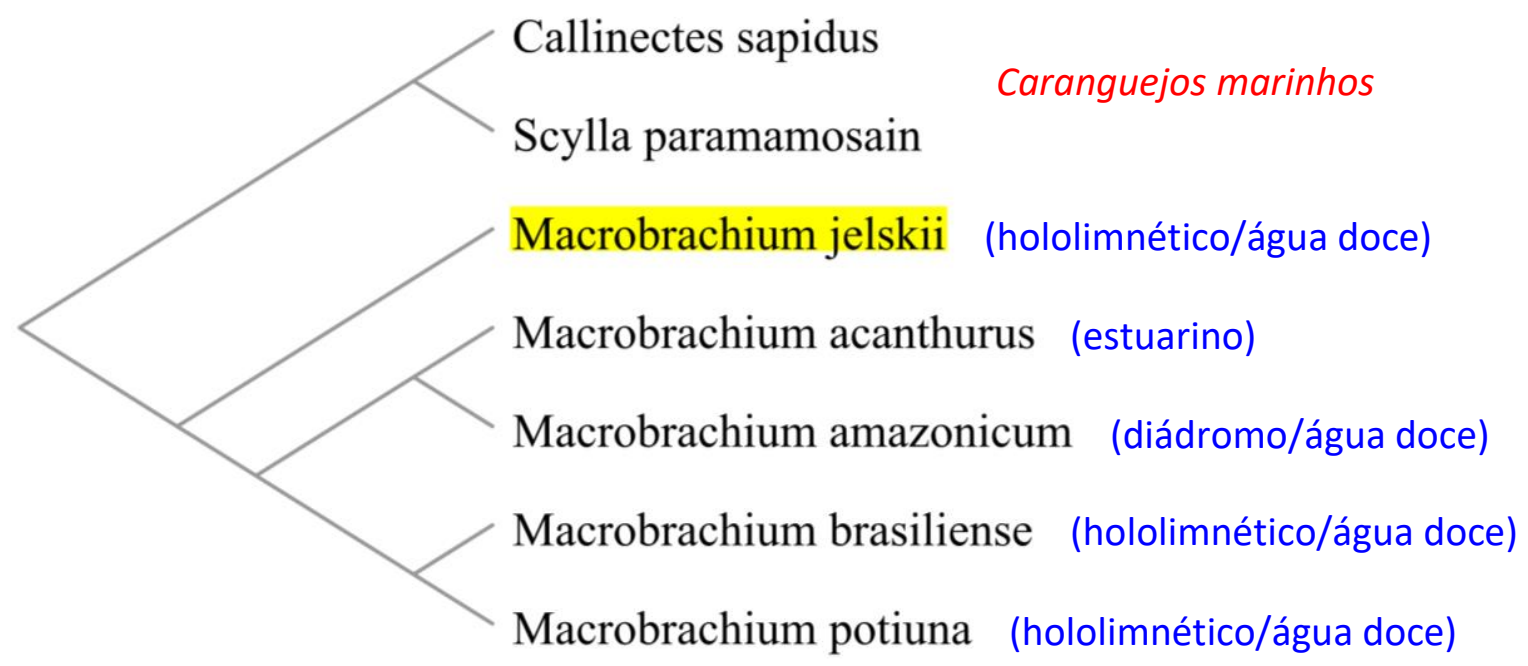

Figura 46. Fenogramas obtidos pela similaridade de sequências parciais de nucleotídeos de $M$. jelskii e outras espécies. Fenogramas construídos a partir de sequências parciais que codificam A) a subunidade $\alpha$ da $\mathrm{Na}^{+} / \mathrm{K}^{+}-$ ATPase; B) a subunidade B da $\mathrm{V}\left(\mathrm{H}^{+}\right)$-ATPase; C) o simportador $\mathrm{Na}^{+} / \mathrm{K}^{+} / 2 \mathrm{Cl}^{-}$. Fizemos o alinhamento de sequências depositadas no GenBank, utilizando a ferramenta Blast. Para a construção dos fenogramas foi o utilizado o Método de Evolução Mínima.

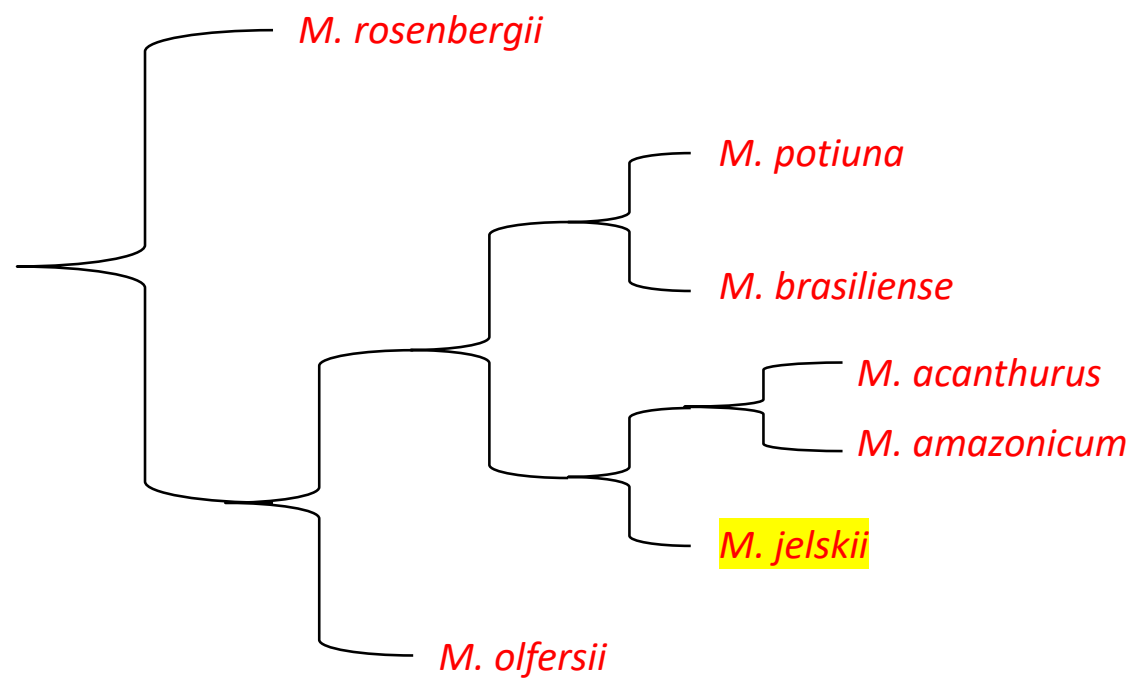

Figura 47. Filogenia de algumas espécies de camarões do gênero Macrobrachium. Essa filogenia retrata algumas das espécies que foram apresentadas nos fenogramas da Figura 46 e é uma versão simplificada da descrita por Pileggi et al. (2014), onde os autores avaliaram as relações entre as espécies em um contexto filogenético molecular, baseando-se em sequências parciais dos genes 16S rRNA mitocondrial, 18S rRNA nuclear e COI mitocondrial. Destacado em amarelo está a espécie M. jelskii, um dos modelos desse estudo.

As diferenças encontradas entre as sequências de DNA não necessariamente refletem diferenças entre as sequências de aminoácidos encontrados nas proteínas que tais genes 
expressam, como em casos de mutações silenciosas e também pelo fato de diferentes códons poderem determinar os mesmos aminoácidos (código genético degenerado).

Porém, embora bastante plausíveis, esses achados evidenciam o quanto as divergências entre as sequências de nucleotídeos refletem o processo evolutivo marcando o distanciamento entre as espécies, gêneros, famílias e assim por diante. Ainda, embora saibamos que as informações contidas nos fenogramas das Figuras 44 e 46 não reflitam aspectos evolutivos, fica evidente o quanto as relações filogenéticas são complexas e englobam muitos aspectos para serem inferidas. Apesar das sequências utilizadas para a construção dos fenogramas serem no mínimo 69\% semelhantes às sequências de interesse, e isso considerando as espécies utilizadas como grupo externo, muitas dessas sequências correspondem a espécies filogeneticamente bem distantes, algumas vezes de diferentes infraordens dentro de Decapoda.

Além disso, apesar de muitas espécies viverem em habitats parecidos, tendo desenvolvido adaptações que permitem enfrentar os mesmos desafios, os mecanismos e respostas para a invasão dos crustáceos em água doce são divergentes, como apresentado nesse trabalho, em referência à osmorregulação de D. pagei e M. jelskii.

Dessa forma, esse estudo apoia os indícios de que os diferentes mecanismos osmorregulatórios das espécies aqui abordadas provavelmente são características conservadas originárias de um antigo ancestral comum, pois são estruturalmente formados pelos mesmos ionotransportadores de membrana e tipos celulares. No entanto, embora essas espécies sejam filogeneticamente muito distantes dentro do grupo dos crustáceos, as diferenças marcantes entre os mecanismos osmorregulatórios provavelmente refletem eventos independentes de invasão da água doce pelos caranguejos braquiúros e pelos camarões carídeos. Os achados apresentados aumentam o conhecimento acerca da biologia molecular e fisiologia dos mecanismos osmorregulatórios em crustáceos hololimnéticos, como é o caso do caranguejo Dilocarcinus pagei e do camarão Macrobrachium jelskii. Os dados obtidos nas análises de expressão gênica claramente se revelam subjacentes aos mecanismos osmorregulatórios desenvolvidos, permitindo a ocupação do ambiente de água doce por ambas as espécies aqui estudadas. 
Conclusões 


\section{Conclusões}

1) Embora as duas espécies sejam filogeneticamente muito distantes dentro do grupo Decapoda, as diferenças marcantes entre os mecanismos osmorregulatórios provavelmente refletem eventos independentes de invasão da água doce pelos caranguejos braquiúros e pelos camarões carídeos.

2) D. pagei é um habitante de água doce mais antigo ( $\approx 130$ milhões de anos) que espécies do gênero Macrobrachium ( $\approx 30$ milhões de anos) e isso pode refletir o maior poder hiperregulador desse caranguejo e maior poder hiporregulador de $M$. jelskii ( $\approx 22$ milhões de anos).

3) A expressão dos genes aqui avaliados claramente se revela subjacente aos mecanismos osmorregulatórios desenvolvidos, permitindo a ocupação do ambiente de água doce por ambas as espécies aqui estudadas.

4) Os achados apresentados aumentam o conhecimento acerca dos mecanismos osmorregulatórios, sob os aspectos fisiológicos e moleculares, nos dois crustáceos hololimnéticos, o caranguejo Dilocarcinus pagei e o camarão Macrobrachium jelskii. 
Bibliografia 


\section{Bibliografia}

Ahearn GA, Duerr JM, Zhuang Z, Brown RJ, Aslamkhan A, Killebrew DA, 1999. Ion transport processes of crustacean epithelial cells. Physiol Biochem Zool 72, 1-18.

Altschul SF, Gish W, Miller W, Myers EW, Lipman DJ, 1990. Basic local alignment search tool. $J$ Mol Biol 215, 403-410.

Ashelby CW, Page TJ, De Grave S, Hughes JM, Johnson ML, 2012. Regional scale speciation reveals multiple invasions of freshwater in Palaemoninae (Decapoda). Zool Scripta 41, 293306.

Augusto A, Greene LJ, Laure HJ, McNamara JC, 2007a. The ontogeny of isosmotic intracellular regulation in the diadromous, freshwater palaemonid shrimps, Macrobrachium amazonicum and M. olfersii (Crustacea, Decapoda). J Crust Biol 27, 626-634.

Augusto A, Greene LJ, Laure HJ, McNamara JC, 2007b. Adaptive shifts in osmoregulatory strategy and the invasion of freshwater by brachyuran crabs: evidence from Dilocarcinus pagei (Trichodactylidae). J Exp Zool 307A, 688-698.

Augusto A, 2005. A invasão da água doce pelos crustáceos: o papel dos processos osmorregulatórios. Tese de Doutorado. Faculdade de Filosofia, Ciências e Letras de Ribeirão Preto, Universidade de São Paulo, Ribeirão Preto, Brasil.

Augusto A, Pinheiro AS, Greene LJ, Laure HJ, McNamara JC, 2009. Evolutionary transition to freshwater by ancestral marine palaemonids: evidence from osmoregulation in a tide pool shrimp. Aquatic Biol 7, 113-122.

Barnes DB, 1990. Zoologia dos Invertebrados. 4ª edição. Editora Roca, São Paulo, 1177 p.

Barros-Alves SP, Almeida AC, Fransozo V, Alves DFR, Silva JC, Cobo VJ, 2012. Population biology of the shrimp Macrobrachium jelskii (Miers, 1778) (Decapoda, Palaemonoidea) at the Grande River at northwest of the state of Minas Gerais, Brazil. Acta Limnol Bras 24, 266-275.

Begon M, Townsend CR, Harper JL, 2007. Ecologia de Indivíduos a Ecossistemas. $4^{\mathrm{a}}$ edição. Artmed, Porto Alegre, $752 \mathrm{p}$.

Belli NM, Faleiros RO, Firmino KCS, Masui D, Leone FA, McNamara JC, Furriel R, 2009. $\mathrm{Na}^{+}, \mathrm{K}^{+}$- ATPase activity and epithelial interfaces in gills of the freshwater shrimp Macrobrachium amazonicum (Decapoda, Palaemonidae). Comp Biochem Physiol 152A, 431439.

Boos H, GB Buckup, L Buckup, PB Araujo, C Magalhães, MP Almerão, RA Santos, FL Mantelatto. 2012. Checklist of the Crustacea from the state of Santa Catarina, Brazil. Check List 8(6), 1020-1046.

Boudour-Boucheker N, Boulo V, Charmantier- Daures M, Grousset E, Anger K, Charmantier G, Lorin-Nebel C, 2014. Differential distribution of V-type H+-ATPase and $\mathrm{Na}^{+} / \mathrm{K}^{+}$-ATPase in the branchial chamber of the palaemonid shrimp Macrobrachium amazonicum. Cell Tissue Res 357, 195-206.

Chamczynski P, Sacchi N, 1987. Single step method of RNA isolation by acid guanidinium thiocyanate-phenol-chloroform extraction. Anal Biochem 162, 156-159.

Charmantier G, Charmantier-Daures M, Towle D, 2009. Osmotic and ionic regulation in aquatic arthropods. In: Evans DH, editor. Osmotic and ionic regulation: Cells and animals. CRC Press, Boca Raton, 165-230.

Chen Z, Pottosin II, Cuin TA, Fuglsang AT, Tester M, Jha D, Zepeda-Jazo I, Zhou M, Palmgren MG, Newman IA, Shabala S, 2007. Root plasma membrane transporters controlling $\mathrm{K}^{+} / \mathrm{Na}^{+}$ homeostasis in saltstressed barley. Plant Physiol 145, 1714-1725.

Collins PA, Giri F, Williner, 2011. Biogeography of the freshwater decapods in the La Plata basin, South America. J Crust Biol 31, 179-191. 
Corotto FS, Holliday CW, 1996. Branchial NaK-ATPase and osmoregulation in the purple shore crab Hemigrapsus nudus (Dana). Comp Biochem Physiol 113A, 361-368.

De Grave S, Pentcheff ND, Ahyong ST, Chan T-Y, Crandall KA, Dworschak PC, Felder DL, Feldmann RM, Fransen CHJM, Goulding LYD, Lemaitre R, Low MEY, Martin JW, Ng PKL, Schweitzer CE, Tan SH, Tshudy D, Wetzer R, 2009. A classification of living and fossil genera of decapod crustaceans. Raffles Bull Zool Suppl 21, 1-109.

Evans DH, 2009. Osmotic and ionic regulation: Cells and animals. CRC Press, Boca Raton, 606 p.

Faleiros RO, Furriel RPM, McNamara JC, 2017. Transcriptional, translational and systemic alterations during the time course of osmoregulatory acclimation in two palaemonid shrimps from distinct osmotic niches. Comp Biochem Physiol 212A, 97-106.

Faleiros RO, Goldman MHS, Furriel RPM, McNamara JC, 2010. Differential adjustment in gill $\mathrm{Na}^{+} / \mathrm{K}^{+}$- and V-ATPase activities and transporter mRNA expression during osmoregulatory acclimation in the cinnamon shrimp Macrobrachium amazonicum (Decapoda, Palaemonidae). J Exp Biol 213, 3894-3905.

Faria SC, Provete DB, Thurman CL, McNamara JC, 2017. Phylogenetic patterns and the adaptive evolution of osmoregulation in fiddler crabs (Brachyura, Uca). PLoS ONE 12(2), 1-19.

Faria SC, Silva AA, McNamara JC, 2011. Intra- and extracellular osmotic regulation in the hololimnetic Caridea and Anomura: a phylogenetic perspective on the conquest of fresh water by the decapod Crustacea. J Comp Physiol B: Biochem Systemic Environ Physiol 181, 175186.

Finney DJ, 1952. Probit analysis: a statistical treatment ofthe sigmoid response carve. Cambridge University Press, Cambridge, 318 p.

Firmino KC, Faleiros RO, Masui DC, McNamara JC, Furriel RP, 2011. Short- and long-term, salinity-induced modulation of V-ATPase activity in the posterior gills of the true freshwater crab, Dilocarcinus pagei (Brachyura, Trichodactylidae). Comp Biochem Physiol B Biochem Mol Biol. 160(1), 24-31.

Foster C, Amado EM, Souza MM, Freire CA, 2010. Do osmoregulators have lower capacity of muscle water regulation than osmoconformers? A study on decapod crustaceans. J Exp Zool 313A, 80-94.

França JL, Pinto MR, Lucena MN, Garçon DP, Valenti WC, McNamara JC, Leone FA, 2013. Subcellular localization and kinetic characterization of a gill $(\mathrm{Na}+\mathrm{K}+)$-ATPase from the giant freshwater prawn Macrobrachium rosenbergii. J Membr Biol 246(7), 529-43.

Freire CA, Cavassin F, Rodrigues EN, Torres AH, McNamara JC, 2003. Adaptive patterns of osmotic and ionic regulation, and the invasion of fresh water by the palaemonid shrimps. Comp Biochem Physiol 136A, 771-778.

Freire CA, Onken H, McNamara JC, 2008a. A structure-function analysis of ion transport in crustacean gills and excretory organs. Comp Biochem Physiol 151(3), 272-304.

Freire CA, Amado EM, Souza LR, Veiga, MPT, Vitule JRS, Souza MM, Prodocimo V, 2008 b. Muscle water control in crustaceans and fishes as a function of habitat, osmoregulatory capacity, and degree of eurihalinity. Comp Biochem Physiol A 149, 435-446.

Freire CA, Maraschi AC, Lara AF, Amado EM, Prodocimo V, 2018. Late rise in hemolymph osmolality in Macrobrachium acanthurus (diadromous freshwater shrimp) exposed to brackish water: Early reduction in branchial $\mathrm{Na}^{+} / \mathrm{K}^{+}$pump activity but stable muscle HSP70 expression. Comp Biochem Physiol 216B, 69-74.

Freire CA, McNamara JC, 1995. Fine structure of the gills of the fresh-water shrimp Macrobrachium olfersii (Decapoda): effect of acclimation to high salinity medium and evidence for involvement of the lamellar septum in ion uptake. ln: Crustacean Society, editor. J Crustacean Biol 15(1), 103-116. 
Freire CA, Souza-Bastos LR, Amado EM, Prodocimo V, Souza MM, 2013. Regulation of muscle hydration upon hypo- or hyper-osmotic shocks: differences related to invasion of the freshwater habitat by decapod crustaceans. J Exp Zool A Ecol Genet Physiol 319(6), 297-309.

Furriel RPM, Firmino K, Masui DS, Faleiros RO, Torres AH Jr, McNamara JC, 2010. Structural and biochemical correlates of $\mathrm{Na}^{+} / \mathrm{K}^{+}$-ATPase driven ion transport in posterior gills of the true freshwater crab, Dilocarcinus pagei (Decapoda, Trichodactylidae). J Exp Zool 313A, 508523.

Genovese G, Ortiz N, Urcola MR, Luquet CM, 2005. Possible role of carbonic anhydrase, V- $\mathrm{H}^{+}-$ ATPase, and $\mathrm{Cl}^{-} / \mathrm{HCO}_{3}{ }^{-}$exchanger in electrogenic ion transport across the gills of the euryhaline crab Chasmagnathus granulatus. Comp Biochem Physiol 142A, 362-369.

Hall TA, 1999. BioEdit: a user-friendly biological sequence alignment editor and analysis program for Windows 95/98/NT. Nucl Acids Symp Ser 41, 95-98.

Harris RR, Aladin NV, 1997. The Ecophysiology of Osmoregulation in Crustacea. In: Hazon N, Eddy FB, Flik G, editors. Ionic Regulation in Animals: A Tribute to Professor W.T.W. Potts. Springer, Berlin, Heidelberg, 204 p.

Havird JC, Henry RP, Wilson AE, 2013. Altered expression of $\mathrm{Na}(+) / \mathrm{K}(+)$-ATPase and other osmoregulatory genes in the gills of euryhaline animals in response to salinity transfer: a meta-analysis of 59 quantitative PCR studies over 10 years. Comp Biochem Physiol Part D Genomics Proteomics 8(2),131-140.

Henry RP, Lucu C, Onken H, Weihrauch D, 2012. Multiple functions of the crustacean gill: osmotic/ionic regulation, acid-base balance, ammonia excretion, and bioaccumulation of toxic metals. Front Physiol 3, 431 p.

Holthuis LB, 1980. Shrimps and Prawns of the World: an Annotated Catalogue of Species of Interest to Fisheries. FAO Species Catalogue (Volume 1). FAO Fisheries Synopsis 125, 1261.

Kefford BJ, Papas PJ, Metzeling L, Nugegoda D, 2004. Do laboratory salinity tolerance of freshwater animals correspond with their field salinity? Environ Pollut 129, 355-362.

Kirschner LB, 1991. Water and ions. In: Prosser CL, editor. Environmental and metabolic animal physiology. Comparative animal physiology. Wiley-Liss, New York, 13-107 p.

Kirschner LB, 2004. The mechanism of sodium chloride uptake in hyperregulating aquatic animals. J Exp Biol 207, 1439-1452.

Klaus S, Yeo DCJ, Ahyong ST, 2011. Freshwater crab origins-laying Gondwana to rest. Zool Anz 250, 449-456.

Laemmli UK, 1970. Cleavage of structural proteins during the assembly of the head of bacteriophage T4. Nature 227(5259), 680-685.

Lee CE, Posavi M, Charmantier G, 2012. Rapid evolution of body fluid regulation following independent invasions into freshwater habitats. J Evol Biol 25, 625-633.

Livak KJ, Schmittgen TD, 2001. Analysis of relative gene expression data using real-time quantitative PCR and the $2^{-\Delta \Delta C T}$ Method. Methods 25, 402-408.

Leone FA, Furriel RPM, McNamara JC, Mantelatto FLM, Masui DC, Rezende LA, Gonçalves RR, Garçon DP, 2005. ( $\mathrm{Na}+, \mathrm{K}+$ )-ATPase from crustacean gill microsomes: a molecular marker to evaluate adaptation to biotopes of different salinity. Trends Comp Biochem Physiol $11,1-15$.

Lima AG, McNamara JC, Terra WB, 1997. Regulation of hemolymph osmolytes and gill $\mathrm{Na}^{+} / \mathrm{K}^{+}$-ATPase activities during acclimation to saline media in the freshwater shrimp Macrobrachium olfersii (Wiegmann, 1836) (Decapoda, Palaemonidae). J Exp Mar Biol Ecol 215, 81-91.

Lockwood APM. 1962. The osmoregulation of Crustacea. Biol Rev 37, 257-305.

Lockwood APM, Inman CBE, 1973. Water uptake and loss in relation to the salinity of the medium in the amphipod crustacean, Gammarus duebeni. J Exp Biol 58, 149-163. 
Lucena MN, Pinto MR, Garçon DP, McNamara JC, Leone FA, 2015. A kinetic characterization of the gill $\mathrm{V}(\mathrm{H}(+))$-ATPase in juvenile and adult Macrobrachium amazonicum, a diadromous palaemonid shrimp. Comp Biochem Physiol B Biochem Mol Biol 181, 15-25.

Lucu C, Towle DW, 2003. (Na+, K+)-ATPase in gills of aquatic Crustacea. Comp Biochem Physiol 135A, 195-214.

Luquet CM, Genovese G, Rosa GA, Pellerano GN, 2002. Ultrastructural changes in the gill epithelium of the crab Chasmagnathus granulatus (Decapoda: Grapsidae) in diluted and concentrated seawater. Mar Biol 141, 753-760.

Luquet CM, Weihrauch D, Senek M, Towle DW, 2005. Induction of branchial ion transporter mRNA expression during acclimation to salinity change in the euryhaline crab Chasmagnathus granulatus. J Exp Biol 208, 3627-3636.

Magalhães, C, 2000. Abbreviated larval development of Macrobrachium jelskii (Miers, 1877) (Crustacea: Decapoda: Palaemonidae) from the rio Solimões floodplain, Brazil, reared in the laboratory. Nauplius 8(1), 1-14.

Magalhães C, Bueno SLS, Bond-Buckup G, Valenti WC, Silva HLM, Kiyohara F, Mossolin EC, Rocha SS, 2005. Exotic species of freshwater decapod crustacean in the state of São Paulo, Brazil: records and possible causes of their introduction. Biodivers Conserv 14, 1929-1945.

Mantel LH, Farmer LL, 1983. Osmotic and ionic regulation. In: Bliss DE, editor. The biology of Crustacea: internal anatomy and physiological regulation. Academic Press, New York 5, 53159.

Maraschi AC, Freire CA, Prodocimo V, 2015. Immunocytochemical localization of V-H ${ }^{+}-$ ATPase, $\mathrm{Na}^{+} / \mathrm{K}^{+}$-ATPase, and carbonic anhydrase in gill lamellae of adult freshwater euryhaline shrimp Macrobrachium acanthurus (Decapoda, Palaemonidae). J Exp Zool 1-8.

Maraschi AC, 2018. O cotransportador $\mathrm{Na}^{+}, \mathrm{K}^{+}, 2 \mathrm{Cl}^{-}$e a secreção de cloreto branquial em camarões Palaemonidae (Decapoda, Crustacea): padrões moleculares, fisiológicos e evolutivos. Tese de Doutorado. Faculdade de Filosofia, Ciências e Letras de Ribeirão Preto, Universidade de São Paulo, Ribeirão Preto, Brasil.

Martinez CBR, Harris RR, Santos MCF, 1998. Transepithelial potential differences and sodium fluxes in isolated perfused gills of the mangrove crab Ucides cordatus. Comp Biochem Physiol 120A, 227-237.

Masui DC, Silva ECC, Mantelatto FLM, McNamara JC, Barrabin H, Scofano HM, Fontes CFL, Furriel RPM, Leone FA, 2008. The crustacean gill $\left(\mathrm{Na}^{+}, \mathrm{K}^{+}\right)$-ATPase: allosteric modulation of high- and low-affinity ATP binding sites by sodium and potassium. Arch Biochem Biophys 479, 139-144.

McNamara JC, Lima AG, 1997. The route of ion and water movements across the gill epithelium of the freshwater shrimp Macrobrachium olfersii (Decapoda, Palaemonidae): evidence from ultrastructural changes induced by acclimation to saline media. ln: Marine Biological Laboratory (Ed.). Biol Bull 192(2), 321-331.

McNamara JC, Torres AH, 1999. Ultracytochemical location of $\mathrm{Na}^{+} / \mathrm{K}^{+}$-ATPase activity and effects of high salinity acclimation in gill and renal epithelia of the freshwater shrimp Macrobrachium olfersii (Crustacea, Decapoda). J Exp Biol 284, 617-628.

McNamara JC, Faria SC, 2012. Evolution of osmoregulatory patterns and gill ion transport mechanisms in the decapod Crustacea: a review. J Comp Physiol B 8, 997-1014.

McNamara JC, Freire CA, Torres AHJ, Faria SC, 2015. The conquest of fresh water by the palaemonid shrimps: an evolutionary history scripted in the osmoregulatory epithelia of the gills and antennal glands. Biol J Linn Soc 114, 673-688.

Moreira, GS, McNamara JC, Shumway SE, Moreira OS, 1983. Osmoregulation and respiratory metabolism in Brazilian Macrobrachium (Decapoda, Palaemonidae). Comp Biochem Physiol 74, 57-62. 
Moshtaghi A, 2016. Identification and characterization of candidate genes influencing salinity tolerance in Macrobrachium australiense: a model for the molecular basis of colonization of low ionic environments. Tese de Doutorado. School of Earth, Environmental and Biological Science, Science and Engineering Faculty, Queensland University of Technology, Brisbane, Australia.

Mount DB, Delpire E, Gamba G, Hall AE, Poch E, Hoover RS, Hebert SC, 1998. The electroneutral cation-chloride cotransporters. J Exp Biol 201, 2091-2102.

Ng PKL, Guinot D, Davie PJF, 2008. Systema Brachyuorum: Part I. An annotated checklist of extant Brachyuran crabs of the world. Raffles Bull Zool Suppl 17, 1-286.

Oh DH, Lee SY, Bressan RA, Yun DJ, Bohnert HJ, 2010. Intracellular consequences of SOS1 deficiency during salt stress. J Exp Bot 61, 1205-1213.

Onken H, Graszynski K, Johannsen A, Putzenlechner M, Riestenpatt S, Schirmer C, Siebers D, Zeiske W, 1995. How to overcome osmotic stress? Marine crabs conquer freshwater. New insights from modern electrophysiology. Helgoländer Meeresunters 49, 715-725.

Onken H, Graszynski K, Zeiske W, 1991. $\mathrm{Na}^{+}$-independent, electrogenic $\mathrm{Cl}^{-}$uptake across the posterior gills of the Chinese crab (Eriocheir sinensis): voltage-clamp and microelectrode studies. J Comp Physiol 161B, 293-301.

Onken H, McNamara JC, 2002. Hyperosmoregulation in the red freshwater crab Dilocarcinus pagei (Brachyura, Trichodactylidae): structural and functional asymmetries of the posterior gills. J Exp Biol 205(2), 167-175.

Onken H, Putzenlechner M, 1995. A V-ATPase drives active, electrogenic and $\mathrm{Na}^{+}$-independent $\mathrm{Cl}^{-}$absorption across the gills of Eriocheir sinensis. J Exp Biol 198, 767-774.

Onken H, Riestenpatt S, 1998. NaCl absorption across split gill lamellae of hyperregulating crabs: transport mechanisms and their regulation. Comp Biochem Physiol 119A, 883-893.

Ottoni FP, Lezama, AQ, Triques ML, Fragoso-Moura EN, Lucas CCT, Barbosa FAR, 2011. Australoheros perdi, new species (Teleostei: Labroidei: Cichlidae) from the lacustrine region of the Doce River Valley, southeastern Brazil, with biological information. Vertebr Zool 61, 137-145.

Paller MS, 1994. Lateral mobility of Na,K-ATPase and membrane lipids in renal cells. Importance of cytoskeletal integrity. J Membr Biol 142, 127-135.

Péqueux A, 1995. Osmotic regulation in crustaceans. J Crust Biol 15, 1-60.

Pileggi LG, Magalhães C, Bond-Buckup G, Mantelatto FL, 2013. New records and extension of the known distribution of some freshwater shrimps in Brazil. Revista Mexicana de Biodiversidad 84, 563-574.

Pileggi LG, Rossi N, Wehrtmann IS, Mantelatto FL, 2013. Molecular perspective on the American transisthmian species of Macrobrachium (Caridea, Palaemonidae). ZooKeys 457, 109-131.

Pullikuth AK, Filippov V, Gill SS, 2003. Phylogeny and cloning of ion transporters in mosquitoes. J Exp Biol 206, 3857-3868.

Putzenlechner M, Onken H, Klein U, Graszynski K, 1992. Electrogenic $\mathrm{Cl}^{-}$uptake across the gill epithelium of Eriocheir sinensis: energized by a V-type ATPase? Verh Dtsch Zool Ges 85, 160.

Rahi ML, Amin S, Mather PB, Hurwood DA, 2017. Candidate genes that have facilitated freshwater adaptation by palaemonid prawns in the genus Macrobrachium: identification and expression validation in a model species (M. koombooloomba). J Heredity 2016, 1-9.

Randall D, Burggren W, French K, 1997. Eckert - Animal Physiology. Mechanisms and Adaptation. $4^{\mathrm{a}}$ edição. W. H. Freeman and Company, New York, 723 p.

Rea PA, Poole RJ, 1985. Proton-translocating inorganic pyrophosphatase in red beet (Beta vulgaris L.) tonoplast vesicles. Plant Physiol 77, 46-52. 
Rea PA, Poole RJ, 1993. Vacuolar $\mathrm{H}^{+}$-translocating pyrophosphatase. Annu Rev Plant Physiol Plant Mol Biol 44,157-180.

Riegel JA, 1959. Some aspects of osmoregulation in two species of sphaeromid isopod crustacea. Biological Bulletin 116(2), 272-284.

Ruppert EE, Barnes RD, 1994. Invertebrate zoology. 6 ${ }^{\text {a }}$ edição. Harcourt Brace College Publishers, Fort Worth, Texas, 1100 p.

Russell JM, 2000. Sodium-potassium-chloride cotransport. Physiol Rev 80, 211-276.

Rzhetsky A, Nei M, 1993. Theoretical Foundation of the Minimum-Evolution Method of Phylogenetic Inference. Mol Biol Evol 10(5), 1073-1095.

Sáez AG, Lozano E, Zaldívar-Riverón A, 2009. Evolutionary history of Na,K-ATPases and their osmoregulatory role. Genetica 136, 479-490.

Sanger F, Nicklen S, Coulson A, 1977. DNA sequencing with chain-terminating inhibitors. Proc Nat Acad Sci USA 74, 5463-5467.

Santos LCF, Belli NM, Augusto A, Masui DC, Leone FA, McNamara JC, Furriel RPM, 2007. Gill $\mathrm{Na}^{+}, \mathrm{K}^{+}$-ATPase in diadromous, freshwater palaemonid shrimps: Species-specific kinetic characteristics and $\alpha$-subunit expression. Comp Biochem Physiol 148A, 178-188.

Santos FH, McNamara JC, 1996. Neuroendocrine modulation of osmoregulatory parameters in the freshwater shrimp Macrobrachium Olfersii (Wiegmann) (Crustacea, Decapoda). Exp Mar Biol Ecol 206, 109-120.

Schales O \& Schales SS, 1941. A simple and accurate method for the determination of chloride in biological fluids. J Biol Chem 140, 879-884.

Schmidt-Nielsen K, 2002. Fisiologia Animal: adaptação e meio ambiente. $5^{\text {a }}$ edição. Livraria Santos Editora, São Paulo, 611 p.

Schneider CA, Rasband WS, Eliceiri KW, 2012. NIH Image to ImageJ: 25 years of image analysis. Nature methods 9(7), 671-675.

Schubart CD, Diesel R, Hedges SB, 1998. Rapid evolution to terrestrial life in Jamaican crabs. Nature 393, 363-365.

Schwanhäusser B, Busse D, Li N, Dittmar G, Schuchhardt J, Wolf J, Chen W, Selbach M, 2011. Global quantification of mammalian gene expression control. Nature 473(7347), 337-342.

Sharova LV, Sharov AA, Nedorezov T, Piao Y, Shaik N, Ko MS, 2009. Database for mRNA half-life of 19977 genes obtained by DNA microarray analysis of pluripotent and differentiating mouse embryonic stem cells. DNA Res 16(1), 45-58.

Shi HZ, Zhu JK, 2002. Regulation of expression of the vacuolar $\mathrm{Na}^{+} / \mathrm{H}^{+}$antiporter gene AtNHX1 by salt stress and abscisic acid. Plant Mol Biol 50, 543-550.

Silva P, Facanha AR, Tavares RM, Geros H, 2010. Role of tonoplast proton pumps and $\mathrm{Na}^{+} / \mathrm{H}^{+}$ antiport system in salt tolerance of Populus euphratica Oliv. J Plant Growth Regul 29, 23-34.

Soares, MRS, 2008. Biologia populacional de Macrobrachium jelskii (Crustacea, Decapoda, Palaemonidae) na represa de Três Marias e no rio São Francisco, MG, Brasil. Dissertação de Mestrado. Instituto de Biologia, Universidade Federal Rural do Rio de Janeiro, Rio de Janeiro, Brasil.

Taylor HH, Taylor EW, 1992. Gills and lungs: the exchange of gases and ions. In: Harrison FW, Humes AG, editors. Microscopic anatomy of invertebrates. Decapod Crustacea. Wiley, New York 10, 203-293.

Thornton B and Basu C, 2011. Real-time PCR (qPCR) primer design using free online software. Biochem Mol Biol Educ 39(2), 145-154.

Thurman CL, 2002. Osmoregulation in six sympatric fiddler crabs (genus Uca) from the northwestern Gulf of Mexico. Mar Ecol 23, 269-284.

Thurman C, 2003. Osmoregulation in fiddler crabs (Uca) from temperate Atlantic and Gulf of Mexico coasts of North America. Mar Biol 142, 77-92. 
Torres AH Jr, 2006. Um estudo eletrofisiológico e ultraestrutural do transporte iônico transepitelial em camarões e caranguejos (Crustacea, Decapoda). Tese de Doutorado. Faculdade de Filosofia, Ciências e Letras de Ribeirão Preto, Universidade de São Paulo, Ribeirão Preto, Brasil.

Towle DW, Kays WT, 1986. Basolateral localization of $\mathrm{Na}^{+} / \mathrm{K}^{+}$-ATPase in gill epithelium of two osmoregulating crabs, Callinectes sapidus and Carcinus maenas. J Exp Zool 239, 311-318.

Towle DW, Paulsen RS, Weihrauch D, Kordylewski M, Salvador C, Lignot JH, Pierrot, CS, 2001. $\mathrm{Na}^{+} / \mathrm{K}^{+}$-ATPase in gills of the blue crab Callinectes sapindus: cDNA sequencing and salinity-related expression of $\alpha$-subunit mRNA abd protein. J Exp Biol 204, 4005-4012.

Towle DW, Rushton ME, Heidysch D, Magnani JJ, Rose MJ, Amstutz A, Jordan MK, Shearer DW, Wu WS, 1997. Sodium/proton antiporter in the euryhaline crab Carcinus maenas: molecular cloning, expression and tissue distribution. J Exp Biol 200, 1003-1014.

Tsai JR, Lin HC, 2007. V-type $\mathrm{H}^{+}$-ATPase and $\mathrm{Na}^{+}, \mathrm{K}^{+}$-ATPase in the gills of 13 euryhaline crabs during salinity acclimation. $J$ Exp Biol 210, 620-627.

Tsang LM, Schubart CD, Ahyong ST, Lai JCY, Au EYC, Chan TY, Ng PKL, Chu KH, 2014. Evolutionary History of True Crabs (Crustacea: Decapoda: Brachyura) and the Origin of Freshwater Crabs. Mol Biol Evol 31(5), 1173-1187.

Van Horn J, Tolley SG, 2009. Acute response of the estuarine crab Eurypanopeus depressus to salinity and desiccation stress. J Crust Biol 29(4), 556-561.

Vera-Silva AL, Carvalho FL, Mantelatto FL, 2016. Distribution and genetic differentiation of Macrobrachium jelskii (Miers, 1877) (Natantia: Palaemonidae) in Brazil reveal evidence of non-natural introduction and cryptic allopatric speciation. J Crust Biol 36(3), 373-383.

Vogel C, Marcotte EM, 2012. Insights into the regulation of protein abundance from proteomic and transcriptomic analyses. Nat Rev Genet 13(4), 227-232.

Xue, ZY, Zhi DY, Xue GP, Zhang H, Zhao YX, Xia GM, 2004. Enhanced salt tolerance of transgenic wheat (Tritivum aestivum L.) expressing a vacuolar $\mathrm{Na}^{+} / \mathrm{H}^{+}$antiportergene with improved grain yields in saline soils in the field and a reduced level of leaf $\mathrm{Na}^{+}$. Plant Sci $167,849-859$.

Weihrauch D, McNamara JC, Towle DW, Onken H, 2004. Ion-motive ATPases and active, transbranchial $\mathrm{NaCl}$ uptake in the red freshwater crab, Dilocarcinus pagei (Decapoda Trichodactylidae). J Exp Biol 207, 4623-4631.

Weihrauch D, Towle DW, 2000. Sequência parcial do gene $\mathrm{Na}^{+} / \mathrm{K}^{+} / 2 \mathrm{Cl}^{-}$de Scylla paramamosain depositado no banco de dados GenBank sob número de acesso AF301160.

Weihrauch D, Ziegler A, Siebers D, Towle DW, 2001. Molecular characterization of V-type $\mathrm{H}^{+}$ATPase ( $\beta$-subunit) in gills of euryhaline crabs and its physiological role in osmoregulatory ion uptake. J Exp Biol 204, 25-37.

Weihrauch D, Ziegler A, Siebers D, Towle DW, 2002. Active ammonia excretion across the gills of the green shore crab Carcinus maenas: participation of $\mathrm{Na}^{+} / \mathrm{K}^{+}$-ATPase, $\mathrm{V}$-type $\mathrm{H}^{+}$ATPase and functional microtubules. J Exp Biol 205, 2765-2775.

Wheatly MG, Gao Y, 2004. Molecular biology of ion motive proteins in comparative models. $J$ Exp Biol 207, 3253-3263.

Willmer P, Stone G, Johnston I, 2005. Environmental physiology of animals. $2^{\text {a }}$ edição. Blackwell Publishing, Oxford, $754 \mathrm{p}$.

Wynn A, Shafer TH, Coblentz FE, 2004. Sequência completa do mRNA do gene que codifica a PRL10 de Callinectes sapidus, depositado no banco de dados Genbank sob número de acesso AY822650.

Yang Q, Chen ZZ, Zhou XF, Yin HB, Li X, Xin XF, Hong XH, Zhu JK, Gong ZZ, 2009. Overexpression of SOS (Salt Overly Sensitive) genes increases salt tolerance in transgenic Arabidopsis. Mol Plant 2, 22-31. 
Yang WK, Kang CK, Chen TY, Chang WB, Lee TH, 2011. Salinitydependent expression of the branchial $\mathrm{Na}^{+} / \mathrm{K}^{+} / 2 \mathrm{Cl}^{-}$cotransporter and $\mathrm{Na}^{+} / \mathrm{K}^{+}$-ATPase in the sailfin molly correlates with hypoosmoregulatory endurance. J Comp Physiol 181B, 953-964.

Zare S, Greenaway P, 1998. The effects of moulting and sodium depletion on sodium transport and activities of $\mathrm{Na}^{+} / \mathrm{K}^{+}$-ATPase, and V-ATPase in the freshwater crayfish Cherax destructor (Crustacea: Parastacidae). Comp Biochem Physiol 119A, 739-745. 